A comprehensive assessment of

\title{
AGRICULTURE IN LOWLANDS
}

\author{
of south Brazil
}

Characterization and comparison of current and alternative concepts
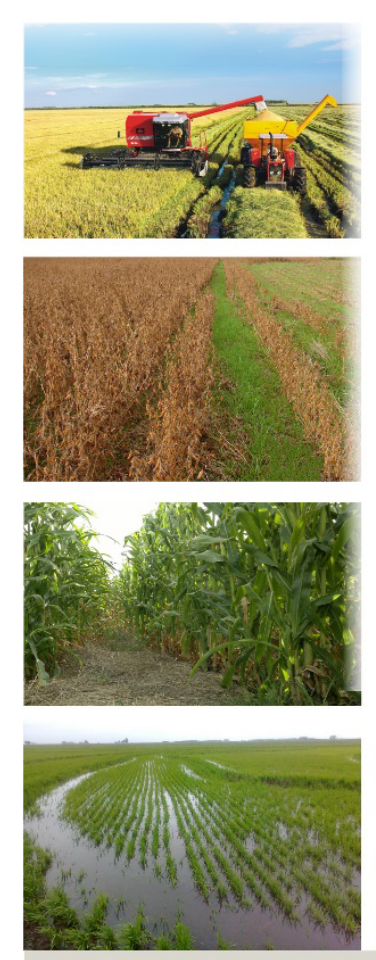

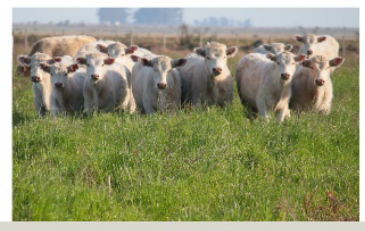

Giovani Theisen 

A comprehensive assessment of agriculture in lowlands of south Brazil: characterization and comparison of current and alternative concepts

Giovani Theisen 


\section{Thesis committee}

\section{Promotor}

Prof. Dr N.P.R. Anten

Professor of Crop and Weed Ecology

Wageningen University \& Research

\section{Co-promotor}

Dr Lammert Bastiaans

Associate professor, Centre for Crop System Analysis

Wageningen University \& Research

\section{Other members}

Prof. Dr P.W.G. Groot-Koerkamp, Wageningen University \& Research

Prof. Dr J. L. Lindquist, University of Nebraska, USA

Dr P. Reidsma, Wageningen University \& Research

Dr P.A.J. van Oort, Africa Rice Center, Côte d'Ivoire

This research was conducted under the auspices of the C.T. de Wit Graduate School for Production Ecology and Resource Conservation 


\section{A comprehensive assessment of agriculture in lowlands of south Brazil: characterization and comparison of current and alternative concepts}

\section{Giovani Theisen}

\section{Thesis}

submitted in fulfilment of the requirements for the degree of doctor at Wageningen University by the authority of the Rector Magnificus

Prof. Dr A.P.J. Mol, in the presence of the

Thesis Committee appointed by the Academic Board to be defended in public on Wednesday 18 October 2017 at 4 p.m. in the Aula. 
Giovani Theisen

A comprehensive assessment of agriculture in lowlands of south Brazil: characterization and comparison of current and alternative concepts

234 pages.

$\mathrm{PhD}$ thesis, Wageningen University, Wageningen, Netherlands (2017)

With references, with summary in English and Portuguese

ISBN: 978-94-6343-638-0

DOI: $10.18174 / 419841$ 


\section{Abstract}

Agriculture in the lowlands of south Brazil is of strategic importance at the national level, since it supplies around $80 \%$ of the rice consumed by the Brazilian population. In Rio Grande do Sul, the southernmost state in Brazil, three million hectares of lowlands are ready for grain-based agriculture. Of this area, about half is fallow, partly used for cattle grazing, and irrigated rice is the predominant crop, cultivated annually on 1.1 million ha. The remaining area is used for soybean and other crops. The predominant cropping system is a combination of irrigated rice and cattle. Over the last decades, rice yields have steadily increased, but this rise in yield level has to a large extent been obtained at the expense of a continuously higher use of external inputs. The recent introduction of soybean in rotation with rice has partially improved the system, but in most areas the situation is becoming incompatible with the modern demands for sustainability. This thesis presents a long-term study (2006-2015) of five cropping systems for lowlands. Next to monocrop rice and two rice-soybean rotations conducted in either conventional or minimum tillage, the experiment contained two novel systems based on large ridges, on which soybean and maize were combined with either cover crops or crop-livestock integration in winter. In these last systems, 8-m-wide ridges were built to avoid flooding, thus allowing for diversification of cash crops and the cultivation of cover crops or pastures in winter time, as well as the use of no-tillage. All systems were evaluated at process-level, including soil preparation, seeding, plant nutrition, pest management, irrigation, harvesting, transport and cattle management, as well as regarding their performance for the different dimensions of sustainability, particularly environment, land productivity, economics, energy-use and labour. Next to system assessment, two additional experiments were conducted for the evaluation of two specific technologies for soil management in these areas. Crop livestock integration on the ridge-based system offered the best balance between food production, environmental impact and economics. This system is well suited to be used in fields that are kept fallow, thereby enlarging the agricultural productivity of the lowlands. The additional experiments revealed that a knife-roller can successfully substitute plough-and-harrow for soil preparation after rice harvest, and that germination of weed seeds can be reduced if crop seeding is conducted at a lower speed or using a no-tillage seeder equipped with an improved cutting mechanism. Overall the results show that by using alternative cropping systems that allow for diversification and new methods of field management it is possible to simultaneously attain a larger agricultural production and improved sustainability in the lowlands.

Keywords: cropping system, indicator, intensification, management, sustainability, wetlands. 



\section{Table of contents}

Chapter 1 General introduction 1

Chapter 2 The birth of a new cropping system: towards sustainability in the sub-tropical lowland agriculture 47

Chapter 3 Use of a multi-criteria approach to evaluate agricultural cropping systems in lowlands

Chapter 4 A knife-roller effectively substitutes soil preparation by plough-andharrow in lowland production systems

Chapter 5 Low disturbance and low speed seeding suppress weeds in no-tillage soybean

Chapter 6 General Discussion

Supplementary Information 205

$\begin{array}{ll}\text { Summary } & 215\end{array}$

$\begin{array}{ll}\text { Resumo } & 221\end{array}$

$\begin{array}{lr}\text { Acknowledgments } & 227\end{array}$

PE \& RC Training and Education Statement 229

List of publications $\quad 231$

About the author 233

$\begin{array}{ll}\text { Funding } & 234\end{array}$ 



\section{Chapter 1}

General Introduction 
The temperate South-American rangelands...

Far as the eye can reach are swamps, swamps, and more swamps, a sea of waving pampagrass (Álvar Nuñes, Spanish conqueror, 1545) ${ }^{1}$

Scarcely anything which travellers have written about its extreme flatness, can be considered as exaggeration (Charles Darwin, 1839) ${ }^{2}$

The finest breeds of sheep, cattle and hogs are raised here on these flat Prairie lands (Walt Disney, 1941) ${ }^{3}$

The new agricultural frontier in South Brazil (Zero Hora, 2014) ${ }^{4}$
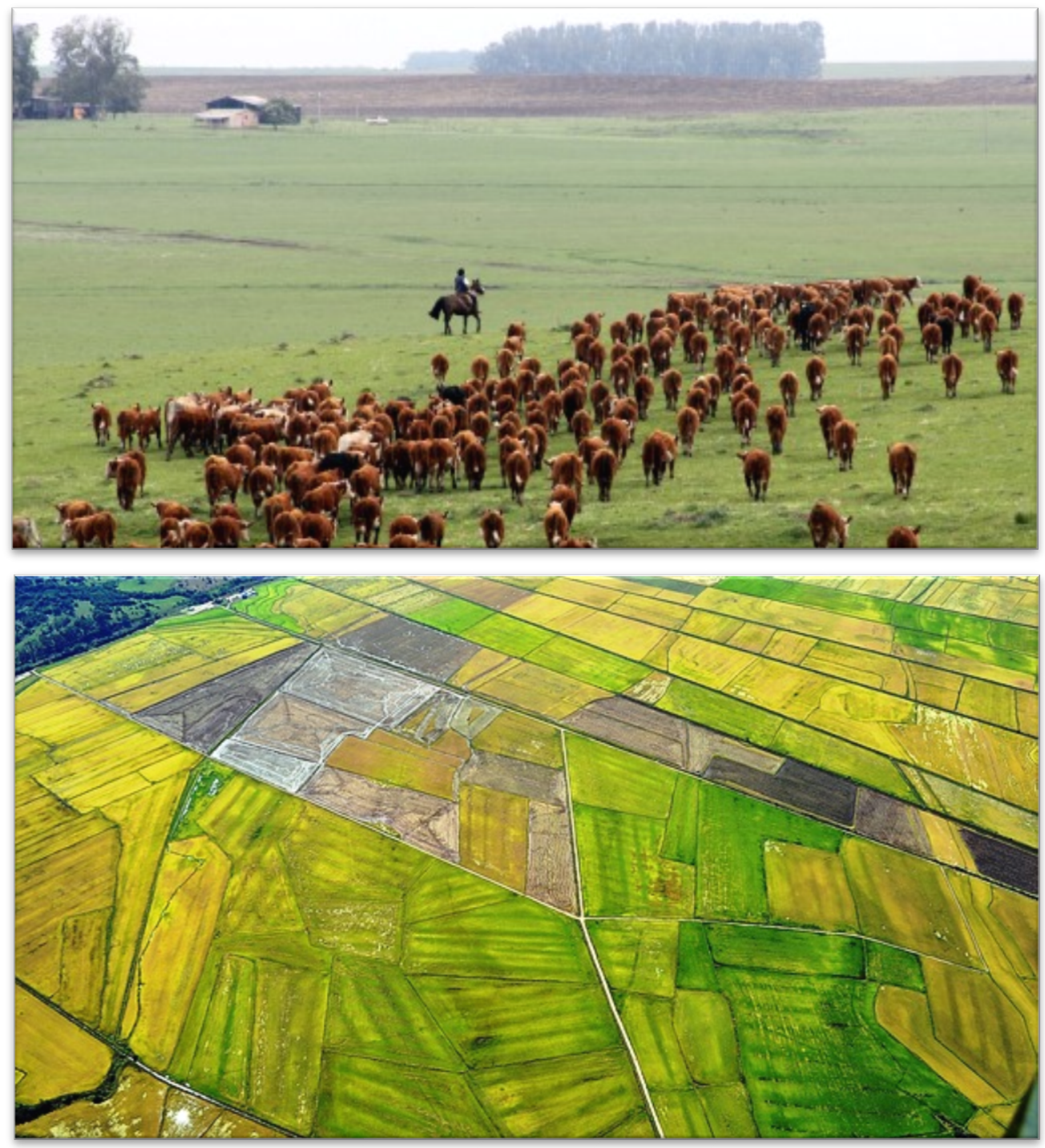

Free range livestock and irrigated rice: typical sceneries of southern Brazilian rangelands.

\footnotetext{
${ }^{1}$ Cunninghame Graham. A vanished arcadia, 1901.

${ }^{2}$ Darwin, Charles Robert. The voyage of the Beagle, 1845.

${ }^{3}$ A Walt Disney Production. South of the Border with Disney, documentary film, 1952.

${ }^{4}$ Zero Hora (newspaper), Porto Alegre, Brazil, 04 May 2014.
} 


\subsection{General overview}

\section{The extreme south of Brazil - the Pampas}

The Pampas ${ }^{5}$ of South America is essentially a grassland biome. It is made up of flat and uniform plains that cover an area of around 777,000 square kilometres, extending from the Atlantic Ocean towards the Andes Mountains. The Pampas is primarily found in Argentina and extends into the whole of Uruguay and south Brazil (Figure 1). In Brazil, this biome is located in Rio Grande do Sul (RS) state, in the extreme south of the country. The old grasslands, which are also known as the Uruguayan Savannah and Pastizales del Río de La Plata, are composed of a meadow mosaic with ten distinct ecological zones (Hasenack et al., 2010). In the RS, the biome spreads over $178,243 \mathrm{~km}^{2}$, and is composed of natural vegetation (41\%), surface fresh water (10\%) and anthropized agricultural fields, which constitute $49 \%$ of the area (PROBIO, 2007).

Although only $11.7 \%$ of the Pampas in Brazil remains free of anthropogenic uses (PROBIO, 2007) the biome still preserves a substantial part of its original aspects, such as a rich biodiversity. The Pampas is home to about 3000 vascular plant species, of which around 400 are grasses, 385 species of birds and 90 terrestrial mammal species (Bilenca \& Miñarro, 2004; Pillar et al., 2009). The biome is characterized by a high potential for forage production, which benefits herbivorous animals (Carvalho \& Batello, 2009). In fact, cattle production has impacted the landscape and the culture of this region since the settlements from Spanish Jesuits in the early $16^{\text {th }}$ century, who brought the first herds of cattle (Bos taurus) and horses from Europe. Living free in these grass-riche rangelands, cattle attained an estimated population of 48 million heads (i.e., slightly over 60 heads $/ \mathrm{km}^{2}$ ) in the early 1700's (Cruz \& Guadagnin, 2012).

The famous English naturalist Charles Darwin, who explored the region in 1832, registered "countless herds of cattle, sheep and horses", "a uniform layer of fine green turf", and "boundless plains", to describe the landscape of the Pampas in his book The voyage of the Beagle, published in 1845 (Darwin, 1845). Currently the Pampas provide feed for 43 million heads of cattle and 14 million sheep (Modernel et al., 2016), from which 9 million cattle and 3.9 million sheep are located in the Brazilian part of the biome. Consequently, livestock

\footnotetext{
${ }^{5}$ From Quechua pampa, meaning "uniform and plain". Quechua is an indigenous language from ancient South America, known for being the main language of the Inca Empire.
} 
production was, and still is, one of most important activities of the primary sector of the Pampas in South America; the entire area supplies around $8 \%$ of all exports of bovine meat in the world (USDA, 2017).

Even with the recognized quality and a large productive potential, the efficiency of cattle production in the south Brazilian rangelands can be improved, in the opinion of experts (Barcellos et al., 2011). Many ranchers in RS have managed the Pampas grasslands with practices that caused overgrazing, low productivity, and low financial income (Nabinger et al., 2009; Oliveira et al., 2017). Although there are available techniques to increase livestock production in a sustainable way (Ruviaro et al., 2016), adoption of modern technology is incipient and economic results often unsatisfactory (Dill et al., 2015). In addition, the inadequate use of grasslands has caused biodiversity reduction, landscape fragmentation,

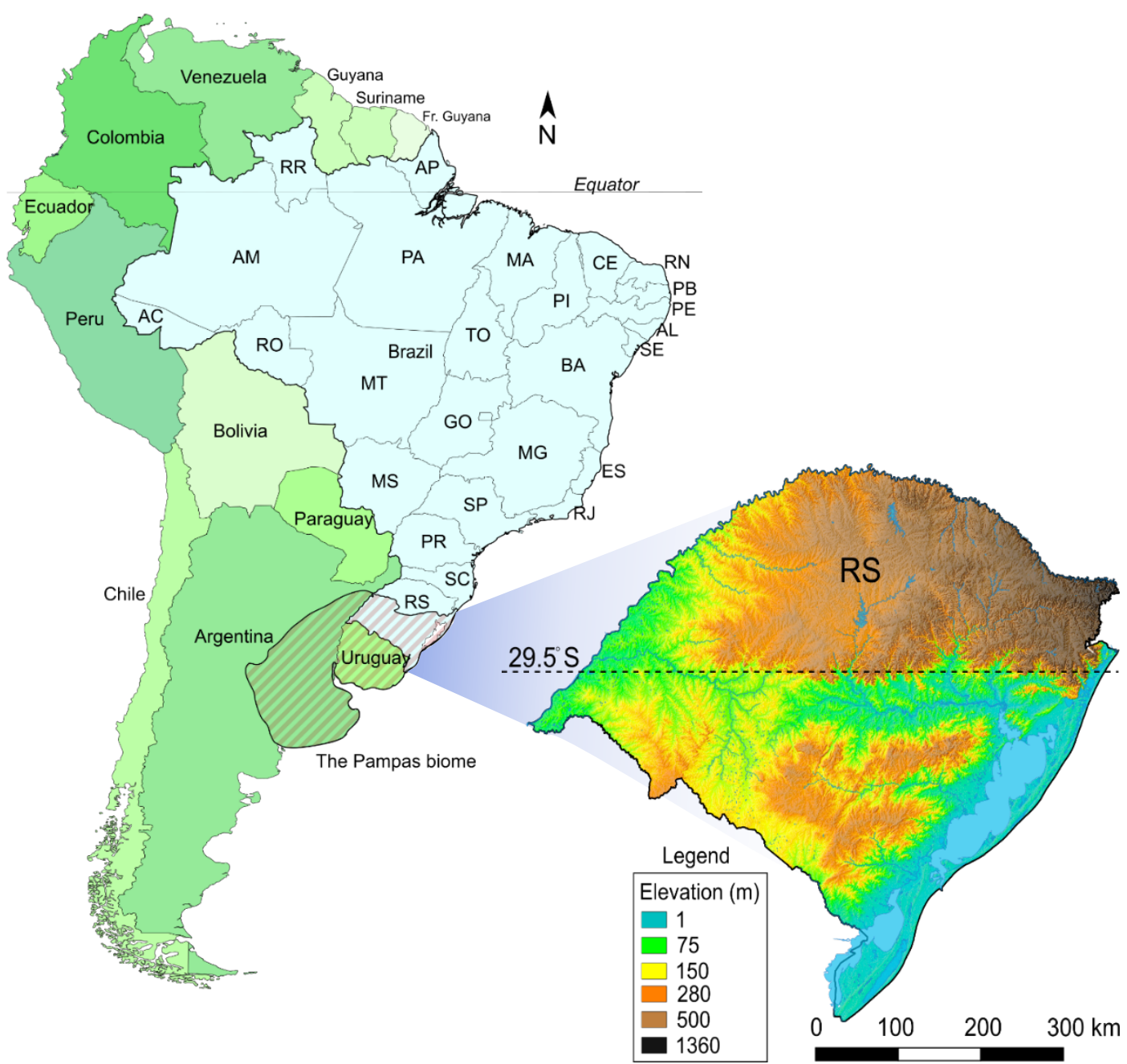

Figure 1. South America map, presenting the Pampa's biome and Brazil detailed by states. In the right side, map of Rio Grande do Sul (RS) state. The dash line identifies latitude 29.5S, which delimits the two main areas (north half and south half of RS). 
invasion of exotic species and soil degradation (Carvalho \& Batello, 2009; Nardin \& Robaina, 2010). This scenario, along with the increasing prices of grain commodities in international markets, has contributed to a gradual conversion of the flat grasslands into areas with other agricultural activities, that are often more attractive from an economical point of view.

\section{General characteristics of Rio Grande do Sul state}

The Brazilian state of Rio Grande do Sul is formed by two biomes: the Pampas in the south, and the Atlantic Forest, predominantly in the northern part. The Atlantic Forest biome, which corresponds to $13 \%$ of all Brazilian territory, extends from the south to the northeast of the country and is located mostly in the coastal region. Originally, the biodiversity in the Atlantic Forest was similar to what is found in the Amazon jungle, but the coastal forests were logged and transformed by colonizers in the past. In the RS, the Atlantic Forest biome currently retains only $8 \%$ of its original extent (SOSMA, 2015), a level of preservation that is even lower than that found in the Pampas biome. The large reclamation of the Atlantic forest occurred by colonizers during the migratory wave initiated in 1824 , when the forest was exploited for wood and gradually transformed in agricultural fields.

The conversion of original landscapes to crop fields in both forest and grassland biomes was the main reason for the large increment in the area cultivated with grain crops in RS. Consequently, the RS was, for a long time, considered an agricultural state (Batista \& Silveira, 2006) and locally known as "the Brazilian barn" (the bread basket), since the state was the largest producer of several agricultural products such as wheat, maize, hay, barley and soybean, cultivated in the northern part, and rice, cultivated in the lowlands of the southern part. The RS was the first state in Brazil to cultivate soybean on a commercial scale, of which the expansion started in 1950, in the forest-reclaimed fields in the northern part of the state. From there, soybean expanded to the other states of south Brazil in the early 1970's, and, ten years after, the crop gained large terrain in the central and northern states of Brazil. In a meanwhile, the expansion of cropping systems focused on rainfed crops in southern RS was somewhat limited, until the boom of commodities started in the first years of the new millennium.

In 2015 the ten most important grain crops in Brazil covered a total of 57 million hectares. The RS accounted for $15 \%$ of this area, with a cultivated area close to 8.4 million ha, from which $87 \%$ were crops seeded in the spring-summer season (soybean, maize, rice, beans, sunflower and sorghum) and 13\% corresponding to winter cereals (wheat, oats, barley and triticale) (IBGE, 2016). Currently, the RS is still the largest producer of rice and wheat in Brazil, 
but, despite still being an important player, it has lost its former status of largest Brazilian 'farm'.

RS is located within the southern temperate zone and the climate is predominantly humid subtropical (Cfa, according to the Köppen's classification (Alvares et al., 2013)). There are four well-defined seasons, the average temperature is $17.8^{\circ} \mathrm{C}$ and the rainfall is relatively well distributed throughout the year, with accumulated precipitation near to $1370 \mathrm{~mm} \mathrm{yr}^{-1}$. Mean precipitation in the warmer months (October to March), which coincide with the cultivation of most extensive crops (soybean, rice and maize), ranges from 700 to $990 \mathrm{~mm}$, with an increasing gradient from south to north (Figure 2-A), of which a little $460-580 \mathrm{~mm}$ is accumulated in the soil (Figure 2-B).

The south of Brazil has strong and consistent precipitation anomalies associated with the climatic phenomenon El Niño Southern Oscillation (ENOS). There is an excess of rainfall in El Niño years and a trend for droughts in La Niña years, and this influence occurs mostly during spring and early summer (Cunha, 2001). Overall lack of rainfall is the most common climatic factor associated with yield losses in rainfed crops and pastures. Soil water balance in most regions is normally not sufficient to satisfy the needs of water by rainfed crops, which limits the expression of high yields, especially in La Niña years (Franke \& Dorfman, 2000; Puchalsky, 2000). The strong effect of a reduced agricultural production caused by La Niña events in the RS economics, as occurred in 2005 and 2012, is illustrated in Figure 3. In approximately four out of ten years there are agricultural losses caused by limited rainfall
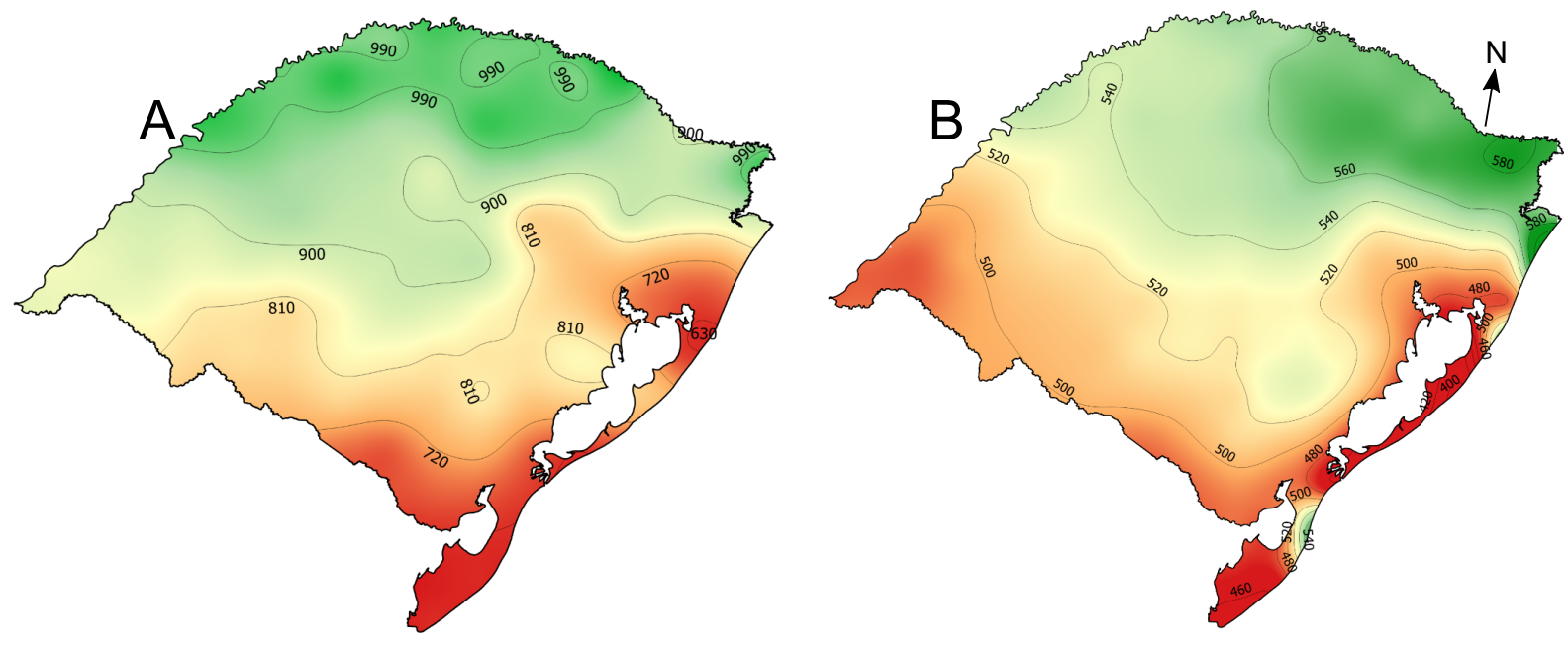

Figure 2. Precipitation (A) and moisture accumulated in soil (B) $(\mathrm{mm})$ in warmer months (October to March) in Rio Grande do Sul, Brazil. Averaged from 1981 to 2010. Source of data: NCEP, 2014. 
(Britto et al., 2006). All rice in lowlands is irrigated by surface irrigation and is not affected by droughts. However, the area irrigated with other crops is limited. Estimates of the area of upland crops irrigated with central pivots range from 0.11 million ha (Martins et al., 2016) to 0.20 million ha (Telles, pers. comm.) ${ }^{6}$, whereas around 10,000 ha of pastures are irrigated by some kind of irrigation system (Emater RS, 2015). In any case, the proportion of upland crops depending exclusively on rainfed water is high (around 90\%, excluding rice). Increasing the water use-efficiency of non-irrigated crops is therefore a challenge for most cropping systems in RS.

\section{Economy and Agriculture in the RS}

The RS is the $4^{\text {th }}$ richest among the 27 Brazilian states, with agriculture providing around $33 \%$ of the overall gross domestic product (GDP) in the state (Borges, 2016). There are substantial differences in the economy and development between the northern and southern parts of the RS (map in Figure 1) (Coronel et al., 2007; Borges, 2016). The northern part has been responsible for almost $70 \%$ of the GDP, and presents better quality of life and welfare than in the south. Both the United Nations Human Development Index (HDI) and the locally-tailored IDESE index (Kang et al., 2014) are, on average, significantly higher for municipalities located in the north than for those in the south of RS. Substantial part of these differences is connected to agriculture: the north has a diversified agriculture and subsidiary industries which generate a continuous flow of jobs and wealth, while in the south, agriculture development and crop diversification have been limited. Factors associated to weather and soils, as well as the historical prevalence of rice as a monocrop and the low efficiency of livestock production are contributing to this (Sório Jr., 2001; Rocha, 2011).

Differences between the south and north parts of RS state are also associated with the landscape and culture. For instance, the topographies are quite different, with high altitude and undulated terrains in the north and flatter lower altitude areas in the south. Some socio-cultural aspects still remain from the ancient times in the countryside, like the larger farm sizes in the south (100 ha vs 37 ha, according to official statistics) as well as the lower population densities in rural areas in the south (8.8 vs 17.2 persons $\left.\mathrm{km}^{2}\right)$.

Despite the larger size and the agriculture-based economy for many municipalities in

6 Telles, João Augusto. President of the Irrigation Club in the RS state. Personal communication, January 2017. www.clubedairrigacao.com.br 
the southern half of RS, several studies describe a chronic regional economic stagnation (Batista \& Silveira, 2006; Fochezatto \& Ghinis, 2012). It has been argued that the differences between both regions could be alleviated if some changes in the agricultural matrix in the Southern Half, particularly an increased crop diversification and a more adequate use of resources, are put into effect (Paiva, 2008). Such changes could be the initial impulse to raise and stabilize earnings in the farming sector and the related chains of the associated agribusiness (trade, industry and services), which are major generators of jobs, income and development (Silva Neto \& Frantz, 2003; Feix \& Leusin Jr., 2015).

Figure 3 details the aggregated gross value from agribusiness in the RS from 1999 to 2014 , in the northern and southern regions of the state. What is easily distinguishable, is that the northern region accounts for the larger part of all wealth generated from agriculture, while the southern region represents a lower generation of resources as a whole, as well as a lower growth rate. In absolute numbers, the difference in growth rate equals to an average 226 million dollars a year, or to an approximate $\mathrm{R} \$ 432.5$ million $\mathrm{yr}^{-1}$, in the local currency (the Brazilian Real (R\$)).

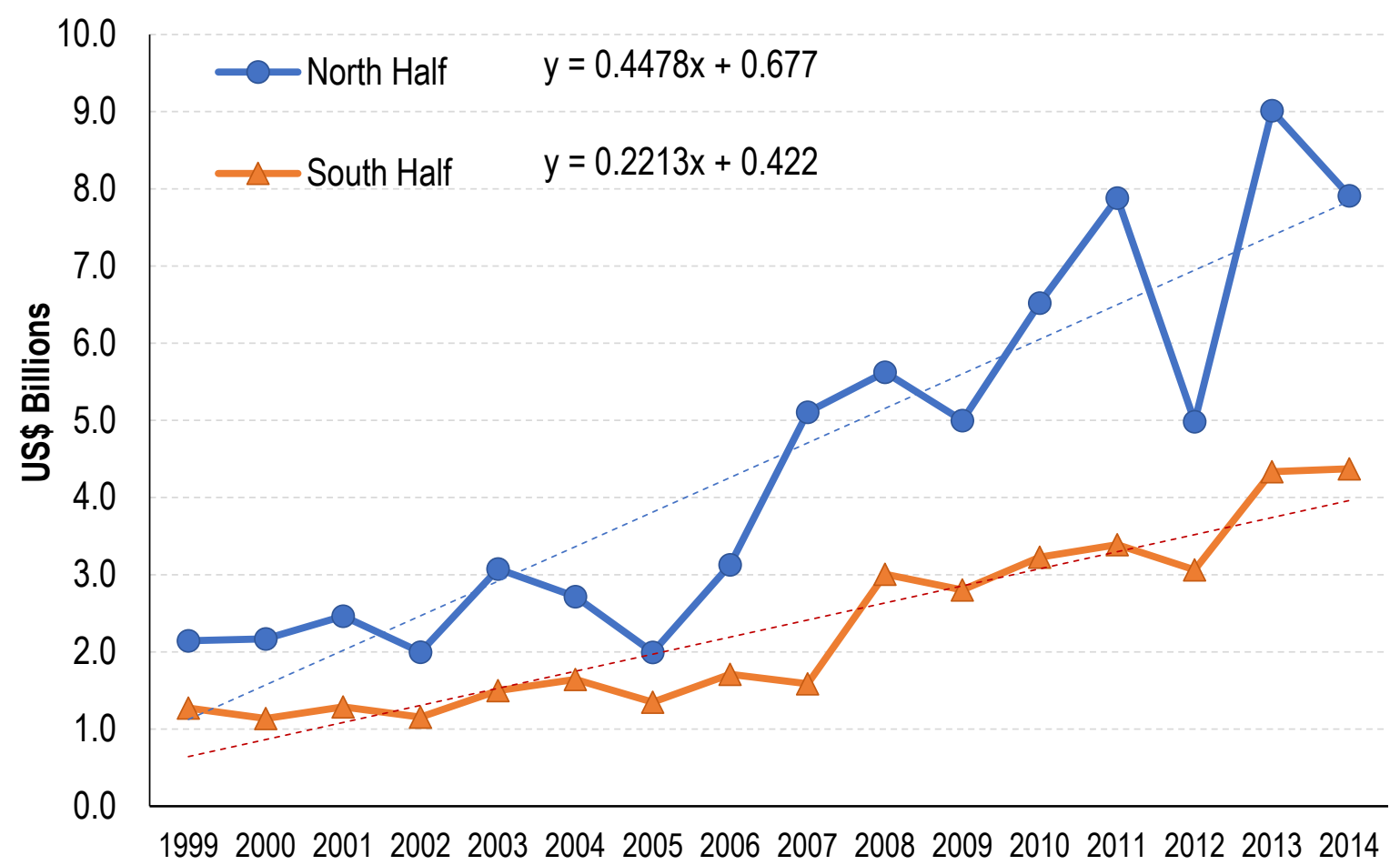

Figure 3. Aggregated Gross Value from Agriculture in the North and South regions of Rio Grande do Sul, Brazil. Source: FEE (Foundation of Economy and Statistics of RS), 2017. 
The agricultural economy in the south RS slightly changed following improvements in rice production, which were initiated with large extension projects released in 2002 (Gomes et al., 2004; Menezes et al., 2012), and as a consequence of a new cycle of expansion of soybean, starting more or less at the same time. From 2001 to 2015 soybean expanded from 2.7 to 3.7 million hectares in the northern RS, an increase of $37 \%$. In the south, the expansion was, proportionally, even larger, leaping from 0.35 to 1.5 million hectares (Figure 4-A), which represents an impressive 5-fold increase in area. Particularly in the south, this expansion of soybean did not came without a surge of criticism about the transformation of natural landscapes into soybean monocrop fields (Filipe et al., 2013; Ofstehage, 2016; Oliveira et al., 2017).

Although studies on regional development frequently claim that agriculture diversification is a way to improve regional progress (Benetti, 2007; Feix \& Leusin Jr., 2015; Pinto \& Coronel, 2016), a decrease in the acreage of many crops was observed in the southern region of RS during the last fifteen years. There was a reduction in area and production of maize (Figure 4-A), beans, barley and sorghum, whereas area and production of other grain crops, like oats (Figure 4-B), rye, triticale, sunflower and rapeseed remained relatively low (IBGE, 2017). The area cultivated with grain crops other than soybean and rice dropped from 450,000 ha in 2001 to 297,000 ha in 2015; a reduction of $34 \%$.

In terms of animal products, which industries -we emphasize- are known to create a considerable amount of jobs and regional wealth (Benetti, 2007; Borges, 2016), there was a reduction in almost all main categories in the south of RS. Between 2001 and 2013, pig production was diminished at a rate of 11,400 heads per year, poultry for meat reduced with 64,200 heads per year and egg production shrunk with over 360 thousand per year. It is worth to mention that, in the same time, in response to a growing demand, the production of these categories increased in the north of RS (Figure 5). 

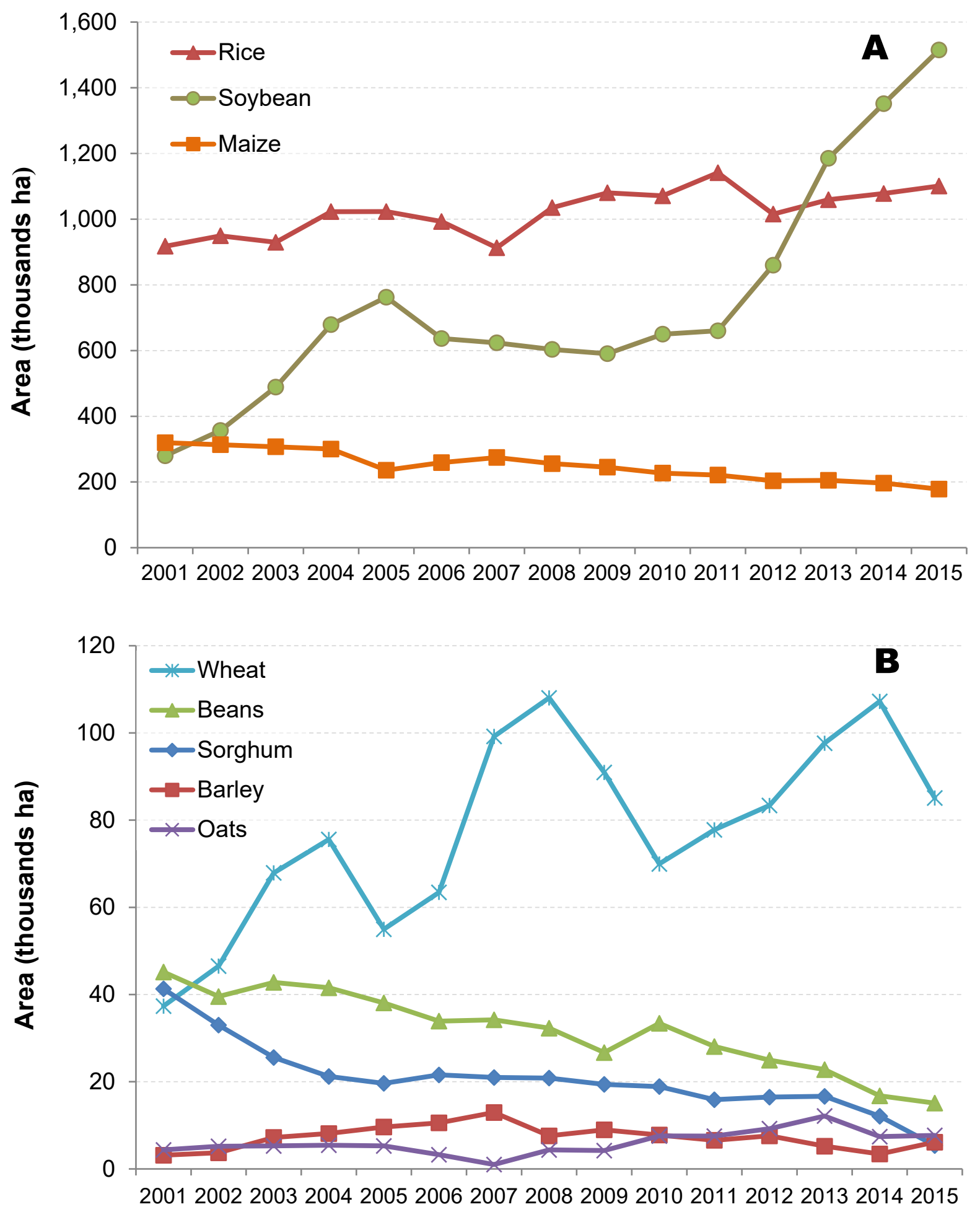

Figure 4. Area cultivated by major crops (A) and minor crops (B) in the South Half of RS from 2001 to 2015. Source: IBGE, 2017. 

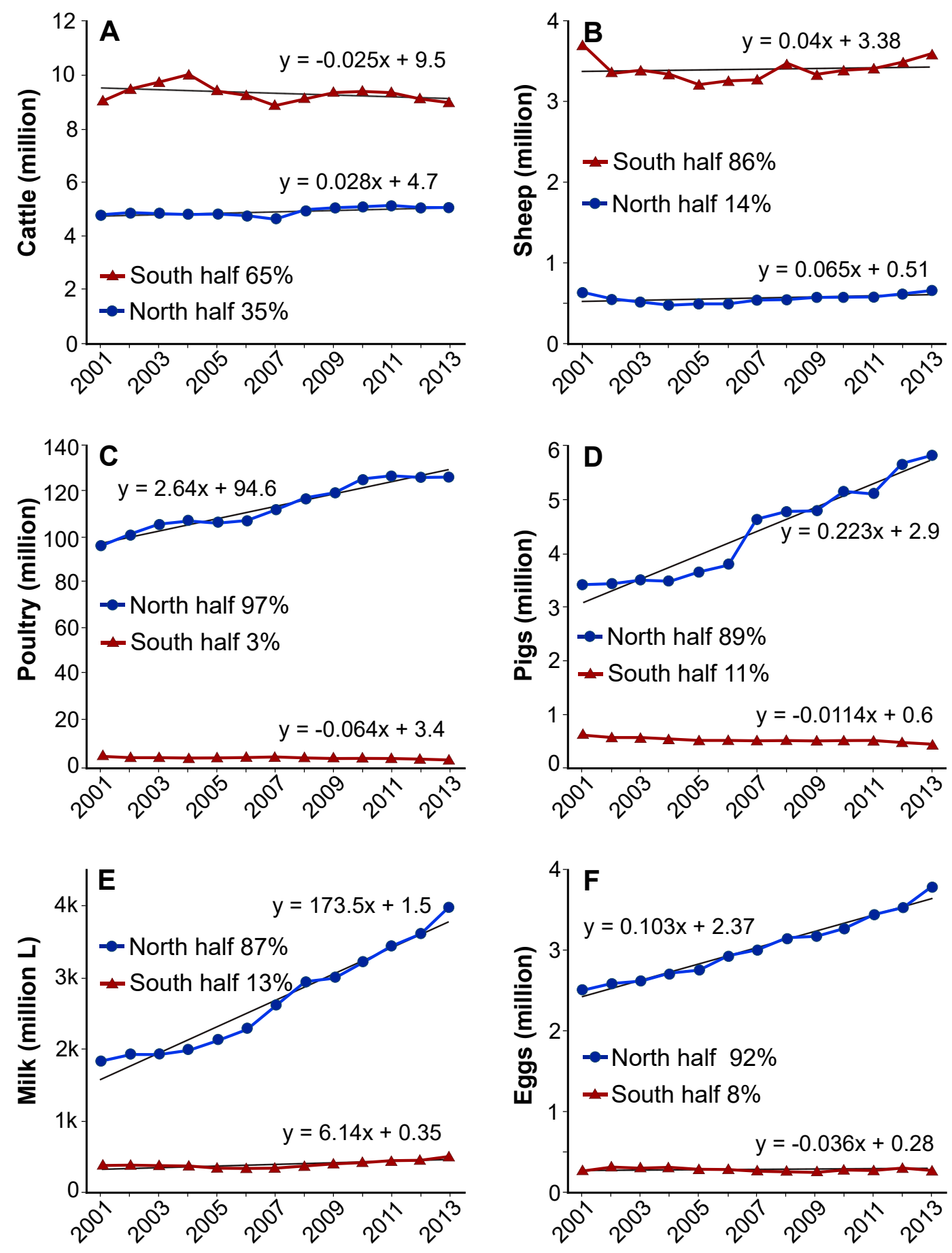

Figure 5. Herds and main animal categories produced in the RS, Brazil, in the northern and southern regions of state between 2001 and 2013. $\mathrm{A}=$ cattle for meat; $\mathrm{B}=$ sheep; $\mathrm{C}=$ poultry for meat; $\mathrm{D}=$ swine; $\mathrm{E}=$ milk; F = eggs. Data: IBGE, 2015. 
Despite the large area of native pastures in the southern part, also a long-term reduction in cattle (25 thousand heads less per year) and a strong difference in evolution of milk production (grew 28 times slower than in the north) was registered. Sheep was the only animal category which maintained a similar rate of increase between the two regions of RS (IBGE, 2016). One important reason for the mentioned overall reduction in animal production is the lack of maize-based feedstock at regional level, an issue still not satisfactorily solved until today. In fact, this is the most important problem faced by animal production, especially for eggs, poultry, pork, but also milk, as exemplified below:

\section{Box 1. Lack of maize at regional level and some consequences}

Chickens die due to lack of feed in RS

Source: Avicultura Industrial (Industrial Poultry magazine), 26 Sept 2002

Lack of corn raises hog price in $R S$

Source: Suinocultura Industrial (Industrial Swine magazine), 17 Dec 2007

Egg production will be affected by lack of maize in Brazil

Source: Gazeta Mercantil (newspaper), 28 Nov 2007

Lack of corn and soybean for animal feed reaches critical level in $R S$

Source: Federal Deputy Jeronimo Gorgen, 31 July 2012

Planting the lesser corn area in 45 years, Rio Grande do Sul increases dependence on soy and put soil at risk

Source: Notícias Agrícolas (Agricultural News website), 15 Sep 2015

Industry dispute maize for chicken

Source: Gazeta do Povo (newspaper), 14 Dec 2015

High corn prices can affect poultry and pork sector

Source: National Society of Agriculture (website), 21 Jan 2016

RS farmers want corn financing to enlarge stocks

Source: Canal Rural (TV channel), 01 Feb 2017

Obs.: internet links in Supplementary Information section, item A.

Since the first wave of soybean expansion in the south of the RS, between 2001 and 2005 , the primary sector became really euphoric with the new crop. With rising prices of soy on the international market, with a relative easiness to cultivate and with an abundance of inexpensive grasslands, which land prices were four times cheaper than in the north of the state 
(Schneid, 2009), soybean attracted great attention of farmers, grain merchandizers and supply companies. Simultaneously, the agricultural sector in south RS signalled, technically and economically, a need for more options than rice and livestock, hence stimulating the rapid increase in area cultivated with soybean. The crop rapidly raised from 300,000 ha in 2001 to almost 800,000 ha in 2005. Currently, in 2017, the one and half million hectares of soybean are located mostly in fields converted from native grasslands $(\sim 70 \%)$, in lowlands (approximately $23 \%$ ) and in areas converted to grain production in the past (around 7\%), where soybean substitutes maize, beans and sorghum (Silveira et al., 2017).

The dominance of monocrop soybean and the problems caused by lack of feedstock for animal production, motivated us (a group of researchers of Embrapa - the Brazilian Corporation for Agricultural Research) to enlarge the efforts to promote a more sustainable diversification of agriculture in the southern region of RS. As part of these efforts, a study on cropping systems, representing a wide range of options for agricultural production in lowlands, was installed early 2006. These systems were managed like real farms and scientifically assessed during nine cropping seasons. The plots were also permanently open to visits and judgements by farmers and agronomists.

The particularities of the lowlands will be discussed in the next section of this chapter. It is valid to mention that the lowlands are part of the Pampas biome and one of the most important eco-regions in south RS, house of 1.1 million hectares of rice and an extra area of almost 2.0 million hectares, already anthropized, but maintained mostly under fallow. Making better use of the lowlands can potentially diversify the agricultural production at regional level, alleviate the pressure of agriculture on natural landscapes and make current rice production more efficient.

\subsection{Cropping systems in the south-Brazilian lowlands}

\section{General aspects}

In the upland fields of the extreme south of Brazil, extensive livestock production (cattle and sheep) is a traditional and important activity that occupies the largest part of the land. With the recent soybean boom, predominantly the best pasture fields have been converted to grain-based agriculture, dislocating part of the herds to less productive grasslands (Oliveira et al., 2017). Additionally, as in other parts of Brazil, soybean has been preferred over other crops, especially maize. These are two important drivers, that have turned large parts of ecologically-rich 
rangelands, as well as other agricultural areas, into an almost-monocrop dominated landscapes.

A rational alternative that may help minimize the large-scale conversion of upland fields into grain-based monocultures is to focus on a better utilization of lowlands, where a large fraction of the available land has already been converted to agriculture and is used for cultivation of irrigated rice, soybean and livestock production, but many of these agricultural fields still remain in fallow. Lowlands are one of the most important components of the landscape in the south of RS, as well as in the nearby regions of Uruguay, Argentina and part of the coastal regions of Santa Catarina state, Brazil. In RS, lowlands occupy around 4.4 million ha (Figure 6). The larger part of these areas (around 3 million ha) already suffered anthropogenic alterations, mainly related to adjustments in the terrain to enable production of irrigated rice.

Table 1. Ecological regions of rice production in RS, flat fields up to $180 \mathrm{~m}$ altitude detailed by slope and area of irrigated rice in current cropping season $(2016 / 17)$.

\begin{tabular}{lccccc}
\hline $\begin{array}{l}\text { Ecological } \\
\text { region }\end{array}$ & $\begin{array}{c}\text { Flat fields } \\
\text { below } \begin{array}{c}\text { 180 } \\
\text { (ha) }\end{array}\end{array}$ & \multicolumn{2}{c}{ Terrain slope (\%) and area (ha) } & $\begin{array}{c}\text { Area cultivated } \\
\text { with rice (ha)* }\end{array}$ \\
\cline { 2 - 6 } & & 0 to 1\% & 1 to 2\% & 2 to 3\% & \\
\hline A. West Frontier & $1,225,080$ & 282,820 & 555,750 & 386,510 & 320,780 \\
B. Campaña & 808,850 & 198,510 & 371,040 & 239,300 & 168,570 \\
C. Central & 467,050 & 104,130 & 209,590 & 153,320 & 143,690 \\
D. Internal coast & 426,710 & 115,830 & 196,390 & 114,490 & 150,260 \\
E. External coast & 614,550 & 211,560 & 282,020 & 120,970 & 138,770 \\
F. South zone & 872,020 & 280,250 & 404,400 & 187,370 & 184,100 \\
\hline \multicolumn{1}{c}{ Totals } & $4,414,260$ & $1,193,100$ & $2,019,190$ & $1,201,960$ & $1,106,170$ \\
\hline
\end{tabular}

Calculated by the author using GIS software, based on the ALOS World 3D - 30m provided by Jaxa, Japan. * Irrigated rice in cropping season 2016/17 (Data: IRGA-RS, updated April 2017).

In these wetlands, there is a considerable area available for grain production, where crops could be cultivated in rotation with rice, or even constitute new cropping systems. There are some known restrictions related to soil management for rain-fed crops in lowlands, but the potential to diversify and increase production exists and should not be ignored. Currently, rice is the first and soybean is the second most cultivated crop in this environment. Soybean and other rainfed crops use, however, less than one fourth of the most easily drainable areas. Information about the terrain, ecological regions for rice production and current area cultivated with rice, as well as the localization of lowlands within the RS are shown in the Table 1 and 
Figure 6.

Although grain crops in the lowlands of RS are currently almost limited to rice and soybean, management of cropping systems composed of these crops can be complex and highly different. The management of these fields has to take into account factors like integration with livestock production, rice technology (e.g. herbicide tolerance), pest intensity and soil management. Crop-livestock integration (CLI) is one important component in this context, since the fields can be economically exploited for a larger part of the year. According to local experts, best results on CLI are expected from fields where there is a planned rotation of rice, soybean and cattle production conducted in pastures composed of grasses and legumes. Such ideal conditions, however, are hardly met in the very flat soils and also require expertise which is not always available to farmers.

Four arrangements of the most commonly used cropping systems in lowlands of the RS state are described in Figure 7. In systems A, B and C, grain production is exclusively based on

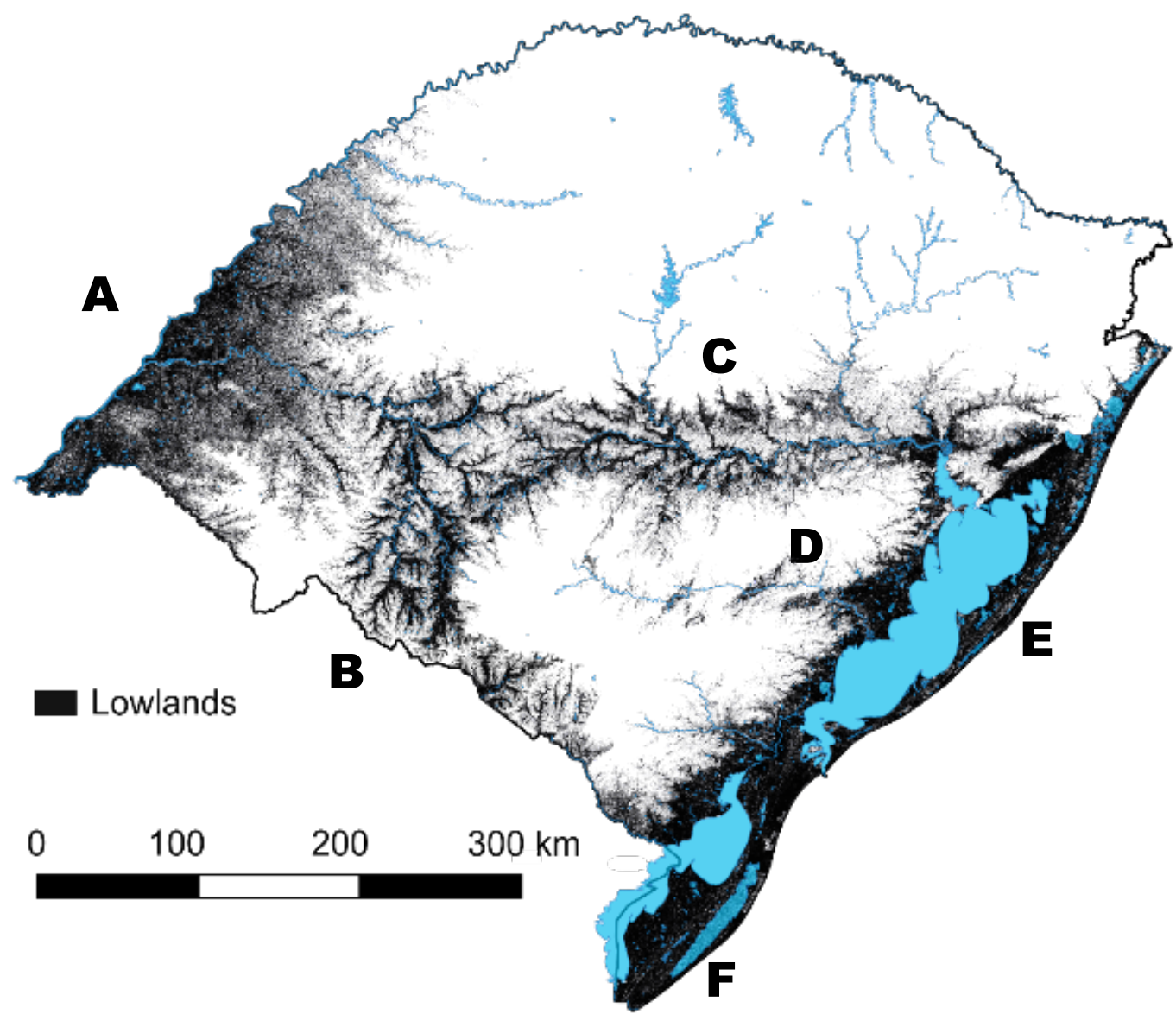

Figure 6. Map of RS state, Brazil, with flat soils up to $180 \mathrm{~m}$ altitude (dark dots) and larger water systems (blue). Letters represent the main ecological regions for rice production according to IRGA-RS (the RS Rice Institute). See Table 1 for names and details. 
rice, but at diminishing intervals between rice cultivation: from four-year (A) to two-year fallow (C). During fallow, the field is -or is not- used for livestock production, depending on the farm logistics and agreements between rancher (the owner of the land) and farmer (rice producer) in case of rented fields, on which approximately $60 \%$ of the rice is produced. During long intervals, like the one depicted in (A), the field will most likely be cultivated with pastures, while during short intervals between rice (e.g. in (C)), fallow with spontaneous natural vegetation is a common option.

The integration of irrigated rice and extensive cattle has historically been the main arrangement in the farming systems of the lowlands of RS. The main reasons which have contributed to this are:

a) the natural aptitude of rice for the wetland agro-environment;

b) the high importance of cattle for the regional economy;

c) the system of land use and possession, largely based on renting of fields;

d) an almost absence of risk of drought to irrigated rice, if compared to rainfed crops;

e) lack of technologies and cultivars to permit a successful introduction of rainfed crops in lowlands in the past;

f) ranchers, farmers and a commercial sector accustomed to deal with rice and livestock demands;

g) the good complementarity between rice production and cattle.

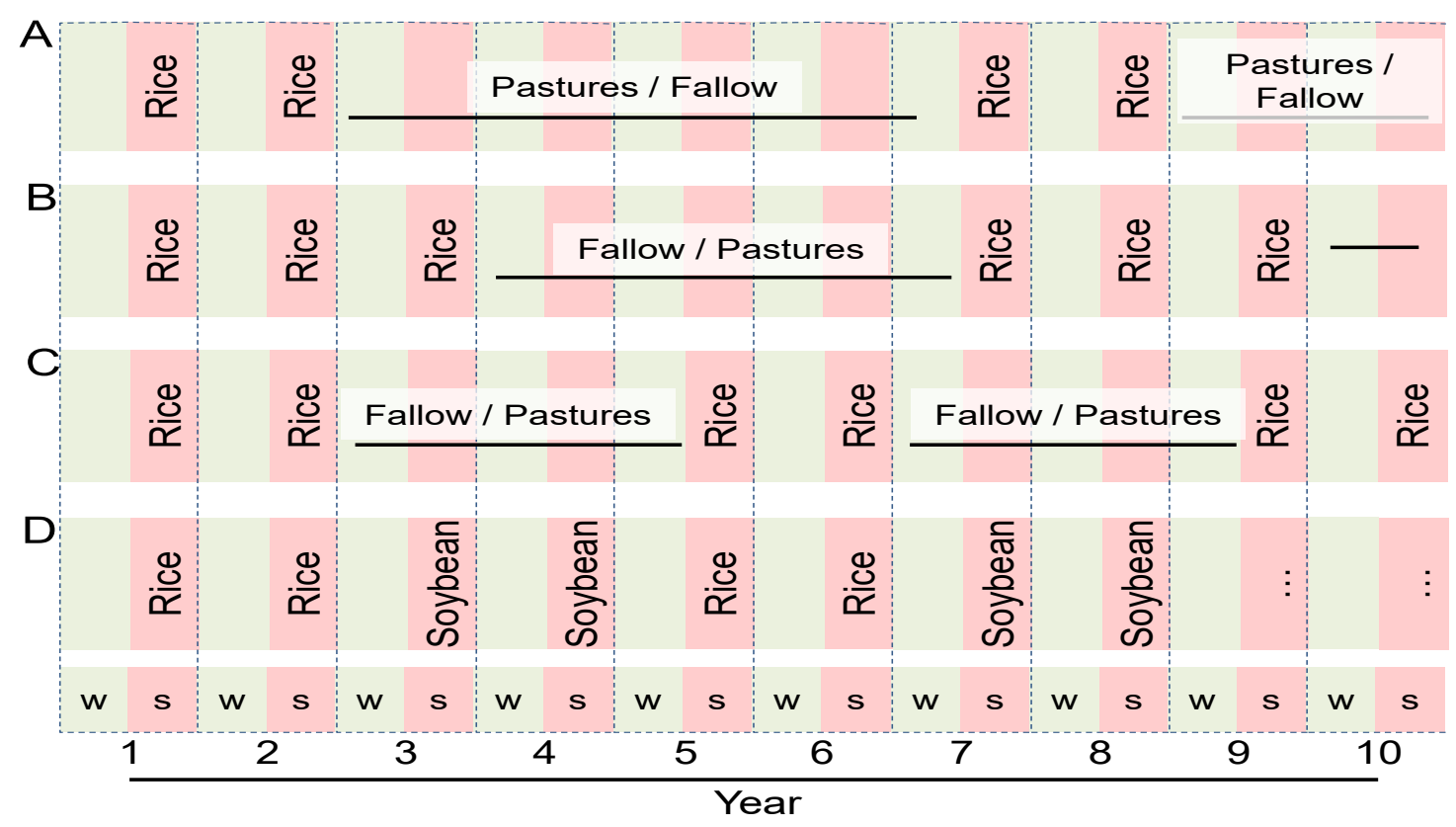

Figure 7. Cropping systems commonly used for grain production in lowlands of Rio Grande do Sul, Brazil. w=winter (April-September); s= summer (October-March). 
Rice-fallow still represents the predominant cropping system in the lowlands of south Brazil. However, the scenario of agriculture in the wetlands slightly changed with the attractiveness of soybean and the intensification of rice production. Rice yield in south Brazil is around $8 \mathrm{Mg} \mathrm{ha}^{-1}$ (2017), approximately $1 \mathrm{Mg}$ higher than the yield reported for traditional producer countries like China and Japan (CGIAR, 2017) ${ }^{7}$. The elevation of rice yields following from crop intensification- have promoted the occurrence of nutrient limitations and, in several cases, of herbicide resistant weeds. The rice-livestock integration, despite its positive influence, is not sufficient to completely overcome these limitations. To fill this gap, the inclusion of soybean was identified as one of the best options: soybean potentially improves soil fertility, contributes to weed management and is a grain crop with a high market value.

Rice-soybean (Figure 7-D) is the cropping system with the largest increase in the last fifteen years in the lowlands of RS. Currently (2017) this cropping system is used on around 250,000 ha (out of 345,000 ha with soybean in lowlands). Soybean has been tested by official research in lowlands since 1950's (Vernetti \& Vernetti Jr., 2013), but for a long time it was considered a high-risk, secondary crop in these environments. The situation changed, especially due the increased prices for soybean, the availability of glyphosate-tolerant cultivars, the migration of soy-experienced farmers and input suppliers from the north to the south of RS, and with the acquired expertise from the south farmers (especially the pioneer ones) for the new crop.

A common scheme for rotating rice and soybean consists of an alternating cycle of two consecutive growing seasons for each crop. This model has advantages if compared to a shorter cycle, in terms of $\mathrm{N}$-dynamics in the soil, weed management and monetary costs. As the natural occurrence of effective strains of N-fixing bacteria Bradyrhyzibium can be low in the wetlands (Scholles \& Vargas, 2004), the first cultivation of soybean can lack the nodulation, thereby limiting yield. Second-year soybean normally does not present this problem since the bacteria in the soil is augmented from the first cultivation. Also in terms of weed control, two consecutive seasons of soybean has been shown as a good form of weed management, since glyphosate and ACCAse-inhibiting herbicides, both used in soybean, provide a good control of grass weeds, which is the most problematic class of weeds in rice. Finally, a two-year ricesoybean rotation also represents fewer costs than the 1:1 scheme, since the operations required to make the field ready for rice irrigation are energy and monetarily expensive. Rice-soybean

\footnotetext{
${ }^{7}$ Ricepedia database, a project of CGIAR. http://ricepedia.org/rice-around-the-world/asia
} 
rotations (2yr:2yr), conducted in conventional tillage and in minimum tillage, consisted in two out of the five cropping systems evaluated in the long-term experiment described in this thesis.

The intensification of crop production in the lowlands brought a potential problem in this water-rich environment. In general, the amount of inputs used in the fields has increased considerably. Higher yields of rice have been gradually obtained, but much of this increase in yield has been obtained at the expense of a substantial elevation of the use of nutrients and pesticides. In the same way, the increase in soybean cultivation carried an extra degree of risk to the wetland environment, since the crop is normally treated with at least two applications of herbicides, fungicides and insecticides. In a period of around 15 years, the standard-package of pesticides used in lowlands, basically composed of one application of herbicides and seed treatment of rice, changed to a full set of herbicides, fungicides, insecticides and seed treatment applied in both- rice and soybean. The lowlands constitute an environment where water is one of most important components, and measures which reduce the risk of water contamination, whilst maintaining food production, are especially welcomed.

The six ecological regions of rice production in the RS (Table 1) present proper characteristics related to soil and climate, as well as different farm profiles. Rice paddies are located from sea-level up to $180 \mathrm{~m}$ altitude. Thirty percent of all area in south RS can be classified as flat soils, which, according to Brazilian standards, consist of areas with a slope less than 3\% (Santos et al., 2006). Extremely levelled soils (slope less than 1\%) constitute $27 \%$ of the entire area of the lowlands. The size of rice fields in the lowlands of south RS is on average 115 ha, with the larger fields located in the regions West Frontier and South zone (Table 2). In comparison, in the uplands in the north of RS, the mean full-size of a farm is just 37 ha (IBGE, 2017). The relatively large size of the fields implies that almost all operations, e.g. soil preparation, crop seeding and nutrition, pest management and harvest, are reliant on a high level of mechanization.

Although irrigated rice represents just $2 \%$ of the whole area cultivated with agricultural crops in Brazil, the rice from the southern lowlands has a strategic importance at national level. Approximately $80 \%$ of rice consumed in Brazil is produced in the paddies of RS (70\%) and Santa Catarina (SC; 10\%) states. Importantly, rice is the main staple and source of energy for $82 \%$ of the Brazilian population, with an average consumption of $45 \mathrm{~kg}^{\text {person }}{ }^{-1} \mathrm{yr}^{-1}$. In comparison, flour-based products are consumed at an average rate of $40 \mathrm{~kg}$ person ${ }^{-1} \mathrm{yr}^{-1}$ (IBGE, 2017). 
An important fact regarding the land use and crop diversification in the lowlands of south RS refers to the proportion of fields that are rented. In 2005, at the time of the last census, more than half of rice production occurred in rented areas (Table 2). This condition is one of the historical reasons why rice and livestock have been kept as the very dominant agricultural system in a major part of the lowlands in RS (Rocha, 2011; Cruz \& Guadagnin, 2012). The rancher, which normally is the owner of cattle and of the larger portions of land, rents their lowlands to a farmer, traditional producer of rice, for two, three or even more cropping seasons. Several types of agreements exist, on the use of fields by cattle in winter, on the cultivation of winter pastures, on the application of lime or other soil correctives, and even on the use of water for irrigation. For a long time, and in most situations, this renting system results in a win-win situation for both partners. Ranchers gain since pastures benefit from the residual soil fertility following rice cultivation, and farmers gain, because cattle consumes grass weeds that continue to grow outside of a rice season, thereby reducing the weed seedbank. This strategy is especially of interest to manage red rice (the weedy biotype of Oryza sativa L., also known as weedy rice), one of the most serious weeds in irrigated rice in south Brazil (Ziska et al., 2015).

Table 2. Main characteristics of farms in lowlands of RS, Brazil. Source of data: IRGA-RS*.

\begin{tabular}{lcccc}
\hline Ecological region & Number of farms & $\begin{array}{c}\text { Average size } \\
\text { of rice fields } \\
\text { (ha) }\end{array}$ & $\begin{array}{c}\text { Rented land } \\
(\%)\end{array}$ & $\begin{array}{c}\text { Crop rotation } \\
\text { (\% of area) }\end{array}$ \\
\hline A - West Frontier & 1084 & 250 & 63 & 52 \\
B - Campaña & 1127 & 154 & 64 & 28 \\
C - Central & 3375 & 47 & 54 & 21 \\
D - Internal coast & 1371 & 95 & 62 & 18 \\
E - External coast & 1474 & 88 & 55 & 8 \\
F - South zone & 601 & 285 & 61 & 27 \\
\hline Total \& averages & 9032 & 115 & 60 & 29 \\
\hline
\end{tabular}

* Surveyed in 2004/2005, covering all rice farms in the RS state (IRGA, 2006).

More recently, the harmony between ranchers and farmers has been tested though. One of the first facts to upset this traditional partnership was the introduction, in around 2003, of Clearfield technology (CL) in rice, which allowed for the use of herbicides with a strong residual effect in rice paddies. These herbicides can affect the performance of pastures that grow after rice (Pinto et al., 2009) or even of conventional rice cultivars seeded in the next summer season (Villa et al., 2006). A second disturbing factor was the rise in land rental prices, 
promoted by the high demand for areas to cultivate soybean.

Independent of the variety of arrangements on land possession and use, the characteristic of a high fraction of lowland fields being rented has remained till today. This situation affects, to some extent, the evolution of more advanced cropping systems in these areas. Long-term investments, e.g. on soil drainage and on soil fertility, and management techniques (use of cover crops, for instance) have to be agreed on between owner (rancher) and renter (farmer), which do not always have similar interests. Nevertheless, seen from an optimistic perspective, it is worth to mention that a well-adjusted integration between cattle and grain crops is known to result in positive outcomes for both crop and livestock that are sharing the same area in distinct periods of the year (Faccio Carvalho et al., 2010; Martin et al., 2016). Taking into account the need to meet the interests of both ranchers and farmers, crop-livestock integration was included in two out of the five production systems submitted to the long-term evaluation, which is the main object of the research described in this thesis.

Cropping systems in lowlands are frequently characterized by a narrow range of species suitable for cultivation. This difficulty is well characterized in the case of south Brazilian wetlands, where, in 2005 , around $70 \%$ of the cultivated area was without any form of crop rotation (Table 2). This number has decreased nowadays since the area of soybean largely increased in the lowlands, but in a limited extension, since soil-related restrictions still hampers rainfed crops, and not one single species of interest became tolerant to a high soil watersaturation in the recent times.

The inherent limitation in lowlands for successful crop diversification, however, does not appear to be exclusive for the Brazilian fields. In the Indo-Gangetic plains of India, rice and wheat are almost the unique crops cultivated since the Green Revolution, but the recent drop in productivity growth is a concern for both crops (Sekar \& Pal, 2012). Concerns regarding limited crop rotation in lowlands also were noted by Garrity et al. (1990), who worked with rice-maize rotations in Asia. In synthesis, the demand for cropping systems that enable successful crop diversification in lowlands echoes across the world. Since lowlands from different places around the world share several mutual characteristics, the discovery of a novel crop, cropping system or an innovative technique would represent an important breakthrough worldwide.

\section{Characteristics of rice-based cropping systems}

Irrigated rice has been the main crop in the RS lowlands since the beginning of 1900's (Hadler \& Otero, 2008; Rocha, 2011). A rice production area of around 1 million ha has been 
maintained since 2004 in the RS (Figure 4-A). Between 2000 and 2015 rice grain yield increased at a rate of $170 \mathrm{~kg} \mathrm{ha}^{-1} \mathrm{yr}^{-1}$, achieving an average productivity of $8.090 \mathrm{Mg} \mathrm{ha}^{-1}$ in cropping season 2016/17 (IRGA, 2017). Figure 8 presents the evolution of rice grain yield, which is only cultivated in the south RS, as well as the evolution of yields of soybean and maize, separated per region (north and south) in the RS state. Rice clearly is the most productive and stable crop. For soybean and maize, the northern region of RS nearly always presented a higher productivity than the south.

The paddies in south RS are generally flat (Table 1). Heterogeneity of their soils is high, with Planosols (56\%), Chernosols (16\%) and Neosols (12\%) dominating (Streck et al., 2008). In many wetlands there is a dense, clayed sub-superficial hardpan located around 0.3 to $0.6 \mathrm{~m}$ deep. This layer contributes to avoid water percolation and helps to maintain the water in the paddies when rice is cultivated. The existence of a sub-superficial hardpan is typical for planosols and convenient for cropping rice, but can represent a drawback to rainfed crops, which do not tolerate high levels of soil water saturation.

Except for some areas in the West Frontier and Campaña regions, natural fertility in the planosols of RS is low to moderate both in terms of organic matter content and availability of the essential nutrients (Comissão de Química e Fertilidade do Solo - RS/SC, 2004). Surface irrigation increases soil $\mathrm{pH}$ and this solubilizes nutrients, especially $\mathrm{P}, \mathrm{K}$ and $\mathrm{Ca}$, which helps the absorption by rice plants. Non-irrigated crops, however, do not take advantage of this effect, and commonly require a higher amount of external fertilizers than rice to produce appropriately in these soils.

One of the difficulties with soil management in rice-based systems is represented by the large number of soil preparatory operations. Soil adjustments, like levelling and preparation of bunds, are required previous to rice cultivation but, different from most other crops, soil preparation is also needed after rice harvest. Combines (harvesters) and the accompanying grain carts cause deep tracks in the terrain when harvest is performed in a flooded soil, especially in a soaked, muddy field. In this situation, the paddy normally requires a complete set of operations to get ready for the next season. One or two deep ploughings, one or two passes of a disk harrow, levelling, and the re-construction of levees are the common mechanical operations. These activities ideally have to be performed when the soil is dry, which rarely lasts more than a few days in the fall and early-winter (just after rice harvest). It is not uncommon that farmers postpone the required soil preparation after rice cultivation for several months. This condition is an important cause for the nearly complete absence of grain crop cultivation 
during winter in the lowland paddies of south Brazil.

Taking these soil-related difficulties into account, two technical measures were planned, tested and presented in this thesis: the first is a method of soil preparation for rice-based systems, which requires less energy and time, and can be performed independent of the weather conditions. The second measure consists of the construction of large ridges, on which water saturation is no longer a restriction for the cultivation of crops, pastures or cover crops. Each of these measures, as well as the results obtained after their implementation, is detailed in separate chapters of this thesis.

Water management is one of most important issues in irrigated rice, since it interferes with several aspects of production. Field management, weed control, costs, grain yield and grain quality are the most relevant. Water is usually placed in the fields when rice presents three to four expanded leaves (V3-V4 in Counce's growth scale (Counce et al., 2000)). Depending on climatic conditions, production system and amount of stored water, the layer of standing water is maintained up to harvest. Water consumption depends on weather conditions, field management and soil type, and values of around 7000 to $8000 \mathrm{~m}^{3}$ water ha ${ }^{-1}$ are common (Sartori et al., 2013). In general, water for rice irrigation in the RS is provided through reservoirs protected by small dams (47\%), rivers (33\%) and natural lagoons (20\%) (IRGA, 2006).

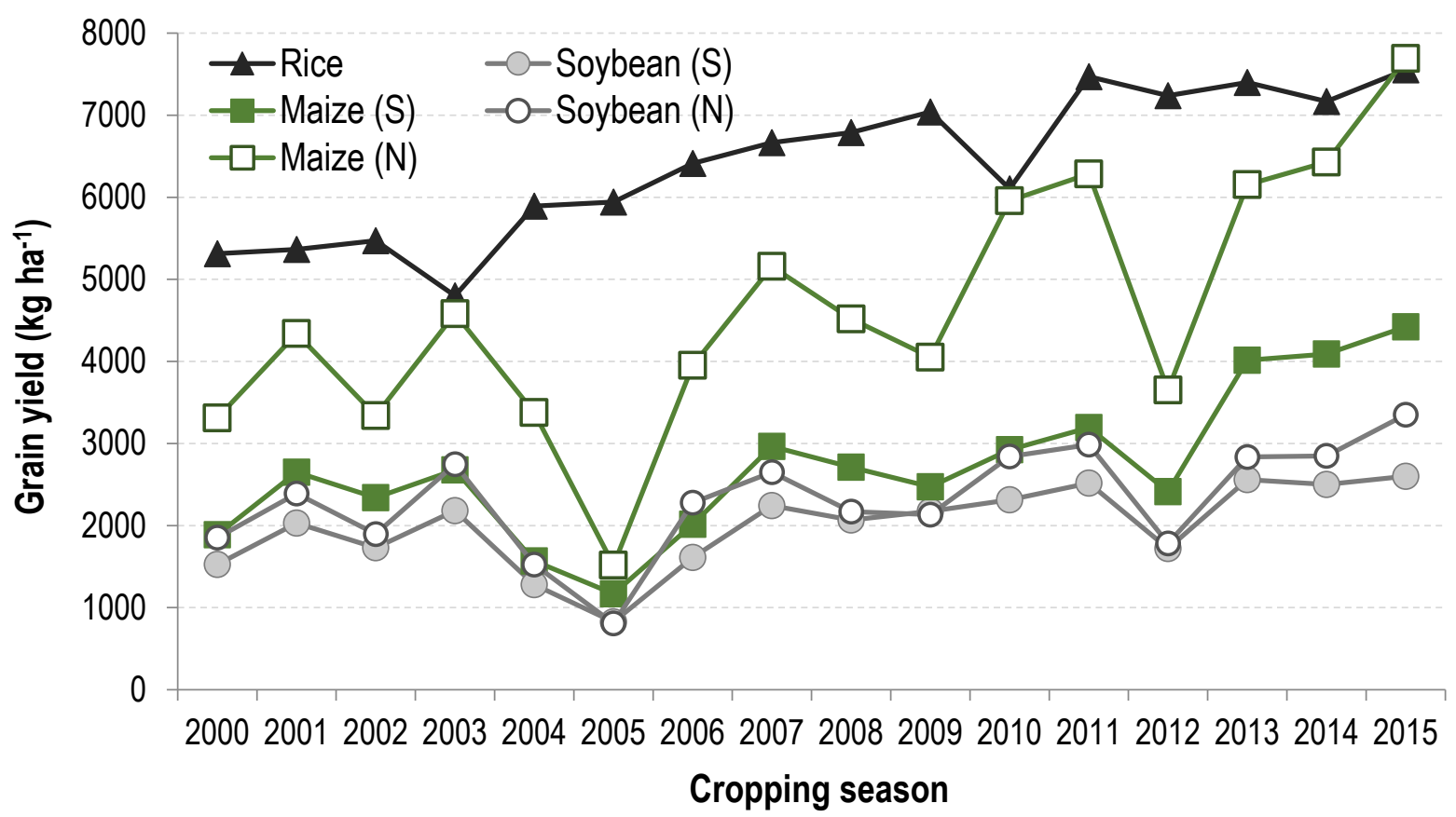

Figure 8. Grain yields of rice, soybean and maize from 2000 to 2015 in south (S) and north (N) regions of the RS state, Brazil. Rice in north is negligible and not included. Data: IBGE, 2017. 


\section{Minimum tillage, conventional tillage and pre-germinated systems for rice}

Between $70 \%-80 \%$ of rice production in RS is under minimum-tillage (IRGA, 2015). In minimum-till, rice seeds are direct-seeded in rows with a no-tillage seeder, approximately one week after herbicidal desiccation of the spontaneous vegetation or pastures remaining from winter. For this system, soil adjustments (e.g. soil preparation, levelling and construction of levees) are performed before the winter that proceeds rice cultivation (Figure 9-A). This early soil preparation permits to seed rice early on, which optimizes the capture of solar radiation during the crop cycle. In fact, early rice seeding has been an important factor associated with an increase in rice grain yield in the RS, starting at the beginning of this century (Mariot et al., 2009). Early soil preparation also enables an early start and thus an advanced growing of winter pastures, which contributes to improved cattle performance in fields practising crop-livestock integration.

To maintain a lowland field in minimum-till, the system depends on dry weather in autumn (March to May), since the soil preparation after rice harvest preferably needs a dry soil to be performed. As autumn is typically rainy, soil preparation usually cannot be performed on each field. Consequently, these paddies will remain fallow and only be prepared in next spring (September), using conventional plough-and-harrow practices (Figure 9-B). Hence, due to climatic restrictions, the conventional soil preparation system is still utilized in around $20 \%$ of the rice fields in RS. Postponing soil preparation to spring is not ideal, as for these paddies the time window to perform all activities and seeding rice is reduced. Over the years, the proportion of conventional tillage reduced from almost $70 \%$ in the early 2000's to the current levels, but a complete change towards minimum-tillage is still far from reality. In addition, conventional tillage is an option to tackle herbicide-resistant weeds and to temporarily reduce soil compaction, which is especially important for fields with rice-soybean rotation.

The pre-germinated system (Figure 9 C) was introduced in RS fields around middle 80 's, as a strategy to reduce losses caused by the weedy rice. The basis of this method consists of maintaining the soil flooded during the spring-time, the period in which the seedbank of weedy rice germinates. Paddies are filled with water as early as one month before the seeding of rice. As the seeds need oxygen to germinate and the layer of water depletes $\mathrm{O}_{2}$ from soil, the germination of weedy rice and several weeds is significantly reduced (Chhokar et al., 2014). Rice seeds are immersed for 1 to 2 days in water, and then spread in the soaked field after germination has started and seeds are in the early radicle expansion phase (SOSBAI, 2014). 

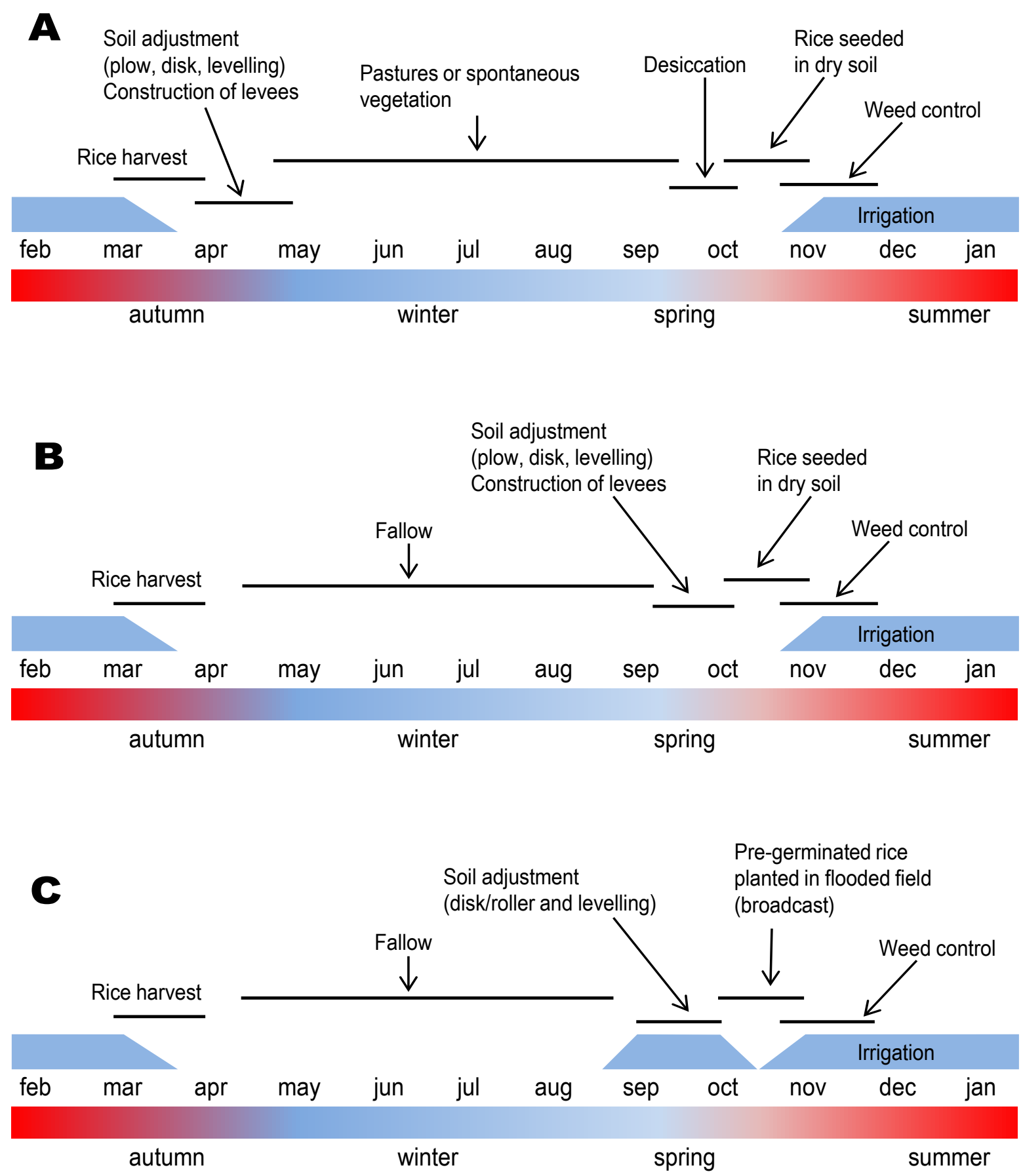

Figure 9. Simplified schemes of field, water and weed management for the three main production systems of irrigated rice in the south of Brazil. $A=$ minimum-tillage; $B=$ conventional system; $\mathrm{C}=$ pre-germinated system. The scheme illustrates part of a commonly used two-year rice rotation.

The pre-germinated rice system was used in up to $30 \%$ of all rice in RS around the beginning of 2000's. Currently the system is used in approximately $10 \%$ of rice fields in RS, predominantly in Central and Internal Coastal regions (Figure 6). In Santa Catarina state, the second largest supplier of rice in Brazil, practically $80 \%$ of all rice (nearly 120,000 ha) was 
cultivated using this method until recently (EPAGRI, 2015), but the system is being gradually substituted by minimum-tillage. In RS, the appearance of aquatic weeds and the new option for controlling weedy rice with herbicides (using the ClearField technology) reduced the importance of the pre-germinated system as a method for weed control in rice.

Lowland fields used for pre-germinated rice are levelled to a zero-slope, in order to maintain a uniform layer of water on the soil surface. While this strategy is suitable for rice cultivation, the flat levelling can present an inherent hindrance to the cultivation of rainfed crops. In these zero-slope fields, drainage is difficult and slow, since the gravimetric potential for runoff is almost nil. This condition, together with the presence of a hardpan layer in the subsurface, challenges the cultivation of rainfed crops or pastures in such an environment. The more than 190,000 ha converted to zero-slope fields in the lowlands of RS are in need of an alternative method for soil management, to improve diversification of grain production in these areas. In that sense, large-based ridges, short-based ridges, and the implementation of a net of small, high-precision subsurface drainage channels (Louzada et al., 2008) are some of the possibilities. Apart from the converted fields, there are about 1 million ha of naturally flat (slope $<1 \%$ ) terrains in the lowlands of RS-state.

\section{The ridge-based systems}

Ridge and furrow (RF) is a system for soil management used in many wetlands and arid regions around the world. It consists of the creation of sequential elevated strips in the terrain (the ridges) which can be built in diverse combinations of height and width. Annual grain crops can use a triangular-shaped ridge of 0.2 to 0.4 metres high with a width varying from $0.3 \mathrm{~m}$ to 1.5 $\mathrm{m}$. In wetlands, the system is used to protect crops from flooding and against the excess of water saturation in soil. In arid regions, the system serves to protect young crop plants against wind gusts and as a rainwater harvester, with the crops cultivated mostly near the humid furrows (Qi et al., 2015). The ridge-and-furrow system is also a method used to practise surface irrigation in several production systems in the world (Gan et al., 2013).

In south Brazil, the ridge-and-furrow system has been studied in lowlands by official institutions since the 70's, working mainly with maize, sorghum and soybean. Despite these experiences, the demand for crop diversification was not high enough to instigate machinery suppliers to develop -or import- ridge-seeders. The absence of this equipment limited to some extent the use of the RF system. With the recent interest of soybean cultivation in lowlands, one 
local industry ${ }^{8}$ developed a ridge-seeder for seeding two rows of soybean (50 cm apart) on the upper part of a formed ridge. Although the lack of seeders does not more represent a significant restriction to the use of the ridge-and-furrow, the system is still only used in a relatively small area. One reason for this is that the ridge system requires intensive soil preparation, and this makes the RF system operationally expensive and hardly compatible with conservationagriculture practises, like no-till and minimum-tillage. While the RF system potentially delivers one of the highest levels of productivity for soybean (Cassol et al., 2015) and maize (Porto et $a l ., 2004)$ in the wetlands, intensive soil preparation is questioned as a sustainable practise in the long run. Some field trials with RF conducted in minimum-tillage are on-going in RS (Donato \& Marchezan, apud Marchesan (2016)), but, although promising, more results are required to create a recommendation for farmers.

Ridge-and-furrow is effective to provisionally reduce the limitations for crop diversification in lowlands, like excess of water and high soil density. However, the intensive soil preparation makes the system hardly connected to long-term sustainability. Hence, considering soil drainage as a must-have to enable crop diversification in lowlands, and sustainable practises for soil management as the preferred way to improve the cropping systems in long term, we designed an alternative form of using ridges, on which we combined these requisites. In this new concept, instead of the temporary, narrow ridge model that just last for a few cropping seasons, a permanent, large ridge ( $8 \mathrm{~m}$ width) is used. Figures of a field with large ridges are presented in chapters 2 (page 52) and 3 (page 89).

Because of their inherent slope, the large ridges have enough gravitational potential to facilitate water run-off and improve soil drainage, which facilitates the application of management practices like the cultivation of cover crops, crop rotation and crop-livestock integration. The size of the ridges is large enough to remain intact in the field for more than one decade, and it enables that common agricultural practices (e.g. seeding and harvesting) can be performed without additional difficulties, using similar machinery as used in uplands. The large-based ridges can be constructed by directing the plough, harrow and levelling to form the desired shapes in the field, or adapting the equipment that are already used in soil levelling, like a planner (Figure 10). The ridges can present variable width and height, but it is perceived as a good practise to build them in a size that matches with a multiple of the distance of tractor wheels, or with once or twice the width of the cutter bar of a combine harvester.

\footnotetext{
${ }^{8} \mathrm{http}: / /$ www.industrialkf.com.br/produtos/ver/6/hyper+plus+camalhoneira. Accessed on 12 June 2017.
} 
The large ridges can be built after a cycle of two to three seasons of rice, and can remain for several years serving the cultivation of rainfed crops, cover crops or pastures. As an important advantage, the large-ridge system represents almost the only technique that permits the cultivation of high-quality cover crops as vetches (Vicia sp.) and oats (Avena strigosa), which do not tolerate excess of moisture in soil. By permitting no-tillage and the formation of a layer of crop residues on the soil surface, the large-based ridges represent a convenient method to simultaneously increase soil quality and improve diversity in grain production in the lowlands.

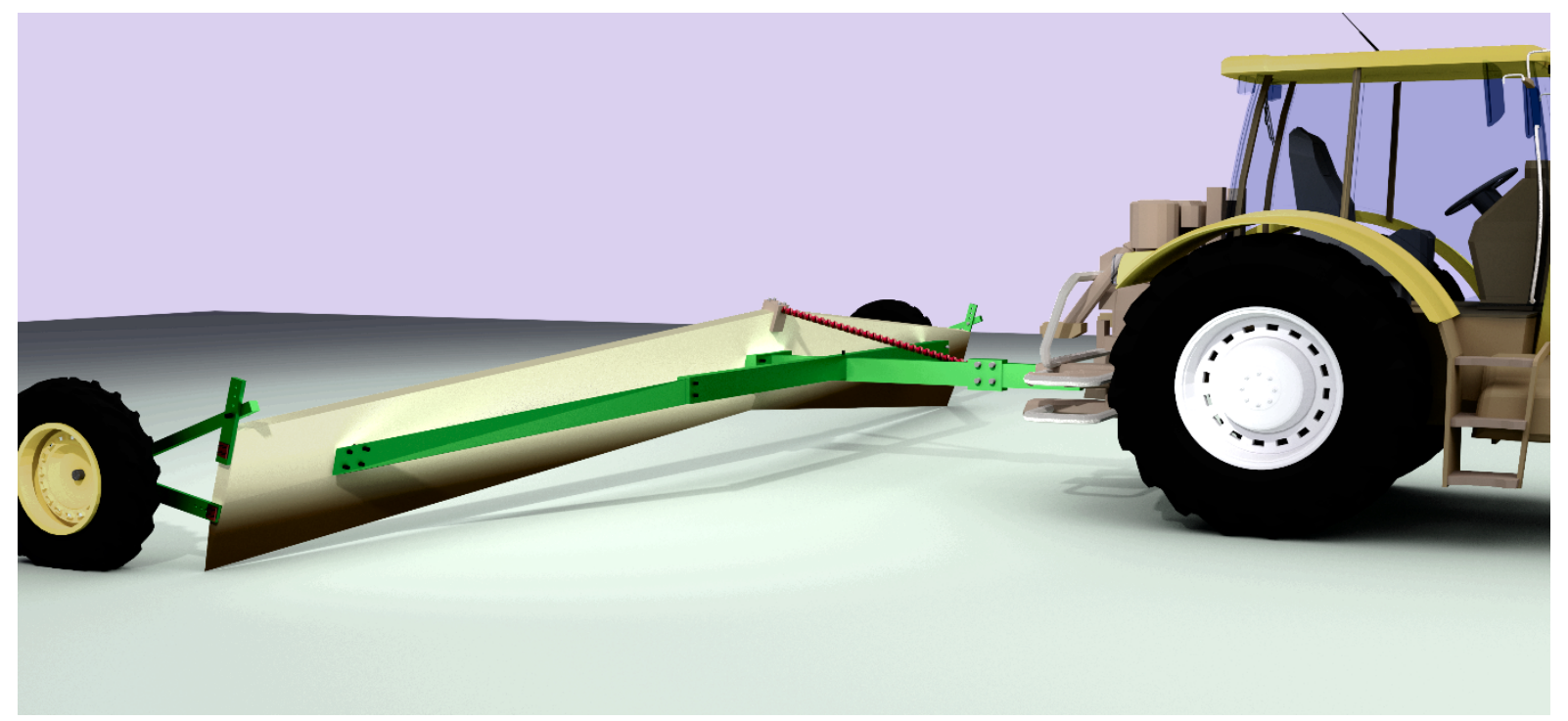

Figure 10. Equipment used for field levelling, like a blade-based planner, can be adjusted to build large-ridges in a paddy field.

No-tillage systems, however, have a drawback. These systems largely depend on herbicides for managing cover crops before crop seeding and for maintaining crops weed-free. Although mechanical techniques can be used to manage cover crops, almost all areas conducting conservation agriculture in south Brazil utilize herbicides. Lowlands are an environment in which water and aquatic-related lifeforms are abundant. Consequently, compared to upland fields which commonly are not surrounded by water, the use of pesticides in lowlands represents a higher environmental risk. Hence, to minimize the risk of environmental contamination by herbicides, non-chemical termination of cover crops and alternative techniques for weed management are required. In relation to this, we developed a tool, integrated in no-tillage seeders, which reduces soil disturbance at seeding and minimizes weed seed germination. A full description of this equipment, as well as the results obtained by using it in no-tillage fields, is described in the chapter five of this thesis. 
Two ridge-based systems were considered for our long-term study and are presented in this thesis. In the first system, a no-tillage rotation of soybean and maize were integrated with winter pastures and livestock production. In the second, no-tillage soybean and maize were integrated with winter cover crops, in a system in which soil quality was prioritized. Details and results for both cropping systems are described in the next chapters.

Pest management in the wetlands of RS.

In regard to the use of pesticides, wetlands are an inherently sensitive environment due to the presence of large amounts of fresh water and the diversity of organisms it harbours. In the south RS, one of the riskiest agricultural activities for the lowlands is represented by pesticide-use on cultivated crops. Pesticides are important to avoid crop losses, and generally offer a good economic return. However, these products embody a potential danger for contamination of water and agricultural products, thereby endangering non-target organisms and people. In south RS, approximately half of the pesticides in lowland crops are sprayed via aircrafts, and this kind of application is known for being more sensitive to wind drift than the soil-based applications. Aerial application is still not able to achieve high-precision deposition of products in irregularly shaped fields, and the field boundaries often consist of water channels, increasing the risk of water contamination. The threats represented by applying pesticides in the lowland environment are in practise almost unnoticed by farmers, as they tend to focus on more on the benefits (Finger \& Waquil, 2013).

The intensification of rice cultivation in the lowlands resulted in a clear increase in rice yields, but occurred to a large extent at the cost of an escalation in pesticide and nutrient use. A survey performed in the whole rice producing area in the RS in 2005 (IRGA, 2006), and a new survey conducted in 2012 in the western region of the state, clearly show the trends in the use of agrochemicals in rice production (Table 3). The strongest increases were in the use of insecticides and fungicides. While in 2005 insecticides were used in $61 \%$ of rice fields (at that time applied mostly by seed treatment), in 2012 they were applied in $74 \%$ of the paddies, which represents a net increase of 36.8 thousand hectares over the 280,000 ha of rice in the western area of RS. Most striking, fungicide use leaped from $5 \%$ to $71 \%$ of the rice fields; an increase in treated area of 179,000 ha in the western region. The higher use of $\mathrm{N}$ in rice, promoting nitrogen-induced susceptibility to diseases (Ballini et al., 2013) and the introduction of rice cultivars with low resistance to rice blast (Magnaporthe grisea) (SOSBAI, 2014), promoted this increase in fungicide use on rice paddies. Also the strong commercial appeal and positive 
responses in rice productivity following fungicide application played a role. Extrapolating these data to the full extent of rice cultivated in RS, suggests that 820,000 and 950,000 ha are now sprayed with insecticides and fungicides, respectively. Next to this, all of the 350,000 ha of soybean are also treated with these pesticides, and both, for rice and soybean, almost the full acreage is treated with herbicides.

Table 3. Synthesis of two surveys relating pesticide use on rice fields in RS.

\begin{tabular}{|c|c|c|}
\hline Survey $2004 / 05^{1}$ & $\begin{array}{c}\text { Area treated } \\
(\%)\end{array}$ & Comments \\
\hline Insecticides & 60.7 & - \\
\hline Fungicides & 4.9 & - \\
\hline Herbicides & 84.7 & - \\
\hline \multicolumn{3}{|l|}{ Survey $2012 / 13^{2}$} \\
\hline Insecticides & 74.3 & $15.5 \%$ are preventive applications \\
\hline Fungicides & 71.0 & $25.6 \%$ are preventive applications \\
\hline Herbicides & 86.3 & $49.7 \%$ of fields with weeds resistant to herbicides \\
\hline
\end{tabular}

The survey conducted in 2012 identified other worrying facts: $98.6 \%$ of the farmers affirmed that their rice fields had some kind of pest, but only $20 \%$ conducted field inspections to verify this pest occurrence. Approximately $26 \%$ of fungicides and $15 \%$ of insecticides in rice were reported to be applied preventively, without a valid technical criterion to support the application. These treatments represent, when projected on the overall RS lowlands, an area equivalent to 300,000 ha. These data are not so different of those presented by Theisen and Bianchi (2009), where a survey conducted in 24 cooperatives of soybean production in RS, representing an area of 2.6 million ha, identified that $26 \%$ of insecticides and $64 \%$ of fungicides were applied without a proper technical need, stimulated by commercial pressure but in the absence of an adequate decision support system. The overuse of pesticides is definitely not sustainable. In this thesis, the five lowland cropping systems were evaluated regarding pesticide use (Chapter 3). Several indicators associated to these compounds were established, and a technique to potentially reduce herbicide use in no-tillage fields will be presented (Chapter 5).

Weeds are the most important pest in the RS wetlands. Due to the large areas, the high weed density, the difficulty to implement crop rotation and the lack of labour to perform 
physical weed control, the prevailing method to reduce weed impact is through the use of herbicides. The most important weeds in dry-seeded rice in RS are weedy rice and barnyard grass (Echinochloa sp.). Both grasses are well adapted to submergence and are therefore common in wetlands throughout the world. Severe losses caused by weedy rice in the past forced farmers to abandon the most highly infested areas (Marchesan, 1994; Avila et al., 1999). Weedy rice was estimated to reduce rice production with as much as 35\% in the 1990 's (Avila et al., 1999). To face this threat, around $1 / 5$ of all cultivated lowlands were converted to zeroslope fields, to permit introduction of wet-seeding systems like the pre-germinated model. Next to the introduction of the pre-germinated system, rice-cattle integration was an important strategy to minimize the crop losses due to weedy rice.

Despite these efforts, no other method was as efficient in controlling weeds as the Clearfield $^{\circledR}$ technology (CL), which uses imidazolinone-resistant cultivars of rice. CL technology started to be used in the cropping season 2002/03 and rapidly spread among farms, such that $70 \%$ of all rice was tolerant to imidazolinone herbicides in less than 5 years. Currently (2017) CL cultivars are used in 90\% of the rice area in the RS, and in around $85 \%$ of all irrigated rice cultivated in south Brazil. Despite the success of CL on weed control, the evolution of ALS-resistant biotypes of weedy rice and other weeds did not take long to appear, following the strong selection pressure for this class of herbicides. Menezes et al. (2009) reported imidazolinone-resistant weedy rice to be present in all regions of rice production in RS. Later on, studies conducted by Roso et al. (2010) and Goulart et al. (2014) confirmed the fast dispersion of resistant weedy rice. These studies also indicated that the resistant biotypes of the weedy rice originated from natural crossing with Clearfield cultivars. The temporal evolution of ALS-resistant weedy rice in south RS is depicted in Figure 11. The data is summarized from monitoring services conducted by IRGA, the Institute Rio-Grandense of Rice (Menezes et al., 2009).

In spite of these problems with resistance, the use of ClearField cultivars is still the main tool to control weeds in irrigated rice in RS. Following the outbreak of resistance, farmers increased the use of additional weed management strategies, like rotating rice with soybean, conducting mechanical soil preparation before rice seeding, using herbicides from other classes, like the ACCASE-inhibitors, and using a larger proportion of high-quality rice seeds. From the cropping system's perspective, the occurrence of weed resistance in rice is a strong reason to practise crop rotation, adopt other techniques for weed management, like cover crops, or even to change the rice-based system to a production model which does not include irrigated rice. 


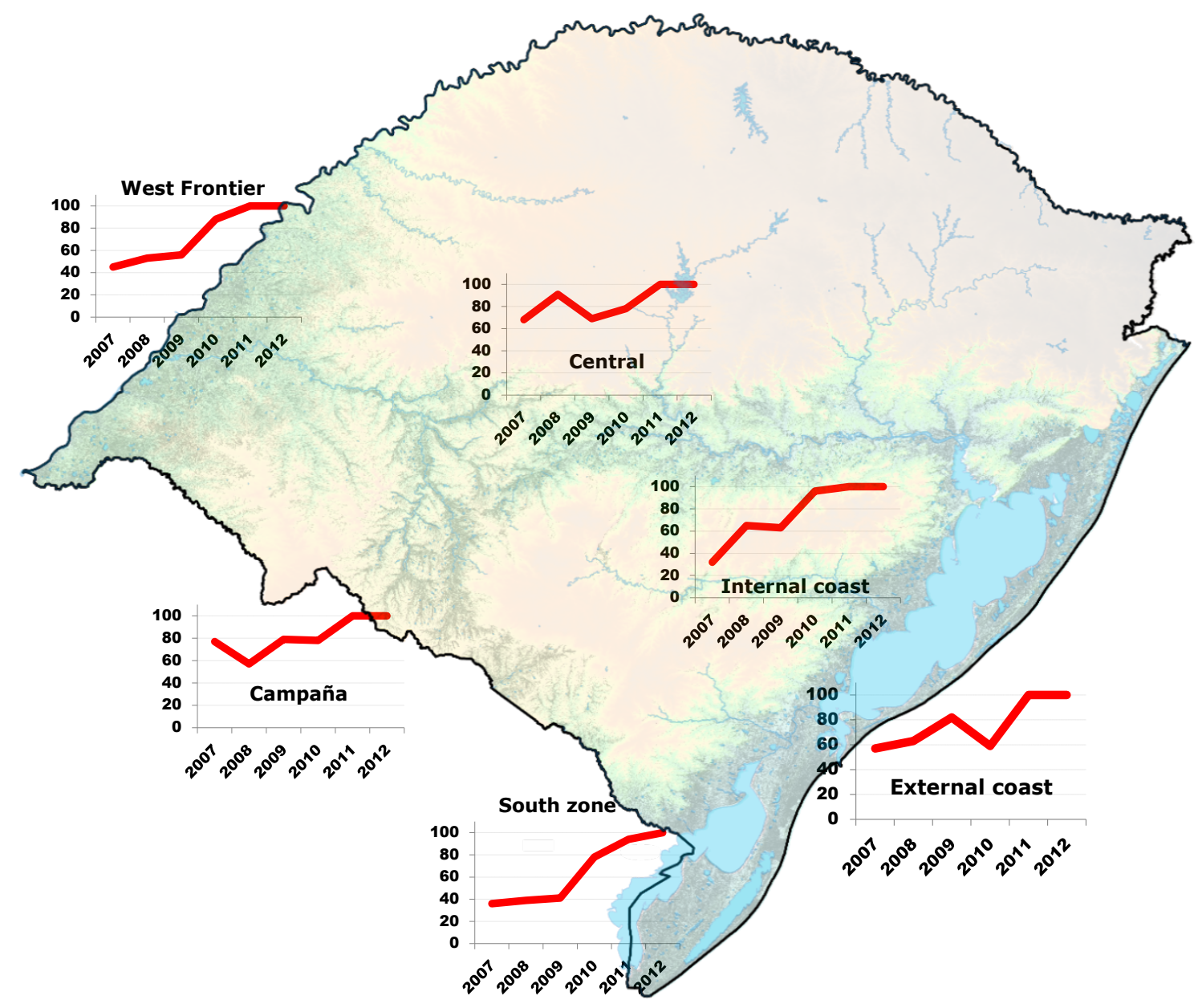

Figure 11. Evolution of imidazolinone-resistant weedy rice (Oryza sativa) in the ecological zones of rice production in RS from 2006 to 2012. Y axis indicates the percentage of resistant biotypes from fields where fails in chemical control occurred.

\subsection{A synthesis of main restrictions for a diversified and more sustainable agriculture in}

\section{the lowlands of RS}

By nature, wetlands are a challenging environment to practise diversified agriculture. Except for rice, whose morpho-physiological plasticity permits its cultivation in flooded or highly saturated soils, no other crop has the ability to produce such high yields in this environment without intensive interventions. There is not just a single obstacle to produce diversified crops, pastures and cover crops in the wetlands. Various restrictions are present, which interact, vary according to climatic conditions, are affected by the predominant tenure system and even depend on the skills of the farmer. No simple solutions to a multi-faced, complex problem exist. By knowing the obstacles for implementation of crop diversification, targeted solutions can be 
designed. In that sense, Figure 12 represents the main restrictions and the relations between the diverse components of agriculture in the lowlands. Not all fields present all these difficulties simultaneously and in a similar intensity, but the schematic drawing is an appropriate representation of what happens in most instances.

\section{Difficulties associated with soil structure}

The soils in lowlands are frequently exposed to dynamic changes associated to their hydraulic status. In the planosols, the excess of water causes chemical reduction, which affects nutrient availability and also results in the development of a typical grey colour. A prominent feature of these soils is the presence of an alluvial surface horizon, normally with sandy or medium textures, contrasting with the underlying B horizon, which is highly concentrated in clay. The top layer of most planosols used in rice production in RS can be unfavourable for the development of rainfed crops. These soils have commonly low porosity, predominance of micropores, compacted layers near the surface, low aggregate stability and a strong tendency of forming soil crusting when dry (Gomes et al., 2006). These characteristics cause these soils to have a low speed of water infiltration, easily accumulating water in the surface. The low concentration of oxygen in the root zone can limit adequate root functioning and prevent the development of several beneficial microorganisms, such as $\mathrm{N}$-fixing rhizobia.

As a result of cumulative effects of physical characteristics and the intense soil mechanization over the years, most lowland soils have a poor friability and a high density. This is aggravated by the commonly low amounts of organic matter: $71 \%$ of lowland soils have an organic matter content lower than 2.5\%, especially in the upper layer (Boeni et al., 2010; Rosa et al., 2011). From the physical point of view, these characteristics affect crop diversification in two distinct ways: when dry, planosols are dense, hard, crusted, and present a low capacity to supply water to plants, but when wet, the high adhesiveness makes them difficult to prepare with mechanical operations, hinders seeding, whereas the low levels of $\mathrm{O}_{2}$ in the root zone negatively affect rainfed plants and microorganisms. Other characteristics of wetland soils in the RS (especially the planosols-class) is the fast transition from dry to wet conditions. The window of time to implement soil operations is short, and these operations have to be completed as fast as possible by farmers. A good soil structure is one of the key-points to allow nonirrigated crops to perform well in the lowlands. A detailed analysis of methods used to reduce soil-related restrictions is provided by Marchesan (2016). Although short-term interventions (e.g. deep ploughing) are indispensable in many cases, in the longer term, soil-related 
restrictions should be managed with practises focussed on sustainability. Minimizing the dynamic changes in soil hydraulic status, increasing soil organic matter and reducing the intensity and frequency of soil preparation are some of the examples.

\section{Restrictions linked to soil fertility}

Planosols from south-Brazilian lowlands are characterised by a low to moderate soil fertility, in most instances with low organic matter content and P-deficiency (Pinto et al., 2004). When the soil is water-logged during the rice growing season, chemical reactions in the anaerobic environment increase soil $\mathrm{pH}$ and increase the solubility of nutrients. However, in a dry soil, part of the nutrients - especially P - are occluded, not able to be absorbed by plants (Silva et al., 2007). Due to the low organic matter content and the low soil fertility, the supply of nutrients to non-irrigated crops and pastures is primarily dependent on external sources, which increase production costs, the risk of environmental contamination and crop diseases (Jadoski et al., 2010; Andrade et al., 2012). This condition is aggravated by the acidic nature of the soils. Almost $80 \%$ of the area has extremely low $(<4.5)$ to low (4.5-5.5) $\mathrm{pH}$. Interestingly, correction of soil $\mathrm{pH}$ with liming is a method still not well incorporated in the routinely conducted management practices of the RS lowlands (Boeni et al., 2010).

Most crops and pastures cultivated in the planosols present very positive responses to high rates of fertilization, especially to $\mathrm{P}$ and $\mathrm{N}$. Considering that $56 \%$ of lowlands in RS are relatively poor soils, low fertility is sometimes regarded as a restriction for diversification of grain production in these areas. As stated, surface-irrigation in rice solubilize the nutrients, but this benefit from irrigation doesn't happen with non-irrigated crops. To overcome this constraint, lowland farmers can use a larger amount of nutrients in non-irrigated crops than is used in irrigated rice. In our view, other practices for soil management, such as a well-planned crop-livestock integration, no-tillage and use of cover crops, can contribute to improve soil fertility in a more sustainable way. These practises were therefore incorporated in the cropping systems which were evaluated in the research presented and discussed in the next chapters of this thesis. 


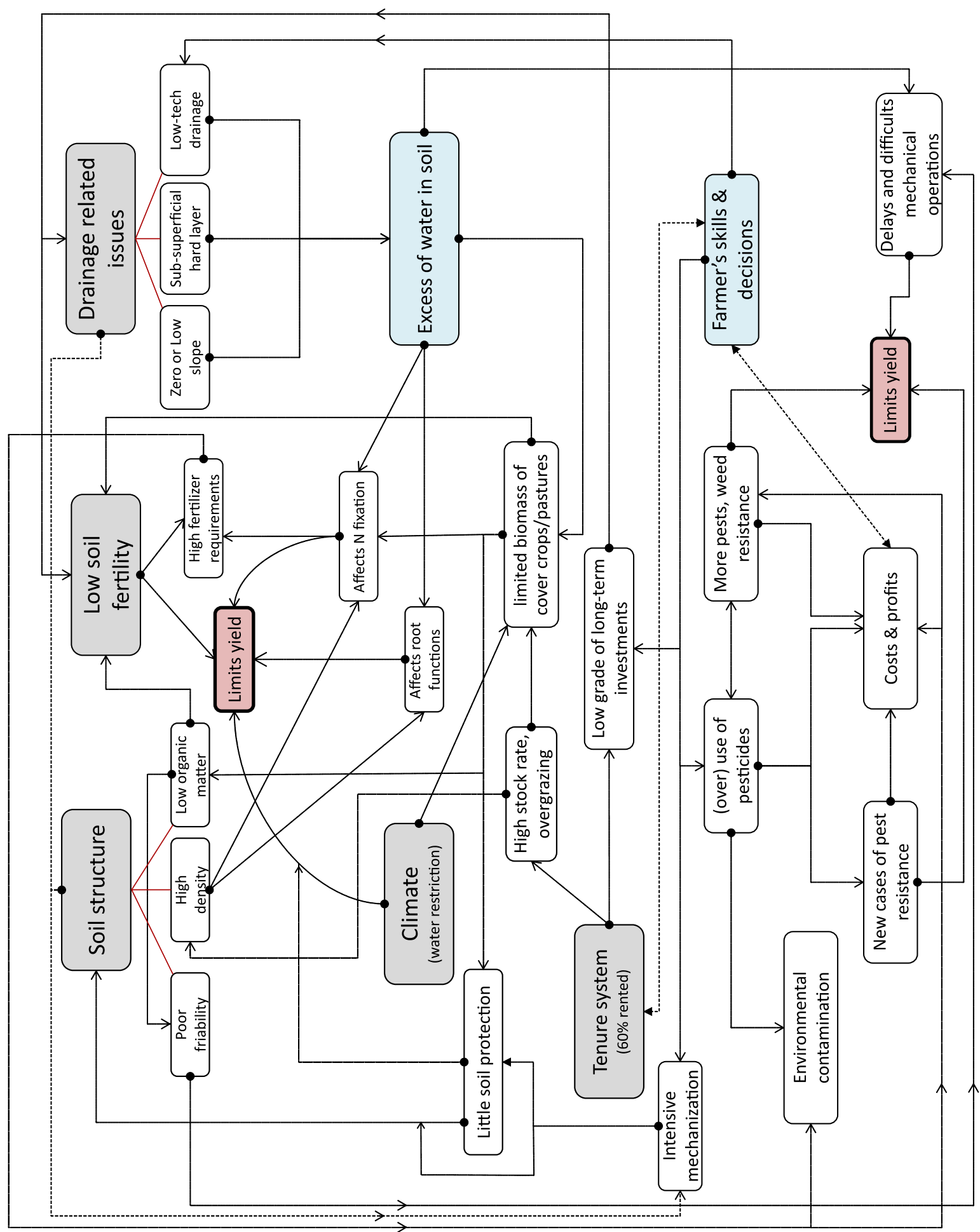

Figure 12. Main restrictions for crop diversification in the lowlands of south Brazil and their respective inter-relationships. 


\section{Drainage-related issues}

A severe limitation for diversification in lowland agriculture is presented by the difficulty of soil drainage. The planosols are almost flat and normally located in the lower part of the watersheds. These natural characteristics promote a very low surface runoff that accounts for the presence of groundwater near the soil surface. In cropping seasons with plenty of rain, some losses are expected to occur in rainfed crops due to temporary flooding. For crops like maize and soybean, even a temporary excess of soil moisture, like 3 days in flooding, is detrimental and can reduce grain yield, especially in case of maize (Ren et al., 2014; Kaur et al., 2017). Drainage-related restrictions to crop diversification in part of the lowlands in RS was increased when large areas were modified into zero-slope fields in the past, with the objective to crop rice in the pre-germinated system. This system reduced losses caused by weedy rice, but the complete soil levelling brought restrictions to crop diversification to an even larger area, due the inherent weak drainage capacity in this new condition.

As already mentioned, the planosols are characterized by a hard sub-superficial layer, almost impermeable, formed by clay eluviation. In the RS wetlands, this hard layer is one of main elements that prevents percolation and keeps free water and excess of moisture close to the soil surface. Excess of water has restricted the use of wetlands for crop diversification: it delays and complicates machinery operations, it affects the development of cover crops, pastures and grain crops, and it reduces $\mathrm{N}$ fixation in legumes and absorption of nutrients by roots (Figure 12). The construction of an efficient system of drainage would be the first measure to avoid water-excess associated losses on rainfed crops in the lowlands. It seems obvious, but it is not always observed in fields on which crop diversification is implemented. New farmers and those that experience rainfed crops for the first time can easily underestimate these risks. A lack of specific technologies for an efficient drainage is also apparent. Laser-guided levellers and tractor-pulled trenchers are being used for soil levelling and drying, but almost no other machinery is used for precision drainage in the RS lowlands. This technological gap spreads also into decision support systems. Except in a few demonstrative areas, modern techniques (for 2017) as 3D Laser mapping, airborne Lidar techniques (Light Detection and Ranging) or high precision, software-guided levelling or channelling construction, are almost absent in the lowlands of the extreme south Brazil. The positive point is that promising technologies for drainage (e.g., high-precision drainage maps coupled to DGPS-guided trenchers) are currently being tested in RS paddies and will probably become common practise in the near future.

Part of technological obsolescence in terms of the machinery used for drainage can be 
attributed to the historical regional specialization of producing irrigated rice, instead of rainfed crops. A substantial lack of investments in basic structures of drainage also originates from the relatively high costs to implement these techniques in large areas, and from the predominant tenure system. Even though the rental system has adequately facilitated rice-cattle integration, it has failed when long-term investments are required to put diversification in these fields. Construction of effective drainage systems, the correction of soil $\mathrm{pH}$ and the increase of specific nutrient levels are frequently object of disagreement between owners and renters (Vianna, 2012).

\section{Restrictions associated to climatic characteristics and other limitations}

The predominant climate in the southern half of RS consists of a precipitation higher than 60 $\mathrm{mm}$ in all months and an average daily temperature $>22^{\circ} \mathrm{C}$ in the warmer months (Alvares et $a l ., 2013)$. The balance between precipitation and evaporation in the summer months is, however, not always sufficient to supply rainfed crops with an appropriate amount of water. In RS, maize requires from 575 to $650 \mathrm{~mm}$ of water to complete a full cycle (Matzenauer et al., 1983; Bergamaschi et al., 2001) and this amount of water is even larger for soybean (Franke \& Dorfman, 2000). As the moisture accumulated into the soil during summer is normally around $540 \mathrm{~mm}$ (Figure 2-B), the probability of losses in rainfed crops due water deficit cannot be ignored. Use of cover crops for mulching can reduce the evaporative losses of the soil and improve water use efficiency, but the proportion of flat fields uniformly covered by crop residues in the lowlands is very limited. Ridge-based systems can contribute to alleviate this issue, since the permanent maintenance of a layer of residues on the soil surface is facilitated by these production models. Scientific assessments of the efficiency of cropping systems to convert water and solar radiation into biomass and food was included in evaluation of our longterm experiment.

Crop diversification in lowlands can also be affected by other factors, like the difficulties in integrated pest management, the high production costs, the poor economic results, the inherent limitations related to the renting system and even the lack of familiarity of farmers and rural workers with cropping systems other than irrigated rice. Fortunately, most of these harassments can be attenuated by providing correct information and training for farmers. As well illustrated by Bakhshi et al. (2016), the human capital (knowledge) is the most important factor associated to success in agricultural production enterprises; we believe the same is valid for the southern RS lowland farms. 


\subsection{Objective and research questions}

The broader objective of the research presented in this thesis is increase the knowledge about the basis of sustainability of the lowland production systems. There are several reasons for investigating sustainability of wetland agriculture. First, lowlands are strategic for the food security in Brazil: in a relatively small area ${ }^{9}$ almost $60 \%$ of the total energy intake of the Brazilian population (207 million) is produced. Second, food production per unit of land can be improved in the lowlands, and such improvements can diminish the pressure to expand the arable production at the cost of natural areas. Third, agricultural diversification has proven to increase the economic prosperity, employment and quality of life. Fourth, some of technologies unveiled in this work could not only benefit local systems and people, but also be used in other parts of the world, since lowlands across the globe share many similar characteristics.

Even though irrigated rice in south Brazil usually produces reasonable grain yields, the rice-based cropping systems have shown signals of fatigue and lack of sustainability. Currently, optimization of processes at field level and crop rotation are the common way to alleviate part of these problems. Indeed, crop rotation is practised in rice paddies, but in a limited area, confined to one single crop (soybean) and not without facing a number of limitations, as exposed in Figure 12. The current demand for agricultural products implies that these problems have to be solved fast, but the solutions also have to be sustainable, acceptable, feasible, marketoriented and economically viable. Identify how to intervene in the cropping systems (or even propose a new one) is the challenge that was at the basis of this thesis research.

Within this complex scenario, our work consisted of a long-term assessment of five distinct options for agricultural production in lowlands. The systems consisted of a traditional production model (rice-fallow), two modern rotation schemes (rice-soybean) and two innovative systems, based on large ridges (ridge-based). Each system was laid out on field scale, to be representative of what would be expected on real farms. Overall, this work was designed to better understand the basis of sustainability of these cropping systems.

When I drew the first sketches on how to obtain meaningful results from this large, timeand resource-consuming set of experiments, many questions came to my mind. The essence of these questions is listed in the next box:

\footnotetext{
${ }^{9}$ The 1.1 million ha of rice in the RS state represents just $1.7 \%$ of the acreage of food crops in Brazil (IBGE, 2017).
} 


\section{Box 2. The research questions}

1. How to design (new) production models for the lowlands, which fit the required needs of modern agriculture: sustainable, acceptable, feasible, market-oriented and economically viable?

2. How to compare different cropping systems in a fair and transparent way?

3. Is it possible to better comprehend production models at process level, similar to what engineers do, and on which processes should I focus to decompose these cropping systems in a meaningful way?

4. What is it that makes a system sustainable and which indicators should be used?

5. Which dimensions of sustainability should be included in this comparison?

6. Can practical improvements be suggested to overcome issues that are marked as unsustainable?

\subsection{Thesis outline}

This thesis consists of a general introduction (Chapter 1), four main research chapters addressing the research questions mentioned (Chapters 2 to 5) and a general discussion (Chapter 6). Below, the content of the various chapters is briefly introduced.

Chapter 2 - "The birth of a new cropping system: towards sustainability in sub-tropical lowland agriculture" describes a long term-experiment where five distinct cropping systems were evaluated in a lowland field in south Brazil. The cropping systems were compared with regional benchmarks, and a range of indicators related to field management, productivity and sustainability was measured and discussed. A description of how to establish these cropping systems in the field, as well as their outcomes from the agricultural and environmental perspectives, is provided. Special emphasis is given to the methods and results from the ridgebased systems, which are an innovation for the lowlands. This chapter is linked to research questions 1,2 and 4.

Chapter 3 - "Use of a multi-criteria approach to evaluate five agricultural cropping systems in lowlands" deepens into aspects like energy, labour and economic efficiencies in the cropping systems previously defined. The chapter also describes the creation and use of a framework to 
systematically analyse the five cropping systems consisting of Process Analysis and Key Performance Indicators. This method is inspired on a similar approach used in systems engineering and business intelligence. The outcomes of this method were used to elucidate strengths and weaknesses of the cropping systems, as well as to compare the systems by a ranking of their performance regarding five dimensions of sustainability - environmental, land use-efficiency, economics, energy-use and labour. This chapter is more associated to research questions 2,3 and 5 .

Chapter 4 - "A knife-roller effectively substitutes soil preparation by plough-and-harrow in lowland production systems" is connected to the last research question. It focusses on a technique to prepare lowland soils after the harvest of irrigated rice, and compares the traditional plough and harrow method with the performance of a heavy knife-roller. The alternative system is faster, independent of weather conditions and more beneficial than the plough-based method in terms of energy, labour requirement and monetary costs.

Chapter 5 - "Low disturbance seeding suppresses weeds in no-tillage soybean" describes an invention which consists of an apparatus attached into no-tillage seeders. This tool, named 'ski' because of its similarity with a snowing-ski, reduces soil disturbance and keeps the straw layer in the right place during crop seeding in no-tillage fields. The ski reduces weed germination and evidenced to potentially reduce herbicide consumption in no-tillage fields. This chapter is specially connected to the last research question, which addresses practical solutions to specific problems, thereby improving the sustainability of agricultural systems.

Chapter 6 is the General Discussion. It starts exploring the results in a distinct perspective than already presented in the individual chapters. Topics like the innovations summarized in the thesis, the use of land in the lowlands and some methodological aspects are discussed. An attempt to answer to "What makes a system sustainable...? is also presented, and an audacious exercise to establish a ranking of sustainability between the cropping system is showed. The last part presents an extrapolation for the expected impacts of two technologies unveiled in this work, in case of adoption by a number of farmers in the lowlands of south Brazil.

\subsection{References}

Alvares CA, Stape Jl, Sentelhas PC, de Moraes Goncalves JL \& Sparovek G (2013) Koppen's climate classification map for Brazil. Meteorologische Zeitschrift 22, 711728.

AndRade CFF, Niencheski LFH, Attisano KK, Milani MR, Santos IR \& Milani IC (2012) 
Fluxos de nutrientes associados às descargas de água subterrânea para a Lagoa Mangueira (Rio Grande do Sul, Brasil). Química Nova 35, 5-10.

Avila LA, MARChESAn E, SOUTO JdS \& SiQueIRA CA Interferência do arroz vermelho sobre o arroz irrigado. 1999 Congresso Brasileiro de Arroz Irrigado, Pelotas, Brazil, 594596.

BAKHSHI M, POURTAHERI M \& EFTEKHARI AR (2016) Developing a model to predict success of agricultural production enterprises based on their capitals. Journal of Agricultural Science and Technology 18, 1443-1454.

Ballini E, Nguyen TTT \& Morel JB (2013) Diversity and genetics of nitrogen-induced susceptibility to the blast fungus in rice and wheat. Rice $\mathbf{6}, 1-13$.

Barcellos JOJ, Filho LAQ, Ceolin AC, Gianezini M, McManus C, Malafaia GC \& OAIGEN RP (2011) Technological innovation and entrepreneurship in animal production. Revista Brasileira de Zootecnia 40, 189-200.

BATISTA IM \& SilveIRA VCP (2006) Influência das desigualdades econômicas regionais no setor agropecuário do Rio Grande do Sul. Revista Extensão Rural 13, 28-33.

Benetti MD (2007) Perspectivas de transformações estruturais na economia da Metade Sul do Estado. Indicadores Econômicos FEE 34, 129-142.

BERGAMASCHI H, RAdin B, Rosa LMG et al. (2001) Estimating maize water requirements using agrometeorological data. Estimativa das necessidades de água do milho através de dados agrometeorológicos. Revista argentina de agrometeorología. 1, 23-27.

BilenCA D \& MiÑARro F (2004) Áreas valiosas de pastizal - en las pampas y campos de Argentina, Uruguay y sur de Brasil., 1 edn. Fundación Vida Silvestre Argentina, Buenos Aires, Argentina.

Boeni M, ANGHINONi I, GENRO JR. SA \& OsóRIO FiLho BD (2010) Evolução da fertilidade dos solos cultivados com arroz no Rio Grande do Sul, (ed. Irga). IRGA/Estação Experimental, Cachoeirinha, RS, Brazil.

Borges BK (2016) RS in numbers: 2016, (ed. J Meneghetti). FEE-CIES, Porto Alegre, Brazil.

BRITTO FP, BARLETTA R \& MENDONÇA M (2006) Regionalização sazonal e mensal da precipitação pluvial máxima no estado do Rio Grande do Sul. Revista Brasileira de Climatologia 02, 35-51.

Carvalho PCDF \& Batello C (2009) Access to land, livestock production and ecosystem conservation in the Brazilian Campos biome: The natural grasslands dilemma. Livestock Science 120, 158-162.

Cassol GV, Marchesan E, Robaina AD, Trivisiol Vs, Tessele JP, Aramburu BB \& FILLIPIN J Sistemas de implantação e irrigação para o cultivo da soja em áreas de arroz. 2015 Congresso Sul Brasileiro de Arroz Irrigado, Pelotas, RS, Brazil.

CHHOKAR RS, SHARMa RK, Gathala MK \& PUNDiR AK (2014) Effects of crop establishment techniques on weeds and rice yield. Crop Protection 64, 7-12.

Comissão de QuímicA E Fertilidade do Solo - RS/SC (2004) Manual de Adubacao e Calagem para os Estados do Rio Grande do Sul e de Santa Catarina, (ed. SBDCD SoloCqfs), 2 edn. SBCS-CQFS, Porto Alegre.

Coronel DA, Alves FD \& Silva MAE (2007) Notas sobre o processo de desenvolvimento da metade sul e norte do estado do Rio Grande do Sul: uma abordagem comparativa. 
Perspectiva Econômica 3, 27-43.

Counce P, Keisling T \& Mitchell A (2000) A uniform, objective, and adaptive system for expressing rice development. Crop Science 40, 436-443.

CRUZ RC \& GUADAGNIN DL (2012) Uma pequena história ambiental do Pampa: proposta de uma abordagem baseada na relação entre Perturbação e mudança. In: A sustentabilidade da Região da Campanha-RS: práticas e teorias a respeito das relações entre ambiente, sociedade, cultura e políticas públicas., Vol. 1, 226. UFSM, Santa Maria, RS, Brazil.

CunHA GR (2001) El Niño-Southern Oscillation and climate forecasts applied to crops management southern Brazil. In: Applications of climate forecasting for better decisionmaking processes in agriculture. (eds GR Cunha, JC Haas \& MA Berlato), 181-202. Embrapa Trigo, Passo Fundo, Brazil.

DARWIN C (1845) Journal of Researches Into the Natural History and Geology of the Countries Visited During the Voyage of H.M.S. Beagle Round the World: Under the Command of Capt. Fitz Roy. J. Murray.

Dill MD, Emvalomatis G, SaAtKamp H, Rossi JA, Pereira GR \& Barcellos JOJ (2015) Factors affecting adoption of economic management practices in beef cattle production in Rio Grande do Sul state, Brazil. Journal of Rural Studies 42, 21-28.

EMATER RS (2015) Informações Agropecuárias. Available at: http://www.emater.tche.br/site/servicos/informacoes-agropecuarias.php (accessed 12 Dec 2015).

EPAGRI (2015) Histórico da produção de arroz irrigado em SC. Available at: http://www.epagri.sc.gov.br/?page_id=1343 (accessed 13 Jun 2017).

Faccio Carvalho PC, Anghinoni I, Moraes A et al. (2010) Managing grazing animals to achieve nutrient cycling and soil improvement in no-till integrated systems. Nutrient Cycling in Agroecosystems 88, 259-273.

FEIX RD \& Leusin JR. S (2015) Painel do Agronegócio no Rio Grande do Sul - 2015., Vol. 1. (ed Fee), 1 edn, 44. FEE, Porto Alegre, RS, Brazil.

Filipe BK, Celio I C, Guilhem M, Esteban A P \& OsCar J S (2013) Desplazamiento de la ganadería por la agricultura en una cuenca de La Pampa ondulada: Efectos sobre el escurrimiento superficial y erosión hídrica. Ciencia del suelo 31, 83-92.

FINGER MIF \& WAQUIL PD (2013) Percepção e medidas de gestão de riscos por produtores de arroz irrigado na Fronteira Oeste do Rio Grande do Sul. Ciencia Rural 43, 930-936.

FocheZATTO A \& GHINIS CP (2012) Estrutura produtiva agropecuária e desempenho econômico regional: o caso do Rio Grande do Sul, 1996-2008. Revista de Economia e Sociologia Rural 50, 743-762.

FRANKE AE \& DORFMAN R (2000) Necessidades de irrigação suplementar em soja nas condições edafoclimáticas do Planalto Médio e Missões, RS. Pesquisa Agropecuária Brasileira 35, 1675-1683.

GAN Y, SidDiQue K, TURNER N et al. (2013) Ridge-Furrow Mulching Systems-An Innovative Technique for Boosting Crop Productivity in Semiarid Rain-Fed Environments. Advances in Agronomy, Vol 118 118, 429-476.

GARRITY DP, GINES HC \& No (1990) The development of rice-corn rotations in tropical lowland environments: a systems research approach. In: Extension Bulletin - ASPAC, 
Food \& Fertilizer Technology Center, Vol. 316, 24p. IRRI, Manila, Philippines.

Gomes AdS, Petrini JA \& FAgUndes PRR (2004) Manejo racional da cultura do arroz irrigado "Programa Marca", (ed. PRR Fagundes). Embrapa Clima Temperado, Pelotas, Brazil.

Gomes AdS, Silva CASd, Parfitt JMB, PAuletto EA \& Pinto LFS (2006) Caracterização de indicadores da qualidade do solo, com ênfase às áreas de várzea do Rio Grande do Sul. Documentos 169, 40

Goulart ICGR, Borba TCO, Menezes VG \& Merotto A (2014) Distribution of weedy red rice (Oryza sativa) resistant to imidazolinone herbicides and its relationship to rice cultivars and wild Oryza species. Weed Science 62, 280-293.

HADLER EC \& OTERo DT (2008) Actas: a Classe Rural Resgatando as Raízes da Sua História, (ed. E Textos), Pelotas, RS, Brazil.

HASENACK H, Weber E, BoldRini II \& TREVISAN R (2010) Mapa de sistemas ecológicos da ecorregião das Savanas Uruguaias em escala 1:500.000 ou superior e relatório técnico descrevendo insumos utilizados e metodologia de elaboração do mapa de sistemas ecológicos. In: Projeto IB/CECOL/TNC, Vol. 1, 22. UFRGS-Centro de Ecologia-The Nature Conservancy, Porto Alegre, Brazil.

IBGE (2016) Banco de Dados Agregados (Aggregated Database). Available at: http://www.sidra.ibge.gov.br/ (accessed 05 Jan 2017).

IRGA (2006) Censo da lavoura de arroz irrigado do Rio Grande do Sul - safra 2004/05.

IRGA (2015) Safra 2013/14 Sistemas de cultivo (Season 2013/14 - Rice Crop Systems). Available at: http://www.irga.rs.gov.br/upload/20140225133041sistema_cultivo_ 13_14_ii.pdf (accessed 14 Jan 2015).

IRGA (2017) Services and Informations - Cropping Seasons. Available at: http://www.irga.rs.gov.br/conteudo/4215/safras (accessed 05 Jan 2017).

JAdOSKi SO, SAito LR, PRAdo CD, LOPES EC \& SALES LLSR (2010) Characteristics of the nitrate leaching in intensive farming areas. Applied Research \& Agrotechnology 3, 193200 .

KANG TH, BERNARDini R, JR. MVW \& AFFELDT B (2014) O novo Índice de Desenvolvimento Socioeconômico (Novo Idese): aspectos metodológicos. (ed Fee), 20. Fundacao de Economia e Estatistica, Porto Alegre, Brazil.

Kaur G, Zurweller BA, Nelson KA, Motavalli PP \& Dudenhoeffer CJ (2017) Soil waterlogging and nitrogen fertilizer management effects on corn and soybean yields. Agronomy Journal 109, 97-106.

LOUZADA JA, CAICEDO N \& HELFER F (2008) Condições de drenagem relacionadas ao trânsito de máquinas em solo de várzea (RS-Brasil). Revista Brasileira de Engenharia Agricola e Ambiental 12, 98-105.

MARCHESAN E (1994) Arroz vermelho: caracterização, prejuízos e controle. Ciencia Rural 24, 423-429.

MARCHESAN E (2016) Desenvolvimento de tecnologias para cultivo de soja em terras baixas. Revista Eletronica Competências Digitais para Agricultura Familiar 2, 4-19.

MARIOT CHP, VIEIRA VM \& MENEZES VG (2009) Práticas de manejo integradas para produção de arroz irrigado. Pesquisa Agropecuária Brasileira 44, 243-250. 
MARTIN G, Moraine M, RYSCHAWY J et al. (2016) Crop-livestock integration beyond the farm level: a review. Agronomy for Sustainable Development 36, 53.

MARTins JD, Bohrz IS, TURA EF, Fredrich M, Veronez RP \& KunZ GA (2016) Assessment of area irrigated by center pivot in state of Rio Grande do Sul. Irriga. Brazilian journal of irrigation and drainage 21, 300-311.

Matzenauer R, Westphalen SL \& Bergamaschi H (1983) Relações entre a evapotranspiração do milho e as fórmulas de Penman e Thornthwaite. Pesquisa Agropecuária Brasileira 18, 1207-1214.

Menezes VG, Anghinoni I, Silva PRF et al. (2012) Projeto 10: estratégias de manejo para aumento da produtividade e da sustentabilidade da lavoura de arroz irrigado do RS: avanços e novos desafios., (ed. Irga). Instituto Riograndense do Arroz, Porto Alegre, Brazil.

Menezes VG, Mariot CHP, KAlsing A \& Goulart ICGR (2009) Arroz-vermelho (Oryza sativa) resistente aos herbicidas imidazolinonas. Planta Daninha 27, 1047-1052.

Modernel P, Rossing WAH, Corbeels M, Dogliotti S, Picasso V \& Tittonell P (2016) Land use change and ecosystem service provision in Pampas and Campos grasslands of southern South America. Environmental Research Letters 11, 113002.

Nabinger C, Ferreira ET, Freitas AK, Carvalho PCDF \& Sant'Anna DM (2009) Produção Animal com base no campo nativo: aplicação de resultados de pesquisa. In: Campos Sulinos - conservação e uso sustentável da biodiversidade, Vol. 1. (eds VDP Pillar, SC Müller, ZMDS Castilhos \& AVÁ Jacques), 403. MMA, Brasilia, Brazil.

NARDIN DD \& RoBAINA LEDS (2010) Zoneamento geoambiental no oeste do Rio Grande do Sul: um estudo em bacias hidrográficas em processo de arenização. Sociedade \& Natureza 22, 487-502.

Ofstehage A (2016) Farming is easy, becoming Brazilian is hard: North American soy farmers' social values of production, work and land in Soylandia. The Journal of Peasant Studies 43, 442-460.

Oliveira TED, Freitas DSD, GiAnezini M et al. (2017) Agricultural land use change in the Brazilian Pampa Biome: The reduction of natural grasslands. Land Use Policy 63, 394400 .

PAIVA CÁN (2008) Por que alguns municípios gaúchos crescem tanto e outros tão pouco? Um estudo sobre a evolução das desigualdades territoriais no RS entre 1970-2000. Texto para Discussão FEE.

Pillar VdP, Müller SC, Castilhos ZMdS \& Jackes AVdÁ (2009) Campos Sulinos Conservação e uso sustentável da biodiversidade. Brazilian Ministry of Environment (MMA), Brasília, Brazil.

Pinto JJO, Noldin JA, Rosenthal MD et al. (2009) Atividade residual de (imazethapyr+imazapic) sobre azevém anual (Lolium multiflorum), semeado em sucessão ao arroz irrigado, sistema Clearfield ${ }^{\circ}$. Planta Daninha 27, 609-619.

Pinto LFS, Laus Neto JA, Pauletto EA \& Gomes AS (2004) Solos de várzea do Sul do Brasil cultivados com arroz irrigado. In: Arroz irrigado no sul do Brasil, Vol. 21, 75-96. Embrapa Clima Temperado, Pelotas, RS, Brazil.

PINTO NGM \& CORONEL DA (2016) Desenvolvimento rural no Rio Grande do Sul: uma análise das mesorregiões entre 2000 e 2010. Ensaios FEE 36, 893-920. 
Porto MP, Sulva CASD \& PARFITT JMB (2004) Diversificação do sistema de produção de arroz irrigado com cultivos anuais. In: Manejo Racional da Cultura do Arroz Irrigado, Vol. 1. (eds ADS Gomes, JA Petrini \& PRR Fagundes), 1 edn, 153-168. Embrapa Clima Temperado, Pelotas, Brazil.

PuCHALSKY LA (2000) Efeitos associados ao El Niño e La Niña na temperatura média, precipitação pluvial e no déficit hídrico no Estado do Rio Grande do Sul. Master Thesis, Universidade Federal do Rio Grande do Sul, Porto Alegre, RS, Brazil.

Qi W, Xiang R, Xingyang S, Guangrong H, Enhe Z, Heling W \& Vance MM (2015) The optimum ridge-furrow ratio and suitable ridge-covering material in rainwater harvesting for oats production in semiarid regions of China. Field Crops Research 172, 106-118.

Ren B, Zhang J, Li X, FAn X, Dong S, LiU P \& Zhao B (2014) Effects of waterlogging on the yield and growth of summer maize under field conditions. Canadian Journal of Plant Science 94, 23-31.

Rocha JM (2011) As Raízes da Crise da Metade Sul. Estudo da formação econômica do Rio Grande do Sul, (ed. Unipampa), 1 edn. Fundação Universidade Federal do Pampa, Jaguarão, RS, Brazil.

Rosa CMd, Castilhos RMV, Pauletto EA, Pillon CN \& Leal OdA (2011) Conteúdo de carbono orgânico em planossolo háplico sob sistemas de manejo do arroz irrigado. Revista Brasileira de Ciencia do Solo 35, 1769-1776.

Roso AC, JR AM, Delatorre CA \& Menezes VG (2010) Regional scale distribution of imidazolinone herbicide-resistant alleles in red rice (Oryza sativa L.) determined through SNP markers. Field Crops Research 119, 175-182.

Ruviaro CF, da Costa JS, Florindo TJ, Rodrigues W, DE Medeiros GIB \& VAsconcelos PS (2016) Economic and environmental feasibility of beef production in different feed management systems in the Pampa biome, southern Brazil. Ecological Indicators 60, 930-939.

SANTOS HD, JACOMINE PKT, ANJOS LD et al. (2006) Sistema brasileiro de classificação de solos.

Sartori GMS, Marchesan E, Azevedo CF, Streck NA, Roso R, Coelho Ll \& Oliveira MLD (2013) Grain yield and water use efficiency in irrigated rice according to sowing date. Ciencia Rural 43, 397-403.

SCHNEID L (2009) Zona Sul atrai agricultores da Metade Norte (South Zone attract farmers from North Half). In: Correio do Povo, Vol. Year 114 n. 273, 273 edn. Correio do Povo, Porto Alegre, Brazil.

SCHOLles D \& VARGAS LK (2004) Viabilidade da inoculação de soja com estirpes de Bradyrhizobium em solo inundado. Revista Brasileira de Ciencia do Solo 28, 973-979.

SEKAR I \& PAL S (2012) Rice and wheat crop productivity in the Indo-Gangetic Plains of India: Changing pattern of growth and future strategies. Indian Journal of Agricultural Economics 67, 15.

SiLVA LSD, RANNO SK \& MALLMANN FJK (2007) Fracionamento do fósforo inorgânico em solos de várzea do Rio Grande do Sul. Current Agricultural Science and Technology $13,47-54$.

Silva Neto B \& Frantz TR (2003) Dinâmica da agricultura e desenvolvimento no Rio Grande do Sul. Revista de Economia e Sociologia Rural 41, 97-115. 
SiLVEIRA VCP, GONZÁLEZ JA \& FonSECA ELD (2017) Land use changes after the period commodities rising price in the Rio Grande do Sul State, Brazil. Ciencia Rural 47.

SÓRIO JR. H (2001) A ciência do atraso: índices de lotação pecuária no Rio Grande do Sul. UPF (Universidade de Passo Fundo), Passo Fundo, Brazil.

SOSBAI (2014) Arroz irrigado: recomendações técnicas da pesquisa para o sul do Brasil, (ed. Sosbai), 1 edn. Sociedade Sul Brasileira de Arroz Irrigado, Santa Maria, RS, Brazil.

SOSMA (2015) Atlas dos remanescentes florestais da mata atlântica período 2013-2014. Relatório Tecnico.

Streck EV, Kämpf N, Dalmolin RSD et al. (2008) Solos do Rio Grande do Sul. $2 a$ Ed. UFRGS, Departamento de Solos, Faculdade de Agronomia and EMATER/RS, Porto Alegre, RS, Brazil.

THEISEN G \& BiANCHi MA (2009) Diagnóstico sobre o uso de agroquímicos em soja - safra 2003/2004. (Diagnosis about agrochemical use in soybean - 2003/04 season). In: Resultados de pesquisa: Controle de Plantas Daninhas 1993 a 2008., Vol. 1. (ed MA Bianchi), 392-397. Fundacep, Cruz Alta, RS, Brazil.

USDA (2017) United States Department of Agriculture - Foreign Agricultural Service. Available at: https://www.fas.usda.gov/commodities/livestock-and-meats (accessed 12 March 2017).

VERNETTI FJ \& VERNETTI JR. FJ (2013) Histórico da pesquisa de soja na região sudeste do Rio Grande do Sul: várzeas e coxilhas (do IAS à ETB), (ed. FDJ Vernetti Jr.). Embrapa Clima Temperado, Pelotas, RS, Brazil.

Vianna ML (2012) Extremo Sul do Brasil: um lugar esquecido. Editora Textos, Pelotas, RS, Brazil.

Villa SCC, Marchesan E, Avila LA, Massoni PFS, Telo GM, Machado SLO \& Camargo ER (2006) Arroz tolerante a imidazolinonas: controle do arroz-vermelho, fluxo gênico e efeito residual do herbicida em culturas sucessoras não-tolerantes. Planta Daninha 24, 761-768.

Ziska LH, GEALY DR, Burgos N et al. (2015) Weedy (Red) rice. An emerging constraint to global rice production. In: Advances in Agronomy, Vol. 129, 181-228. 



\section{Chapter 2}

\section{The birth of a new cropping system}

Article published in Field Crops Research 212C (2017) pp. 82-94.

doi:10.1016/j.fcr.2017.07.001.

Title: The birth of a new cropping system: towards sustainability in the sub-tropical lowland agriculture.

Giovani Theisen*; Júlio José Centeno da Silva*; Jamir Silva da Silva*; André Andres*; Niels P.R.Anten $\dagger$; Lammert Bastiaans $\dagger$

* Embrapa Temperate Climate, BR 392, km 78, 96010-970, Pelotas, RS, Brazil.

$\dagger$ Centre for Crop System Analysis, Wageningen University, Wageningen, Netherlands 


\title{
The birth of a new cropping system: towards sustainability in the sub-tropical lowland agriculture
}

Giovani Theisen*†; Júlio Jose Centeno da Silva*; Jamir Silva da Silva*; André Andres*; Niels P.R. Anten†; Lammert Bastiaans $\dagger$

* Embrapa Temperate Climate, BR 392, km 78, 96010-970, Pelotas, RS, Brazil

$\dagger$ Centre for Crop System Analysis, Wageningen University, Wageningen, Netherlands

\begin{abstract}
Developing cropping systems that meet multiple demands of high production, resource-use efficiency and low ecological footprint is a major global challenge. In Southern Brazilian lowlands, irrigated rice (Oryza sativa L.) in combination with fallow for beef production is the dominant cropping system. This system is key to Brazilian food security but faces problems of resource use efficiency, soil preservation and greenhouse gas emissions typically associated to rice irrigation. In this research, a multi-criteria analysis of the usual rice-fallow system, and a number of alternative production schemes - i.e., the more recent rice-soybean (Glycine $\max$ (L.) Merr.) rotations and the newly developed systems based on large ridges, was made. The latter is based on the construction of large ridges ( $8 \mathrm{~m}$ width) on which rainfed maize (Zea mays L.) and soybean, conducted in no-tillage, are integrated with either beef-livestock production or cover crops in winter. This study was done in an experiment that lasted for nine years. The five cropping systems were managed as independent fields and a range of indicators related to crop management, productivity and sustainability was measured. The Rice-Fallow system required the lowest amount of energy, but it had the lowest energy use efficiency and highest carbon-based environmental footprints, when expressed as greenhouse gasses emitted per $\mathrm{kg}$ of food produced. The rice-soybean rotation system presented an improved performance for the carbon-based footprints in comparison to the rice-fallow system. Within rice-soybean rotation, using minimum-tillage instead conventional tillage increased the overall carbon balance and the carbon sequestered into the soil as organic matter. Most strikingly, the new ridge-based systems exhibited the most favourable values for many of the indicators. The more diverse rotation system, and particularly the extension of the growing season to winter, resulted in improvements in soil quality, biomass production and carbon sequestration into the soil. Water- and light- use efficiency were increased, whereas greenhouse gas emissions reduced. The ridgebased crop-livestock integration offered the best balance between food production and environmental preservation. This cropping system is potentially one of best alternatives to increase agricultural diversification and sustainability in the sub-tropical lowlands such as in southern Brazil. This shows that modifications of cropping systems can result in major simultaneous improvements in yield, resourceuse efficiency and ecological sustainability.
\end{abstract}

Keywords: crop rotation, farming system, sustainability indicators, soil management, wetland 


\subsection{Introduction}

Current cropping systems are under an increased pressure of producing more food with less inputs and to combine this high efficiency with the smallest possible negative impact on the environment (Brentrup et al., 2004; Schipanski et al., 2014). Engineering systems that meet these multiple demands is complex, particularly for agriculture in sensitive environments, like the lowlands (Durno et al., 1992). The lowlands in sub-tropical South America comprise important agricultural production systems, a large repository of freshwater and wild life. In the south of Brazil the lowlands cover a total area of 6 million hectares. Next to the environmental services provided by the natural landscapes, food production, an important additional ecosystem service, is provided through agriculture. Approximately eighty percent of rice, the main food of the Brazilian population, is produced under surface irrigation in the temperate lowlands in the south of Brazil.

Irrigated rice has been the main crop in the lowlands of south Brazil for more than a century. Rice is cultivated in 1.2 million hectares yearly, but a large part of the anthropic lowlands commonly remains fallow, or are destined for extensive beef-cattle production. The most common soils in this environment, gleysols and planosols, are characterized by poor drainage and a high bulk density (Lima et al., 2009). These conditions make the fields well suited for irrigated rice production, but form serious restrictions for species which do not tolerate waterlogging. As a result, rice is the main crop, and usually even the sole crop, in the agricultural systems of the lowlands.

There is however no doubt that alternation of irrigated rice with other crops bears positive implications for sustainability of the lowland agro-ecosystems (Komatsuzaki \& Ohta, 2007; Hokazono \& Hayashi, 2015). Crop rotation helps reduce weed problems (Erasmo et al., 2004; Andres et al., 2012) and increases soil quality (Everaarts et al., 2015). In addition, emissions of methane and other greenhouse gasses, typical for irrigated rice, can be reduced with crop rotation in lowlands (Nishimura et al., 2011; Weller et al., 2016). Despite the advantages of more diversified cropping systems and the high demand for grains other than rice in local and international markets, the use of crop rotation is not widely practiced in the wetlands. Currently, less than one-third of irrigated rice in south Brazil is rotated with other grain crops, mostly with soybean (IBGE, 2015). Also winter cover crops, like black oat, forage radishes and vetches (Avena strigosa, Raphanus sp. and Vicia sp., respectively), species which provide relevant environmental services for agricultural systems in the uplands (Schipanski et 
al., 2014; Teixeira et al., 2016), hardly adapt to the typical soil conditions in lowlands and are therefore almost absent. Obviously, the only way to create conditions that would support more diversified systems is by removing the inherent restrictions of hydromorphic soils for growing other crops. One alternative in this sense is the establishment of large ridge based systems (Figure 1), where the alternation of ridges and small channels create a drier environment, well suited for the production of crops that do not tolerate waterlogging, as well as the introduction of cover crops during winter time. Due to the large area under fallow in the south Brazilian lowlands, introduction of such novel systems does not necessarily compete for land with the current rice production systems.

Identification of the most adequate cropping system for the lowlands, which would simultaneously achieve economic, environmental and technical demands, is an intricate task. Some production oriented, short-term studies indicated technical advantages of crop rotation and integrated crop-livestock systems over mono-crop models (Balbinot Junior et al., 2009; Vernetti Junior et al., 2009; Ferreira et al., 2014). However, long-term studies, in which sustainability is assessed from an integrated perspective and addressing a wide range of criteria, are missing. Such studies are required to capture differences that only become apparent in the long run, and also would prevent that erratic short-time events, like a drought in a specific cropping season, would distort the analysis. Considering that lowlands are one of the most attractive new frontiers for rainfed crops in southern Brazil (Feix \& Leusin Jr., 2015) and elsewhere (Durno et al., 1992), a critical analysis of current and alternative cropping systems is an important step for identifying how to best equilibrate increased food production with environmental preservation.

In this research, we analysed three rice-based cropping systems and two novel ridgebased production models implemented in the Brazilian temperate lowlands. For the rice-based models, the systems were distributed in a coherent range of configurations: one simple model (rice-fallow) plus two more elaborated systems (rice-soybean in conventional and minimum till). In addition, the ridge-based models represent two feasible alternatives: both contained summer rainfed grain crops, with one model prioritizing winter cover crops and the second focusing on crop-livestock integration. During nine consecutive years, data were collected in these cropping systems, which were composed by farm-size plots located side-by-side within an experimental station. For each of the cropping systems, indicators reflecting a range of aspects related to field and crop management, productivity and sustainability were assessed and analysed. 


\subsection{Material and Methods}

\section{Site description}

This study was conducted in the Lowlands Experimental Station (LES), which belongs to Embrapa (Brazilian Agricultural Research Corporation), near Pelotas, in Rio Grande do Sul (RS state), southern Brazil (31.8134 S; 52.4736 W). The experiment started in May 2006, when five cropping systems were established in a uniform 33-ha area inside LES. This field had been maintained in fallow with spontaneous vegetation since 2000, and cultivated with irrigated rice in the 2004/05 and 2005/06 cropping seasons. The terrain is flat, at $13 \mathrm{~m}$ above sea level and the soil is classified as Solodic haplic eutrophic Planosol, belonging to the Pelotas mapping unit (Streck et al., 2008). A soil analysis just prior to the start of the experiment indicated an average soil bulk density of $1.49 \mathrm{~kg} \mathrm{dm}^{-3}$ and a composition of $283 \mathrm{~g} \mathrm{dm}^{-3}$ clay, $551 \mathrm{~g} \mathrm{dm}^{-3}$ silt and 608 $\mathrm{g} \mathrm{dm}{ }^{-3}$ sand. The climate is humid temperate ( $\mathrm{Cfa}$, according to Köppen's classification (Alvares et al., 2013)), with an average temperature of $17.8^{\circ} \mathrm{C}$ and yearly precipitation of 1367 mm.

The five production systems, for which a description is included below, varied in size between 3.1 and 11.0 hectares. The size varied due the permanent structure (roads, channels, fences) in the experimental station. The names of cropping systems and the essential characteristics are, noting that systems $d$ and e are novel:

a) Rice and fallow ("Rice-Fallow"): dry-seeded irrigated rice with minimum-till soil management, cultivated for three consecutive cropping seasons, followed by a three-year interval without rice. During part of this fallow period, cattle for meat production occupied the fields $\left(1.1\right.$ head ha $\left.\mathrm{h}^{-1}\right)$. This model of rice production, with small variations, is currently being used in the largest part of the lowlands in the RS state.

b) Rice and soybean, cultivated in conventional tillage ("Rice-Soybean CT"): dry-seeded irrigated rice cultivated for two consecutive cropping seasons, followed by two seasons of rainfed soybean. In the last cycle rice was repeated for three seasons. Main soil preparation using plough and harrow was performed in winter. In the next spring, just prior to seeding of the summer crop, one additional harrowing was conducted as seedbed preparation.

c) Rice and soybean, cultivated in minimum tillage ("Rice-Soybean MT"): The same as (b) but soil preparation was performed immediately after rice harvest; the soil was not 
prepared after harvesting soybean. Crops were seeded with a no-tillage seeder, after herbicidal control of spontaneous vegetation using glyphosate.

d) Rainfed crops integrated with beef-livestock, placed over large-based ridges ("Ridges and Cattle"): soybean and maize were cultivated sequentially (one crop per summer season) in no-tillage, on permanent large ridges $(8.0 \mathrm{~m}$ wide and $0.4 \mathrm{~m}$ high in the center (Figure 1)), constructed in mid-2006. In the winter seasons, the field was cultivated with pastures composed of Italian ryegrass (Lolium multiflorum Lam.) and black oats (Avena strigosa Schreb.). Beef cattle was placed on the pastures in winter, at a stocking rate adjusted to maintain a forage allowance of $12 \%$; i.e. $12 \mathrm{~kg}$ of dry mass (DM) per $100 \mathrm{~kg}$ of cattle weight per day. Herbicidal control of the remaining vegetation was performed before seeding soybean and maize.

e) Rainfed crops integrated with cover crops, placed over large-based ridges ("Ridges and Cover crops"): the same as (d) except that during winter time the field was cultivated with cover crops (a mix of Italian ryegrass, black oats, hairy vetch (Vicia sativa L.) and radish (Raphanus sativus L.)), and, that in the last two cycles, beef cattle were placed at low density (forage allowance of $24 \%$ ) on the cover crops.

All crops followed the regional standards for crop and pest management, using fertilizers, pesticides and critical levels of control according to the guidelines provided by SOSBAI (2014) for rice, Reunião... (2013) for maize, and Embrapa (2012) for soybean.

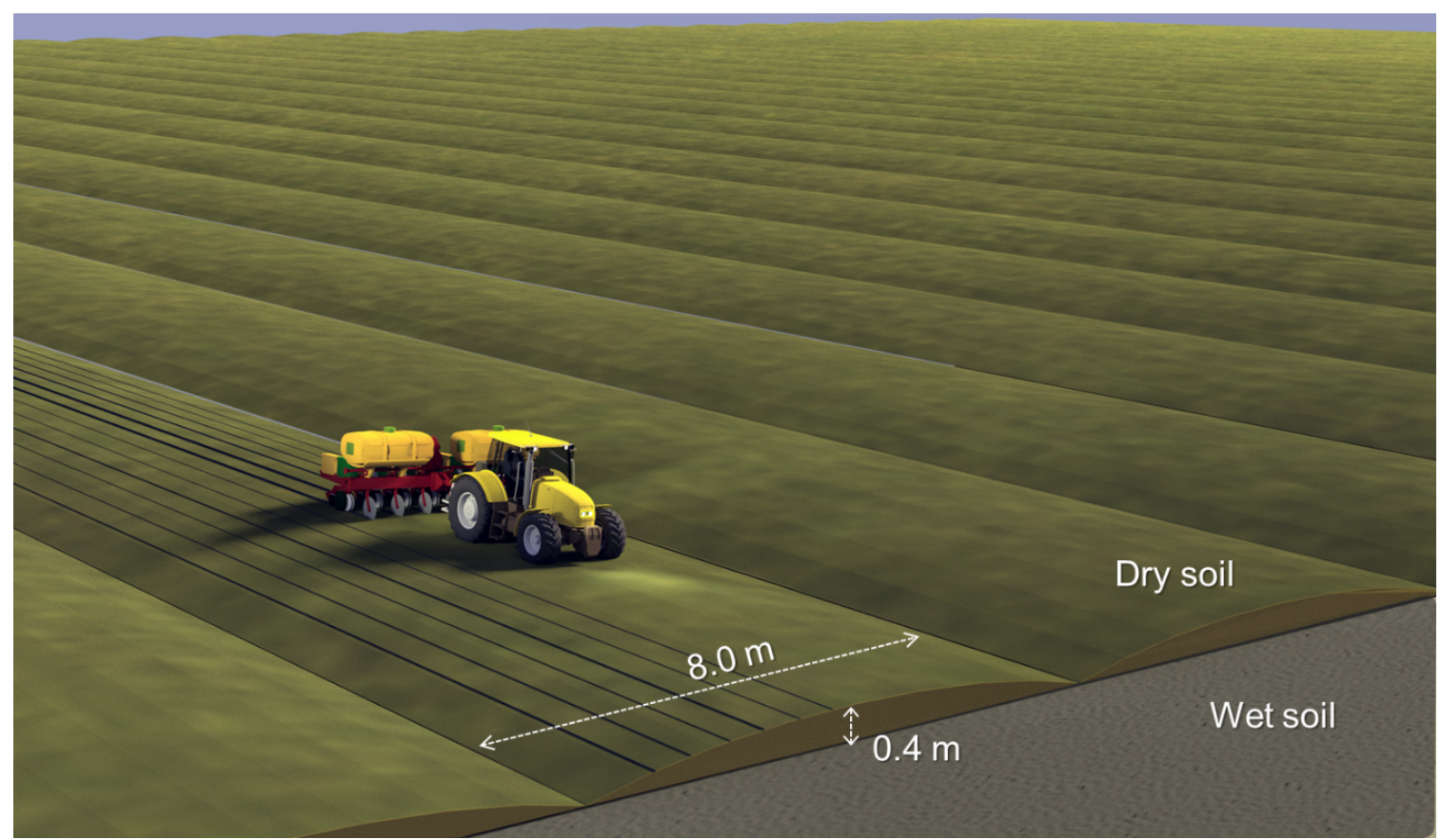

Figure 1. Simplified drawing of a lowland field conducted with large ridges. 


\section{Data acquisition}

\section{Soil quality and climatic data}

The soil of each plot was first analysed in May 2006, before the initiation of the treatments. Final soil analysis was done in August 2015, when twelve samples were collected in each cropping system. Climatic data were provided by a meteorological station located within the LES. For the timespan of the experiment, daily values of minimum and maximum temperature, precipitation and solar radiation were recorded.

\section{Grains, plant biomass and beef-cattle production}

Grain yield was assessed by collecting samples of crops (hand harvested) just before combine harvesting. Individual sample size varied between $6.0 \mathrm{~m}^{2}$ (rice) to $20.4 \mathrm{~m}^{2}$ (maize and soybean). The number of samples per crop in a season was on average 14, attaining to 40 samples in some years. The samples were threshed in an electrical threshing machine. Grain moisture was evaluated in an automatic analyser and the yield was standardized to $13 \%$ moisture for all crops.

The biomass of aerial parts of crops, cover crops, pastures and spontaneous vegetation was measured by collecting eight samples per system at the end of both winter and summer seasons, with an individual sample area of $2.25 \mathrm{~m}^{2}$. Biomass was dried at $60^{\circ} \mathrm{C}$ for 2 days before weighing. Root biomass was estimated as $20 \%$ of total dry mass (Poorter et al., 2012). Seed production from cover crops and spontaneous vegetation was assessed by collecting shattered seeds, using 15 units $\mathrm{ha}^{-1}$ of 12-cm diameter dishes, randomly distributed in each cropping system. The seeds were dried at $60^{\circ} \mathrm{C}$ for 2 days before weighing.

Cattle production was evaluated by weighing each livestock unit on the days of entry and exit from the fields. The herd was composed of 1.5 to 2 year old steers and heifers of Charolaise breed. Production of cattle manure (dung + urine) was assumed as $6 \%$ of cattle live weight per day (Santos \& Nogueira, 2012). Composition of nutrients in manure, as well as the nutrients exported by grains and cattle live weight, were calculated using standard values from the technical manual of soil fertility and fertilizers for southern Brazil (Comissão de Química e Fertilidade do Solo - RS/SC, 2004).

\section{Data about field operations}

All field procedures and machinery used were equivalent to that used in commercial farms. A scheme of field management for all cropping systems is presented in the Item $B$, in the 
Supplementary Information section. The data collected were: a) the time to achieve each field operation; b) the fuel consumption, measured by filling the fuel tanks before and after each operation and recording the difference in volume. For the aircraft operations (pesticide application once and nutrient application six times) fuel consumption was provided by the service supplier; c) the electricity consumption for pumping water to the rice fields, measured as the difference registered in the electric meter at the start and the end of the cropping season; d) the time the water pump was running; e) the weight of all equipment, with the weight of tires and tubes separately considered.

Description of the machinery, their weight, operational yield, average fuel consumption, embodied energy and total energy consumption is presented in the item D, in the Supplementary Information section. Embodied energy is the energy consumed to build the machinery. Embodied energy of machinery and the energetic depreciation in time was calculated using procedures described by Bowers (1992) and Pimentel (1992). Additionally, the amount and type of seeds, nutrients and pesticides used were registered for each cropping system.

To estimate the energy consumption related to labour, the recorded time of field operations was used as a basis. Additionally, 30 minutes extra for seeding and harvesting, and 15 minutes extra for soil operations, pesticide application, spreading nutrients and seeds, to account for loading and cleaning the machinery after use were added. Also, 25 minutes and 1 $\mathrm{L}$ of diesel were added to each field operation, to cover for the round trips between the LES machinery shelter (garage) and the farming systems $(5.2 \mathrm{~km})$. The time for managing the cattle and the time for monitoring and maintenance of channels and levees in rice fields were also recorded.

A pumping station located in a lake at approximately $1.5 \mathrm{~km}$ from the experimental area supplied water for irrigation of rice fields. A centrifugal horizontal pump (430 kg), running with a 100-CV three-phase electric motor (486 kg) was used for pumping.

The experimental farms were located at $16 \mathrm{~km}$ from the commercial point of acquisition of supplies and delivery of grains and cattle. To assess the transporting costs, the weight of main inputs (fertilizers, diesel fuel, seeds and pesticides) and outputs (grains and cattle) were considered in these calculations. Distance from the farms to the market point was multiplied by 2 , to account for the return journeys. Data from a truck of $20,000 \mathrm{~kg}$ load capacity yielding 2.75 $\mathrm{km} \mathrm{L}^{-1}$ of diesel was used. The average time in transport of goods was 1.75 hours for acquiring inputs and 2.0 hours for delivering grains and cattle. 


\section{Energy content in inputs and outputs}

The energy equivalent contained in inputs, grains, biomass and livestock are described in the item E, in the Supplementary Information session. Due to difficulties in finding reliable regional data about the energy content of inputs, we applied the following criteria for obtaining reasonable information: a) using data earlier described for similar cropping system evaluations; b) using data that included production, packaging and distribution costs; c) using the most recent data available in literature.

\section{Carbon $(\mathrm{C})$ in soil, greenhouse gas emissions (GHG) and $\mathrm{CO}_{2}$-e balance (Global Warming}

\section{Potential)}

The accumulation of $\mathrm{C}$ in the soil $(0$ to $20 \mathrm{~cm})$ was calculated as the difference between the content of soil organic matter (SOM) at the start and the end of the experiment. The C in SOM was assumed as 58\% and was adjusted to soil bulk density, as described in Rosa et al. (2011). The value for carbon in plant residues was estimated to be $45 \%$ of the dry mass, following data for similar crops from Aita and Giacomini (2003) and Niu et al. (2016). GHG emissions ( $\mathrm{CH}_{4}$ and $\mathrm{N}_{2} \mathrm{O}$ ) were estimated in $\mathrm{CO}_{2}$-equivalent units $\left(\mathrm{CO}_{2}\right.$-e), using conversion indexes 25 and 298, for $\mathrm{CH}_{4}$ and $\mathrm{N}_{2} \mathrm{O}$, respectively, as proposed by IPCC (2006). The $\mathrm{CO}_{2}$-e balance (net Global Warming Potential) for each cropping system was assessed by calculating the difference between the $\mathrm{C}$ from emissions (converted from $\mathrm{CO}_{2}$-e) and the $\mathrm{C}$ sequestered as organic matter in the soil.

GHG emission values adopted for inputs were $3.368 \mathrm{~kg} \mathrm{CO}_{2}-\mathrm{e} \mathrm{L} \mathrm{L}^{-1}$ for diesel $(2.966 \mathrm{~kg}$ $\mathrm{CO}_{2}$-e from combustion (IPCC, 2006) $+0.320 \mathrm{~kg} \mathrm{CO}$-e from production (Carvalho, 2012) + $0.082 \mathrm{~kg} \mathrm{CO}_{2}$-e from transports (Eriksson \& Ahlgren, 2013)); $5.15 \mathrm{~kg} \mathrm{CO}_{2}$-e kg-1 for urea, 2.03 $\mathrm{kg} \mathrm{CO}_{2}$-e kg ${ }^{-1}$ for di-ammonium-phosphate, $0.27 \mathrm{~kg} \mathrm{CO}_{2}$-e $\mathrm{kg}^{-1}$ for super triple phosphate, 0.25 $\mathrm{kg} \mathrm{CO}_{2}-\mathrm{e} \mathrm{kg}^{-1}$ for potassium chloride (Fertilizers Europe, 2014). For pesticides, an emission of $0.069 \mathrm{~kg} \mathrm{CO}$-e per MJ required to produce $1 \mathrm{~kg}$ a.i. was assumed (Audsley et al., 2009). The GHGs emitted for seeding material (seed production, processing, packaging and transport) were estimated as a function of seed energy content (adapted from Heichel, 1980). Values used were $3.02 ; 0.97 ; 0.98 ; 1.09 ; 1.17 ; 1.06$ and $1.02 \mathrm{CO}_{2}$-e kg seed ${ }^{-1}$ for maize, rice, soybean, ryegrass, black oats, vetches and radish seeds, respectively. Emission of $\mathrm{CH}_{4}$ from enteric fermentation by cattle was calculated following Tier 2 from IPCC for the RS State $\left(45 \mathrm{~kg} \mathrm{CH}_{4}\right.$ head $^{-1}$ $\left.\mathrm{yr}^{-1}\right) ; \mathrm{N}_{2} \mathrm{O}$ released from manure excreted in pastures was assumed as $2 \%$ of the $\mathrm{N}$ content of manure (Lima et al., 2010). $\mathrm{CH}_{4}$ emissions from irrigated rice followed the regional standards of 0.395 
and $0.266 \mathrm{Mg} \mathrm{CH}_{4} \mathrm{ha}^{-1}$ season $^{-1}$ for conventional and minimum-tillage, respectively (Bayer et al., 2013). Emissions from crop and cover crop residues followed the assumption that 1\% of nitrogen in the residues are emitted as $\mathrm{N}_{2} \mathrm{O}$ (IPCC, 2006). Content of $\mathrm{N}$ in biomass was $2.43 \%$ for the leguminous and $1.25 \%$ for the non-leguminous species (Aita \& Giacomini, 2003; Assmann et al., 2015). GHG emissions associated with production and maintenance of machinery was assumed to be $5.38 \mathrm{~kg} \mathrm{CO}_{2}-\mathrm{e} \mathrm{kg}^{-1}$ for small tractors $(75 \mathrm{CV})$ and implements, $4.93 \mathrm{~kg} \mathrm{CO} 2-\mathrm{e} \mathrm{kg}^{-1}$ for medium-size tractors $(121 \mathrm{CV})$ and $4.94 \mathrm{~kg} \mathrm{CO} 2-\mathrm{e}$ $\mathrm{kg}^{-1}$ for harvesters (Mantoam et al., 2016).

\section{Data adjustment in Rice-Fallow cropping system}

The Rice-Fallow cropping system completed 1.5 full cycles in the timespan of this study. The missing part of the $2^{\text {nd }}$ cycle corresponds to the period in which the system would be on rice production. For some indicators, this imbalance would result in biased, incorrect results. To correct for this, we included additional seasons for this cropping system through simulation. The new data, simulating three additional cropping seasons, were estimated using the Bayesian Monte Carlo's method, in WinBugs software (Lunn et al., 2000). To generate the new set of data, initial yield predictions for 2016, 2017 and 2018 based on a squared-regression of the yearly rice yields from the 12 municipalities near LES between 2000 to 2015, were combined with the grain yield obtained in the experimental Rice-Fallow system registered in 2010, 2011 and 2012. For input data, the amount of inputs used in the previous rice growing period (20102012) was increased with $2 \%$, to follow the regional trend. Cattle and other biomass production used in the simulated period was the same as registered in 2010 to 2012 cropping seasons. All comparisons evolving from these adjusted data, or the indicators derived from it, were normalised on a yearly basis.

\section{Data summary and indicators established}

The first step of this analysis consisted of a check on the grain yields obtained in the experimental condition for rice, soybean and maize, as well as the respective regional averages (Item $\mathrm{F}$ in the Supplementary Information section). In the second step, we summarized the fraction of time the field in each cropping system was left fallow or occupied by grain crops, cover crops, pastures or cattle. Subsequently, the partitioning of biomass produced by the cropping systems was analysed. Newly produced biomass was separated in grains from cash crops, any other plant biomass and gains in cattle live weight. Hereafter, the yield of grains and cattle weight gains destined for human consumption will simply be termed as "food". Biomass 
production was further distinguished according to the season it was produced in, either summer or winter. The balance of main nutrients $\left(\mathrm{N}, \mathrm{P}_{2} \mathrm{O}_{5}\right.$ and $\left.\mathrm{K}_{2} \mathrm{O}\right)$ was calculated based on the difference between the nutrients applied and the nutrients exported as food. Nutrient cycling within the cropping systems by means of cattle manure were also calculated. For this, we used the guidelines from Comissão de Química e Fertilidade do Solo - RS/SC (2004).

For each cropping system, the total energy consumed (TEC) was calculated. For the TEC, a distinction was made between direct and indirect energy sources. Direct energy sources include production-related energy expended on-farm: fuels, electricity, seeds and human labour; indirect energy sources is the production related off-farm energy use, including energy costs of producing fertilizers, pesticides and energy embodied in the machinery (Campos \& Campos, 2004).

$$
\text { TEC }\left(\mathrm{MJ} \mathrm{ha}{ }^{-1}\right)=\Sigma \text { inputs (direct energy }+ \text { indirect energy) }
$$

The energy balance (EB) was calculated by subtracting the total energy consumed (TEC) from the energy contained in both grains and gains in cattle live weight (EnFood).

$$
\mathrm{EB}\left(\mathrm{MJ} \mathrm{ha}^{-1}\right)=\text { EnFood }- \text { TEC }
$$

The net energy ratio (NER), also called Energy Return on Energy Investment, represents the energetic conversion of a production system. Net energy ratios for the cropping systems were calculated according to the formula below.

$$
\operatorname{NER}\left(\mathrm{MJ} \mathrm{ha}^{-1}\right)=\frac{\text { EnFood }}{\text { TEC }}
$$

The capacity of cropping systems to convert natural resources, particularly water and solar radiation, in grains, was assessed by means of the productivity indicators Water Productivity (WP) (Kijne et al., 2003) and Solar Radiation Productivity (SRP). The resource availability of both indicators was calculated based on the daily weather records (presented in the item $\mathrm{C}$ in the Supplementary Information session). WP and SRP were estimated at three integration levels: for individual crops; for all grain crops within a cropping system; and for the overall cropping system. The period considered for determining the available water for calculation of WP started five days before crop seeding and finished at the date of harvest. WP included rains and water used in rice irrigation. The SRP is a modified version of the Radiation Use Efficiency indicator (Campillo et al., 2012). In the SRP, rather than using the intercepted radiation, the incident photosynthetically active radiation (PAR) is considered. The start date 
for SRP was at crop emergence, and the final date was at crop maturity, which corresponded to one week after the R9 growth stage for rice, growth stage R8 for soybean and growth stage R6 for maize. PAR was estimated as $47 \%$ of the total solar incident radiation (Assis \& Mendez, 1989). To calculate the SRP of the whole system, all biomass produced by a cropping system was considered, not just the grains. The following formulas were used:

$$
\begin{aligned}
& \mathrm{WP}\left(\mathrm{kg} \mathrm{mm}^{-1}\right)=\frac{\text { grains }\left(\mathrm{kg} \mathrm{ha}^{-1}\right)}{\text { rainwater+irrigation }\left(\mathrm{mm} \mathrm{ha}^{-1}\right)} \\
& \mathrm{SRP}\left(\mathrm{kg} \mathrm{GJ} \mathrm{PAR}^{-1}\right)=\frac{\text { grains (or biomass) }\left(\mathrm{kg} \mathrm{ha}^{-1}\right)}{\text { PAR }\left(\mathrm{GJ} \mathrm{ha} \mathrm{h}^{-1}\right)}
\end{aligned}
$$

The capability of cropping systems to deliver a social benefit (number of people fed per unit of area cultivated per year (PFY)) was estimated. To calculate PFY, the energy and the protein harvested as food were divided by the consumption of an average person. Average daily human consumption was set to $80 \mathrm{~g} \mathrm{~d}^{-1}$ and $8.7 \mathrm{MJ} \mathrm{d}^{-1}$ for protein and energy, respectively. The protein levels used to calculate PFY were $9 \%$ for maize, $7 \%$ for rice husked grains $(65 \%$ milling yield), $36 \%$ for soybean and $64 \%$ for the cattle meat on dry mass basis. The energetic content of rice, maize, soybean and meat is listed in the item E, in the Supplementary Information section.

Two sets of carbon-based footprints were calculated for each cropping system. The first set was based on the average annual amount of GHG emissions, whereas the second set was based on the soil-atmosphere $\mathrm{CO}_{2}$-e balance. Both values were divided by the food produced in a system, resulting in the "GHG Intensity Footprint" and the " $\mathrm{CO}_{2}$-e Footprint". Alternatively, both values ( $\mathrm{GHG}$ emissions and $\mathrm{CO}_{2}$-e balance) were divided by the number of persons fed per year (PFY) on energy basis, resulting in the "Personal GHG Footprint" and the "Personal $\mathrm{CO}_{2}$-e Footprint" indicators.

\section{Statistical analysis}

Each crop system was conducted in a unique large plot, and the analysis performed with data collected during nine cropping seasons. Data were tested for normality assumption by using the Shapiro-Wilk test, provided by the Proc Univariate in SAS software version 9.3 (SAS Institute, 2016). Descriptive statistics (means, medians, standard error of means (SEM) and standard deviation (SD)) were obtained in SAS, using the Proc Means procedure. Mixed models, with cropping systems as the fixed factor and cropping seasons as random factors, were 
applied to data using Proc Mixed in SAS. The cropping systems were compared by the differences of least squares means (LSMeans), using a critical level of $p=0.05$. The carbonbased footprint indicators presented non-normal data distribution and were reported with medians and SD, instead of means and SEM. Extreme values in some cropping seasons skewed the means far from the realistic values, and this could easily result in an incorrect interpretation of results. Medians were more robust descriptors of data in this case. Indicators and variables are presented as annual means and their corresponding SEM, except if indicated otherwise.

\subsection{Results}

\section{Grain yields}

In the study period (2007-2015), the average grain yield of rice, soybean and maize for the 14 municipalities near the experimental area were 7.4 (rice), 2.2 (soybean) and 2.7 (maize) $\mathrm{Mg} \mathrm{ha}^{-}$ ${ }^{1}$ (IBGE, 2016). Under the experimental conditions, the average grain yield of rice and soybean obtained in the three rice-based cropping systems were similar to these regional averages. In contrast, in both ridge-based cropping systems, the average grain yields of soybean and maize were superior over the regional yields. For soybean, the average yield was about $15 \%$ higher. For maize, a much more substantial difference was observed, as average grain yield in these new systems was around $140 \%$ higher than the regional average. It shows that particularly maize benefitted from the conditions provided by the ridge-based systems.

\section{Distribution of activities over time}

Cash crops (rice, soybean and maize) were only cultivated in summer. In the Rice-Fallow system, the land was used for grain production during $20 \%$ of the time, whereas in the remaining $60 \%$ land was kept fallow. Cattle was kept for about $20 \%$ of the time (Figure 2). In the other cropping systems, the use of land for cash crops more or less doubled, to around $40 \%$ of the time. In the rice-soybean systems the land was on fallow for approximately $60 \%$ of time, period that corresponds to winter, when fields are unused.

Contrarily to the other production models, the ridge-based systems did not include a fallow. The dry soil provided by the ridges permitted the cultivation of pastures (in Ridges and Cattle) and cover crops (in Ridges and Cover crops) during winter. Cattle were kept in the field for a small portion of time in the ridge-based systems ( $22 \%$ of wintertime for Ridges and Cattle, and $8 \%$ of wintertime for Ridges and Cover crops). 


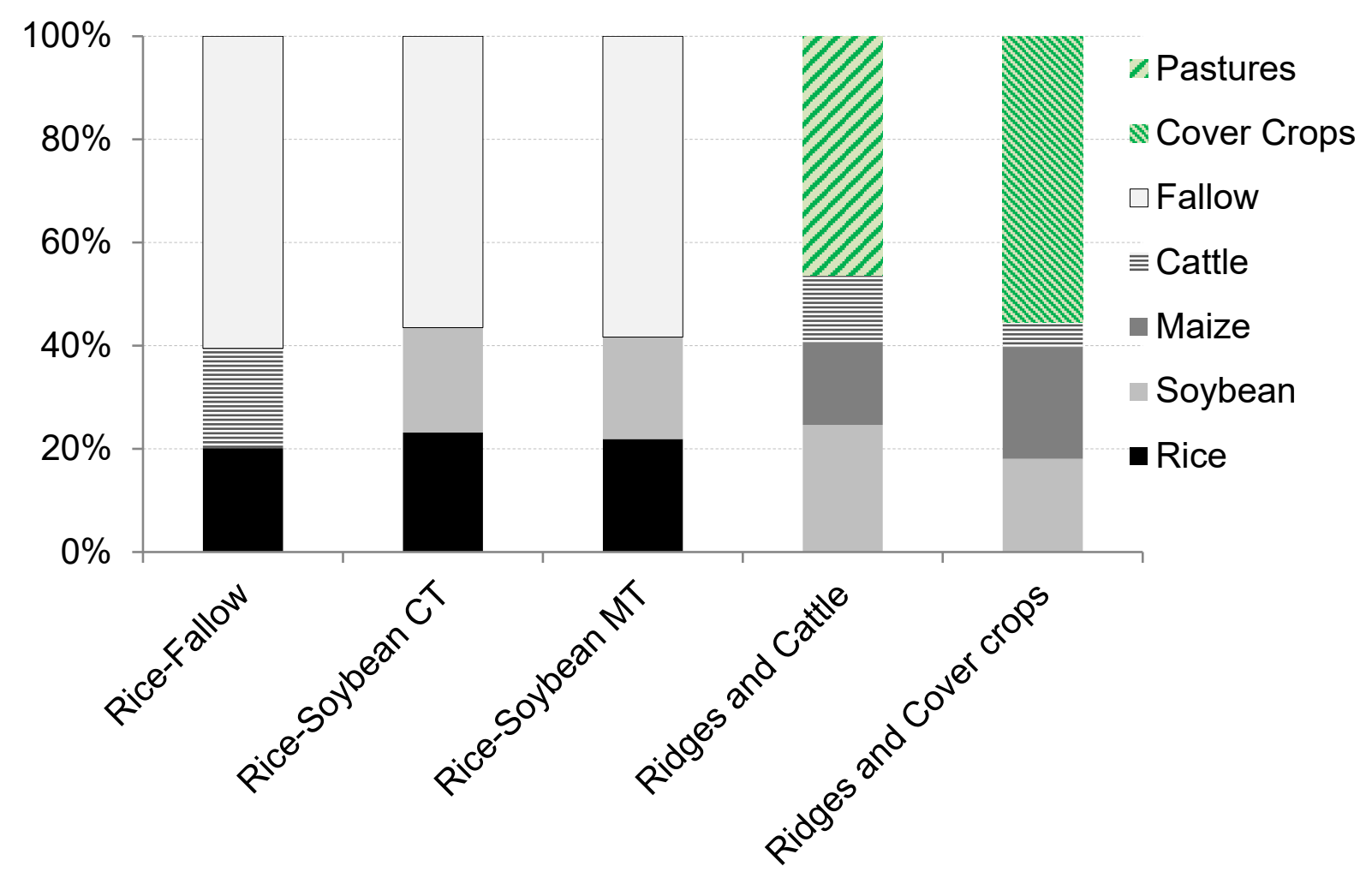

Figure 2. Cumulative fraction of time fields were occupied with a main crop (rice, soybean or rice), cattle, pastures, cover crops, or were left fallow in five cropping systems.

\section{Biomass production}

Biomass production patterns differed between the cropping systems $(p<0.05)$. In the RiceFallow, grains (rice) corresponded to $44 \%$ of the total biomass produced by this cropping system. In both rice-soybean systems, the biomass from grains made up the larger part (53\%) of the total biomass produced. But this fraction was only $33 \%$ for the ridge-based systems (Table 1). While the production of grains in the rice-soybean systems was $5.07 \mathrm{Mg} \mathrm{ha}^{-1}$ per year, the crops cultivated in the ridge-based systems produced around $9 \%$ less. However, in the ridge-based systems the biomass remaining in the soil was two times larger than in the ricesoybean systems. In cropping systems producing cattle, the gains in livestock weight made up only a very small amount of the total biomass production. The total biomass produced in the ridge-based systems was on average $13.5 \mathrm{Mg} \mathrm{ha}^{-1} \mathrm{yr}^{-1}$, which was significantly larger than the biomass produced by the Rice-Fallow system. The difference between these systems was approximately $5.2 \mathrm{Mg} \mathrm{ha}^{-1} \mathrm{yr}^{-1}$.

No differences in residue biomass of the summer crops were observed between the five cropping systems. On average, an estimated 3.96 $\mathrm{Mg} \mathrm{DM} \mathrm{ha}^{-1}$ per year was produced in 
summer (Figure 3). Clearly, the large differences in biomass production between cropping systems occurred in winter: that of the ridge-based systems being 12 to 33 times higher than in rice-soybean systems and 4.5 to 5.5 times higher than the Rice-Fallow system.

Table 1. Average annual production of biomass and the partition of this biomass over grains, cattle and other biomasses in five cropping systems

\begin{tabular}{lccccc}
\hline & \multicolumn{5}{c}{ Cropping system } \\
\cline { 2 - 6 } Product & Rice-Fallow & $\begin{array}{c}\text { Rice-Soybean } \\
\text { CT }\end{array}$ & $\begin{array}{c}\text { Rice-Soybean } \\
\text { MT }\end{array}$ & $\begin{array}{c}\text { Ridges and } \\
\text { Cattle }\end{array}$ & $\begin{array}{c}\text { Ridges and Cover } \\
\text { crops }\end{array}$ \\
\cline { 2 - 6 } & \multicolumn{5}{c}{$\mathrm{kg} \mathrm{ha}^{-1} \mathrm{yr}^{-1}$} \\
\hline Grains & $3652(265)$ & $5196(992)$ & $4943(871)$ & $4896(990)$ & $4159(630)$ \\
Cattle & $50(14)$ & - & - & $152(23)$ & $42(5)$ \\
$\begin{array}{l}\text { Other } \\
\text { biomasses }\end{array}$ & $4617(537)$ & $4492(719)$ & $4523(615)$ & $8713(927)$ & $9093(994)$ \\
\hline Total & $8319(1595) \mathrm{b}$ & $9688(1711) \mathrm{ab}$ & $9466(1483) \mathrm{ab}$ & $13761(1764) \mathrm{a}$ & $13294(1477) \mathrm{a}$ \\
\hline
\end{tabular}

The mass of grains is adjusted to $13 \%$ of moisture, the mass of cattle as gains in live weight and the other biomasses as dry mass. Means followed by the same letter are not significantly different at $p<$ 0.05. Values between parentheses are the SEM.

\section{Carbon in soil, GHG emissions and carbon balance}

In 2006, the amount of carbon in the soil (0 to $20 \mathrm{~cm}$ deep) was approximately $27 \mathrm{Mg} \mathrm{ha}^{-1}$. At the end of experiment (2015), the content varied between 27 and $34 \mathrm{Mg} \mathrm{ha}^{-1}$ (Table 2). Except for the Rice-Fallow system, all cropping systems sequestered carbon into the soil, with values ranging from 0.13 to $0.77 \mathrm{Mg} \mathrm{C}$ ha $^{-1}$ per year. The rice-soybean cropping systems accumulated less $\mathrm{C}$ (around $0.5 \mathrm{Mg} \mathrm{ha}^{-1} \mathrm{yr}^{-1}$ less, on average) than the ridge-based systems.

The emissions of GHG varied between 2.2 and 7.2 $\mathrm{Mg} \mathrm{ha}^{-1} \mathrm{yr}^{-1}$ for the five cropping systems (Table 2). On average, the rice-soybean rotations emitted more GHG than the ridgebased systems. Rice-soybean conducted in conventional tillage emitted 30\% more $\mathrm{CO}_{2}$-e than in minimum tillage. This difference, however, was not statistically significant $(p=0.53)$. Cropping systems containing irrigated rice emitted, on average, $3.5 \mathrm{Mg} \mathrm{ha}^{-1} \mathrm{yr}^{-1}$ more than the systems without rice (ridge-based). The emission of methane from the flooded fields caused this difference. Methane represented approximately $70 \%$ of all GHG emissions in the three cropping systems containing irrigated rice (data not shown). 


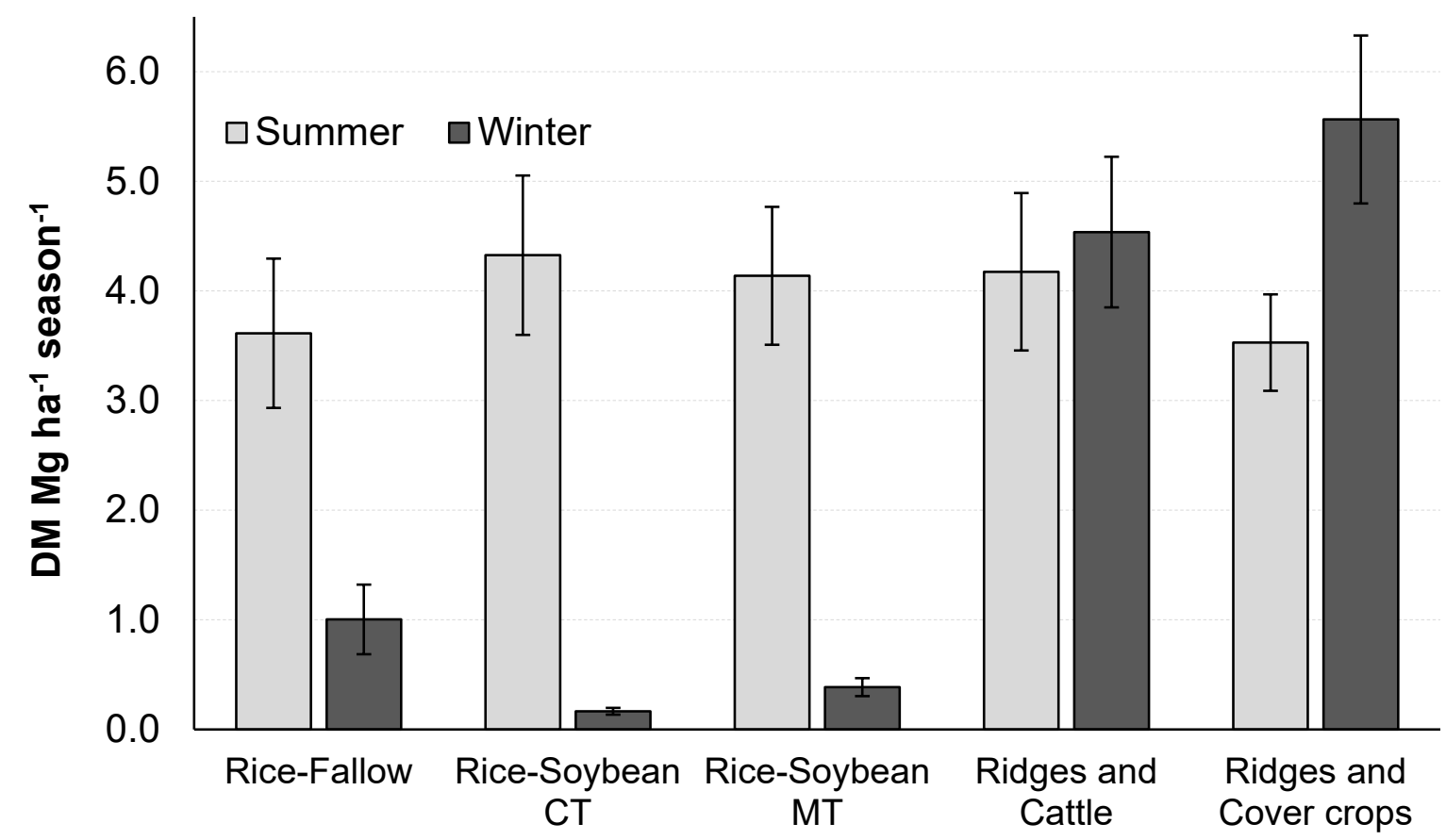

Figure 3. Biomass production ( $\mathrm{Mg} \mathrm{DM} \mathrm{ha}{ }^{-1}$ per season) in summer and winter in five cropping systems. Includes aerial biomass, roots and seeds. Grains from cash crops and gains in cattle live weight are not included. Error bars are the SEM.

Table 2. Organic carbon in soil $(0-20 \mathrm{~cm})$, carbon sequestered in organic matter, $\mathrm{CO}_{2}$-e emitted and balance of $\mathrm{CO}_{2}$-e between 2006 and 2015 in five cropping systems

\begin{tabular}{|c|c|c|c|c|c|}
\hline \multirow[b]{3}{*}{ Carbon in soil } & \multicolumn{5}{|c|}{ Cropping system } \\
\hline & Rice-Fallow & $\begin{array}{l}\text { Rice-Soybean } \\
\text { CT }\end{array}$ & $\begin{array}{c}\text { Rice-Soybean } \\
\text { MT }\end{array}$ & $\begin{array}{l}\text { Ridges and } \\
\text { Cattle }\end{array}$ & $\begin{array}{l}\text { Ridges and } \\
\text { Cover crops }\end{array}$ \\
\hline & \multicolumn{5}{|c|}{$\mathrm{Mg} \mathrm{C} \mathrm{ha}^{-1}$ in soil } \\
\hline C content (2006) & 27.77 & 26.43 & 26.43 & 27.36 & 27.36 \\
\hline C content (2015) & 27.92 & 27.59 & 28.61 & 34.33 & 33.16 \\
\hline $\mathrm{C}$ sequest. $\left(\mathrm{yr}^{-1}\right)$ & 0.016 & 0.129 & 0.243 & 0.774 & 0.645 \\
\hline $\begin{array}{l}\text { Emissions and } \\
\text { balance }^{\mathrm{a}}\end{array}$ & \multicolumn{5}{|c|}{$\mathrm{MgCO}_{2}-\mathrm{e} \mathrm{ha}^{-1} \mathrm{yr}^{-1}$} \\
\hline $\mathrm{CO}_{2}$-e emitted & $5.03(1.32) \mathrm{ab}$ & $7.12(2.02) \mathrm{a}$ & $5.56(1.46) \mathrm{a}$ & $2.64(0.30) b c$ & $2.23(0.19) \mathrm{c}$ \\
\hline $\mathrm{CO}_{2}$-e balance & $-4.97(1.32) \mathrm{b}$ & $-6.65(2.02) b$ & $-4.67(1.46) b$ & $0.19(0.30) \mathrm{a}$ & $0.13(0.19) \mathrm{a}$ \\
\hline
\end{tabular}

The Rice-Fallow system, even though it left the level of SOM unchanged, presented a negative $\mathrm{CO}_{2}$-e balance and had a negative profile in terms of global warming potential. 
Negative $\mathrm{CO}_{2}$-e balances also occurred in both rice-soybean cropping systems. The amount of biomass produced and sequestered into the soil was not sufficient to guarantee a net accumulation of $\mathrm{C}$ in these systems. On the other hand, the cropping systems conducted on ridges had a net accumulation of carbon into the soil, estimated to be equivalent to $0.16 \mathrm{Mg}$ $\mathrm{CO}_{2}$-e per ha per year, averaged over both systems (Table 3). The carbon from biomass effectively sequestered into the soil organic matter varied between cropping systems, being calculated as less than $1 \%$ for the Rice-Fallow system, $6 \%$ for Rice-Soybean CT, $12 \%$ for RiceSoybean MT, and between 16 and 20\% for the ridge-based systems.

\section{Soil characteristics and nutrient balance}

The level of soil organic matter was around $1.6 \%$ in 2006, but varied between $1.7 \%$ and $2.3 \%$ in 2015 (Figure 4). The changes in SOM were small in the systems containing rice, but increased $46 \%$ in the cropping systems conducted on ridges.

Between 2006 and 2015, soil K and P levels declined in the Rice-Fallow, while P increased in all other systems. In the ridge-based cropping systems, the levels of $\mathrm{P}$ increased between 10 (Ridges and Cover crops) and 36 (Ridges and Cattle) times. In the cropping systems with crop rotation and minimum- or no-tillage Rice-Soybean MT, Ridges and Cattle, and Ridges and Cover crops, the level of $\mathrm{K}$ was increased (Figure 4).

The amount of $\mathrm{N}, \mathrm{P}_{2} \mathrm{O}_{5}$ and $\mathrm{K}_{2} \mathrm{O}$ applied as fertilizer in the cropping systems followed the official recommendations for soil nutrition in south Brazil for medium to high grain yields of the respective crops (Comissão de Química e Fertilidade do Solo - RS/SC, 2004), and thus received distinct average annual amounts of nutrients. The ridge-based systems received more nutrients through fertilizers than the other cropping systems (Table 3). Use of fertilizers during winter was the main reason for this difference. Around $25 \%$ of fertilizers in the ridge-based systems were applied during winter, on pastures or cover crops. In most cropping systems, $\mathrm{K}_{2} \mathrm{O}$ was the nutrient applied in the highest quantity. However, for the Rice-Fallow system, which did not have leguminous crops included, $\mathrm{N}$ was the nutrient applied in the highest quantity. 

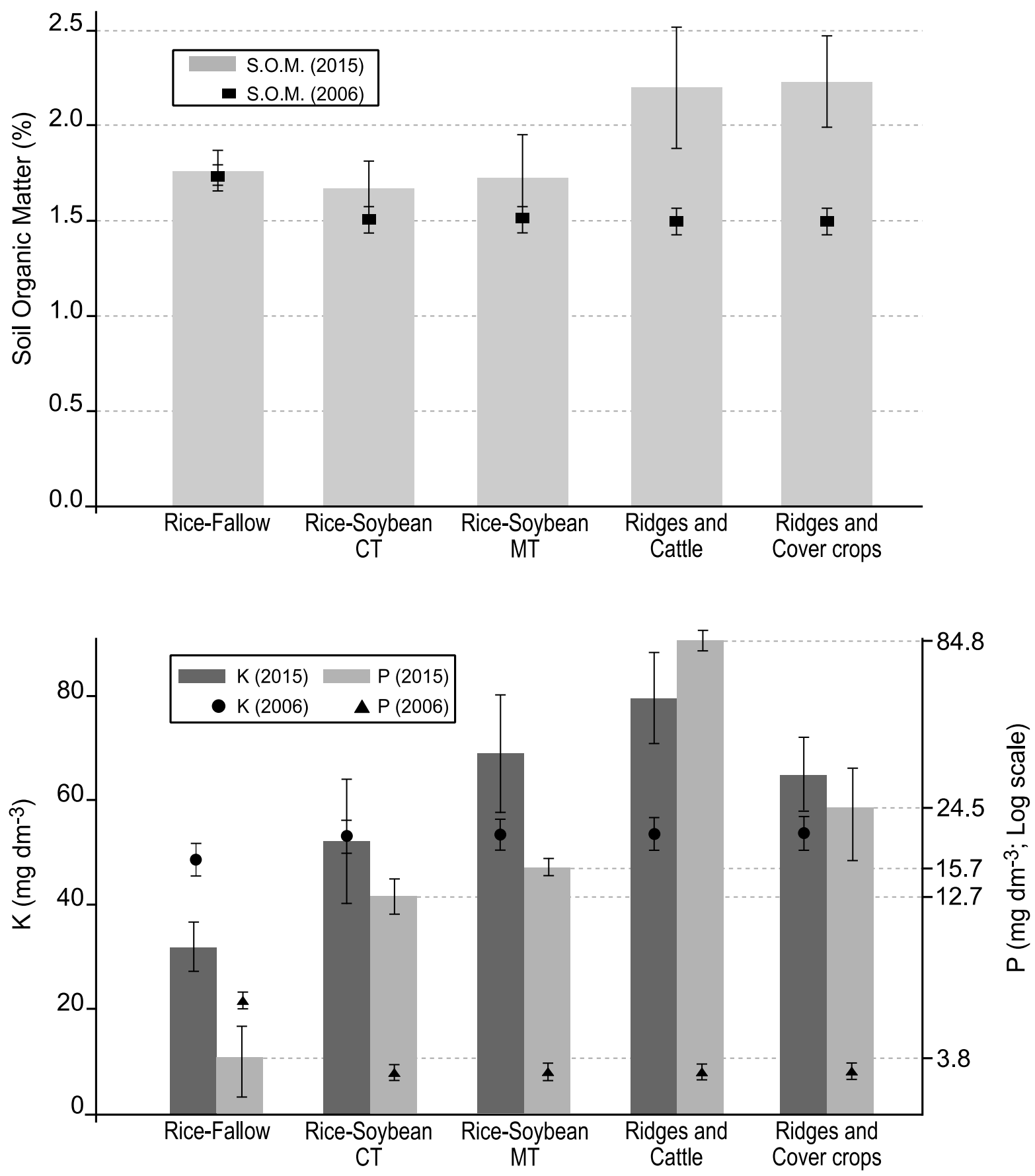

Figure 4. Level of Soil Organic Matter (S.O.M.), K and P in 0 to $10 \mathrm{~cm}$ soil profile in five cropping systems in 2006 and after nine years of rotation. Error bars are the SEM.

On average, the yearly exports of food from the cropping systems contained $95 \mathrm{~kg} \mathrm{~N} \mathrm{ha}{ }^{-}$ $1,39 \mathrm{~kg} \mathrm{P}_{2} \mathrm{O}_{5} \mathrm{ha}^{-1}$ and $38 \mathrm{~kg} \mathrm{~K}_{2} \mathrm{O} \mathrm{ha}^{-1}$ (Table 3). For all systems, the simplified balance between applied and exported nutrients was positive: more nutrients were applied than removed from the fields. The ridge-based systems accumulated around $150 \mathrm{~kg} \mathrm{ha}^{-1} \mathrm{yr}^{-1}$ of nutrients $\left(\mathrm{N}+\mathrm{P}_{2} \mathrm{O}_{5}\right.$ 
$+\mathrm{K}_{2} \mathrm{O}$ ), rice-soybean systems accumulated $97 \mathrm{~kg} \mathrm{ha}^{-1} \mathrm{yr}^{-1}$ and the Rice-Fallow system around $39 \mathrm{~kg} \mathrm{ha}^{-1} \mathrm{yr}^{-1}$.

Table 3. Nutrients applied, exported through grains and cattle and nutrient balance in five cropping systems

\begin{tabular}{lccccc}
\hline \multirow{2}{*}{ Nutrient } & \multicolumn{5}{c}{ Cropping systems } \\
\cline { 2 - 6 } & $\begin{array}{c}\text { Rice- } \\
\text { Fallow }\end{array}$ & $\begin{array}{c}\text { Rice- } \\
\text { Soybean CT }\end{array}$ & $\begin{array}{c}\text { Rice- } \\
\text { Soybean MT }\end{array}$ & $\begin{array}{c}\text { Ridges and } \\
\text { Cattle }\end{array}$ & $\begin{array}{c}\text { Ridges and } \\
\text { Cover crops }\end{array}$ \\
\cline { 2 - 6 } & \multicolumn{5}{c}{ Nutrients applied $\left(\mathrm{kg} \mathrm{ha}^{-1} \mathrm{yr}^{-1}\right)$} \\
\hline $\mathrm{N}$ & 48.6 & 67.2 & 67.2 & 86.2 & 87.0 \\
$\mathrm{P}_{2} \mathrm{O}_{5}$ & 38.3 & 77.0 & 77.0 & 77.7 & 86.8 \\
$\mathrm{~K}_{2} \mathrm{O}$ & 37.4 & 83.7 & 83.7 & 105.9 & 97.8 \\
\hline Total & 124.3 & 227.9 & 227.9 & 269.8 & 271.5 \\
\hline
\end{tabular}

Nutrients exported through grains and cattle $\left(\mathrm{kg} \mathrm{ha}^{-1} \mathrm{yr}^{-1}\right)$

\begin{tabular}{lccccc}
\hline $\mathrm{N}$ & 41.2 & 94.4 & 94.8 & 135.0 & 109.5 \\
$\mathrm{P}_{2} \mathrm{O}_{5}$ & 25.9 & 39.2 & 37.6 & 50.0 & 41.9 \\
$\mathrm{~K}_{2} \mathrm{O}$ & 18.4 & 40.0 & 39.9 & 49.8 & 40.6 \\
\hline Total & 85.5 & 173.6 & 172.3 & 234.9 & 192.0 \\
\hline
\end{tabular}

Nutrient balance $\left(\mathrm{kg} \mathrm{ha}^{-1} \mathrm{yr}^{-1}\right)$

\begin{tabular}{lccccc}
\hline $\mathrm{N}$ & 7.4 & $13.1^{*}$ & $16.2^{*}$ & $53.0^{*}$ & $60.2^{*}$ \\
$\mathrm{P}_{2} \mathrm{O}_{5}$ & 12.4 & 37.8 & 39.3 & 27.7 & 44.9 \\
$\mathrm{~K}_{2} \mathrm{O}$ & 19.0 & 43.7 & 43.8 & 56.0 & 59.3 \\
\hline & 38.8 & 94.7 & 99.4 & 136.7 & 162.3
\end{tabular}

* The balance was adjusted assuming that $\mathrm{N}$ for soybean was supplied by symbiosis with Bradyrhizobium, at efficiency rates of $85 \%$ in rice-soybean systems and $95 \%$ in ridge-based systems.

\section{Manure production and nutrient cycling within the cropping systems}

The integration of irrigated rice with beef-cattle is used in large parts of the lowlands in the RS state. The nutrients contained in manure, cycled from cattle into the soil, corresponded to $52 \%$, $44 \%$ and $9 \%$ of all external nutrients applied into the Rice-Fallow, Ridges and Cattle and Ridges and Cover crops systems, respectively (Table 4). For the Rice-Fallow, the manure probably was the most important source of nutrients available to plants in winter, besides some residual nutrients from the previous rice cultivation. Manure is a known source of nutrients, supports soil microbial live and can affect the nutrient balance in the soil, but a detailed evaluation of how manure decomposition affected soil fertility was not an objective of the present study. 
Table 4. Manure produced and respective amount of nutrients cycled into the five cropping systems

\begin{tabular}{|c|c|c|c|c|c|}
\hline \multirow{3}{*}{ Component } & \multicolumn{5}{|c|}{ Cropping Systems } \\
\hline & $\begin{array}{l}\text { Rice- } \\
\text { Fallow }\end{array}$ & $\begin{array}{c}\text { Rice-Soybean } \\
\text { CT }\end{array}$ & $\begin{array}{c}\text { Rice-Soybean } \\
\text { MT }\end{array}$ & $\begin{array}{l}\text { Ridges and } \\
\text { Cattle }\end{array}$ & $\begin{array}{l}\text { Ridges and } \\
\text { Cover crops }\end{array}$ \\
\hline & \multicolumn{5}{|c|}{$\mathrm{kg} \mathrm{ha}^{-1} \mathrm{yr}^{-1}$} \\
\hline Dung + urine & 1478 & 0 & 0 & 2729 & 525 \\
\hline $\mathrm{N}$ & 22.2 & 0 & 0 & 40.9 & 7.9 \\
\hline $\mathrm{P}_{2} \mathrm{O}_{5}$ & 20.7 & 0 & 0 & 38.2 & 7.5 \\
\hline $\mathrm{K}_{2} \mathrm{O}$ & 22.2 & 0 & 0 & 40.9 & 7.9 \\
\hline Total nutrients & 65.1 & 0 & 0 & 120.0 & 23.3 \\
\hline
\end{tabular}

\section{Energy consumption, balance and conversion}

Of all systems evaluated, the Rice-Fallow consumed the smallest amount of energy (Figure 5). This is not surprising, since rice cultivation, the most energy-demanding activity, was present in the field for a relatively short period of time. Fallow and cattle production demand a low amount of energy compared to rice production. The rice-soybean cropping systems required, on average, $45 \%$ more energy than the Rice-Fallow system. The ridge-based systems, in turn, required on average $30 \%$ more energy than the Rice-Fallow but $11 \%$ less energy than the ricesoybean systems.

In the systems containing irrigated rice, the proportion of direct energy was apparently higher than in the other systems. Energy for irrigation makes the difference in this case (data not shown). For the ridge-based cropping systems, direct and indirect energy were roughly consumed in similar amounts. The overall values of energy consumed in the cropping systems [15 to $22 \mathrm{GJ} \mathrm{ha}^{-1} \mathrm{yr}^{-1}$ ] are within the range previously reported for studies on energy use in diversified cropping systems (Alipour et al., 2012; Fuksa et al., 2013; Sá et al., 2013). 


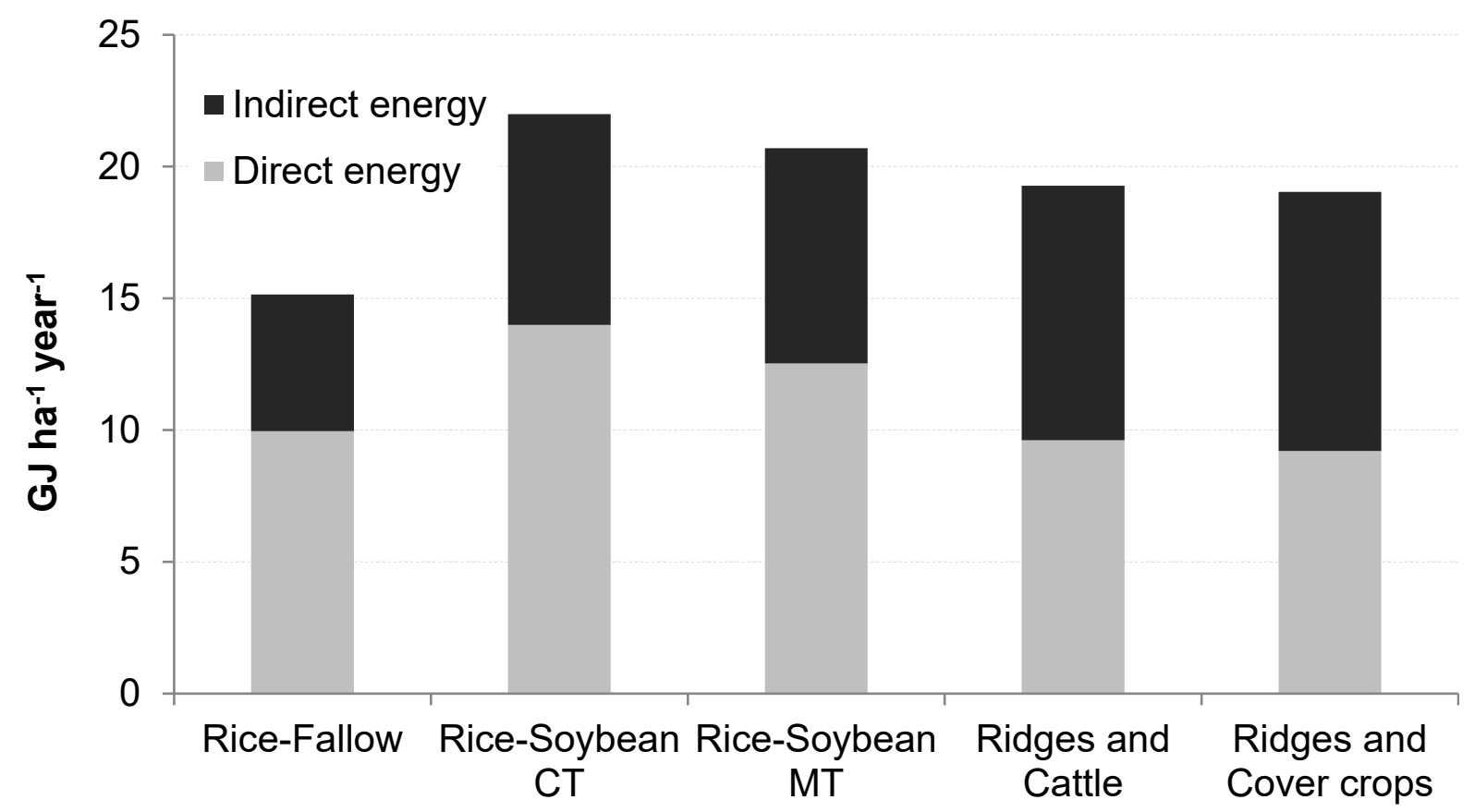

Figure 5. Average annual energy consumption (TEC), distinguished according to source type (direct or indirect), by five cropping systems.

All cropping systems had a positive energy balance: the energy produced as food was higher than the energy supplied to produce it. The net energy balance varied between 44 and $63 \mathrm{GJ} \mathrm{ha}^{-1}$ year $^{-1}$ and did not differ significantly between cropping systems $(p=0.72)$. The net energy ratio (NER) however did differ between cropping systems, being, on average, $56 \%$ and $9 \%$ higher in the ridge-based systems than in the rice-fallow and rice-soybean systems, respectively (Table 5).

Table 5. Energy balance (energy out - energy in, GJ ha ${ }^{-1}$ year $^{-1}$ ) and net energy ratio (energy out : energy in) of the five cropping systems

\begin{tabular}{lccccc}
\hline & \multicolumn{5}{c}{ Cropping systems } \\
\cline { 2 - 6 } Indicator & Rice-Fallow & $\begin{array}{c}\text { Rice-Soybean } \\
\text { CT }\end{array}$ & $\begin{array}{c}\text { Rice-Soybean } \\
\text { MT }\end{array}$ & $\begin{array}{c}\text { Ridges and } \\
\text { Cattle }\end{array}$ & $\begin{array}{c}\text { Ridges and } \\
\text { Cover crops }\end{array}$ \\
\hline $\begin{array}{l}\text { Energy Balance } \\
\left(\mathrm{GJ} \mathrm{ha}^{-1} \text { year }^{-1}\right)^{\mathrm{a}}\end{array}$ & $43.75(13.7)$ & $61.79(13.2)$ & $59.07(11.4)$ & $62.86(15.6)$ & $49.89(9.7)$ \\
\hline $\begin{array}{l}\text { Net Energy Ratio } \\
\left(\mathrm{MJ}_{\text {out }} \mathrm{MJ}_{\text {in }}{ }^{-1}\right)^{\mathrm{b}}\end{array}$ & $2.53(0.54) \mathrm{b}$ & $3.56(0.36) \mathrm{ab}$ & $3.68(0.31) \mathrm{ab}$ & $4.18(0.74) \mathrm{a}$ & $3.72(0.56) \mathrm{ab}$ \\
\hline
\end{tabular}

a. The means did not differ between the cropping systems $(p=0.72)$.

b. Means followed by the same letter are not significantly different at $p<0.05$.

Values between parentheses are the SEM. 


\section{Water Productivity}

Water Productivity from individual crops varied between 4.4 and $18.0 \mathrm{~kg} \mathrm{~mm}^{-1}$ (Table 6). Maize was the most efficient crop: it produced almost three times more grain weight per unit of water than soybean or rice. On average, the crops in the ridge-based systems were 2.3 times more efficient in using water than in the other cropping systems. When analysing water productivity at the cropping systems level, which included the rains occurred during winter and summer, a significant difference $(p<0.05)$ was found between the rice-fallow system and the novel ridgebased systems. On average, production of grains per unit of water in the ridge-based systems was around 3.7 times more efficient than in rice-fallow. These differences are partly inherent to the distinct crops used in these systems, but also due to the large time rice-fallow remains not cultivated. Obviously, water from rains during the fallow period is mostly 'wasted' and hardly used for grain production.

Table 6. Water Productivity of grain production $\left(\mathrm{kg} \mathrm{mm}^{-1}\right)$ in five cropping systems

\begin{tabular}{|c|c|c|c|c|c|c|}
\hline \multirow{3}{*}{ Crop } & \multicolumn{5}{|c|}{ Cropping systems } & \multirow{3}{*}{ Average $^{1}$} \\
\hline & Rice-Fallow & $\begin{array}{c}\text { Rice-Soybean } \\
\text { CT }\end{array}$ & $\begin{array}{c}\text { Rice-Soybean } \\
\text { MT } \\
\end{array}$ & $\begin{array}{c}\text { Ridges and } \\
\text { Cattle }\end{array}$ & $\begin{array}{l}\text { Ridges and } \\
\text { Cover crops }\end{array}$ & \\
\hline & \multicolumn{5}{|c|}{$\mathrm{kg} \mathrm{mm}^{-1}$} & \\
\hline Rice & $5.07(0.35)$ & $5.67(0.30)$ & $5.26(0.35)$ & - & - & $5.32(0.19)$ \\
\hline Maize & - & - & - & $18.04(1.19)$ & $12.58(2.49)$ & $15.49(1.63)$ \\
\hline Soybean & - & $4.44(0.24)$ & $5.28(0.85)$ & $4.72(0.62)$ & $4.63(0.20)$ & $4.77(0.27)$ \\
\hline $\begin{array}{l}\text { Crops } \\
\text { average }^{\mathrm{a}}\end{array}$ & $5.07(0.35) b$ & $5.44(0.26) \mathrm{b}$ & $5.26(0.32) b$ & $14.17(2.23) \mathrm{a}$ & $10.46(1.96) \mathrm{a}$ & - \\
\hline $\begin{array}{l}\text { System } \\
\text { average } \\
\end{array}$ & $1.30(0.45) b$ & $2.55(0.63) \mathrm{ab}$ & $2.57(0.65) a b$ & $5.33(1.70) \mathrm{a}$ & $4.29(1.34) \mathrm{a}$ & - \\
\hline \multicolumn{7}{|c|}{$\begin{array}{l}\text { a. Means weighted averaged by the amount of grains produced by each crop in the respective cropping } \\
\text { system; means followed by the same letter are not significantly different at } p<0.05 \text {. } \\
\text { b. Yearly average estimated from the grains produced and the water from rains and irrigation, during } \\
\text { the full time span of the experiment; means followed by the same letter are not significantly different } \\
\text { at } p<0.05 \text {. Values between parentheses are the SEM. }\end{array}$} \\
\hline
\end{tabular}

\section{Solar Radiation Productivity}

Values estimated for SRP of individual crops varied from 0.17 to $0.81 \mathrm{~kg}$ (GJ PAR)-1 (Table 7). Maize and rice were approximately 3.5 times more efficient than soybean. For maize, this result probably arises from a combination of the $\mathrm{C} 4$ photosynthetic pathway and the short growing cycle. For irrigated rice, the result occurred from a combination of a short growing cycle (110 days from emergence to maturation, on average) with the high grain yield produced under irrigation. Irrigation, in this case, seems to be the key factor to compensate the less efficient C3 photosynthetic pathway. 
When all biomass produced over the entire year was considered, the systems conducted on ridges had higher SRP values than the rice-and-fallow system $(p<0.05)$. Such difference can be attributed from the higher biomass produced during winter (Figure 3), as SRP's of grain crops (produced during summer) did not differ significantly between systems. The SRP in summer was similar between the cropping systems (average of $0.69 \mathrm{~kg}$ (GJ PAR) ${ }^{-1}$ ). For the winter, cropping systems running on ridges presented SRP of $0.46 \mathrm{~kg}$ (GJ PAR) ${ }^{-1}$, but only 0.06 $\mathrm{kg}(\mathrm{GJ} P A R)^{-1}$ was calculated for the systems running in flat soil (data not shown).

Table 7. Solar Radiation Productivity for grain and biomass production (kg (GJ PAR $\left.)^{-1}\right)$ in five cropping systems

\begin{tabular}{|c|c|c|c|c|c|c|}
\hline \multirow{3}{*}{ Crop } & \multicolumn{5}{|c|}{ Cropping systems } & \multirow{3}{*}{ Average } \\
\hline & Rice-Fallow & $\begin{array}{c}\text { Rice- } \\
\text { Soybean CT }\end{array}$ & $\begin{array}{c}\text { Rice-Soybean } \\
\text { MT }\end{array}$ & $\begin{array}{l}\text { Ridges and } \\
\text { Cattle }\end{array}$ & $\begin{array}{l}\text { Ridges and } \\
\text { Cover crops }\end{array}$ & \\
\hline & \multicolumn{5}{|c|}{$\mathrm{kg}(\mathrm{GJ} \text { PAR })^{-1}$} & \\
\hline Rice & $0.717(0.03)$ & $0.778(0.05)$ & $0.717(0.04)$ & - & & $0.737(0.02)$ \\
\hline Maize & - & & 8 & $0.810(0.08)$ & $0.594(0.05)$ & $0.709(0.06)$ \\
\hline Soybean & - & $0.168(0.01)$ & $0.187(0.02)$ & $0.233(0.01)$ & $0.221(0.01)$ & $0.206(0.01)$ \\
\hline $\begin{array}{l}\text { Crops } \\
\text { average }^{\text {a }} \\
\end{array}$ & $0.706(0.02)$ & $0.669(0.06)$ & $0.609(0.06)$ & $0.623(0.07)$ & $0.490(0.05)$ & - \\
\hline $\begin{array}{l}\text { System } \\
\text { average }\end{array}$ & $0.408(0.08) b$ & $0.471(0.09) a b$ & $0.456(0.08) \mathrm{ab}$ & $0.648(0.09) \mathrm{a}$ & $0.638(0.08) \mathrm{a}$ & - \\
\hline
\end{tabular}

a. Means weighted averaged by the amount of grains produced by each crop in the respective cropping system; the means are not significantly different $(p=0.25)$.

b. Yearly average; all food and biomass was included and considers the full time span of the experiment; means followed by the same letter are not significantly different at $p<0.05$.

Values between parentheses are the SEM.

\section{Theoretical number of persons fed per unit of land cultivated}

Taking account of the daily requirement of energy for an average person, the theoretical number of persons fed in one year by the food produced on one hectare varied from 12 to 26 (Figure 6). For the protein requirement, the values varied from six persons, in Rice-Fallow system, to 30 persons, in the Ridges and Cattle system. This result stems from the fact that the Rice-Fallow produced predominantly rice, which has low protein content. Despite the relatively high content of protein in the meat, the contribution of cattle to the overall protein production in the cropping systems was low. Cattle represented only $2 \%$ of food produced in the Rice-Fallow system and $3.2 \%$ and $1 \%$ for Ridges and Cattle, and Ridges and Cover crops, respectively. 


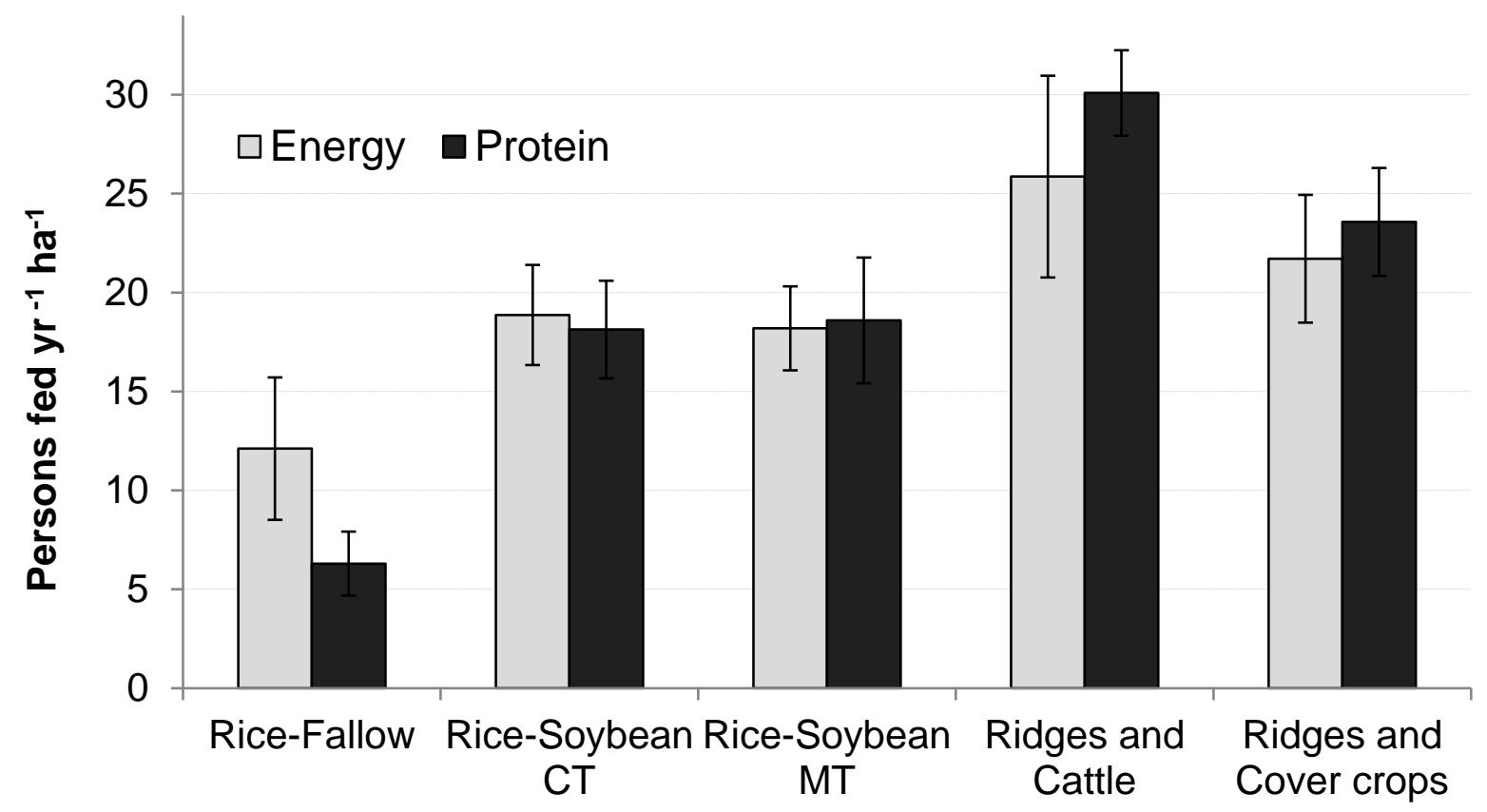

Figure 6. Number of persons fed in one year (PFY) by the food produced in a cropping system, based on daily requirements of energy and protein. Results are presented for five cropping systems in the lowlands of South Brazil. Average human daily consumption rates are set to 8.7 $\mathrm{MJ}$ for energy and $80 \mathrm{~g}$ for protein. Error bars indicate the SEM.

\section{Carbon-based footprints}

The carbon-footprint is a single, quantitative, but very robust indicator which integrates inputs and outputs to estimate the impact of the agricultural process in terms of the global warming perspective. The GHG Intensity Footprint represents the greenhouse gasses emitted per kg of food produced. The highest value for this indicator occurred in the Rice-Fallow system, with $3.3 \mathrm{~kg} \mathrm{CO}_{2}$-e kg-1 food (Table 8). When rice was rotated with soybean, GHG intensity was reduced with around $62 \%$. For the rice-soybean rotation the use of minimum tillage, instead of conventional tillage, represented a mitigation of $0.32 \mathrm{~kg} \mathrm{CO}_{2}$-e in emissions for each $\mathrm{kg}$ of food produced. The lowest values for this indicator occurred with the ridge-based systems, with around $0.62 \mathrm{~kg} \mathrm{~kg}^{-1}$. The GHG emissions per $\mathrm{kg}$ of food produced in the ridge-based systems represented a fraction of just 19\% in comparison with the Rice-Fallow system, and of 50\% compared to the rice-soybean systems.

The Personal GHG Footprint represents the ratio between the quantities of GHG emitted for each person a cropping system is able to feed, in a year. Rice-Fallow presented a Personal GHG Footprint 3.3 times higher than that calculated for the rice-soybean systems. For each person the rice-soybean rotations are able to feed in a year, $330 \mathrm{~kg} \mathrm{CO}$-e is emitted to the 
atmosphere. Also from this perspective, the ridge-based systems are more efficient as the emissions were reduced to around $120 \mathrm{~kg} \mathrm{CO}_{2}$-e per person. This value corresponds to a fraction of $11 \%$ of that of the Rice-Fallow system, and of $36 \%$ compared to the rice-soybean systems.

The footprints based on the carbon balance (indicators 3 and 4 in Table 8), included not just GHG emissions, but also the carbon effectively sequestered into the soil through organic matter. All cropping systems with irrigated rice were carbon-emitters and presented negative profiles related to the global warming potential. For each $\mathrm{kg}$ of food produced the rice-based systems effectively emitted between 1.0 and $3.1 \mathrm{~kg} \mathrm{CO}_{2}$-e to the atmosphere. When minimum tillage substituted conventional tillage in the rice-soybean rotation, $0.38 \mathrm{~kg} \mathrm{CO}_{2}$-e per $\mathrm{kg}$ of food produced was kept in the soil, instead of being emitted to the atmosphere. Again, the cropping systems conducted on ridges were more environmentally benign from this point of view. For each $\mathrm{kg}$ of food produced, the ridge-based systems sequestered an equivalent of 0.13 $\mathrm{kg} \mathrm{CO} 2$-e, on average (Table 8).

Table 8. Carbon-based footprint indicators in five cropping systems

Cropping Systems

\begin{tabular}{|c|c|c|c|c|}
\hline $\begin{array}{l}\text { Footprint } \\
\text { based on: }\end{array}$ & Rice-Fallow & $\begin{array}{c}\text { Rice-Soybean } \\
\text { CT }\end{array}$ & $\begin{array}{c}\text { Rice-Soybean } \\
\text { MT }\end{array}$ & $\begin{array}{l}\text { Ridges and } \\
\text { Cattle }\end{array}$ \\
\hline
\end{tabular}

\begin{tabular}{lccccc}
\cline { 2 - 5 } & \multicolumn{5}{c}{ GHG emitted / } \\
\hline 1) Food ${ }^{\mathrm{a}, \mathrm{c}}$ & $3.30(14.4)$ & $1.40(0.66)$ & $1.08(0.49)$ & $0.62(0.18)$ & $0.63(0.15)$ \\
2) PFY(energy), d & $1078(5472)$ & $371(190)$ & $287(145)$ & $118(35)$ & $121(27)$ \\
\hline & & \multicolumn{5}{c}{$\mathrm{CO}_{2}$-e balance / } \\
\hline 3) Food ${ }^{\mathrm{a}, \mathrm{c}}$ & $-3.08(13.25)$ & $-1.34(0.75)$ & $-0.98(0.62)$ & $0.10(0.29)$ & $0.15(0.17)$ \\
4) PFY(energy) & $-1005(5058)$ & $-356(203)$ & $-259(166)$ & $20(56)$ & $29(32)$
\end{tabular}

Name of indicators: 1) GHG Intensity Footprint; 2) Personal GHG Footprint; 3) $\mathrm{CO}_{2}$-e Footprint; 4) Personal $\mathrm{CO}_{2}$-e Footprint. All values presented are the medians followed by the respective SD. For footprints 3 and 4, negative values indicate net emissions to the atmosphere
a. Grains + gains in cattle live weight, in $\mathrm{kg} \mathrm{ha}^{-1}$.
b. $\mathrm{PFY}=$ Persons fed per ha per year, based on consumption of energy.
c. Units: $\mathrm{kg} \mathrm{CO}$-e/ $\mathrm{kg}$ food.
d. Units: $\mathrm{kg} \mathrm{CO}_{2}$-e/PFY.

The Personal $\mathrm{CO}_{2}$-e Footprint followed the same trend. The systems on ridges performed best. For each person the ridge-based systems were theoretically able to feed in one year, a net $24.6 \mathrm{~kg}$ of $\mathrm{CO}_{2}$-e was sequestered into the soil. The other cropping systems were 
carbon emitters. For each person Rice-Fallow was able to feed, $1005 \mathrm{~kg} \mathrm{CO}_{2}$-e was displaced to the atmosphere, and on average $309 \mathrm{~kg}$ was emitted by the rice-soybean rotations. If reduced tillage instead of conventional tillage was used in rice-soybean system, the emission into the atmosphere was reduced with around $100 \mathrm{~kg} \mathrm{CO}_{2}$-e for each person the system was able to feed.

\subsection{Discussion}

\section{General aspects}

The adoption of a novel cropping system by farmers requires a solid basis of convincing information (Rogers, 2010). For this reason, and to enable us to create a balanced picture of each cropping system evaluated, we conducted a detailed analysis of five systems using a wide variety of performance indicators, which included food production, land use, soil quality, resources use-efficiency and carbon balance. The values of these indicators differed considerably between the systems. Particularly, the two novel systems based on ridges exhibited yields, buildup of soil organic matter and resource-use efficiencies that exceeded that of the rice-based systems, whereas they also presented lower GHG emissions and GHG footprints. This shows how innovative changes in cropping systems can meet multiple demands on production, resource use and ecological sustainability.

Farmers in south-Brazilian lowlands have encountered difficulties with the irrigated rice production system, like for instance yield limitations and high costs associated to poor soil fertility (Bueno \& Lemos, 2006; Carmona et al., 2016) and herbicide resistant weeds (Goulart et al., 2014), which are spread out in many fields. Crop diversification is one of the keys to overcome such technical difficulties. Despite the positive characteristics of the rice-soybean rotation, further improvements that move beyond the mere transformation of a monoculture system into a simple crop rotation system are needed. Apart from technical motivations, the inclusion of multiple crops is also important to stimulate the development of industries at regional level, which constitutes a powerful driver for economic wealth, growth and job creation (Coronel et al., 2007). This wish-list was, in fact, at the basis of developing the two innovative ridge-based systems.

\section{Land use and food production}

Contrarily to the rice-based systems conducted in flat soils, the fields in the ridge-based systems are not water-saturated and are maintained free from flooding. This permits that no-tillage can 
be used for soil management, that a high amount of biomass can be produced during winter and that crop rotation is facilitated. Consequently, in this new system the three pillars of conservation agriculture (no-till, crop rotation and soil protection) are fulfilled (Palm et al., 2014). Flood avoidance is the primary reason why the ridge-based systems are beneficial for upland crops in lowlands. In the long run, however, also other soil-related aspects became apparent, of which the increase in soil organic matter is probably one of the most important points. Since the ridges keep the soil dry, the oxygen levels in the root zone can be more appropriate for plants than in the flat soils. Consequently, root growth (Guo et al., 2015), nutrient absorption (Elzenga \& van Veen, 2010) and the incorporation of atmospheric $\mathrm{N}_{2}$ by leguminous crops (Roberts et al., 2010) can be more efficient in the ridge-based systems than in the easily waterlogged, flat-soil systems.

We found that soil fertility in the ridge-based systems increased between 2006 and 2015, especially for OM and P levels. Evidence points out that the large amount of residual biomass and the presence of cattle in the field were probably responsible for this improvement (Faccio Carvalho et al., 2010; Fageria, 2012). The benefits of an improved soil fertility were likely reinforced through the bacterial biomass from the decomposing residues (Paul, 2014) and the manure (Braos, 2013), since both act as source of labile nutrients. In contrast to the improvements verified in ridge-based systems, P- and K-levels in the Rice-Fallow system reduced. In this system, the amount of crop residues and organic matter in the soil were probably insufficient to prevent the nutrients from leaching or to be transformed into a not promptly available form, as previously reported by Ferreira et al. (2011).

In the current study, the combination of extended use of land and the positive effects on soil fertility clearly benefited the productivity of crops, pastures and cover crops cultivated in the ridge-based systems. Besides the high grain yields obtained with the cash crops, the adequate level of soil humidity promoted by the ridges supported winter cultivation at a point that total annual biomass production was up to 33 times greater on the ridges than on flat areas. The differences between the cropping systems also spread into aspects like the quality of the food produced. In the ridge-based systems the produced food contained a higher protein-energy ratio (1.12:1) compared to the food in the rice-based systems $(0.76: 1)$. It is well established that the substitution of animal protein by plant protein in the human diet can reduce the negative environmental footprint caused by meat production and consumption (Gephart et al., 2016). However, while the change in consumption habits is a personal decision from the consumer 
(Raphaely \& Marinova, 2014), the adequate provision of plant proteins depends on versatile farming systems.

Next to biomass production and food quality, the fraction of time fields were occupied with crops revealed a substantial difference between the cropping systems. In the systems with irrigated rice, fallow was maintained throughout the winter, with limited biomass production from spontaneous vegetation. This condition is similar to what happens in many commercial farms in lowlands, where soil restrictions associated to waterlogging restrict the development of species not adapted to such condition. Keeping a field fallow after a season of irrigated rice is not a choice, but a common situation forced by the frequent waterlogging. This limitation is an important reason why most of the winter cover crops traditionally used in the uplands in south Brazil are almost not cultivated in the lowlands. During summer, on the other hand, the length of time the fields were used was roughly similar between the cropping systems, except for Rice-Fallow. In this simple cropping system, the three-year interval between the seasons of rice cultivation diminishes the effective land use. In contrast, in the ridge-based systems all available time was used for agricultural production, be it with cash crops, pastures or cover crops. Compared to the rice-based models, the novel ridge-based systems effectively intensify the land use in wetlands.

\section{Resources use-efficiency}

Although the system based on rice and fallow used the lowest amount of energy, its net energy ratio, which indicates how efficiently the energy was used, was the lowest between the cropping systems evaluated. This simple farming system required fifty-six percent more energy to produce one unit of food than the ridge-based cropping systems, on average. The efficiency of the Rice-Fallow would benefit from the introduction of some feasible, low-energy demanding practices. For example, the construction of channels in the field during fallow, to avoid waterlogging, is likely to increase the biomass production of native pastures or cover crops. Subsequent actions would be a seeding of improved pastures and the provision of an adequate level of nutrients, which could enhance soil protection, simultaneously to improving gains in cattle weight. Since the crop-livestock integration is the larger production system in the lowlands of southern Brazil, and perhaps of all temperate South America (Cid et al., 2011), these relatively simple adjustments would result in considerable gains at both farm and regional levels. The systems based in the ridges already incorporated most of these practices, and turned out to be the most efficient cropping system in terms of energy use. 
Water productivity from the ridge-based systems was almost twice that of the other production systems. This result largely stems from the high water-use efficiency of maize and from the presence of pastures and cover crops during wintertime. The ridge-based systems also presented higher efficiency on capturing the photosynthetically active radiation to produce biomass. The cultivation of maize, the better conditions for soybean growth, and the extended time the land was effectively cultivated, without wasting photosynthetically active radiation on fallow, positively affected the SRP index of these systems. For example, soybean produced on ridges used the PAR almost thirty percent more efficiently than the soybean produced on flat fields within the rice-soybean rotations. The innovative cropping system supplied more favorable conditions for the crop to use the available light and to express its yield potential.

\section{Environmental issues and Footprints}

The soil is an essential component related to carbon emission and carbon sequestration by agricultural systems. Collected data show that the systems based on irrigated rice were net carbon emitters, while the systems based on the ridges sequestered carbon. The high $\mathrm{C}$ accumulation in the ridge-based systems are in agreement with earlier reported results for notillage fields (Costa et al., 2008). The model of production adopted in the ridges adequately join minimum soil disturbance with high organic matter input, which are the two fundamental keys supporting carbon sequestration into the soil (Ghimire et al., 2012). In fact, the ridge-based systems were able to convert "carbon-emitting lands" into "carbon-uptake lands" as stated by Morse (2010). On the other hand, the rice-based systems presented a negative $\mathrm{CO}_{2}$-e balance, mainly stemming from large fuel consumption and carbon emission connected to soil preparation, the low amount of plant residues effectively incorporated as soil organic matter, and the emissions of methane from the flooded fields.

Greenhouse gas emissions and the $\mathrm{CO}_{2}$-e balance, which represents the global warming impact of a production system, are key factors in the evaluation of agricultural sustainability nowadays (Glendining et al., 2009). The four carbon-based footprint indices analysed in this study all presented a similar tendency, with the cropping systems conducted on ridges being less adverse to the environment than the other systems. Within the rice-soybean systems, the carbon-based footprints obtained for minimum-tillage were markedly better than those obtained with conventional tillage. For all four indices assessed, the Rice and Fallow system presented the least favourable profile. This result was partially unexpected, since this cropping system is very simple and consumed the lowest amount of energy. However, apart from energy use, the 
Rice and Fallow combines a discontinuous and limited production of food and biomass with a nearly continuous emission of GHG, and this is what is reflected in the footprint indices. From this perspective, the ridge-based systems seem to adequately balance food production with environmental preservation.

\subsection{Conclusions}

The cropping system based on irrigated rice and fallow requires less energy to run and is one of the simplest production models to be carried out in the lowlands. It is the logical choice for most wetland fields in south Brazil, since rice is adapted to the hydromorphic environment, and beef cattle - an important activity at regional level - can be placed in the paddies during the fallow period. However, this system presented the most adverse results for several indicators, especially for those related to energy use efficiency and ecosystems services, like the carbonbased footprints. For most indicators evaluated, the rice-soybean systems represent an improvement over the Rice-Fallow, particularly if rice-soybean is conducted in minimumtillage. The main advantages of using minimum-tillage instead of conventional tillage in the rice-soybean rotation are related to energy use, carbon emission and carbon sequestration. These desirable outcomes from minimum-tillage in the rice-soybean rotation were accompanied by a similar total biomass production, thus resulting in an improved performance in the carbon-based footprint indicators.

The ridge-based cropping systems are conceptually very different from the systems maintained in flat soils. Besides the technical differences, the ridge systems presented better results than the other production models on important characteristics like soil quality, biomass production, carbon sequestration, GHG emission and water- and PAR use-efficiency. Importantly, as the ridge-based systems neutralize waterlogging, the systems also showed a much higher productivity of maize than the regional benchmarks.

Of the two ridge-based systems evaluated, the Ridges and Cattle often performed slightly better than the Ridges and Cover crops system. This better performance was reflected in a diverse set of indicators, like grain production $(+18 \%)$, carbon sequestered as soil organic matter $(+12 \%), \mathrm{CO}_{2}$-e balance (Global Warming Impact; $\left.-46 \%\right), \mathrm{P}$ accumulated in soil $(+346 \%)$, water productivity for maize $(+43 \%)$, solar radiation productivity for maize $(+36 \%)$, energy produced in food $(+19 \%)$ and protein produced in food $(+27 \%)$. These results confirm the benefits from including pastures and cattle in a well-planned rotation scheme with grain crops. These observations are in line with milestone reports from De Moraes et al. (2014) and 
Ruviaro et al. (2016) who highlight the importance of crop-livestock integration for the sustainability of several production systems in Brazil and other South-American countries. The current result makes evident that the adoption of large ridge-based cropping systems is a viable alternative to the wetland paddies which are temporarily or permanently not used for irrigated rice cultivation. In our view, the ridge-based concept is a promising route to a diversified and more sustainable agriculture in the lowlands.

\subsection{Acknowledgements}

We are very thankful to all the staff from the Lowlands Experimental Station and to Embrapa Clima Temperado, Pelotas, Brazil. This work was funded by the Brazilian Agricultural Research Corporation (Embrapa). The authors declare there is no conflict of interests regarding this research.

\subsection{References}

Aita C \& GiACOMIni S (2003) Decomposição e liberação de nitrogênio de resíduos culturais de plantas de cobertura de solo solteiras e consorciadas. Revista Brasileira de Ciencia do Solo 27, 601-612.

Alipour A, Veisi H, Darijani F, Mirbagheri B \& Behbahani A (2012) Study and determination of energy consumption to produce conventional rice of the Guilan province. Research in Agricultural Engineering 58, 99-106.

Alvares CA, Stape JL, Sentelhas PC, de Moraes Goncalves JL \& Sparovek G (2013) Koppen's climate classification map for Brazil. Meteorologische Zeitschrift 22, 711728.

Andres A, Concenco G, Theisen G, Galon L \& Tesio F (2012) Management of red rice (Oryza sativa) and barnyardgrass (Echinochloa crus-galli) grown with sorghum with reduced rate of atrazine and mechanical methods. Experimental Agriculture 48, 587596.

Assis FN \& MENDEZ MEG (1989) Relação entre radiação fotossinteticamente ativa e radiação global. Pesquisa Agropecuária Brasileira 24, 797-800.

ASSMANN JM, ANGHINONi I, MARTINS AP et al. (2015) Carbon and nitrogen cycling in an integrated soybean-beef cattle production system under different grazing intensities. Pesquisa Agropecuária Brasileira 50, 967-978.

Audsley E, Stacey K, PARsons DJ \& Williams AG (2009) Estimation of the greenhouse gas emissions from agricultural pesticide manufacture and use. 20. Cranfield University, Bedford, UK.

Balbinot Junior AA, Moraes Ad, Veiga Md, Pelissari A \& Dieckow J (2009) Integração lavoura-pecuária: intensificação de uso de áreas agrícolas. Ciencia Rural 39, 1925-1933.

BAYer C, ZsChORnack T, SousA RO et al. (2013) Strategies to Mitigate Methane Emissions in Lowland Rice Fields in South Brazil. Better Crops with Plant Food 97, 27-29. 
BOWERS W (1992) Agricultural field equipment. In: Energy in farm production, Vol. 6. (ed RC Fluck), 1 edn, 117-130. Elsevier, Amsterdam.

BRAOS LB (2013) Fracionamento do fósforo orgânico em solo adubado com esterco bovino. Master Master Thesis, Universidade Estadual Paulista Júlio de Mesquita Filho, Jaboticabal, SP, Brazil.

BRENTRUP F, KÜSTERS J, KUHLMANN H \& LAMMEL J (2004) Environmental impact assessment of agricultural production systems using the life cycle assessment methodology: I. Theoretical concept of a LCA method tailored to crop production. European Journal of Agronomy 20, 247-264.

BuENO AdCES \& LEMOS CAS (2006) Levantamento da fertilidade do solo cultivado com arroz irrigado no município de Uruguaiana. Revista da FZVA 13, 41-51.

CAmpillo C, Fortes R \& Prieto MdH (2012) Solar Radiation Effect on Crop Production. In: Solar Radiation, Vol. 1. (ed EB Babatunde), 494. InTech.

CAMPOS AT \& CAMPOS ATD (2004) Balanços energéticos agropecuários: uma importante ferramenta como indicativo de sustentabilidade de agroecossistemas. Ciencia Rural 34, 1977-1985.

Carmona FdC, Anghinoni I, Mezzari CP, Martins AP \& Carvalho PCdF (2016) Effectiveness of current fertilizer recommendations for irrigated rice in integrated croplivestock systems. Revista Brasileira de Ciencia do Solo 40.

CARVAlHo PTD (2012) Balanço de emissões de gases de efeito estufa de biodiesel produzido a partir de soja e dendê no Brasil. Master, Universidade Federal do Rio de Janeiro, Rio de Janeiro, Brazil.

Cid MS, Grecco RCF, Oesterheld M, Paruelo JM, Cibils AF \& Brizuela MA (2011) Grass-fed beef production systems of Argentina's flooding pampas: Understanding ecosystem heterogeneity to improve livestock production. Outlook on Agriculture 40, 181-189.

Comissão De Química e Fertilidade do Solo - RS/SC (2004) Manual de Adubacao e Calagem para os Estados do Rio Grande do Sul e de Santa Catarina, (ed. SBDCD SoloCqfs), 2 edn. SBCS-CQFS, Porto Alegre.

Coronel DA, Alves FD \& Silva MAE (2007) Notas sobre o processo de desenvolvimento da metade sul e norte do estado do Rio Grande do Sul: uma abordagem comparativa. Perspectiva Econômica 3, 27-43.

Costa FdS, BAyer C, Zanatta JA \& MielniczuK J (2008) Estoque de carbono orgânico no solo e emissões de dióxido de carbono influenciadas por sistemas de manejo no sul do Brasil. Revista brasileira de ciencia do solo. Campinas. Vol. 32, n. 1 (jan./fev. 2008), p. 323-332.

De Moraes A, Carvalho PCDF, Anghinoni I, Lustosa SBC, Costa SEVGDA \& KunRath TR (2014) Integrated crop-livestock systems in the Brazilian subtropics. European Journal of Agronomy 57, 4-9.

Durno J, Moeliono I, Prasertcharoensuk R \& Network SASA (1992) Resource Book on Sustainable Agriculture for the Lowlands. Southeast Asia Sustainable Agriculture Network.

ELZENGA JTM \& VAN VEEN H (2010) Waterlogging and plant nutrient uptake. In: Waterlogging Signalling and Tolerance in Plants. (eds S Mancuso \& S Shabala), 23-35. Springer 
Berlin Heidelberg, Berlin, Heidelberg.

EMBRAPA (2012) Indicações técnicas para a cultura da soja no Rio Grande do Sul e em Santa Catarina, safras 2012/2013 e 2013/2014. In: XXXIX Reunião de Pesquisa de Soja da Região Sul, Vol. Documentos, 7. (ed Leila Maria Costamilan [Et Al.]), 1 edn, 142. Embrapa Trigo, Passo Fundo.

ERASMo EAL, Pinheiro LLA \& Costa NV (2004) Levantamento fitossociológico das comunidades de plantas infestantes em áreas de produção de arroz irrigado cultivado sob diferentes sistemas de manejo. Planta Daninha 22, 195-201.

ERIKSSON M \& AHLGREN S (2013) LCAs for petrol and diesel - a literature review. 36. Swedish University of Agricultural Sciences, Uppsala.

EVeraArts AP, NeEteson JJ, HuOng PTT \& StRUik PC (2015) Vegetable Production after flooded rice improves soil properties in the Red River delta, Vietnam. Pedosphere 25, 130-139.

Faccio Carvalho PC, Anghinoni I, Moraes A et al. (2010) Managing grazing animals to achieve nutrient cycling and soil improvement in no-till integrated systems. Nutrient Cycling in Agroecosystems 88, 259-273.

FAGERIA NK (2012) Role of Soil Organic Matter in Maintaining Sustainability of Cropping Systems. Communications in Soil Science and Plant Analysis 43, 2063-2113.

FeIX RD \& Leusin JR. S (2015) Painel do Agronegócio no Rio Grande do Sul - 2015., Vol. 1. (ed Fee), 1 edn, 44. FEE, Porto Alegre, RS, Brazil.

FERreira EVdO, ANGHINONI I, ANDRIGHETti MH, MARTins AP \& CARVAlHo PCDF (2011) Ciclagem e balanço de potássio e produtividade de soja na integração lavoura-pecuária sob semeadura direta. Revista Brasileira de Ciencia do Solo 35, 161-169.

FERREIRA FDF, NEUMANN PS \& HOFFMANN R (2014) Análise da matriz energética e econômica das culturas de arroz, soja e trigo em sistemas de produção tecnificados no Rio Grande do Sul. Ciencia Rural 44, 380-385.

FERTILIZERS EUROPE (2014) Carbon footprint reference values: energy efficiency and greenhouse gas emissions in european mineral fertilizer production and use. 5. Fertilizers Europe, Brussels.

FUKSA P, HAKL J \& BRANT V (2013) Energy balance of catch crops production. ZemdirbysteAgriculture 100, 355-362.

Gephart JA, Davis KF, Emery KA, Leach AM, Galloway JN \& Pace ML (2016) The environmental cost of subsistence: Optimizing diets to minimize footprints. Science of The Total Environment 553, 120-127.

Ghimire R, AdHIKARI KR, ChEn ZS, Shah SC \& DAHAL KR (2012) Soil organic carbon sequestration as affected by tillage, crop residue, and nitrogen application in rice-wheat rotation system. Paddy and Water Environment 10, 95-102.

Glendining MJ, Dailey AG, Williams AG, Evert FKv, Goulding KWT \& Whitmore AP (2009) Is it possible to increase the sustainability of arable and ruminant agriculture by reducing inputs? Agricultural Systems 99, 117-125.

Goulart ICGR, Borba TCO, Menezes VG \& Merotto A (2014) Distribution of weedy red rice (Oryza sativa) resistant to imidazolinone herbicides and its relationship to rice cultivars and wild Oryza species. Weed Science 62, 280-293. 
GUO LJ, ZHANG RD, ZHANG ZS, CAO CG \& Li CF (2015) Effects of different no-tillage modes on soil $\mathrm{CO} 2$ fluxes from paddy fields in central China. Journal of soil science and plant nutrition 15, 737-750.

HeICHEL GH (1980) Assessing the fossil energy costs of propagating agricultural crops. In: Handbook of energy utilization in agriculture, Vol. 1. (ed D Pimentel), 27-33. CRC Press, Boca Raton, FL, USA.

HOKAZONO S \& HAYASHI K (2015) Life cycle assessment of organic paddy rotation systems using land- and product-based indicators: a case study in Japan. The International Journal of Life Cycle Assessment 20, 1061-1075.

IBGE (2015) IBGE - Produção Agrícola Municipal. In: Monthly. Instituto Brasileiro de Geografia e Estatistica, Brasilia, Brasil.

IBGE (2016) Banco de Dados Agregados (Aggregated Database). Available at: http://www.sidra.ibge.gov.br/ (accessed 05 Jan 2017).

IPCC (2006) 2006 IPCC Guidelines for National Greenhouse Gas Inventories. Agriculture, Forestry and Other Land Use., (eds. K Paustian, NH Ravindranath \& AV Amstel). Institute for Global Environmental Strategies, Hayama, Japan.

KIJNE JW, BARKER R \& MOLDEN D (2003) Water productivity in agriculture: limits and opportunities for improvement.

KomAtsuZAKI M \& OHTA H (2007) Soil management practices for sustainable agroecosystems. Sustainability Science 2, 103-120.

Lima ACR, Hoogmoed WB, Pauletto EA \& Pinto LFS (2009) Management systems in irrigated rice affect physical and chemical soil properties. Soil \& Tillage Research 103, 92-97.

Lima MAd, Pesso MCPY, Neves MC \& CARVAlho ECD (2010) Emissões de metano por fermentação entérica e manejo de dejetos de animais. In: Segundo Inventário Brasileiro de Emissões e Remoções Antrópicas de Gases de Efeito Estufa - Relatórios de Referência. (ed Embrapa/Mct), 2010 edn, 121. Ministerio de Ciência e Tecnologia, Brasília, DF, Brazil.

LunN DJ, Thomas A, Best N \& Spiegelhalter D (2000) WinBUGS - A Bayesian modelling framework: Concepts, structure, and extensibility. Statistics and Computing 10, 325337.

MANTOAM EJ, RomAnelLi TL \& GiMENEZ LM (2016) Energy demand and greenhouse gases emissions in the life cycle of tractors. Biosystems Engineering 151, 158-170.

MORSE S (2010) Sustainability: a biological perspective. Cambridge University Press.

Nishimura S, Akiyama H, Sudo S, Fumoto T, Cheng W \& Yagi K (2011) Combined emission of $\mathrm{CH} 4$ and $\mathrm{N} 2 \mathrm{O}$ from a paddy field was reduced by preceding upland crop cultivation. Soil Science and Plant Nutrition 57, 167-178.

Niu W, Han L, LiU X, Huang G, Chen L, XIAo W \& Yang Z (2016) Twenty-two compositional characterizations and theoretical energy potentials of extensively diversified China's crop residues. Energy 100, 238-250.

Palm C, Blanco-Canqui H, DeClerck F, Gatere L \& Grace P (2014) Conservation agriculture and ecosystem services: an overview. Agriculture Ecosystems and Environment 187, 87-105. 
PAUl EA (2014) Soil microbiology, ecology and biochemistry. Academic press.

PIMENTEL D (1992) Energy inputs in production agriculture. In: Energy in farm production, Vol. 6. (ed RC Fluck), 1 edn, 13-29. Elsevier, Amsterdam.

Poorter H, Niklas KJ, Reich PB, Oleksyn J, Poot P \& Mommer L (2012) Biomass allocation to leaves, stems and roots: meta-analyses of interspecific variation and environmental control. New Phytologist 193, 30-50.

RAPHAEly T \& MARINOVA D (2014) Flexitarianism: Decarbonising through flexible vegetarianism. Renewable Energy 67, 90-96.

REUNIÃO TÉCNICA ANUAL DO MILHO RTADS, 41. (2013) Indicações técnicas para o cultivo de milho e de sorgo no Rio Grande do Sul safras 2013/2014 e 2014/2015., (ed. APSaDR Beatriz Marti Emygdio, Mauro Cesar Celaro Teixeira). Embrapa, Brasília, Brazil.

RoBerts DM, CHOI WG \& HwANG JH (2010) Strategies for Adaptation to Waterlogging and Hypoxia in Nitrogen Fixing Nodules of Legumes. In: Waterlogging Signalling and Tolerance in Plants. (eds S Mancuso \& S Shabala), 37-59. Springer Berlin Heidelberg, Berlin, Heidelberg.

Rogers EM (2010) Diffusion of innovations, Fourth edn. The Free Press, New York.

Rosa CMd, Castilhos RMV, Pauletto EA, Pillon CN \& Leal OdA (2011) Conteúdo de carbono orgânico em planossolo háplico sob sistemas de manejo do arroz irrigado. Revista Brasileira de Ciencia do Solo 35, 1769-1776.

Ruviaro CF, DA COSTA JS, Florindo TJ, Rodrigues W, DE MEDEIROS GIB \& VASCONCELOS PS (2016) Economic and environmental feasibility of beef production in different feed management systems in the Pampa biome, southern Brazil. Ecological Indicators 60, 930-939.

SÁ JM, UrQuiaga S, Jantalia CP et al. (2013) Energy balance for the production of grain, meat, and biofuel in specialized and mixed agrosystems. Pesquisa Agropecuária Brasileira 48, 1323-1331.

SANTOS IAD \& NOGUEIRA LAH (2012) Estudo energético do esterco bovino: seu valor de substituição e impacto da biodigestão anaeróbia. Revista Agroambiental 4, 41-49.

SAS Institute (2016) The SAS system for Windows. Version 9.4. Cary, NC.

SCHIPANSKI ME, BARBERCHECK M, Douglas MR et al. (2014) A framework for evaluating ecosystem services provided by cover crops in agroecosystems. Agricultural Systems $125,12-22$.

SOSBAI (2014) Arroz irrigado: recomendações técnicas da pesquisa para o sul do Brasil, (ed. Sosbai), 1 edn. Sociedade Sul Brasileira de Arroz Irrigado, Santa Maria, RS, Brazil.

Streck EV, Kämpf N, Dalmolin RSD et al. (2008) Solos do Rio Grande do Sul. 2a Ed. UFRGS, Departamento de Solos, Faculdade de Agronomia and EMATER/RS, Porto Alegre, RS, Brazil.

TeIXeira EI, Johnstone P, Chakwizira E et al. (2016) Sources of variability in the effectiveness of winter cover crops for mitigating N leaching. Agriculture, Ecosystems and Environment 220, 226-235.

Vernetti Junior FJ, Gomes AS \& Schuch LOB (2009) Sustentabilidade de sistemas de rotação e sucessão de culturas em solos de várzea no Sul do Brasil. Ciencia Rural 39, $1708-1714$ 
Weller S, JANZ B, JÖRG L et al. (2016) Greenhouse gas emissions and global warming potential of traditional and diversified tropical rice rotation systems. Global Change Biology 22, 432-448. 


\section{Chapter 3}

\section{Use of a multi-criteria approach to evaluate five agricultural cropping systems in lowlands}




\title{
Use of a multi-criteria approach to evaluate agricultural cropping systems in lowlands ${ }^{1}$
}

\author{
Giovani Theisen *†; Lammert Bastiaans $\uparrow$ \\ *Embrapa Temperate Climate, BR 392, km 78, 96010-970, Pelotas, RS, Brazil, \\ $\uparrow$ Centre for Crop System Analysis, Wageningen University, Wageningen, Netherlands
}

\begin{abstract}
The objective of this work was to evaluate the performance of a total of five prevailing and novel cropping systems for lowlands in the temperate region of South America. A multi-criteria assessment was conducted by collecting nine years of field data and examining this information using Process Analysis (PA) followed by the creation of Key Performance Indicators (KPI). The five cropping systems under study were: a) irrigated rice - fallow (3-yr rotation); rice-soybean (2-yr rotation) cultivated in either b) conventional tillage; or c) minimum tillage; and two novel systems, for which the originally flat, humid wetland soil was turned into permanent large ridges, on which maize and soybean (2-yr rotation) were cultivated in no-tillage, with either d) crop-livestock integration; or e) winter cover crops. The experiment started in mid-2006 extending up to mid-2015, in the Lowlands Experimental Station of Embrapa, near Pelotas, in south of Brazil. The area of each system varied from 3 to 11 ha, and all machinery, inputs, production techniques and labour followed similar routines as used in commercial farms. Data collected were food produced (rice, maize, soybean and cattle weight gains), crop, cover crop and pasture biomass, energy (in and out), labour time, prices (inputs and outputs), as well as the records of all inputs used, by type and amount, over the entire time span of 9-years. Cropping systems were decomposed in a series of technical processes (the Process Analysis (PA) step), including soil preparation, seeding, plant nutrition, irrigation, pest management, cattle management, harvest and transports. A total of twenty-one primary indicators were generated, standardized and finally aggregated into five KPIs, representing five dimensions of sustainability (environment, land production, economics, energy use-efficiency and labour). The traditional Rice-Fallow required less energy, presented the lowest cost and used less pesticides than the other cropping systems. However, this system appeared to be non-land-saving, as it produced the lowest amount of food per ha per year. Consequently, rice-fallow exhibited the weakest performance in four out of five KPIs and only for the environmental dimension it achieved well. A remarkable divergence following the differences in soil management was observed between the two rice-soybean rotations. Minimum-tillage saved energy and labour, but such savings were substituted, in a similar proportion, by herbicides. Both ridge-based systems stood out because of their high biomass production. However, if priority was given to cover crops instead of the consumption of excessive biomass by cattle, economic benefits nor immediate savings in fertilizer and pesticide use
\end{abstract}

\footnotetext{
${ }^{1}$ Article in preparation
} 
were obtained. The paper presents robust evidence that the large-ridge based system used for croplivestock integration represents a good option for sustainable intensification of the lowlands. The combination of Process Analysis and Key Performance Indicators proofed valuable for this type of multiple criteria assessment, as it was able to detect and quantify small and large differences between cropping systems.

Keywords: agriculture, cropping systems, indicators, sustainability, wetlands

\subsection{Introduction}

One of the main challenges of modern agriculture is to increase production levels to meet the increasing demand for food. To satisfy such requirement, many agricultural systems have increased primary production, while relying on a larger input use. The 'high input to high output' approach, despite its ability to increase food production (Kong et al., 2014; Witzke \& Noleppa, 2016), has shown its drawbacks in term of environmental costs (Norse \& Ju, 2015; Pandey \& Agrawal, 2015). The expansion of agriculture to new areas, which was an obvious solution in the past (FAO, 2003; Barretto et al., 2013), is not a plausible option anymore for several countries. Beside inherent technical restrictions (Alexandratos \& Bruinsma, 2012; Filipe et al., 2013), farm land expansion has been charged with issues as social costs (Meyfroidt et al., 2014), conflicts (Cáceres, 2015) and biodiversity loss (Coe et al., 2013). A critical thinking exists (Nature, 2010; Pretty et al., 2011) that innovations and the design of new cropping systems are needed to meet the challenges and demands for a larger and more sustainable agricultural production (Foley et al., 2011).

Brazil is a big player in agricultural production world-wide and it is the largest rice producer outside of Asia. Most of Brazilian's rice is produced in lowlands in the south of the country (Fageria et al., 2014). Historically, these wetlands have been cultivated with irrigated rice, integrated at variable levels with beef-cattle production. Southern Brazilian lowlands represent strategic agricultural systems, since $70 \%$ of rice, the main food for most Brazilians, is produced in these fields (IBGE, 2016). Large programs to optimize regional rice production were successful (Gomes et al., 2004; Menezes et al., 2012), and the current grain yield in south Brazil is around 7.2 tonnes per hectare (SOSBAI, 2014). However, as rice grain yield increased, problems like herbicide resistant weeds (Menezes et al., 2009; Goulart et al., 2014) and yield restrictions due to limited soil fertility (Bueno \& Lemos, 2006) turned into important issues. Along with these technical difficulties, negative impacts from intensive farming in lowlands, 
as the carryover of pesticides (Grützmacher et al., 2008; Bundt et al., 2013; Back et al., 2016) and nutrients (Silva et al., 2011) to water systems, high energy costs (Ferreira et al., 2014), and high monetary risk (Haveman, 2013) became relevant. To deal with this situation, innovations based on incremental improvements in rice production (Menezes et al., 2012; Pittelkow et al., 2016), and rotation of irrigated rice with crops like soybean (Vernetti \& Vernetti Jr., 2013) were proposed and are gradually being introduced in these farming systems.

In this paper, five cropping systems for the lowlands were evaluated. Next to the traditional and locally predominant system based on rice and fallow, we analysed two cropping systems based on rice-soybean rotation, and two new systems in which crops, pastures and cover crops are cultivated in a flood-free field, managed on large ridges. These new cropping systems were designed with a clear focus on the applicability for the end-user (Prost et al., 2012), aiming at sustainable intensification and conservation agriculture. A detailed description and analysis of these production systems in a long-term perspective, however, is still missing.

To comprehend these cropping systems and to assess their performance, a novel multicriteria approach based on a combination of Process Analysis (PA) and Key Performance Indicators (KPIs) was framed. PA is a mechanistic technique for system's analysis in which the system is decomposed in a series of logical stages, each stage defined as a basic segment of the farm production activity. The processes considered for this study were soil preparation, seeding, plant nutrition, irrigation, pest management, harvest, transports and cattle management. Key Performance Indicators are measurable values that demonstrate how efficiently an enterprise is achieving its goals (Parmenter, 2015). In the current analysis, we adapted the performance indicator's concept to analyse how the cropping systems succeed with regards to five distinct dimensions of sustainability (the goals): environmental impact, primary land production, economics, energy use-efficiency and labour. Usually applied in the fields of engineering and Business Intelligence, PA and KPIs are relatively new for agricultural system analysis. Recent reports in which these techniques were used however (e.g. Bimonte et al. (2016); Peral et al. (2017)), show that these methods are adequate to understand and contrast complex agricultural systems.

A broad performance measurement is crucial to understand and to develop clever strategies to improve a system (Dejaco et al., 2017). In this way, shortcomings and 'obvious anomalies' (Farrell, 1957) of judging complex models based on single-criterion approaches (Lin \& Hülsbergen, 2017) or mono-dimensional perspectives (Niedertscheider et al., 2016) are prevented. Based on these principles, the aim of this study was to assess the performance of 
cropping systems using a combination of Process Analysis and Key Performance Indicators. An important aspect of this work was that the comparisons of different systems were done under identical site conditions, in a long-term perspective and by using the same approach across the systems. A novelty of this study is that for the first time Process Analysis and Key Performance Indicators were combined for an integrated assessment of agricultural cropping systems.

\subsection{Material and methods}

\section{Site description}

This study was conducted in the Embrapa Lowlands Experimental Station (LES), near Pelotas, state of Rio Grande do Sul, southern Brazil (31.8134 S; 52.4736 W). The experiment started in May 2006 and finished in April 2015, after 9 cropping seasons (schemed in item B in the Supplementary Section). Five cropping systems were established in a uniform, 33-ha area inside LES. The terrain is very flat, with the soil classified as Solodic haplic eutrophic Planosol. Soil analysis was done on a regular basis for each cropping system. Average soil bulk density was $1.49 \mathrm{~kg} \mathrm{dm}^{-3}$, with $283 \mathrm{~g} \mathrm{dm}^{-3}$ clay, $551 \mathrm{~g} \mathrm{dm}^{-3}$ silt and $608 \mathrm{~g} \mathrm{dm}^{-3}$ sand. The area is located at $13 \mathrm{~m}$ above sea level and the climate is humid temperate ( $\mathrm{Cfa}$, according to Köppen's classification). During the experimental period, the mean temperature was $18.1^{\circ} \mathrm{C}$ and the yearly precipitation averaged $1343 \mathrm{~mm}$.

The five production systems, for which a description is included below, varied in size between 3.1 and 11.0 hectares. Their names and essential characteristics are described:

a) Rice and fallow ("Rice-Fallow"): dry-seeded irrigated rice with minimum-till soil management, cultivated for three consecutive cropping seasons, followed by a three-year interval without rice. During the fallow period, cattle for meat production occupied the fields (1.1 head ha-1).

b) Rice and soybean, cultivated in conventional tillage ("Rice-Soybean CT"): dry-seeded irrigated rice cultivated for two consecutive cropping seasons, followed by two seasons of rainfed soybean. Main soil preparation using plough, harrow and leveling was performed in winter. In the next spring, just prior to seeding of the summer crop, one additional light harrowing was conducted as seedbed preparation.

c) Rice and soybean, cultivated in minimum tillage ("Rice-Soybean MT"): The same as (b) but soil preparation was performed immediately after rice harvest, in autumn; the soil was not prepared after harvesting soybean. Crops were seeded with a no-tillage seeder, after 
herbicidal control of spontaneous vegetation using glyphosate.

d) Rainfed crops integrated with beef-livestock, placed over large-based ridges ("Ridges and Cattle"): soybean and maize cultivated sequentially (one crop per summer season) in notillage, on permanent large ridges ( $8.0 \mathrm{~m}$ wide and $0.4 \mathrm{~m}$ high in the centre (Figure 1)), constructed in mid-2006. In the winter seasons, the field was cultivated with pastures composed of Italian ryegrass (Lolium multiflorum Lam.) and black oats (Avena strigosa Schreb.). Beef cattle was placed on the pastures in winter, at a stocking rate adjusted to maintain a forage allowance of $12 \%$; i.e. $12 \mathrm{~kg}$ of dry mass (DM) per $100 \mathrm{~kg}$ of cattle weight per day. Herbicidal control of the remaining vegetation was performed before seeding soybean and maize.

e) Rainfed crops integrated with cover crops, placed over large-based ridges ("Ridges and Cover crops"): the same as (d) except that during winter time the field was cultivated with cover crops (a mix of Italian ryegrass, black oats, hairy vetch (Vicia sativa L.) and radish (Raphanus sativus L.)).

All crops followed the regional standards for field and pest management, using pesticides and critical levels of control according to the official guidelines. For irrigated rice, irrigation started approximately at 21 days after crop emergence, and a water layer of around $10 \mathrm{~cm}$ was maintained up to harvest.

\section{Data acquisition}

\section{Grain yield, other plant biomass and beef-cattle production}

Grain yield of maize, rice and soybean was assessed by collecting samples of crops (hand harvested) just before combine harvesting. Individual sample size varied between 6.0 to 20.4 $\mathrm{m}^{2}$ and each sample was composed either by three rows for soybean and maize or 12 rows for rice. The minimum length of each sample was $4.5 \mathrm{~m}$ and the number of samples per crop in a season was on average 14, attaining to 40 samples in some years. The samples were individually threshed and the grain moisture evaluated in an automatic analyser. Grain yield was standardized to $13 \%$ moisture for all crops. Grain yields obtained in each crop and cropping season were compared to the regional benchmarks, by accessing the yield database record from 14 municipalities nearest to the LES, which represents around 4,300 farms, between 20 ha to more than 2,500 ha (IBGE, 2015).

The biomass of aerial parts of crops, cover crops, pastures and spontaneous vegetation 
was measured by collecting eight samples of all vegetative material on the soil surface, at the end of both winter and summer season. An individual sample area of $2.25 \mathrm{~m}^{2}$ was used. Seed production from cover crops and spontaneous vegetation was assessed by collecting shattered seeds, using 15 units $\mathrm{ha}^{-1}$ of $12-\mathrm{cm}$ diameter dishes, randomly distributed in each cropping system. Biomass and seeds were dried at $60^{\circ} \mathrm{C}$ for 2 days before weighing. Root biomass was estimated as $20 \%$ of total dry mass (Poorter et al., 2012).

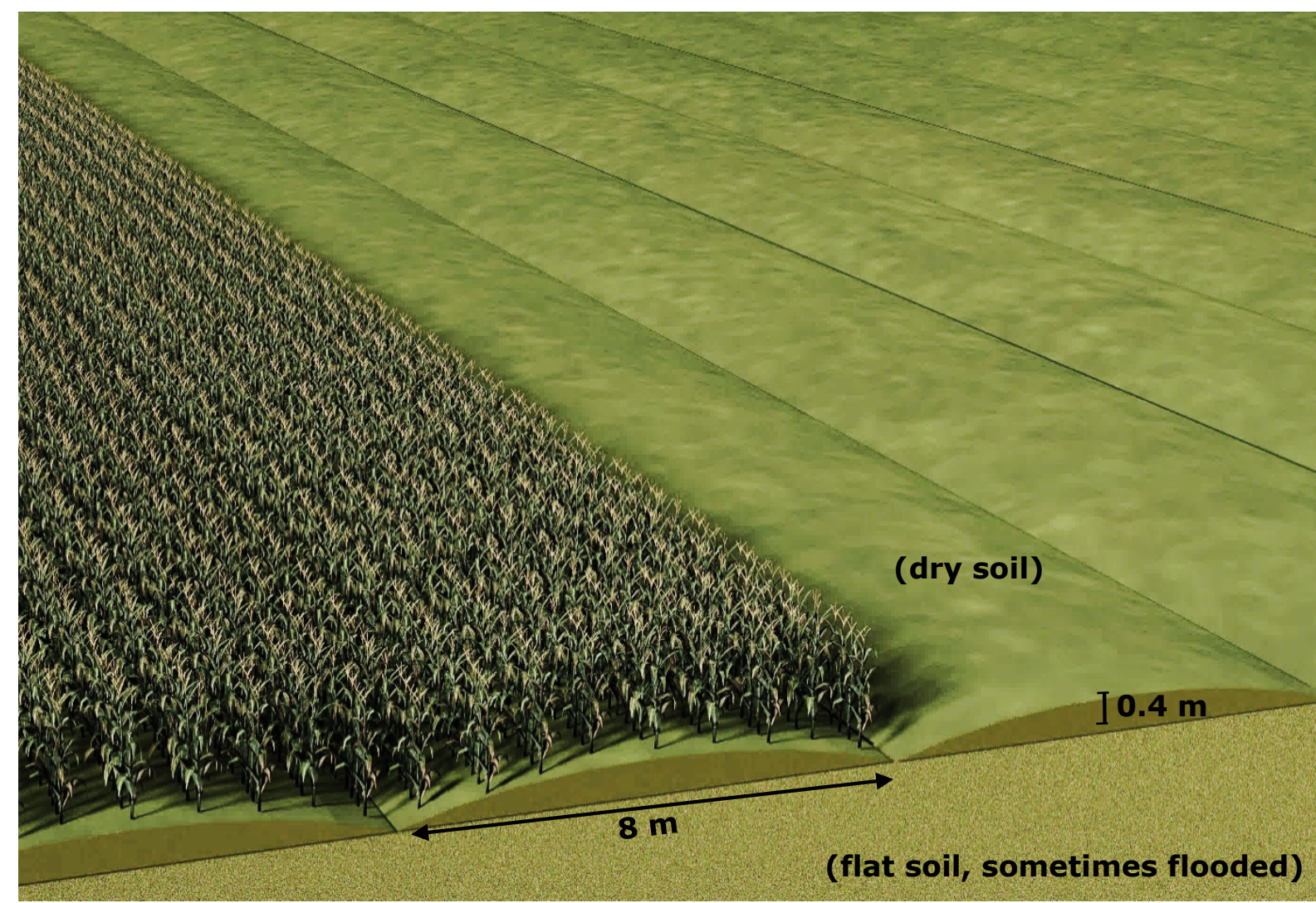

Figure 1. Simplified drawing of a ridge-based field. In the ridges, the dry soil allows no-tillage and cultivation of species not tolerant to flooding or excessive soil moisture, like maize. Drawing made by the author using the software Blender 3D v2.78.

Cattle production (gains in live weight) was evaluated by weighing each livestock unit on the days of entry and exit from the fields. The herd was composed of 1.5 to 2-year-old steers and heifers of Charolaise breed. Cattle remained in the experimental fields for a limited period of time each year (on average $81 \pm 4$ days).

\section{Field operations}

All field procedures and machinery used were equivalent to that used in commercial farms. The 
data collection registered all operations performed in the fields during the 9-year timespan of the experiment. Collected information was: a) the time to achieve each field operation; b) the fuel consumption, measured by filling the fuel tanks before and after each operation and recording the difference in volume; c) the electricity consumption for pumping water to the rice fields, measured as the difference registered in the electric meter of the pump at the start and the end of the cropping season; d) the time the water pump was running; e) the weight of all equipment, with the weight of tires and tubes separately considered to calculate the embodied energy of machinery; f) the amount and type of seeds, nutrients and pesticides used.

Description of the machinery, their weight, operational yield, average fuel consumption, embodied energy and total energy consumption is presented in the Supplementary Information section (item D). Embodied energy of machinery and the energetic depreciation in time was calculated using procedures described by Bowers (1992), Pimentel (1992) and Mantoam et al. (2016).

To estimate the energy consumption related to labour (farming work) the recorded time devoted for field operations was used as a basis. Additionally, 30 minutes extra for seeding and harvesting, and 15 minutes extra for soil operations, pesticide application, spreading nutrients and seeds were added, to account for loading and cleaning the machinery after use. Also, 25 minutes and $1 \mathrm{~L}$ of diesel were added to each field operation, to cover the inner-farm distance between the LES machinery shelter and the fields $(5.2 \mathrm{~km})$. The time for managing the cattle and the time for maintenance of channels and levees in rice fields were also recorded and included in the calculations.

Water for rice irrigation was provided by a pumping station with a centrifugal horizontal pump running a 100-CV three-phase electric motor located in a lake at approximately $1.5 \mathrm{~km}$ from the experimental area. The experimental farms were located at $16 \mathrm{~km}$ from the commercial point of acquisition of supplies and delivery of grains and cattle. To assess the transporting costs, the weight of main inputs (fertilizers, diesel fuel, seeds and pesticides) and outputs (grains and cattle) were considered. Distance from the farms to the market point was multiplied by 2 , to account for the return journeys. Data from a truck of $20,000 \mathrm{~kg}$ load capacity yielding 2.75 $\mathrm{km} \mathrm{L}^{-1}$ of diesel was used. The average time in transport of goods was 1.75 hours for acquiring inputs and 2.0 hours for delivering grains and cattle.

The energy equivalent contained in inputs (fertilizers, fuels, pesticides and seeds), grains (maize, rice and soybean), biomass and livestock are described in the Supplementary 
Information section (item E).

\section{Data adjustment in the Rice-Fallow cropping system}

The Rice-Fallow cropping system completed 1.5 full cycles in the timespan of 9-years of this study. The missing part of the $2^{\text {nd }}$ cycle corresponds to the period in which the system would be on rice production. For some indicators, this imbalance would result in biased, incorrect results. To correct for this, we included additional seasons for this cropping system through simulation. The new data, simulating three additional cropping seasons, were estimated using the Bayesian Monte Carlo method. Using the WinBugs software (Lunn et al., 2000), we generated a new set of data composed by the yield predictions for 2016, 2017 and 2018, based on a squared-regression of yearly rice yield from the 12 municipalities near LES between 2000 to 2015 . These data were combined by the Bayesian technique (30,000 iterations) with rice grain yields obtained in the Rice-Fallow system in 2010, 2011 and 2012, and a new set of simulated data was generated. For input data (fertilizers, pesticides and fuels), the amount used in the previous rice growing period was increased with $2 \%$, to follow the regional trend. All comparisons evolving from these adjusted data, or the indicators derived from it, were normalised on a yearly basis.

\section{Data analysis}

Analysis was performed in two main parts logically arranged: the first step consisted of a description of cropping systems up to the processes level. The second step corresponded to the creation of indicators and performance rankings.

The cropping systems were described according to primary production, labour requirement, energy use, input demand and financial results. The primary production included grains (maize, rice and soybean), gains in cattle live weight and other vegetative biomasses. Labour requirement (in $\mathrm{h} \mathrm{ha}^{-1} \mathrm{yr}^{-1}$ ) and energy use (in GJ ha ${ }^{-1} \mathrm{yr}^{-1}$ ) were each separated according to the main farm processes: soil preparation, plant nutrition, seeding, irrigation, pest management, harvest, transport and cattle management. A detailed description of energy consumed according to the source and destination was performed for each cropping system (energy expended in fuels, labour and machinery for each farm process, and energy content of fertilizers (separately for $\mathrm{N}, \mathrm{P}$ and $\mathrm{K}$ ), pesticides (separately for herbicides, fungicides, insecticides and adjuvants) and seeds).

For pesticides, data about active ingredient used per area in a year $\left(\mathrm{g} \mathrm{ha}^{-1} \mathrm{yr}^{-1}\right)$ was 
complemented with two additional indicators. The Biocide Residue Index (BRI) and the pesticide leaching potential to groundwater (PLPG). Both indicators provide an estimate about the potential environmental impact of pesticides. Whilst BRI has a profile associated to toxicology, PLPG is more related to water pollution. For BRI, the formula is [BRI = (chemical used $\left(\mathrm{g}\right.$ a.i. $\left.\mathrm{ha}^{-1}\right) \mathrm{x}$ toxicity index $\mathrm{x}$ persistence index $) / 100$ ], where the values for toxicity index are 10, 5, 2, and 1, based on the toxicity classes for pesticides of the Food and Agriculture Organization (FAO) (classes I, II, III, and IV, respectively). The persistence index is based on the pesticide half-life in soil, and three classes are considered: low (half-life $<30 \mathrm{~d}$ ), medium (half-life 30-100 d), and high (half-life $>100 \mathrm{~d}$ ) with indices of 1, 2.5, and 5, respectively. BRI values of $<100$ can be designated as 'safe', values between 100 and 200 are 'permissible', and a BRI of $>200$ is 'unsafe' (Pathak et al., 2011).

The pesticide leaching potential to groundwater (PLPG) was calculated using the model SCI-GROW (Screening Concentration in Ground Water) v.2.3 (US Environmental Protection Agency - EPA, 2017). The model estimates an exposure value associated to the potential risk to the environment and to human health from drinking water contaminated with the pesticide. It is based on the application rate and the environmental fate of the pesticide, provided by the aerobic soil degradation (half-life) and soil adsorption coefficient $\mathrm{K}_{\mathrm{oc}}$ (Estes et al., 2016). BRI and PLPG were calculated separately for each application of herbicide, insecticide, fungicide or seed treatment. The result here presented is the accumulated value, on a yearly-basis.

Financial costs, including variable and opportunity costs, financial balance and profitability were calculated on a yearly-basis for each cropping system. Prices used for inputs and outputs were based on the price encountered at the local market, in each respective cropping season. As the inputs and outputs were bought and/or sold at distinct moments, temporary differences in prices could bias the results. To avoid such disparities, average prices were used in the calculations. Opportunity costs of land were similar to prices used in the local market, valued at an equivalent $500 \mathrm{~kg}$ and $1000 \mathrm{~kg}$ of grains of rice per hectare per year, for rainfed crops and irrigated rice, respectively. For rice, variable costs were still increased by $6.5 \%$ to account for expenses related to drying of grains (IRGA, 2014). An additional 30\% over the variable costs of grain crops, and $15 \%$ for other land uses, were added to the yearly costs, in account of expenses related to taxes, depreciation, opportunity cost of investments, interest rates and insurances. 


\section{Indicators and KPIs arrangement}

The second step in this analysis evolved the set-up of indicators and KPI rankings. Three composite indicators associated to pesticides and grain production $(\mathrm{a}, \mathrm{b}, \mathrm{c})$, and six indicators associated to resource use-efficiency ( $\mathrm{d}, \mathrm{e}, \mathrm{f}, \mathrm{g}, \mathrm{h}, \mathrm{i})$ were initially generated:
a. active ingredient based-indicator (g a.i. applied per ton of grains produced)
b. Biocide Residue Index-based indicator (BRI per ton of grains produced)
c. leaching potential-based indicator (ppb pesticide leached per ton of grains produced)
d. labour efficiency ( $\mathrm{kg}$ food produced per hour of field labour)
e. labour profitability (monetary return per hour of field labour)
f. economic efficiency (net monetary return by unit of money invested)
g. fuel use-efficiency (MJ food produced per MJ diesel fuel used)
h. overall energy use-efficiency (MJ food produced per the overall energy used)
i. nitrogen use-efficiency for grain production (MJ grains produced per MJ N applied)

Additionally, for the pesticide related indicators (a, b, c) data was also presented per crop. In addition to the aforementioned indicators (a-i), the following records were also included in the posterior analysis: $\mathrm{j}$ ) total $\mathrm{N}$ applied, which is associated to the potential of nitrate leaching $\left.\left(\mathrm{kg} \mathrm{ha}^{-1} \mathrm{yr}^{-1}\right) ; \mathrm{k}\right)$ total amount of pesticides (active ingredient) applied ( $\mathrm{g} \mathrm{ha}^{-1}$ $\left.\mathrm{yr}^{-1}\right)$; 1) total field toxicology from pesticides (BRI ha-1 $\left.\left.\mathrm{yr}^{-1}\right) ; \mathrm{m}\right)$ total potential leaching of pesticides $\left.\left(\mathrm{ppb} \mathrm{ha}^{-1} \mathrm{yr}^{-1}\right) ; \mathrm{n}\right)$ land required to produce $1 \mathrm{~kg}$ of dry biomass $\left(\mathrm{m}^{2} \mathrm{~kg}^{-1}\right)$; o) total amount of food (grains + cattle weight gains) produced $\left(\mathrm{kg} \mathrm{ha}^{-1} \mathrm{yr}^{-1}\right) ; \mathrm{p}$ ) yearly financial balance (in Brazilian Reals, $\left.\mathrm{R} \$ \mathrm{ha}^{-1} \mathrm{yr}^{-1}\right)$; q) monetary risk (costs, in $\left.\mathrm{R} \$ \mathrm{ha}^{-1} \mathrm{yr}^{-1}\right)$; r) labour demand (h $\mathrm{ha}^{-1} \mathrm{yr}^{-1}$ ); s) gross $\mathrm{CO}_{2}$-e units sequestered from the atmosphere into biomass (assuming carbon constitutes $45 \%$ of the dry mass for crops used (Aita \& Giacomini, 2003; Niu et al., 2016), $\mathrm{kg}$ $\left.\mathrm{ha}^{-1} \mathrm{yr}^{-1}\right)$; t) $\mathrm{CO}_{2}$-e units $\left(\mathrm{kg} \mathrm{ha}^{-1} \mathrm{yr}^{-1}\right)$ emitted to atmosphere as a result of fuel combustion, assuming $3.368 \mathrm{~kg} \mathrm{CO}_{2}-\mathrm{e} \mathrm{L}^{-1}$ diesel (2.966 $\mathrm{kg} \mathrm{CO}_{2}$-e from combustion (IPCC, 2006) + 0.320 $\mathrm{kg} \mathrm{CO}$-e from production (Carvalho, 2012) $+0.082 \mathrm{~kg} \mathrm{CO}_{2}$-e from transports (Eriksson \& Ahlgren, 2013)); and u) the differences between the grains produced in each cropping system and the regional benchmarks $\left(\mathrm{kg} \mathrm{ha}^{-1} \mathrm{yr}^{-1}\right)$.

All indicators were standardized on a 0 to 1 scale. For those indicators for which a high value is preferable (hereafter named "Type 1": $d, e, f, g, h, i, o, s, u$ ), the highest value recorded received a score of 1 , and lower values were attributed to the other records in a proportional way, using the formula $X_{n i}=\frac{x_{i}}{\operatorname{Max}(x)_{i}}$. If for an indicator the value for one of cropping systems 
resulted in a negative score, this lowest negative value received a score of zero, whereas the highest value received a score of 1 . Inversely, for those indicators for which a low value is preferable ("Type 2": a, b, c, j, k, 1, m, n, p, q, r, t) the highest value recorded received a score of 0 , and higher values were attributed to the other records using the formula $X_{n i}=1-$ $\left(\frac{x_{i}}{\operatorname{Max}(x)_{i}}\right)$. For both cases, $X_{n i}$ is the standardized value of cropping system $n$ for the indicator $i$; $x_{i}$ is the current record; and $\operatorname{Max}(x)_{i}$ is the highest value found for indicator $i$, across all cropping systems.

After standardization, the indicators $\mathrm{a}, \mathrm{b}$ and $\mathrm{c}$ (intensity of pesticides and its impact expressed per unit of grain produced) and $\mathrm{k}, 1$ and $\mathrm{m}$ (active ingredient, toxicology and leaching potential of pesticides per unit of land) were averaged and combined into two new indicators. These two new composite indicators were used, instead of the original six, to avoid an overrepresentation of pesticides in the KPI associated to environment.

Each standardized indicator was associated to one of the five Key-Performance Indicators (KPI): 1. Environment ((a,b,c), $(\mathrm{k}, 1, \mathrm{~m}), \mathrm{j}, \mathrm{s}, \mathrm{t}) ; 2$. Primary land production $(\mathrm{n}, \mathrm{o}, \mathrm{u})$; 3. Economics (f, p, q); 4. Energy use-efficiency (g, h, i); and 5. Labour (d, e, r). For each KPI the standardized values of the underlying indicators were added for each cropping system separately. These five values were then added to obtain a common denominator. Accordingly, each five individual totals were divided by the common denominator and multiplied by a factor of 5. This value indicates the relative performance of a specific cropping system for this KPI, whereby a value of 1 represents an average performance, values smaller than 1 represent underperformance and values larger than 1 represent a superior performance. For each cropping system, scores for all five KPI's were summarized in a radar plot graph for visual analysis. A general overview of the experimental framework is depicted in Figure 2.

\section{Statistical analysis}

Data were tested for normality assumption by using the Shapiro-Wilk test, provided by the Proc Univariate in SAS software version 9.4 (SAS Institute, 2016). Variables normally distributed followed analysis of variance, using mixed models (Proc Mixed, in SAS software). Cropping systems was assumed as the fixed factor, with cropping seasons as the random factor. Treatments were compared by using the least squares means difference (LSMeans, with option PDIFF in SAS software). Variables with non-normally distributed data were square-root transformed. If rooted values still presented a non-normal distribution, data were submitted to 
Kruskal-Wallis test, using the Proc NPAR1WAY in SAS software. Post-hoc Dunn-Bonferroni test was then applied to distinguish cropping systems, using the Nonparametric Tests module in SPSS software version 23. For these cases, medians and the interquartile range [0.25-0.75] are presented, instead of means and standard errors. Data are presented as yearly means and their corresponding SEM, except if indicated otherwise.

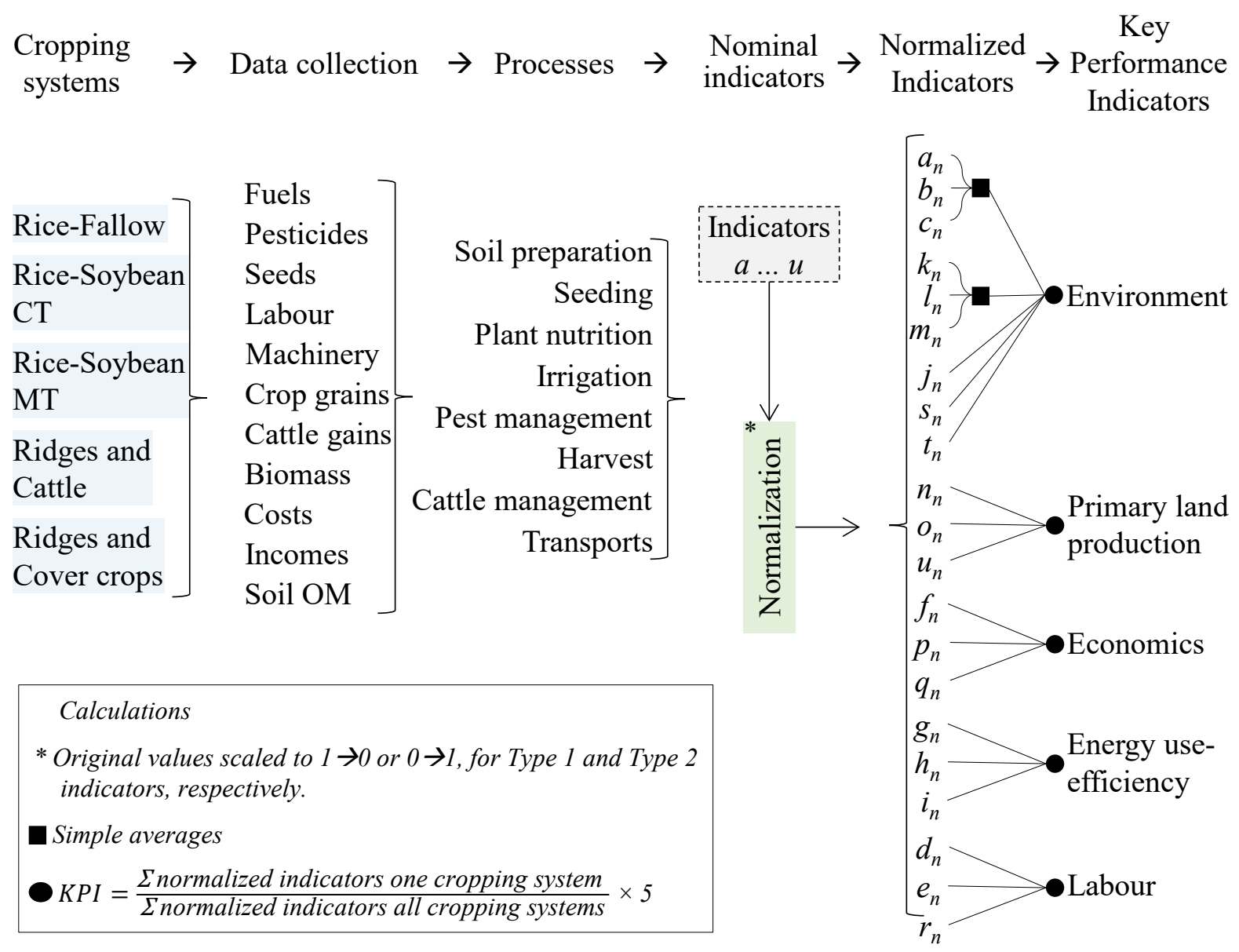

Figure 2. Overview of experimental setup, data collection and composition of Processes and Key Performance Indicators used to evaluate five cropping systems in the lowlands of South Brazil.

\subsection{Results}

\section{a) Primary land production}

The three main components of land production (grains, other biomass and gains in cattle weight) were separately analysed. Average crop production varied between 3.7 and $5.2 \mathrm{Mg}$ of grains per hectare a year (Figure 3). An apparent advantage of $1.1 \mathrm{Mg}$ was recorded for the 
average production of Rice-Soybean CT, Rice-Soybean MT and Ridges and Cattle, over the Rice-Fallow and Ridges and Cover crops. Despite these differences, the large overlapping of standard errors suggests that these values are probably not significantly different. Estimating the area needed to produce one unit of grains (the inverse of $\mathrm{kg} \mathrm{ha}^{-1}$ ) provides the differences between these systems in terms of land use efficiency. Rice and Fallow, the oldest system, required $2.74( \pm 0.82) \mathrm{m}^{2}$ to produce $1 \mathrm{~kg}$ of grains, whilst the other systems used between 1.92 $( \pm 0.37)$ to $2.40( \pm 0.36) \mathrm{m}^{2}$. These data suggest that part of the land could be saved from cultivation (from 14 to $42 \%$ according our data) if a farmer substitutes Rice-Fallow for one of the other cropping systems without fallow.

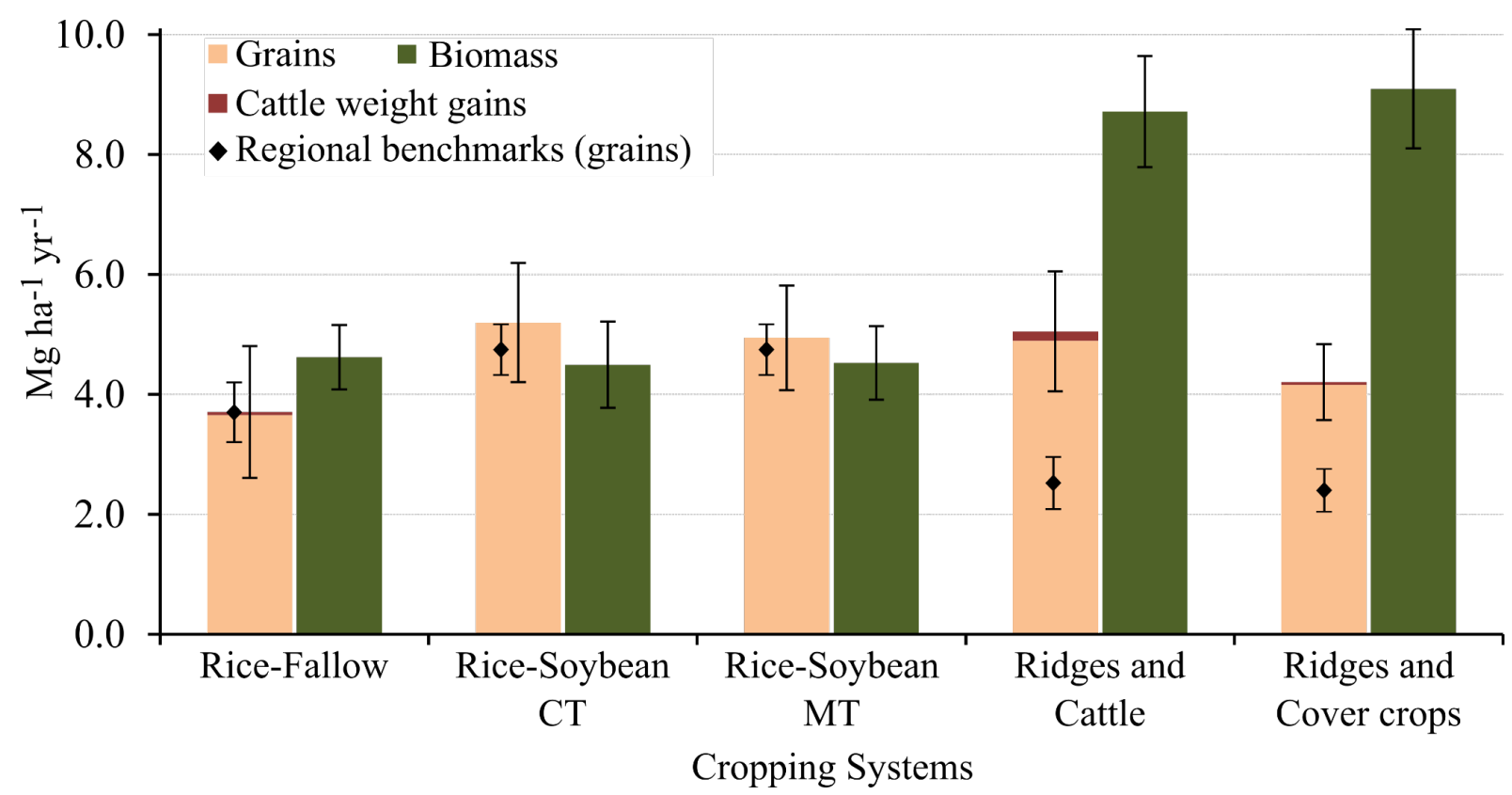

Figure 3. Productivity of grains (maize, rice and soybean), other biomass, and gains in cattle live weight $\left(\mathrm{Mg} \mathrm{ha}^{-1} \mathrm{yr}^{-1}\right)$ in five cropping systems established in an experimental station in the lowlands of south Brazil. Regional benchmarks for grain yield are provided. Error bars indicate standard error of the mean.

The regional benchmarks (Figure 3) encompass the average yields of soybean, rice and maize from 14 municipalities near to the experimental station, in the timeframe 2006 to 2015 . Compared to this reference, rice in Rice-Fallow system was on average around 3\% less productive. Despite minimal, that distinction found an explanation since part of the farmers use crop rotation (rice-soybean), which benefits rice yields in the long run. Such benefit from soybean was not embedded in the monocrop-based Rice-Fallow. Rice-soybean systems yielded around 5\% more than the regional benchmark, and a large differential was found for the ridge- 
based systems, which produced around $80 \%$ more than the regional references. This distinction is explained by the favourable conditions provided by the ridges, allowing maize and soybean to express a much higher yield potential than what can be realized in the flat soils in the lowland. The differences between grain productivity in the cropping systems and the regional benchmarks are an estimator of land use efficiency, and were associated to the KPI 'primary land production'.

Cattle production was marginal if compared to grain production. Measured values of live weight gains were 50 and $152 \mathrm{~kg} \mathrm{ha}^{-1} \mathrm{yr}^{-1}$ (Figure 3), with daily gains of 0.60 and $0.90 \mathrm{~kg}$ head day $^{-1}$ for cropping systems Rice-Fallow and Ridges and Cattle, respectively. Cattle production per area is well below the values observed for grains, scaled in thousands of $\mathrm{kg}$ per hectare, however, recorded cattle performance was similar to what was found in other croplivestock systems in south Brazil (Sório Jr., 2001; Balbinot Junior et al., 2009).

Large differences between the cropping systems were observed for biomass production. Non-food biomass, e.g. cover crops, pastures and crop residues after harvest, attained $8.9 \mathrm{Mg}$ $\mathrm{ha}^{-1} \mathrm{yr}^{-1}$ for the cropping systems conducted on ridges. The three rice-based systems produced around $4.5 \mathrm{Mg}$ per hectare (Figure 3), most of it represented by crop residues after harvest. Analysing the biomass production over the optics of land productivity, the differences are still more emphatic: systems conducted on ridges required, on average, $1.39 \pm 0.23 \mathrm{~m}^{2}$ to produce 1 $\mathrm{kg}$ of dry biomass. To produce a similar amount, the rice-based systems required almost two times this area $\left(2.73 \pm 0.25 \mathrm{~m}^{2}\right)$.

A high biomass production is an important factor associated to cropping system efficiency, particularly if considering the potential of the system to reduce greenhouse gas emissions (GHG) and global warming. Assuming carbon (C) constitutes 45\% of dry biomass for the species used in this study, the differences between the rice-based systems to the ridgebased systems on biomass production was equivalent to a fixation of 7.2 ton of carbon dioxide $\left(\mathrm{CO}_{2}\right)$, which was assimilated into the plants (calculated from Figure 3 data, using 44/12 as the conversion factor $\mathrm{C} \rightarrow \mathrm{CO}_{2}$ ). Part of this carbon was effectively incorporated into soil organic matter (SOM), since after nine years of rotation the systems conducted on ridges had increased SOM by $48 \%$ (from $1.5 \%$ to $2.2 \%$ ). The increase in SOM in rice-based systems in the same period was on average $10 \%$.

\section{b) Labour}

Although in most crop production processes the physical effort is alleviated by mechanization 
and automation, a certain amount of personal work on field activities is still required. As labour (availability, profitability and quality) is one important issue for cropping systems in south Brazil (Froehlich et al., 2011) and affects social perspectives even outside of farms, Labour was included as one of the Key Performance Indicators in the current analysis.

Cropping systems were quite distinct regarding field labour requirement. The number of hours spent on field processes varied between 16 to $61 \mathrm{~h} \mathrm{yr}^{-1}$ (Figure 4). On average, the systems conducted on ridges required less labour compared to the rice-based systems. Cropping systems with rice need most of the field labour in the processes related to irrigation. The maintenance and monitoring of pumps, water channels, bunds and levees during the rice cycle are the most demanding labour component in irrigated rice production. On average, $41.2 \mathrm{~h} \mathrm{ha}^{-1}$ per year was dedicated to these functions. We highlight, however, that these values are the annual means from cropping systems in which rice was cultivated in half of the seasons. The absolute number of hours dedicated to irrigation-related activities in a rice season was approximately twice $(82.2 \pm 3.1)$ the yearly-averaged values presented in Figure 4 .

The labour required for other farming processes differed between the cropping systems. Soil preparation (plough, harrowing and planning) was, in general, an important demand for rice-based systems, especially for the rice-soybean rotation conducted in conventional tillage (Figure 4). Labour time required for pest management was an important requirement for all systems, especially for the cropping systems based on minimum- and no-tillage (Rice-Soybean MT, Ridges and Cattle, Ridges and Cover crops). Except for the Rice-Fallow system, processes like plant nutrition, seeding and harvesting were relatively uniform in terms of labour demand between the cropping systems. In the systems in which grain production was integrated with cattle production, the time used on cattle management was relatively low, with on average $6.9 \%$ of the overall labour time. Transport was the process with the smallest demand (1.9\%).

The time used for administrative tasks was not measured in the current work. It is valid to mention, however, that administrative farm activities demand 21 hours per hectare per year, for a typical lowland farm, according to surveys reported by the RS State Rice Institute (IRGA, 2014). 


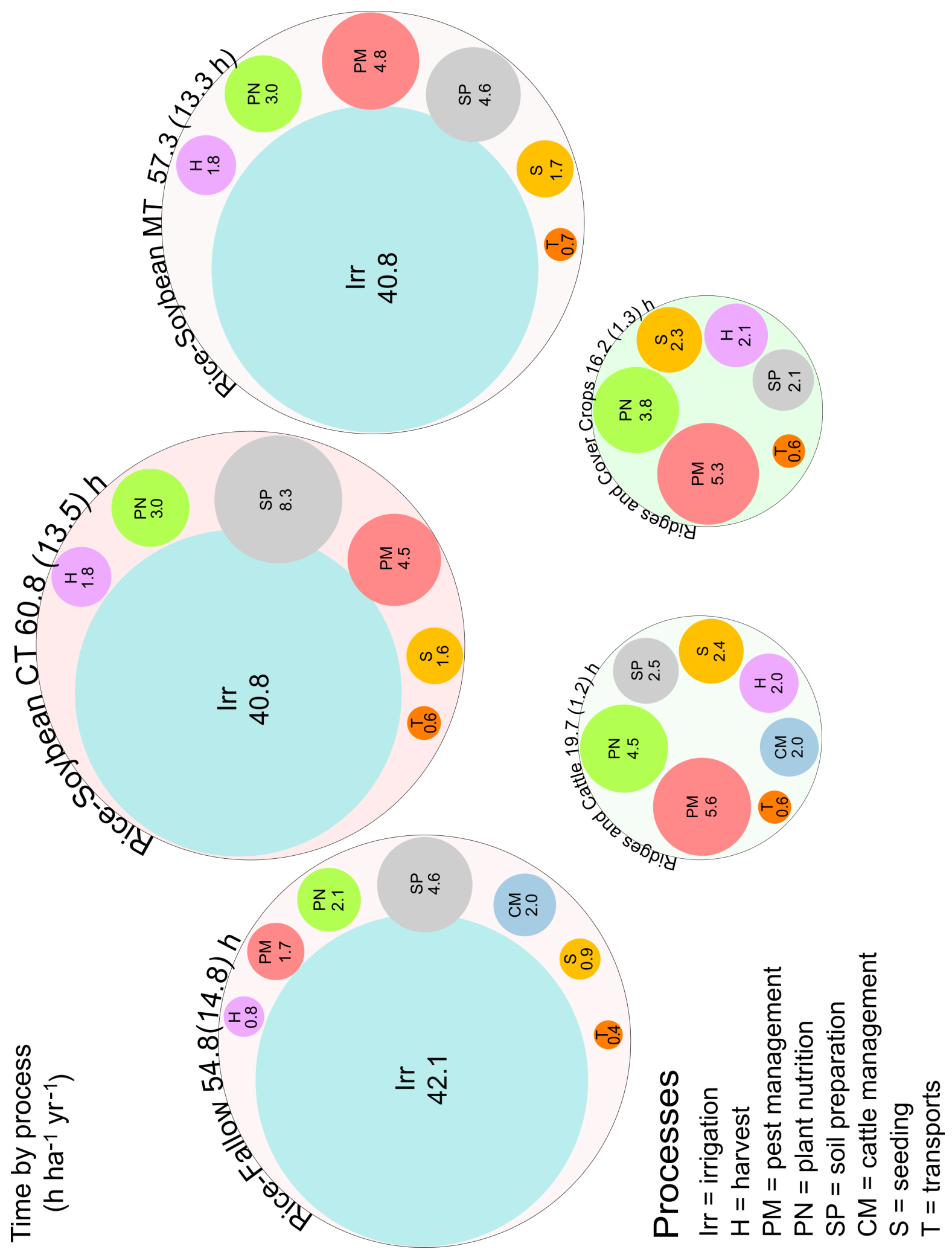

Figure 4. Average annual time of labour $\left(\mathrm{h} \mathrm{ha}^{-1} \mathrm{yr}^{-1}\right)$ on farming processes in five cropping systems in the lowlands of south Brazil. Area of the circles reflects average labour time spend on each process, or the accumulated labour time within a cropping system (large circle). Values between parentheses are the standard errors of the mean. 


\section{c) Energy demand of field processes}

The cropping systems required between 15 and 22 GJ of energy per hectare per year (Figure 5). These values are in the range of previous reports for rotation-based, mixed cropping systems (Alipour et al., 2012; Sá et al., 2013). Rice-Fallow consumed the smallest amount of energy. This was expected since the cultivation of rice, the most demanding activity, was only present in the field for half of the cropping seasons. Rice-soybean rotation required around $45 \%$ more energy than the traditional rice-fallow. The ridge-based systems were even more economical, consuming $11 \%$ less energy than the rice-soybean rotations.

Plant nutrition, which included the energy content of fertilizers, fuels, energy embodied in machinery used for fertilizer application, and energy for labour, was the most important process in terms of energy demand across all cropping systems. Plant nutrition represented 34\% of all energy used in the rice-based systems, and covered $49 \%$ for the ridge-based systems. The activities related to irrigation represented the second most important sink of energy in systems with irrigated rice, while processes related to seeding consumed around $20 \%$ of the yearly energy budgets. Embodied energy in seeding material (e.g. seed processing, chemical treatments, packaging and transport) is an important aspect in this regard. In fact, the seeds themselves represented between 13.8 to $20.6 \%$ of all energy demanded by the cropping systems (Table 1).

The energy required for transport and cattle management was grouped, and still it was very low in comparison to other farming processes (Figure 5). For instance, transports and cattle management used between 1/20 and 1/53 of the energy used for plant nutrition, in Rice-Fallow and Ridges and Cover crops, respectively. Considering the average of all cropping systems, transports and cattle management consumed just $1 \%$ of the overall energy budget. The energy required for soil preparation was clearly distinct between the rice-soybean systems. In conventional-tillage, soil preparation required $3.5 \mathrm{GJ} \mathrm{ha}^{-1} \mathrm{yr}^{-1}$, equivalent to a $96 \%$ increase in relation to minimum-tillage (Figure 5). Most of this difference is attributed to the fuels. In fact, Rice-Soybean CT consumed $35 \mathrm{~L}^{\text {diesel }} \mathrm{ha}^{-1}$ more than Rice-Soybean MT in a single year (Table 1). 


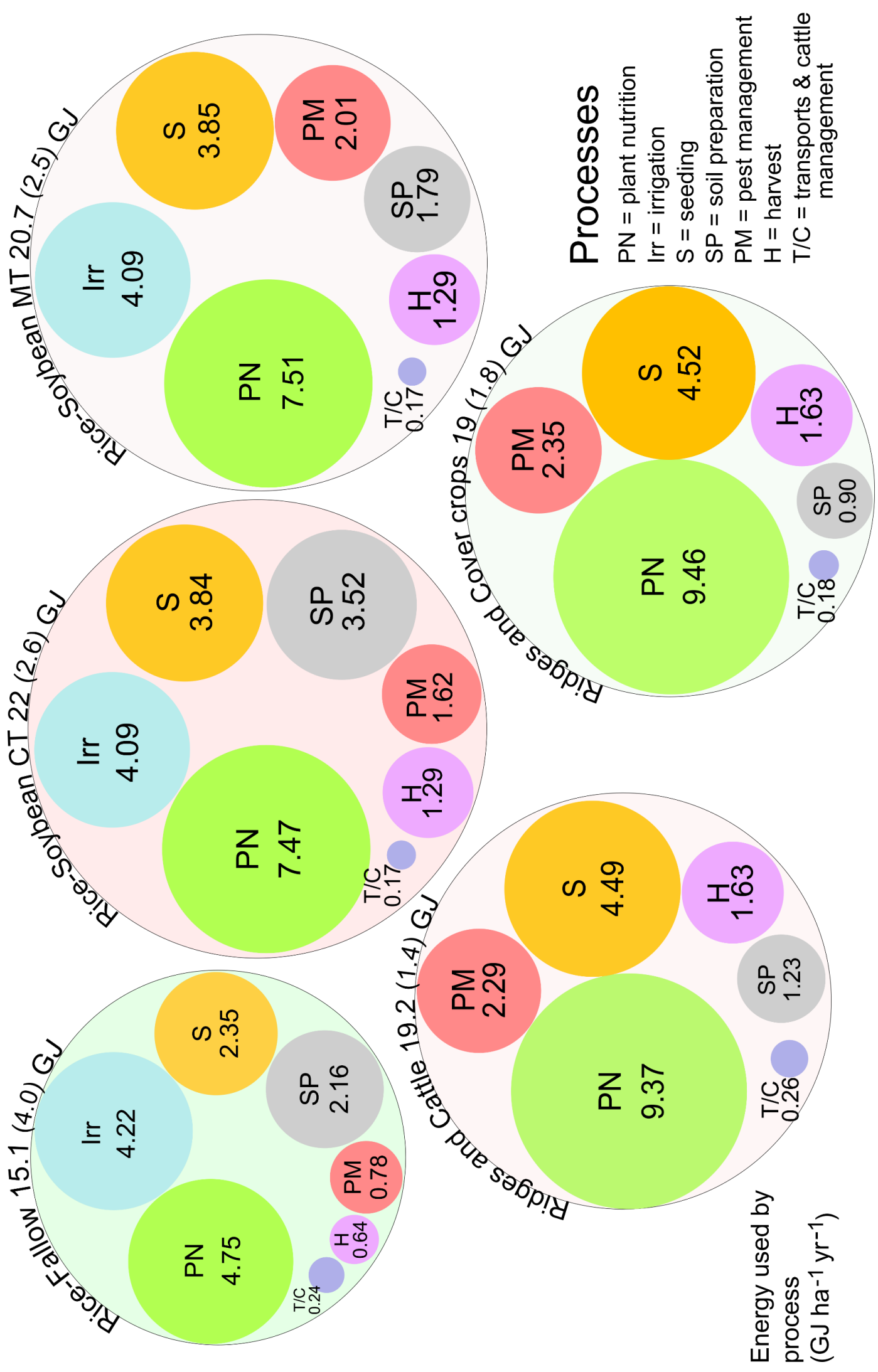

Figure 5. Average annual amount of energy used (GJ ha-1 $\left.\mathrm{yr}^{-1}\right)$ on farming processes in five cropping systems in the lowlands of south Brazil. Area of the circles reflects the average energy per process, or the accumulated energy within a cropping system (large circle). Values between parentheses are the standard errors of the mean. 
In the ridge-based systems soil preparation was a low sink of energy if compared to plant nutrition, seeding or pest management. On average, soil-related activities consumed only $5.5 \%$ of annual energy budgets for these systems, which is considerably smaller than the 9 to $16 \%$ range found for the rice-based systems (Figure 5). Most of the energy spent as soil preparation was registered at the moment of construction of ridges, in 2006. Conversely, the ridge-based systems were the cropping systems with the larger proportion of energy (as well as time of labour) used for pest management (PM). Around 12\% of all energy in these cropping systems was directed to PM, contrasted to $7 \%$ for the rice-based systems.

\section{d) Energy demand by input type}

To get a better understanding of the cropping systems, the energy use was also assessed for each type of input (Table 1). Data are shown in standardized energy units, and original values (e.g. litres of diesel, $\mathrm{kg}$ of fertilizers, etc.) can be easily calculated using the conversion indexes listed in the Supplementary Information section (item E).

Fuels were the most important sink of energy for inputs used in the rice-based cropping systems, accounting for $48 \%$ of energy used in these systems. Irrigation ${ }^{2}$ and soil preparation were the most fuel-demanding activities. Fertilizers were the second most important energy sink for the rice-based systems, and the higher energy-demanding input for the ridge-based models. Nitrogen was clearly the most energy-expensive nutrient for all cropping systems, representing around $2 / 3$ of the energy consumption related to fertilizers.

Seeds were ranked as the third most expensive input in terms of energy consumption, and pesticides were the fourth. Herbicides were the most important component of pesticides, representing $83 \%$ of the energy of this group. In terms of energy use, the pesticide burden can be considered relatively low. Less than 5\% [1.7\% - 4.4\%] of all energy used was represented by pesticides. The environmental impact from these compounds, however, is an important aspect and will be discussed later in this article.

\footnotetext{
${ }^{2}$ The energy used in electrical irrigation pump was converted to diesel-equivalent units, and included as Fuel in the input types (Table 1).
} 
Table 1. Energy used ( $\left.\mathrm{MJ} \mathrm{ha}^{-1} \mathrm{yr}^{-1}\right)$ by type of input in five cropping systems established on an experimental station in the lowlands in south Brazil. Averaged values for 12 (Rice-Fallow) and 9 (other systems) cropping seasons.

\begin{tabular}{|c|c|c|c|c|c|c|c|c|c|c|}
\hline \multirow{3}{*}{ Input type } & \multicolumn{10}{|c|}{ Cropping systems } \\
\hline & \multicolumn{2}{|c|}{ Rice-Fallow } & \multicolumn{2}{|c|}{$\begin{array}{c}\text { Rice-Soybean } \\
\text { CT }\end{array}$} & \multicolumn{2}{|c|}{$\begin{array}{c}\text { Rice-Soybean } \\
\text { MT }\end{array}$} & \multicolumn{2}{|c|}{$\begin{array}{l}\text { Ridges and } \\
\text { Cattle }\end{array}$} & \multicolumn{2}{|c|}{$\begin{array}{l}\text { Ridges and } \\
\text { Cover crops }\end{array}$} \\
\hline & Value & $\%$ & Value & $\%$ & Value & $\%$ & Value & $\%$ & Value & $\%$ \\
\hline \multicolumn{11}{|l|}{ Fuels } \\
\hline Irrigation & 3932 & 26.0 & 3812 & 17.3 & 3812 & 18.4 & 0 & 0 & 0 & 0 \\
\hline Soil preparation & 1956 & 12.9 & 3207 & 14.6 & 1642 & 7.9 & 1125 & 5.9 & 817 & 4.3 \\
\hline Plant nutrition & 424 & 2.8 & 622 & 2.8 & 655 & 3.2 & 960 & 5.0 & 956 & 5.0 \\
\hline Pest control & 419 & 2.8 & 1116 & 5.1 & 1209 & 5.9 & 1360 & 7.1 & 1302 & 6.9 \\
\hline Seeding & 224 & 1.5 & 357 & 1.6 & 375 & 1.8 & 673 & 3.5 & 532 & 2.8 \\
\hline Harvest & 588 & 3.9 & 1175 & 5.3 & 1175 & 5.7 & 1493 & 7.8 & 1493 & 7.9 \\
\hline Transports/Cattle m. & 236 & 1.6 & 174 & 0.79 & 166 & 0.80 & 259 & 1.3 & 176 & 0.93 \\
\hline Sub total & 7779 & 51.4 & 10463 & 47.6 & 9034 & 43.7 & 5870 & 30.5 & 5276 & 27.8 \\
\hline \multicolumn{11}{|l|}{ Fertilizers } \\
\hline $\mathrm{N}$ & 3081 & 20.4 & 4258 & 19.4 & 4258 & 20.6 & 5463 & 28.4 & 5514 & 29.1 \\
\hline$P$ & 666 & 4.4 & 1340 & 6.1 & 1340 & 6.5 & 1352 & 7.0 & 1509 & 8.0 \\
\hline $\mathrm{K}$ & 517 & 3.4 & 1155 & 5.3 & 1155 & 5.6 & 1461 & 7.6 & 1349 & 7.1 \\
\hline Sub total & 4264 & 28.2 & 6753 & 30.7 & 6753 & 32.7 & 8276 & 43.1 & 8372 & 44.1 \\
\hline Seeds & 2090 & 13.8 & 3423 & 15.6 & 3403 & 16.5 & 3705 & 19.3 & 3899 & 20.5 \\
\hline \multicolumn{11}{|l|}{ Pesticides } \\
\hline Herbicides & 233 & 1.5 & 262 & 1.2 & 513 & 2.5 & 592 & 3.1 & 696 & 3.7 \\
\hline Insecticides & 2.4 & 0.02 & 28 & 0.13 & 29 & 0.14 & 56 & 0.29 & 60 & 0.32 \\
\hline Fungicides & 20 & 0.13 & 36 & 0.16 & 36 & 0.17 & 22 & 0.11 & 22 & 0.12 \\
\hline Adjuvants & 37 & 0.24 & 57 & 0.26 & 73 & 0.35 & 48 & 0.25 & 59 & 0.31 \\
\hline Sub total & 292 & 1.9 & 383 & 1.7 & 651 & 3.2 & 718 & 3.7 & 837 & 4.4 \\
\hline \multicolumn{11}{|l|}{ Machinery } \\
\hline Irrigation & 230 & 1.5 & 223 & 1.0 & 223 & 1.1 & 0 & 0 & 0 & 0 \\
\hline Soil preparation & 191 & 1.3 & 299 & 1.4 & 142 & 0.69 & 100 & 0.52 & 78 & 0.41 \\
\hline Plant nutrition & 58 & 0.38 & 86 & 0.39 & 98 & 0.47 & 122 & 0.63 & 124 & 0.65 \\
\hline Pest control & 45 & 0.30 & 86 & 0.39 & 91 & 0.44 & 143 & 0.74 & 138 & 0.73 \\
\hline Seeding & 36 & 0.24 & 55 & 0.25 & 67 & 0.32 & 105 & 0.55 & 87 & 0.46 \\
\hline Harvest & 55 & 0.36 & 109 & 0.50 & 109 & 0.53 & 134 & 0.70 & 134 & 0.71 \\
\hline Sub total & 615 & 4.1 & 858 & 3.9 & 730 & 3.5 & 604 & 3.1 & 561 & 3.0 \\
\hline \multicolumn{11}{|l|}{ Labour } \\
\hline Irrigation & 91 & 0.44 & 88 & 0.29 & 88 & 0.30 & 0 & 0 & 0 & 0 \\
\hline Soil preparation & 10 & 0.07 & 18 & 0.08 & 9.9 & 0.05 & 5.4 & 0.03 & 4.1 & 0.02 \\
\hline Plant nutrition & 4.5 & 0.03 & 6.7 & 0.03 & 6.5 & 0.03 & 9.7 & 0.05 & 8 & 0.04 \\
\hline Pest control & 3.6 & 0.02 & 9.6 & 0.04 & 10 & 0.05 & 12 & 0.06 & 11 & 0.06 \\
\hline Seeding & 1.9 & 0.01 & 3.5 & 0.02 & 3.6 & 0.02 & 5.3 & 0.03 & 4.7 & 0.02 \\
\hline Harvest & 1.8 & 0.01 & 4 & 0.02 & 4 & 0.02 & 4.4 & 0.02 & 4.4 & 0.02 \\
\hline Transports/Cattle m. & 5.2 & 0.03 & 1.3 & 0.01 & 1.2 & 0.01 & 5.7 & 0.03 & 2.5 & 0.01 \\
\hline Sub total & 88 & 0.59 & 102.1 & 0.48 & 94.2 & 0.47 & 42.5 & 0.22 & 34.7 & 0.18 \\
\hline Total* $\left(\mathrm{MJ} \mathrm{ha}^{-1} \mathrm{yr}^{-1}\right)$ & $\begin{array}{l}15158 \\
(4003)\end{array}$ & & $\begin{array}{l}22011 \\
(2605)\end{array}$ & & $\begin{array}{l}20694 \\
(2496)\end{array}$ & & $\begin{array}{l}19216 \\
(1365)\end{array}$ & & $\begin{array}{l}18980 \\
(1815)\end{array}$ & \\
\hline
\end{tabular}

* Values between parentheses are the SEM. N=12 (Rice-Fallow); $\mathrm{N}=9$ (other cropping systems). 
Fuels were the most important sink of energy for inputs used in the rice-based cropping systems, accounting for $48 \%$ of energy used in these systems. Irrigation ${ }^{3}$ and soil preparation were the most fuel-demanding activities. Fertilizers were the second most important energy sink for the rice-based systems, and the higher energy-demanding input for the ridge-based models. Nitrogen was clearly the most energy-expensive nutrient for all cropping systems, representing around $2 / 3$ of the energy consumption related to fertilizers.

Seeds were ranked as the third most expensive input in terms of energy consumption, and pesticides were the fourth. Herbicides were the most important component of pesticides, representing $83 \%$ of the energy of this group. In terms of energy use, the pesticide burden can be considered relatively low. Less than $5 \%[1.7 \%-4.4 \%]$ of all energy used was represented by pesticides. The environmental impact from these compounds, however, is an important aspect and will be discussed later in this article.

Energy embodied in the machinery was also relatively small, if compared to the overall energy use in the cropping systems. With an average close to $670 \mathrm{MJ} \mathrm{ha}^{-1} \mathrm{yr}^{-1}$ across the systems, it represented around $3.5 \%$ of all the energy consumption. Another minor proportion is the energy required for human labour, which is commonly ignored in similar studies. Energy consumed by farming work represented less than $0.5 \%$ of the overall energy use in the evaluated systems. Compared to the energy required by fuels and machinery, the energy for human labour represented a portion of just 1/121. These low proportions and values for labour (Table 1) are similar to those previously reported for farming work in intensive cropping systems (Pimentel, 1992; Connor et al., 2011).

\section{e) Pesticide use and estimated impact}

Clear distinctions between cropping systems exists in terms of pesticide use (Figure 6). RiceFallow and Rice-Soybean CT consumed fewer pesticides than the other cropping systems, with average annual application rates of 700 and $910 \mathrm{~g}$ a.i. ha ${ }^{-1} \mathrm{yr}^{-1}$, respectively. The other systems (Rice-Soybean MT and the ridge-based systems) consumed almost two times more pesticides in the same time [1586 - $\left.2089 \mathrm{~g} \mathrm{ha}^{-1} \mathrm{yr}^{-1}\right]$. Herbicides are by far the most used class of pesticides, representing $85 \%$ of all active ingredients applied in the fields. An important difference between the rice-soybean rotations can be highlighted: while minimum-tillage saved around $35 \mathrm{~L}$ of diesel by minimizing soil preparation, the system was more dependent on

\footnotetext{
${ }^{3}$ The energy used in electrical irrigation pump was converted to diesel-equivalent units, and included as Fuel in the input types (Table 1).
} 
pesticides, using $672 \mathrm{~g} \mathrm{ha}^{-1}$ more herbicides than in the system with conventional soil preparation.

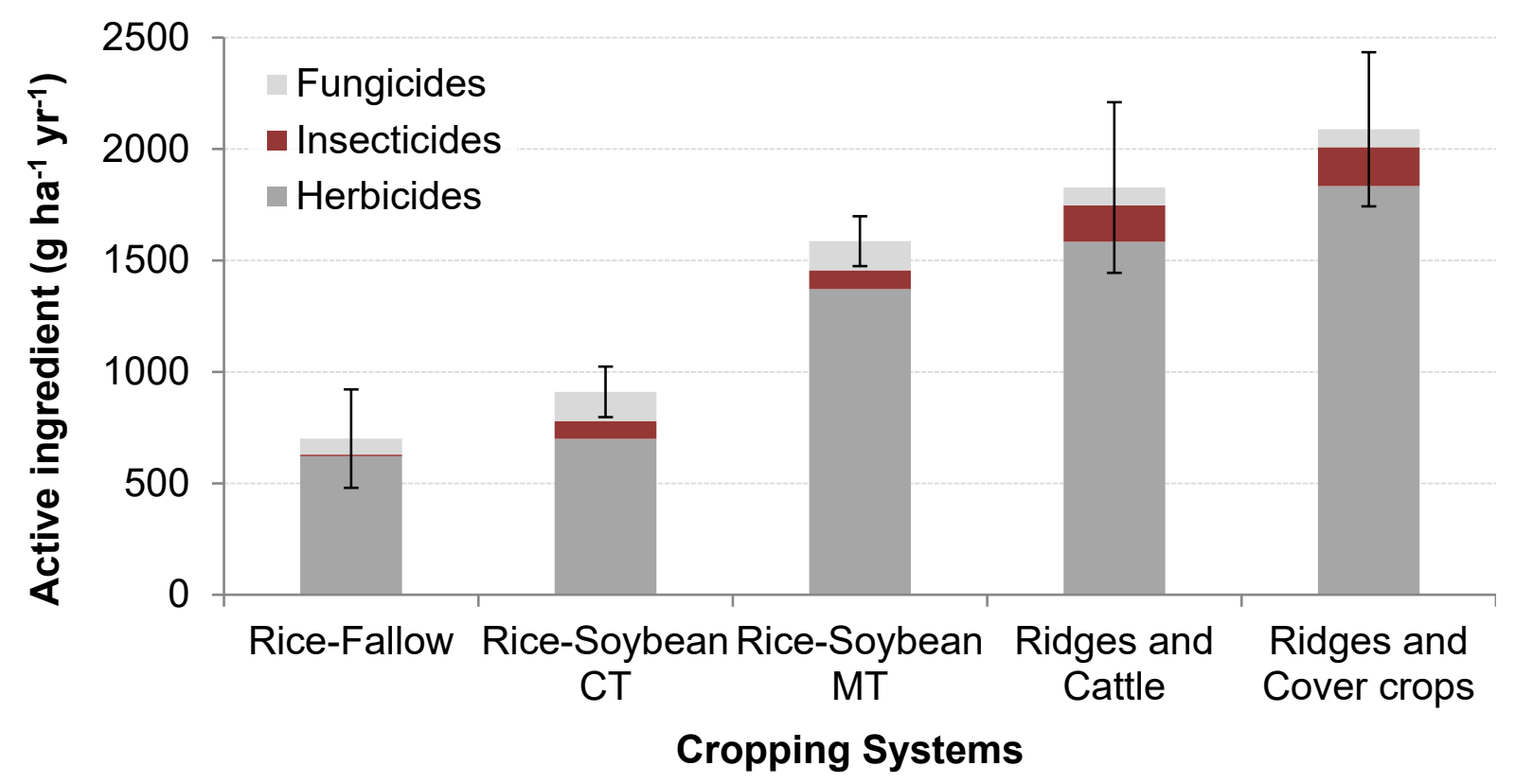

Figure 6. Average annual pesticide applied (g active ingredient $\mathrm{ha}^{-1} \mathrm{yr}^{-1}$ ) in five cropping systems installed on an experimental station in the lowlands of south Brazil. Error bars indicate standard errors of the mean for the total amount of pesticides.

Just as the use rates, the potential environmental effect of pesticides varied between cropping systems. The Biocide Residue Index (BRI) for Rice-Fallow was smaller than the values calculated to systems conducted in minimum-till or no-till (Figure 7). For the Pesticide Leaching Potential for Groundwater (PLPG), the Rice-Fallow system also presented a smaller absolute value, which was $60 \%$ less than the averaged PLPG of the other cropping systems.

The apparently small pesticide footprint from the Rice-Fallow system is not reflected when the pesticide-related indicators are weighed by the amount of grains produced. The smallest value found for the indicator based on a.i. applied per ton of grain produced ("a", in Table 2) was found in the Rice-Soybean CT system, for instance. The less suitable system from this optics was Ridges and Cover crops, with almost 590 grams of pesticides applied for one ton of grains produced. For the Rice-Soybean MT, the value was two times higher than the value calculated for conventional soil preparation. This difference, although not significant $(p=0.1)$, is agronomically important, and can be attributed mostly to the herbicides. Independent of cropping system, soybean was the crop with the more intensive use of pesticides per product, 
followed by maize and rice. For the production of one ton of maize and rice, just $50 \%$ and $24 \%$ of pesticides used to produce one ton of soybean, respectively, was required.

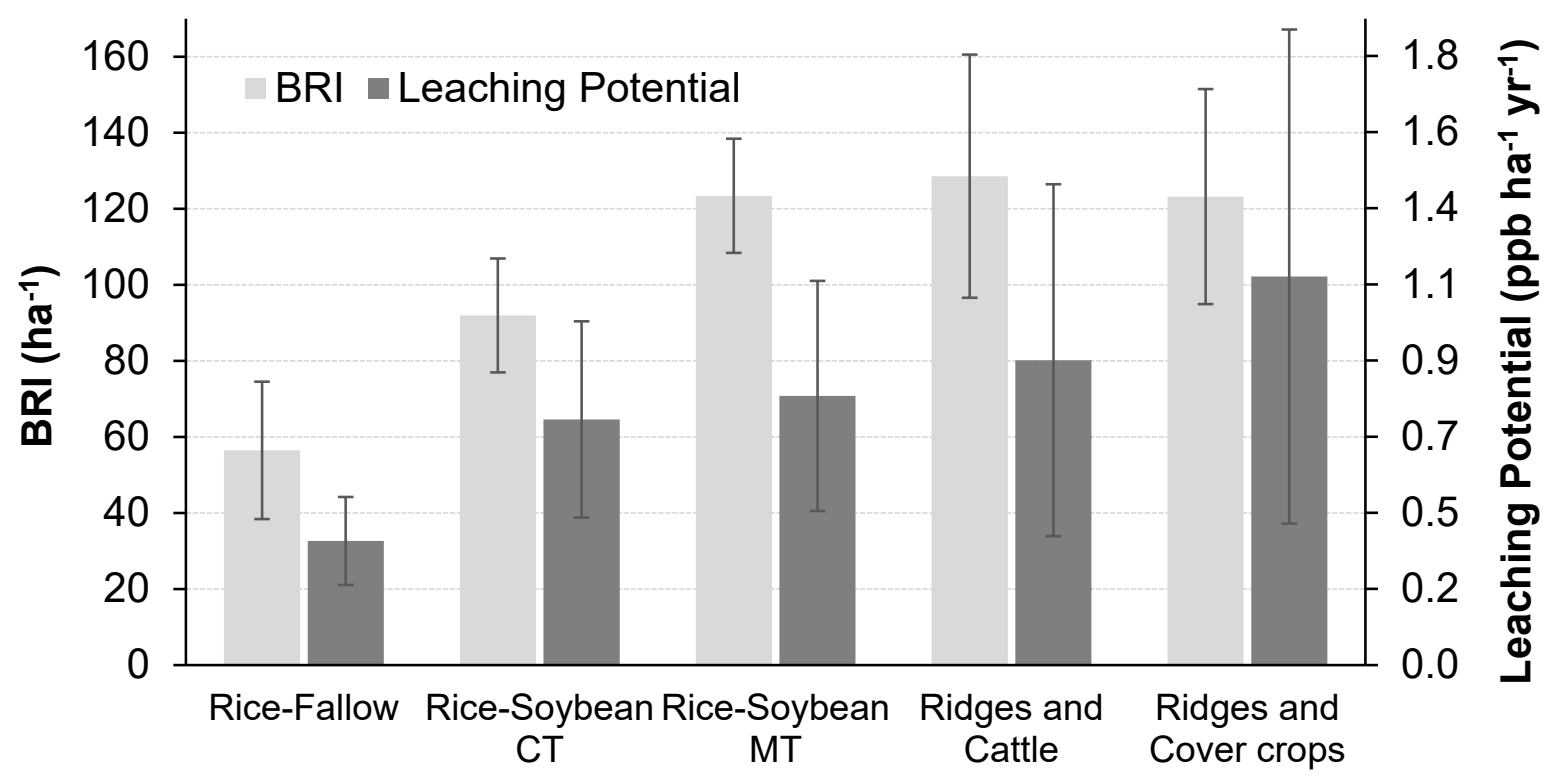

Cropping Systems

Figure 7. Average annual Biocide Residue Index (BRI ha-1 $\mathrm{yr}^{-1}$ ) and Pesticide Leaching Potential for Groundwater (PLPG; ppb ha- $\mathrm{yr}^{-1}$ ) in five cropping systems installed on an experimental station in the lowlands of south Brazil. Error bars indicate standard errors of the mean.

For the BRI-based indicator ("b" in Table 2), Rice-and Fallow was the less intensive system, whilst the Ridges and Cattle was the most intensive. The nominal difference between these two extreme cases was more than a factor two; while Rice-Fallow impacted the environment with 15.9 'BRI-units' per ton of grains produced, the system conducted on ridges needed 34.2 units. The other cropping systems presented intermediary values. For this indicator, soybean was the crop with the higher environmental footprint. No significant differences were found between maize and rice.

For the third indicator, which is based on the pesticide leaching potential weighed for grain production ("c" in Table 2), no significant differences were found ( $p=0.516)$ between the cropping systems. However, rice presented an eight times higher footprint than soybean $(p<0.05)$. This result can be attributed to the higher leaching potential of herbicides used in rice (e.g. clomazone), compared to the ones used in soybean (mostly glyphosate). 
Table 2. Annual average pesticide-intensity indicators for five cropping systems installed on an experimental station in the lowlands in south Brazil.

\begin{tabular}{lccc}
\hline Cropping systems $^{\text {a }}$ & $\begin{array}{c}\text { (a) Active ingredient } \\
\text { based indicator }\end{array}$ & $\begin{array}{c}\text { (b) Biocide Residue } \\
\text { Index based indicator }\end{array}$ & $\begin{array}{c}\text { (c) Leaching Potential } \\
\text { Based indicator }\end{array}$ \\
\cline { 2 - 4 } & g a.i. ton grains ${ }^{-1}$ & BRI ton grains $^{-1}$ & ppb ton grains $^{-1}$ \\
\hline Rice-Fallow & $185.9 \mathrm{~b}$ & $15.9 \mathrm{~b}$ & 0.103 n.s. \\
Rice-Soybean CT & {$[169.0-223.1]$} & {$[13.7-19.3]$} & {$[0.071-0.137]$} \\
& $133.4 \mathrm{~b}$ & $20.9 \mathrm{ab}$ & 0.097 \\
Rice-Soybean MT & {$[97.2-497.9]$} & {$[11.5-31.9]$} & {$[0.046-0.118]$} \\
Ridges and Cattle & $260.0 \mathrm{ab}$ & $26.7 \mathrm{ab}$ & 0.106 \\
Ridges and Cover & {$[222.1-673.1]$} & {$[19.7-43.4]$} & {$[0.043-0.128]$} \\
crops & $468.3 \mathrm{ab}$ & $34.2 \mathrm{a}$ & 0.049 \\
\multicolumn{1}{c}{ Crops ${ }^{\mathrm{b}}$} & {$[246.3-868.4]$} & {$[18.0-50.0]$} & {$[0.022-0.101]$} \\
Maize & $589.8 \mathrm{a}$ & $26.4 \mathrm{ab}$ & 0.021 \\
Rice & $360.4(102.4) \mathrm{b}$ & $20.8(5.5) \mathrm{b}$ & {$[0.017-0.099]$} \\
Soybean & $169.0(16.7) \mathrm{c}$ & $15.9(1.6) \mathrm{b}$ & $0.387(0.200) \mathrm{a}$ \\
\hline
\end{tabular}

a. Medians of an indicator followed by same letter are not significantly different $(p<0.1$ for indicator (a) and $p<0.05$ for indicator (b)). n.s. $=$ differences are not significant $(p=0.52)$. b. For crops, means of an indicator followed by same letter are not significantly different $(p<0.05)$. Values between brackets are the interquartile range [0.25- 0.75]; values between parentheses are the standard error of the mean.

\section{f) Economic performance}

Averaged over all cropping seasons, all systems returned net profits (Figure 8). Ridges and Cattle was the most profitable system, while Ridges and Cover crops was the least profitable

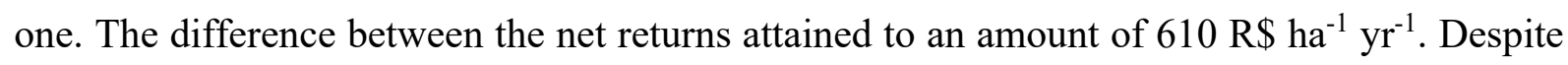
the average positive returns, all systems presented financial losses in some cropping seasons. Ridges and Cattle, for instance, was not profitable in 2 out of 9 seasons, Ridges and Cover crops was not profitable in 4 out of 9 seasons, Rice-Soybean systems presented losses in 3 out of 9 seasons; the Rice-Fallow, in turn, was not profitable in 5 out of 12 seasons (data not shown).

The financial costs varied between $2038 \mathrm{R} \$ \mathrm{ha}^{-1} \mathrm{yr}^{-1}$ and $2789 \mathrm{R} \$ \mathrm{ha}^{-1} \mathrm{yr}^{-1}$ across the cropping systems (Figure 8). Costs are important, since although they are associated to an expected return, they can also turn into monetary losses if unexpected events affect crop performance. The higher the investment, the higher the potential return, but also the higher the risk of losses. Important differences between the cropping systems were found in the variability of costs across cropping seasons. For the ridge-based systems, annual costs were around R\$ $2180 \mathrm{ha}^{-1} \mathrm{yr}^{-1}$, with a range as low as $36 \%$. Rice-Soybean presented an inter-annual cost range 
of $55 \%$ and Rice-Fallow presented a $95 \%$ difference. For this cropping system, seasons on fallow costed around $360 \mathrm{R} \$ \mathrm{ha}^{-1} \mathrm{yr}^{-1}$, while seasons with rice costed approximately ten times more $\left(\sim \mathrm{R} \$ 3700 \mathrm{ha}^{-1} \mathrm{yr}^{-1}\right)$.

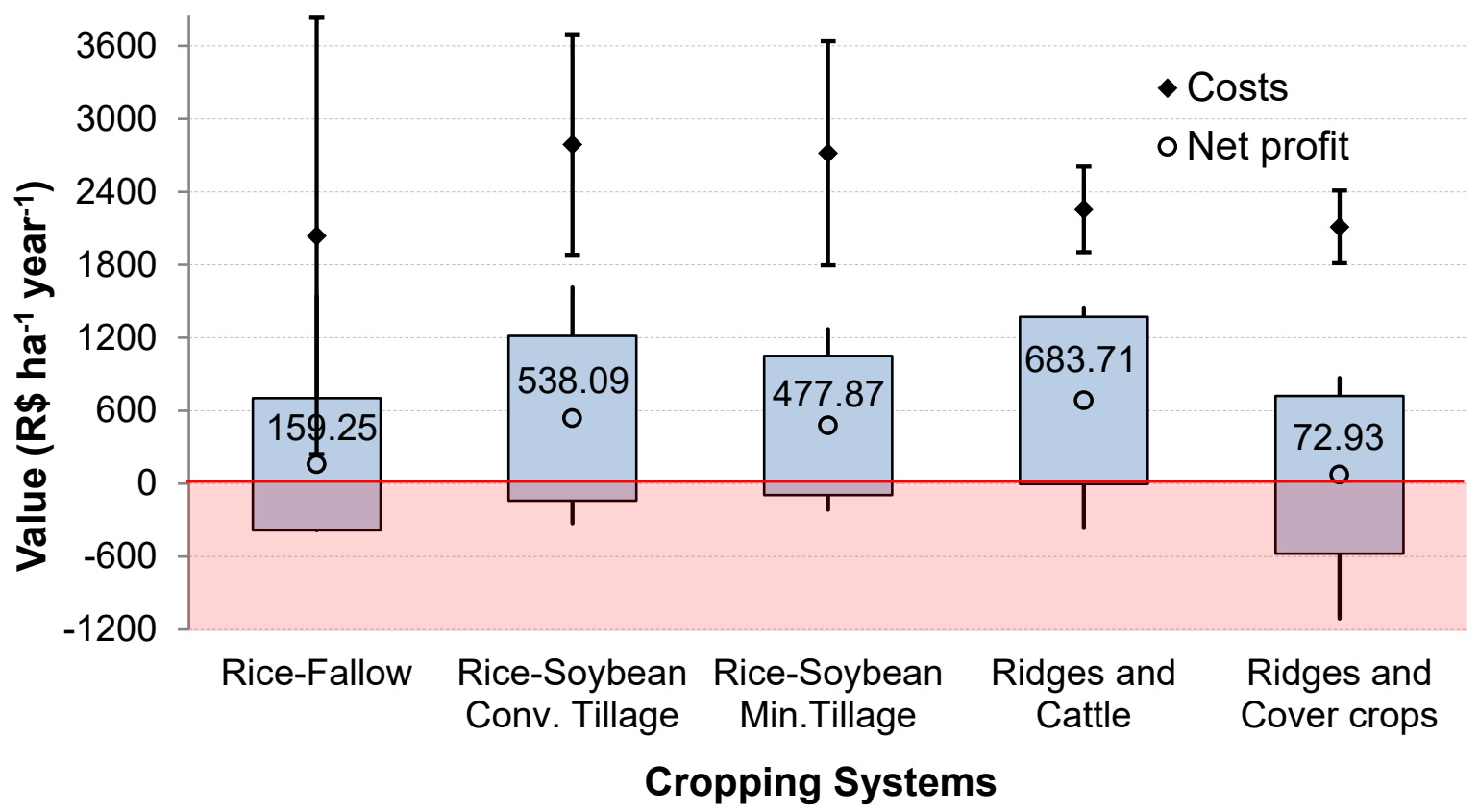

Figure 8. Annual average costs and net profit for five cropping systems in the lowlands of south Brazil. For costs, error bars indicate the standard deviation; for net profit, error bars indicate the extreme values and large bars indicate the standard deviation.

Profitability, here indicated as Economic efficiency (Table 3) is a robust indicator of efficiency, and together with the financial risks and net profits, it was included into the KPI associated to economic performance. Profitability differed between cropping systems $(p=0.04)$. Rice-Fallow distinguished itself from the other cropping system as it presented an overall negative profitability (Table 3). Most losses stem from the fallow phase (data not shown). The best cropping system under the profitability optic was Ridges and Cattle: for one Brazilian Real invested a net profit of $0.32 \mathrm{R} \$ \mathrm{yr}^{-1}$ was returned to the farmer.

\section{g) Use-efficiency indicators}

Both ridge-based systems presented a high technical efficiency for labour if compared to the traditional Rice-Fallow system (Table 3). A significant $(p<0.01)$ difference of $140 \mathrm{~kg}$ of food produced per hour of labour was observed between these cropping systems. Large differences $(p<0.01)$ also occurred for the economic efficiency of labour. For each hour of labour, the cropping systems returned from $-5 \mathrm{R} \$$ to $36 \mathrm{R} \$$ in a cropping season. Ridges and Cattle returned 
almost 5.5 times more profits per hour of work than the average of the two Rice-Soybean systems and Ridges and Cover crop. The poorest performance resulted from the Rice-Fallow system (Table 3 ).

Overall energy use-efficiency was comparable among cropping systems $(p=0.18)$ (Table 3). On average, with one MJ of energy the systems were able to produce between 2.53 to $4.18 \mathrm{MJ}$ of energy in food, which is equivalent to 180 to $257 \mathrm{~g}$ food per MJ invested. These values are comparable with values from diversified cropping systems in Canada (Zentner et al., 2004), but below indices obtained for intensive corn and soybean in USA, which attained up to $898 \mathrm{~g} \mathrm{MJ}^{-1}$ (Connor et al., 2011).

Table 3. Annual average efficiency indicators for five cropping systems in the lowlands in south Brazil.

\begin{tabular}{|c|c|c|c|c|c|}
\hline \multirow[b]{2}{*}{ Indicator } & \multicolumn{5}{|c|}{ Cropping Systems } \\
\hline & $\begin{array}{l}\text { Rice- } \\
\text { Fallow } \\
\end{array}$ & $\begin{array}{c}\text { Rice-Soybean } \\
\text { CT }\end{array}$ & $\begin{array}{c}\text { Rice-Soybean } \\
\text { MT }\end{array}$ & $\begin{array}{l}\text { Ridges and } \\
\text { Cattle }\end{array}$ & $\begin{array}{l}\text { Ridges and } \\
\text { Cover Crops }\end{array}$ \\
\hline $\begin{array}{l}\text { Economic efficiency } \\
\text { (profit investment }^{-1} \text { ) }\end{array}$ & $\begin{array}{l}-0.05 \mathrm{c} \\
(0.11)\end{array}$ & $\begin{array}{c}0.16 \mathrm{ab} \\
(0.07)\end{array}$ & $\begin{array}{c}0.18 \mathrm{ab} \\
(0.07)\end{array}$ & $\begin{array}{l}0.32 \mathrm{a} \\
(0.11)\end{array}$ & $\begin{array}{c}0.10 \mathrm{bc} \\
(0.10)\end{array}$ \\
\hline $\begin{array}{l}\text { Technical efficiency } \\
\left.\text { (kg food h } \text { labor }^{-1}\right)\end{array}$ & $\begin{array}{c}43.6 \mathrm{~b} \\
{[16.2-69.9]}\end{array}$ & $\begin{array}{c}88.6 \mathrm{ab} \\
{[79.9-99.7]}\end{array}$ & $\begin{array}{c}96.7 \mathrm{ab} \\
{[78.0-113.6]}\end{array}$ & $\begin{array}{c}180.3 \mathrm{a} \\
{[164.9-336.2]}\end{array}$ & $\begin{array}{c}186.8 \mathrm{a} \\
{[159.8-381.3]}\end{array}$ \\
\hline 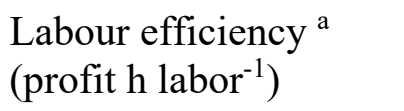 & $\begin{array}{l}-5.20 \mathrm{~b} \\
(5.08)\end{array}$ & $\begin{array}{l}4.66 \mathrm{~b} \\
(3.76)\end{array}$ & $\begin{array}{l}9.55 \mathrm{~b} \\
(6.30)\end{array}$ & $\begin{array}{l}36.43 \mathrm{a} \\
(11.76)\end{array}$ & $\begin{array}{l}5.84 \mathrm{~b} \\
(12.43)\end{array}$ \\
\hline $\begin{array}{l}\text { Energy use-efficiency } \\
\left(\mathrm{MJ} \text { food } \mathrm{MJ}^{-1}\right)\end{array}$ & $\begin{array}{l}2.53 \mathrm{~b} \\
(0.54)\end{array}$ & $\begin{array}{c}3.56 \mathrm{ab} \\
(0.36)\end{array}$ & $\begin{array}{l}3.68 \mathrm{a} \\
(0.31)\end{array}$ & $\begin{array}{l}4.18 \mathrm{a} \\
(0.74)\end{array}$ & $\begin{array}{l}3.72 \mathrm{a} \\
(0.56)\end{array}$ \\
\hline $\begin{array}{l}\text { Fuel use-efficiency }{ }^{b} \\
\left(\mathrm{MJ} \text { food MJ diesel }{ }^{-1}\right)\end{array}$ & $\begin{array}{c}5.70 \mathrm{~b} \\
{[0.9-8.1]}\end{array}$ & $\begin{array}{l}8.04 \mathrm{ab} \\
{[6.7-8.6]}\end{array}$ & $\begin{array}{c}8.95 \mathrm{ab} \\
{[7.8-10.2]}\end{array}$ & $\begin{array}{c}10.52 \mathrm{a} \\
{[9.1-20.2]}\end{array}$ & $\begin{array}{c}9.18 \mathrm{a} \\
{[8.3-22.1]}\end{array}$ \\
\hline $\begin{array}{l}\text { N use-efficiency }{ }^{b} \\
\left(\text { MJ grains } \mathrm{MJ} \mathrm{N}^{-1}\right)\end{array}$ & $\begin{array}{c}17.0 \mathrm{ab} \\
{[13.9-27.0]}\end{array}$ & $\begin{array}{c}24.0 \mathrm{a} \\
{[15.2-66.8]}\end{array}$ & $\begin{array}{c}20.1 \mathrm{ab} \\
{[15.2-66.2]}\end{array}$ & $\begin{array}{c}14.2 \mathrm{ab} \\
{[12.7-16.8]}\end{array}$ & $\begin{array}{c}12.7 \mathrm{~b} \\
{[11.4-15.8]}\end{array}$ \\
\hline
\end{tabular}

a. Means and standard error of the mean. b. Medians and interquartile range [0.25-0.75]. Means and medians in a row followed by same letter are not significantly different at a level of $p=0.05$.

For fuel use-efficiency, cropping systems based on the ridges were more efficient $(p<0.05)$ than the Rice-Fallow system (Table 3$)$. Ridge-based systems produced 4.2 MJ more food (energy based) than Rice-Fallow per unit of energy consumed as diesel, a difference equivalent to $7.3 \mathrm{~kg}$ food per litre of fuel. Nitrogen use-efficiency was also distinctly different $(p<0.05)$ between cropping systems. Under the optics of this indicator, Rice-Soybean CT was the most effective system, and the Ridges and Cover crops was least effective. Cropping systems conducted on ridges were apparently inefficient in converting nitrogen to food. Such 
results, however, are consistent with the dynamics of fertilizer use in these systems: whilst in the rice-based systems the fertilizers were applied directly in the grain crops, in the ridge-based systems part of the nitrogen was applied during winter, to the benefit of pastures and cover crops.

\section{h) Key performance indicators (KPIs)}

The five KPIs adopted in this study correspond to common and recurrent issues which affect agricultural systems: environmental impact, land use-efficiency, economics on farm production, energy use efficiency and labour. Although other multi criteria analysis commonly focus on three dimensions (environmental, agronomic, and economics), we included energy use-efficiency and labour since they are a relevant topic nowadays, they are useful to better understand the cropping systems and because our records have enough information to analyse this item appropriately.

For the environmental dimension, Rice-Fallow was the cropping system with the highest position in the ranking (Figure 9). Such result originates, at least in part, from the relatively long period on fallow ( 6 out 12 years), a time in which no pesticides are applied, and the overall energy, fuel, fertilizers, machinery and labour are used at minimum level. Within the systems with permanent cultivation, the ridge-based models seem to offer a better result than ricesoybean systems for the Key Performance Indicator associated to environment.

The KPI 'Primary land production' clearly pictured the differences between the cropping systems over the land-use dimension. The systems conducted on ridges ranked high, followed by intermediate positions for rice-soybean rotations, with Rice-Fallow in the last position. This result reflects the high biomass production and the high food production per unit of land of the ridge-based systems. These results reinforce crop-livestock integration as an interesting way to attain sustainable intensification, confirming the results of Faccio Carvalho et al. (2010) and Sá et al. (2013).

In the radar plot, the two rice-soybean systems showed a large degree of similarity. The system conducted in minimum tillage ranked better with regards to the KPI Labour, while the conventional tillage system performed slightly better for the KPIs Environment and Primary land production. Apparently, the claimed advantages from minimum tillage (e.g. environmentally friend and highly productive) were not captured by the framework designed to compare these cropping systems as a whole. This partly resulted from the Rice-Soybean CT using fewer pesticides and producing a little more grains than the minimum-tillage system. 
Although these differences were not significant, they affected the performance of other indicators and, as an overall outcome, the KPI plot represented these accumulated differences appropriately.

Economic performance was distinct between the cropping systems, which formed clearly three ranking groups. Ridges and Cattle performed best, followed by both rice-soybean rotations. The last group was composed of Rice-Fallow and Ridges and Cover crops systems, which gave the poorest performance. Not surprisingly, these last cropping systems also provided the smallest net profit (Figure 8).

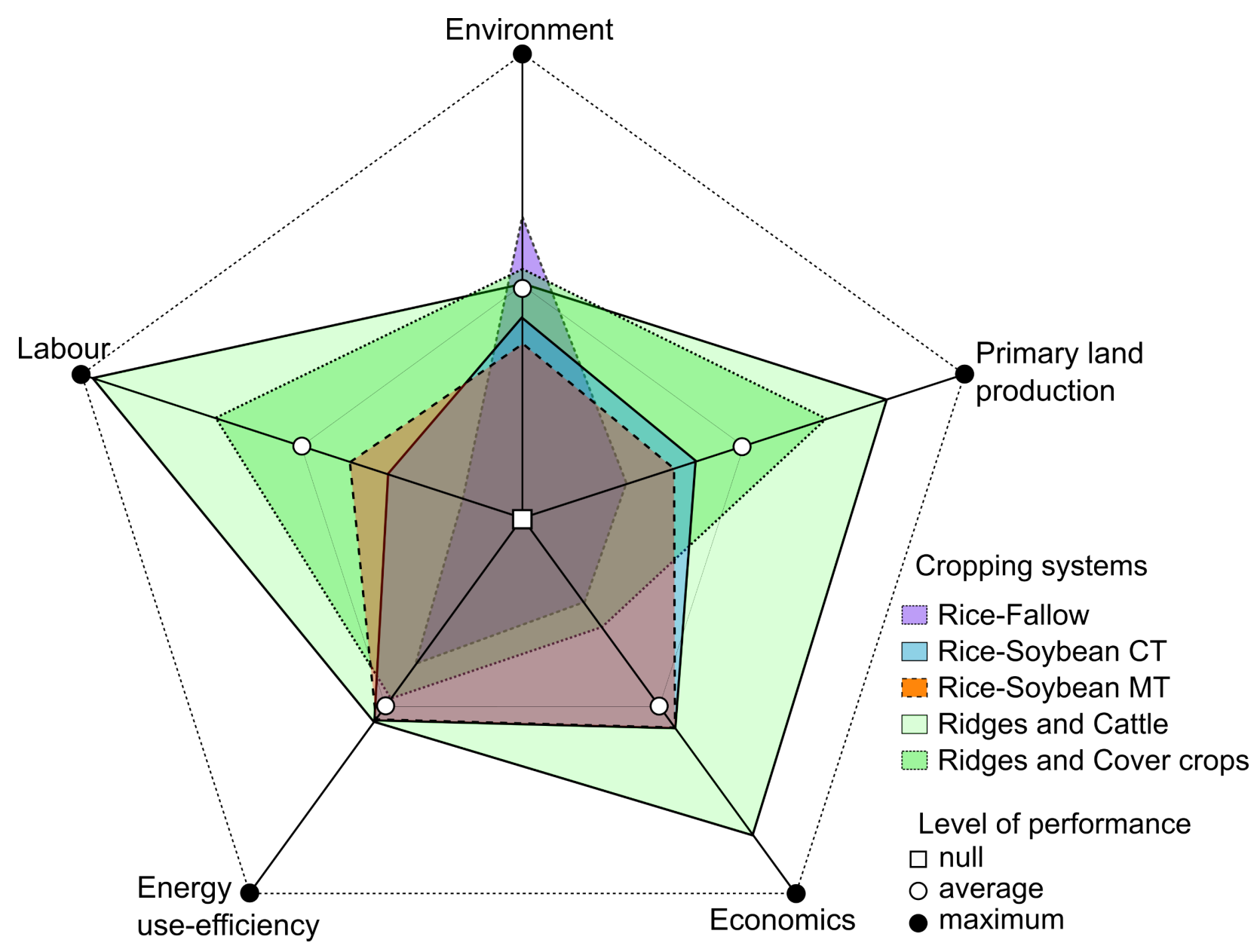

Figure 9. Ranking of Key Performance Indicators (KPIs) for five cropping systems in lowlands of south Brazil. The distance away from the centre of the plot indicates the relative performance of a cropping system for a given KPI.

Of all KPIs, Energy use-efficiency showed the smallest differences between the cropping systems. Within a scale from 0 to 2, calculated ranks were located between 0.78 (Rice- 
Fallow) and 1.09 (Ridges and Cattle). The small range of differences, however, does not mean that the systems do not differ in some aspects, neither that opportunities to improve the cropping system do not exist (e.g. reducing energy in soil preparation, as identified for rice-soybean rotations). Rice-Fallow seems to perform slightly poorer than the other cropping systems, followed by Ridges and Cover crops. Both rice-soybean systems and the Ridges and Cattle performed best, and presented very similar outcomes for energy-use efficiency.

The larger differences between the cropping systems occurred over the social dimension (the KPI Labour). The highest (1.99) and lowest (0.26) ranks were calculated for Ridges and Cattle and for Rice-Fallow, respectively. The reduced number of hours of field work, plus the high returns on profitability and food production confirm the advantages of the systems based on ridges. Such result can be interpreted as a stimulus for those farmers who, under the argument of a limited labour availability, are hesitant to include a more diversified production model next to their rice-based systems.

Overall, the Ridges and Cattle system presented the highest performance ranking for 3 out of 5 KPIs. This innovative system was clearly advantageous on labour (social), land use and economic dimensions, also presenting high scores for the KPI Energy use-efficiency (Figure 9). Ridges and Cover crops, despite being ranked as the second-best position for the KPIs Environment, Primary land production and Labour, presented poor for the economic dimension, scoring similar to the traditional Rice-Fallow system for this KPI. The explanation for such a weak performance is the considerable amount of resources applied in the cover crop phase. Although this stimulated biomass production (Figure 3) and soil quality (SOM, data not presented), these outcomes were not enough to promote a consistent increase in energy useefficiency and, especially, in the economic performance of this cropping system.

\subsection{Discussion}

From an agricultural point of view, there is a need to develop lowland cropping systems able to overcome the limitations associated to high soil moisture, as this hampers crop diversification. Diversification is an important prerequisite for sustainable systems and to increase the regional development (Rocha, 2011). Compared to the monocrop-based rice-fallow system, the models consisting of a rotation of rice and soybean can be considered an important advance, although opportunities to make lowland cropping systems more sustainable still exist. This motivated us to study distinct alternatives for the agricultural production in lowlands. Consequently, next to the traditional rice-fallow and two modern rice-soybean systems, two innovative ridge-based 
models were evaluated. Since these production models differ substantially, a structured multicriteria approach was developed to facilitate a rigid and robust evaluation based on five Key Performance Indicators.

\section{The cropping systems}

Rice-Fallow is the most used cropping system in the southern Brazilian lowlands. Tradition is an important reason for many farmers to stick to this system (Benetti, 2007), which represents a relatively low level of 'artificialization' of the ecosystem. Our analysis revealed some quantifiable characteristics supporting the prevalence of this system in the temperate wetlands. Rice-Fallow presented the smallest energy demand, the lowest use of pesticides, fertilizers and seeds, and on average the lowest monetary investments relative to the other cropping systems. From a risk perspective, costs are an important issue, since many rural enterprises do not have access to cheap farm loans (Leite \& Wesz Jr., 2014), pre-agreed sales (Capitani, 2013) or farming insurances (Ozaki, 2013). In fact, high production costs are one of the largest threats to economic sustainability of rice production in southern Brazil (Barata \& Toledo, 2015).

Despite the positive characteristics mentioned above, Rice-Fallow has intrinsic limitations associated to the rice production in monoculture and a relatively 'low-tech' cattle production. This became apparent when Rice-Fallow was contrasted to the other production models, and was shown to be a non-land-saving system. Because of the low primary land production, traditional Rice-Fallow has gradually been substituted by more intense models of agricultural production in the paddies of extreme south of Brazil. These modified models can be regarded as a high input version of the rice-fallow concept, or a rice crop rotation system, in which soybean is the crop commonly alternated with irrigated rice. The extent to which these changes are put into practice depends on the availability of financial assets and training programs and the awareness of extension services (Coronel et al., 2007; Rocha, 2011).

The two methods of soil management evaluated in connection to the rice-soybean rotation, conventional and minimum tillage, are both used in the lowlands of southern Brazil. The choice for either one of the two methods not only depends on soil and climatic conditions, but is to a large extent a matter of farmer's preference. We measured a clear distinction between Rice-Soybean CT and Rice-Soybean MT for a number of characteristics, following the differences in soil preparation. Savings of around 50\% for fuels and labour time were observed in favour of minimum tillage. However, when compared to ridge-based systems, which are entirely based on no-till, resource use for soil management in these rice-soybean systems was 
still high. This difference prompts us to seek for improvements in rice-soybean cultivation. In this context, a labour and energy saving soil preparation based on the knife-roller system (Silva et al., 2012) seems a promising alternative.

Cropping systems based on reduced soil disturbance, such as Rice-Soybean MT and both ridge-based systems, carried however a drawback from the environmental point-of-view, represented by the large reliance on herbicides. In fact, minimum tillage rice-soybean used almost the double of the amount of herbicides when compared to this rotation conducted in conventional tillage. Besides that, the ridge-based systems, managed entirely in no-tillage, exceeded the herbicide use in minimum-till. The ridge-based cropping systems consumed more pesticides, resulting in a high biocide residue index and, in some instances, a higher amount of active ingredients per unit of grains produced. Obviously, there is plenty of room for improvement regarding pesticide use in the ridge-based systems.

From a farmer's perspective, one of the most important indicators in a systems comparison is the economic performance. The current analysis made clear that all cropping systems faced financial losses in some seasons. Both Rice-Soybean systems and Ridges and Cattle stood out with net profits at least 3 times higher than Rice-Fallow and a profitability 1.6 to 3.2 times higher than that of Ridges and Cover Crops. Two positive aspects observed in the ridge-based systems were the slightly lower costs than in the rice-soybean models and overall the lower variance of costs between cropping seasons. Evidently, a small variation in investments represents a more uniform monetary risk, which can reduce threats of bankruptcy in case of a catastrophic event such as flooding, drought or an uncontrolled pest outbreak. Rice and Cattle, as a model with more sources of incomes (soybean, maize and cattle) provided stable profits in the long run. This system resulted in a $27 \%$ higher net profit and offered a 2 times higher economic efficiency than the second most profitable system (Rice-Soybean CT). These results confirm that a well-conducted integration between crops and cattle production enables the system to deliver superior technical and economic performances (e.g. de Moraes et al., 2014).

\section{Processes analysis and key performance indicators}

The systems that were investigated in this study differ substantially. Rice is the main crop in lowlands, where the rice-fallow and the rice-soybean rotation system prevail, whereas rice is substituted by other crops in the ridge-based systems. Such differences complicate a straightforward comparison of cropping systems. For that reason, we decided to develop a two- 
step approach. Process Analysis (PA), used as a first step, is a robust and transparent means of collecting information, since it is based on a systematic hierarchical listing of field activities. In this step information was synthesized in 21 primary indicators, that enabled to identify specific differences between the systems under study. A clear example is the symmetry found in the two rice-soybean systems regarding the environmental impact of seedbed preparation: while conventional tillage required $96 \%$ more energy for soil preparation, minimum till required 96\% more herbicides to make an appropriate seedbed for crop seeding. These numbers confirm the criticism that conservation agriculture substitutes soil preparation for pesticides (Giller, 2012). In a second step, the primary indicators were used as a basis for five key performance indicators (KPIs) that represent the functioning of a system regarding environment, primary land productivity, economics, energy use efficiency and labour. By summarizing the information in this way and presenting them in a spider diagram (Figure 9), strength and weaknesses of the various cropping systems could easily be perceived.

In business management, KPIs are translated into specific targets to be pursued by a company. Although the method can be criticized for its specificity, it is a powerful tool to integrate distinct goals under a same metric, making them comparable. Performance indicators also allow to monitor the defined targets in regular intervals, and can even be used to assess the objectives in real time. In the current analysis, we did not monitor the cropping systems at regular intervals, but rather analysed their performance based on accumulated long-term results. In this case, evaluation in a longer-term perspective makes sense as agricultural dynamics (prices, weather, crops and environmental interactions) typically vary from season to season and this can bias the results. Hence, instead of depending on single-year data, the information from each cropping season was averaged over nine years to create a more stable ranking of sustainability.

The key performance indicators chosen to rank the cropping systems represent a structured arrangement of general themes which are known to affect farms, not only in the lowlands, but also in other agricultural systems. To make the analysis more meaningful for cropping systems in lowlands, some of the primary indicators were purposely constructed to express the vulnerabilities connected to this agro-environment. Vulnerability in this sense is defined as the convergence of conditions (environmental, biological and economical) that increase the susceptibility to the impact of a given risk (Tominaga, 2009). For example, the inherent abundance of water makes lowlands admittedly more vulnerable to risks of water contamination by pesticides and nitrogen compounds than uplands. Based on such 
considerations, pesticide leaching and nitrogen use were included as primary indicators. This example illustrates that KPIs can be tailored to appropriately connect to the specific sustainability aspects of the systems under study.

Flexibility of the framework can also be realized in another way: by modifying the relative importance of primary indicators within a KPI. Putting different weights to specific primary indicators enables adjustments that allow to better capture nuances and trade-offs that are characteristic of the cropping system under study. In our case for example, the primary indicators associated to pesticide use were weighted with a factor $1 / 3$, to avoid an overrepresentation of this aspect in the KPI 'Environment'. The drawback of these adjustments is that attributing different weights can be rather subjective (Martinez-Alier et al., 1998; Perret, 2002), and it therefore has to be clearly communicated to maintain transparency and used with care to avoid bias in results.

Some primary indicators influence the system in different ways. The logical implication was that some of the data were used for the calculation of more than one KPI. Biomass production, for example, was directly used for the KPI 'Primary land production', as it represents food and biomass production per unit of land. This trait was however also used to calculate carbon sequestration, which forms part of the KPI 'Environment'. The KPI's, representing the various dimensions of sustainability, are partially overlapping and are not completely independent (Butlin, 1989). Rather than applying strict borders, the recognition of these overlaps is essential for creating the best possible view of a cropping system and for its comparison with the other systems. The correct treatment for these overlapping cases and the simultaneous evaluation of sustainability from a wide array of perspectives is crucial. By doing so, we avoid the mentioned obvious anomalies (Farrell, 1957) -which are, in essence, a biased interpretation of the outcomes due the lack of evidences- thus enabling a robust and genuine system's assessment.

Another important advantage of the integrated framework over using a simpler analysis is its capacity to make seemingly small nuances between cropping systems better visible. Differences observed between conventional and minimum-till rice-soybean rotations (pesticides vs soil preservation), or between both ridge-based systems (profits vs priority on cover crops) are examples of this. Analysis using the integrated framework also made clear that, under the experimental conditions, the simple use of cover crops did not reduce the overall energy input related to fertilizers. Additionally, the KPI radar-plot neatly summarized the information regarding the cropping systems and enabled a comprehensive, but quick and easy, 
comparison between them.

\subsection{Final remarks}

At times in which the proper notion of agricultural efficiency is difficult to establish, and sustainability can be perceived from many different perspectives, the design of new cropping systems is a challenging task. This manuscript covers part of a long-term study were we purposely contrasted a traditional, two modern and two innovative cropping systems. The challenge was to intelligently summarize the large set of information collected in nine consecutive years. To cope with this task, methods usually applied in the field of process engineering and business were used. Cropping systems were dismantled in logical parts, in- and outputs were measured, indicators were generated and adjusted to a comparable scale and a ranking of systems was created for five distinct dimensions of sustainability.

The cropping system based on rice and fallow, currently still predominant in the southern Brazilian lowlands, is a logical option for this environment, since rice is well adapted to soil flooding and livestock production is one of the most important economic activities at regional level. Compared to other cropping systems, Rice-Fallow required less energy, presented, on average, the lowest cost and used less pesticides. However, the system turned out to be a land-wasting model of production due the inherent time without any grain crop cultivation. The cropping system presented well for the environmental dimension, but was the weakest performer for the other four Key Performance Indicators estimated in our analysis.

The rotation system composed of irrigated rice and soybean is currently the main option for crop diversification in the southern Brazilian lowlands. It can be considered a modern cropping system, since it combines the convenience of being fully adjusted to the current market demand for soybean, concomitant to providing technical benefits to rice production. Ricesoybean was evaluated under both conventional tillage and minimum tillage, and, except for the environmental dimension, Rice-soybean performed better than Rice-Fallow for all the other Key Performance Indicators. This result explains why these cropping systems are slowly substituting the Rice-Fallow system in the south Brazilian lowlands.

The systems conducted on ridges are markedly different from the models managed in flat soil. The permanent structure to keep the soil dry enables the fields to be cultivated with species not tolerant to high levels of soil humidity, and to obtain the benefits from techniques typical of conservation agriculture, like no-tillage, use of cover crops and crop-livestock 
integration, which are admittedly connected to sustainability. Production of biomass was strongly favoured in both ridge-based systems due the favourable soil conditions encountered during winter time. Both ridge-based models were however characterized by a high dependency on herbicides, revealing clear opportunities for further improvement. The results further showed that giving priority to controlled consumption of exceeding biomass by cattle, rather than just cover crops, does represent economic and technical benefits. It thus became evident that the integration of cattle with summer crops in a field managed with large ridges can be an attractive alternative for diversifying agricultural production in lowlands.

Finally, the PA-KPI framework, besides its powerful ability to analyse and compare diverse cropping systems, showed to be a good communication tool. Complex data were logically condensed into a single rank, and, rather than difficult to interpret indicators, a coherent and balanced set of sustainability aspects was used to express the results. Hence, in a single snapshot, essential information regarding system performance was made promptly available. The framework can also be amended for application in agricultural systems other than the lowlands. We are convinced that this approach is a robust method of analysis and can help decision-makers to choose the best possible alternatives for a more sustainable agriculture.

\subsection{References}

Aita C \& Giacomini S (2003) Decomposição e liberação de nitrogênio de resíduos culturais de plantas de cobertura de solo solteiras e consorciadas. Revista Brasileira de Ciencia do Solo 27, 601-612.

AlEXANDRATOS N \& BRUINSMA J (2012) World agriculture towards 2030/2050 - the 2012 revision. ESA Working paper - FAO 12, 147.

Alipour A, Veisi H, Darijani F, Mirbagheri B \& Behbahani A (2012) Study and determination of energy consumption to produce conventional rice of the Guilan province. Research in Agricultural Engineering 58, 99-106.

BACK ÁJ, Deschamps FC \& SAntos MdGdS (2016) Ocorrência de agrotóxicos em águas usadas com irrigação de arroz no sul de Santa Catarina. Revista Brasileira de Ciências Ambientais 39, 47-58.

Balbinot Junior AA, Moraes Ad, Veiga Md, Pelissari A \& Dieckow J (2009) Integração lavoura-pecuária: intensificação de uso de áreas agrícolas. Ciencia Rural 39, 1925-1933.

BARATA TS \& TOLEDO R (2015) Mensuração do custo de produção de arroz irrigado no Rio Grande do Sul safra 2014/2015. (Assessment of production costs of irrigated rice in RS state, Brazil, in 2014/2015 cropping season). 19p. Ministério da Agricultura, Pecuária e Abastecimento, Brasília, Brazil.

Barretto AGOP, Berndes G, Sparovek G \& Wirsenius S (2013) Agricultural intensification in Brazil and its effects on land-use patterns: An analysis of the 19752006 period. Global Change Biology 19, 1804-1815. 
BENETTI MD (2007) Perspectivas de transformações estruturais na economia da Metade Sul do Estado. Indicadores Econômicos FEE 34, 129-142.

Bimonte S, NAOUfal E \& Gineste L (2016) A system for the rapid design and implementation of Personalized Agricultural Key Performance Indicators issued from sensor data. Computers and Electronics in Agriculture 130, 1-12.

Bowers W (1992) Agricultural field equipment. In: Energy in farm production, Vol. 6. (ed RC Fluck), 1 edn, 117-130. Elsevier, Amsterdam.

BuENo AdCeS \& LEMos CAS (2006) Levantamento da fertilidade do solo cultivado com arroz irrigado no município de Uruguaiana. Revista da FZVA 13, 41-51.

Bundt ADC, Avila LAd, Pinto JJdO, Santos TTd, Agostinetto D \& Martins K (2013) Transporte ascendente da mistura formulada de imazethapyr e imazapic em resposta à profundidade do lençol freático. Ciencia Rural 43, 1597-1604.

ButLin J (1989) Our common future. By World commission on environment and development.(London, Oxford University Press, 1987, pp. 383£ 5.95.). Wiley Online Library.

CÁCERES DM (2015) Accumulation by Dispossession and Socio-Environmental Conflicts Caused by the Expansion of Agribusiness in Argentina. Journal of Agrarian Change 15, 116-147.

CAPITANi DHD (2013) Viabilidade de implantação de um contrato futuro de arroz no Brasil (The feasibility of a rice futures contract in Brazil). Doctoral Thesis, Universidade de São Paulo - Escola Superior de Agricultura Luiz de Queiroz, Piracicaba, Brazil.

CARVALHO PTD (2012) Balanço de emissões de gases de efeito estufa de biodiesel produzido a partir de soja e dendê no Brasil. Master, Universidade Federal do Rio de Janeiro, Rio de Janeiro, Brazil.

CoE MT, MARTHEws TR, Costa MH et al. (2013) Deforestation and climate feedbacks threaten the ecological integrity of south-southeastern Amazonia. Philos Trans $R$ Soc Lond B Biol Sci 368.

CONNOR D, LOOMIS RS \& CASSMAN KG (2011) Crop ecology: productivity and management in agricultural systems, 2nd. edn. Cambridge University Press, Cambridge.

Coronel DA, Alves FD \& Silva MAE (2007) Notas sobre o processo de desenvolvimento da metade sul e norte do estado do Rio Grande do Sul: uma abordagem comparativa. Perspectiva Econômica 3, 27-43.

de Moraes A, Carvalho PCdF, Anghinoni I, Lustosa SBC, Costa SEVGdA \& Kunrath TR (2014) Integrated crop-livestock systems in the Brazilian subtropics. European Journal of Agronomy 57, 4-9.

Dejaco MC, Re Cecconi F \& Maltese S (2017) Key Performance Indicators for Building Condition Assessment. Journal of Building Engineering 9, 17-28.

ERIKSSON M \& AHLGREN S (2013) LCAs for petrol and diesel - a literature review. 36. Swedish University of Agricultural Sciences, Uppsala.

ESTES TL, PAI N \& WINCHELL MF (2016) Comparison of predicted pesticide concentrations in groundwater from SCI-GROW and PRZM-GW models with historical monitoring data. Pest Management Science 72, 1187-1201.

Faccio Carvalho PC, Anghinoni I, Moraes A et al. (2010) Managing grazing animals to 
achieve nutrient cycling and soil improvement in no-till integrated systems. Nutrient Cycling in Agroecosystems 88, 259-273.

FAGERIA NK, WANDER AE \& SiLVA SC (2014) Rice (Oryza sativa) cultivation in Brazil. Indian Journal of Agronomy 59, 350-358.

FAO (2003) World Agriculture: towards 2015/30 - an FAO perspective., (ed. FaaO (Fao)). Earthscan Publications Ltd, London.

FARRELl MJC (1957) The Measurement of Productive Efficiency. Journal of the Royal Statistical Society. Series A (General) 120, 253-290.

FERREIRA FDF, NEUMANN PS \& HOFFMANN R (2014) Análise da matriz energética e econômica das culturas de arroz, soja e trigo em sistemas de produção tecnificados no Rio Grande do Sul. Ciencia Rural 44, 380-385.

Filipe BK, Celio I C, Guilhem M, Esteban A P \& Oscar J S (2013) Desplazamiento de la ganadería por la agricultura en una cuenca de La Pampa ondulada: Efectos sobre el escurrimiento superficial y erosión hídrica. Ciencia del suelo 31, 83-92.

Foley JA, RAmankutty N, Brauman KA et al. (2011) Solutions for a cultivated planet. Nature 478, 337-342.

Froehlich JM, RAuber CDC, CARPES RH \& TOEBE M (2011) Êxodo seletivo, masculinização e envelhecimento da população rural na região central do RS. Ciencia Rural 41, 6.

GILLER KE (2012) Conservation: No silver bullets for African soil problems. 485, 41-41.

Gomes AdS, Petrini JA \& FAgUndes PRR (2004) Manejo racional da cultura do arroz irrigado "Programa Marca", (ed. PRR Fagundes). Embrapa Clima Temperado, Pelotas, Brazil.

Goulart ICGR, Borba TCO, Menezes VG \& Merotto A (2014) Distribution of weedy red rice (Oryza sativa) resistant to imidazolinone herbicides and its relationship to rice cultivars and wild Oryza species. Weed Science 62, 280-293.

Grützmacher DD, GrÜtzmacher AD, Agostinetto D, Loeck AE, Roman R, Peixoto SC \& ZANELLA R (2008) Monitoramento de agrotóxicos em dois mananciais hídricos no sul do Brasil. Revista Brasileira de Engenharia Agricola e Ambiental 12, 632-637.

HAVEMAN ABM (2013) Risk assessment of crop production in Brazil. Master Master, Wageningen University, Wageningen, Netherlands.

IBGE (2015) IBGE - Produção Agrícola Municipal. In: Monthly. Instituto Brasileiro de Geografia e Estatistica, Brasilia, Brasil.

IPCC (2006) 2006 IPCC Guidelines for National Greenhouse Gas Inventories. Agriculture, Forestry and Other Land Use., (eds. K Paustian, NH Ravindranath \& AV Amstel). Institute for Global Environmental Strategies, Hayama, Japan.

IRGA (2014) Custo de produção de arroz irrigado médio ponderado no Rio Grande do Sul. Sistema de cultivo mínimo (semi direto). Estimativa da safra 2013/14. In: Custo de Produção de Arroz. (ed SDP Setorial), 55. Instituto Rio Grandense do Arroz, Porto Alegre, Brazil.

KONG XB, LAL R, LI BG et al. (2014) Fertilizer Intensification and its Impacts in China's HHH Plains. Advances in Agronomy, Vol 125 125, 135-169.

LEITE SP \& WESZ JR. VJ (2014) Estado, políticas públicas e agronegócio no Brasil: revisitando 
o papel do crédito rural. Revista Pós Ciências Sociais 11, 83-108.

LIN H-C \& HÜLSBERgen K-J (2017) A new method for analyzing agricultural land-use efficiency, and its application in organic and conventional farming systems in southern Germany. European Journal of Agronomy 83, 15-27.

LunN DJ, Thomas A, Best N \& SPIEgelhalter D (2000) WinBUGS - A Bayesian modelling framework: Concepts, structure, and extensibility. Statistics and Computing 10, 325337.

MANTOAm EJ, Romanelli TL \& Gimenez LM (2016) Energy demand and greenhouse gases emissions in the life cycle of tractors. Biosystems Engineering 151, 158-170.

Martinez-Alier J, Munda G \& O'Neill J (1998) Weak comparability of values as a foundation for ecological economics. Ecological Economics 26, 277-286.

Menezes VG, ANGHINONi I, Silva PRF et al. (2012) Projeto 10: estratégias de manejo para aumento da produtividade e da sustentabilidade da lavoura de arroz irrigado do RS: avanços e novos desafios., (ed. Irga). Instituto Riograndense do Arroz, Porto Alegre, Brazil.

Menezes VG, Mariot CHP, Kalsing A \& Goulart ICGR (2009) Arroz-vermelho (Oryza sativa) resistente aos herbicidas imidazolinonas. Planta Daninha 27, 1047-1052.

MEYFroidt P, CARLSON KM, FAGAN ME et al. (2014) Multiple pathways of commodity crop expansion in tropical forest landscapes. Environmental Research Letters 9.

NATURE (2010) How to feed a hungry world. Nature 466, 531-532.

Niedertscheider M, Kastner T, Fetzel T, Haberl H, Kroisleitner C, Plutzar C \& Erb KH (2016) Mapping and analysing cropland use intensity from a NPP perspective. Environmental Research Letters 11.

NiU W, Han L, LiU X, HuAng G, Chen L, XIAO W \& YANG Z (2016) Twenty-two compositional characterizations and theoretical energy potentials of extensively diversified China's crop residues. Energy 100, 238-250.

NORSE D \& JU XT (2015) Environmental costs of China's food security. Agriculture Ecosystems \& Environment 209, 5-14.

OZAKI VA (2013) Qual o custo governamental do seguro agrícola? Revista de Economia e Sociologia Rural 51, 123-136.

PANDEY D \& Agrawal M (2015) Carbon Footprint Estimation in the Agriculture Sector. In: Assessment of Carbon Footprint in Different Industrial Sectors, Vol. 1. (ed SS Muthu). Springer Science and Business Media Singapore.

PARMENTER D (2015) Key Performance Indicators: Developing, Implementing, and Using Winning KPIs. John Wiley \& Sons.

PATHAK H, SAHARAWAT YS, GATHALA M \& LADHA JK (2011) Impact of resource-conserving technologies on productivity and greenhouse gas emissions in the rice-wheat system. Greenhouse Gases: Science and Technology 1, 261-277.

Peral J, Maté A \& Marco M (2017) Application of Data Mining techniques to identify relevant Key Performance Indicators. Computer Standards and Interfaces 50, 55-64.

PERRET B (2002) Indicateurs sociaux, état des lieux et perspectives. In: Les papiers du CERC, Vol. 1, 8, Paris. 
PIMENTEL D (1992) Energy inputs in production agriculture. In: Energy in farm production, Vol. 6. (ed RC Fluck), 1 edn, 13-29. Elsevier, Amsterdam.

Pittelkow CM, Zorrilla G, Terra J, Riccetto S, Macedo I, Bonilla C \& Roel A (2016) Sustainability of rice intensification in Uruguay from 1993 to 2013. Global Food Security 9, 10-18.

Poorter H, Niklas KJ, Reich PB, Oleksyn J, Poot P \& Mommer L (2012) Biomass allocation to leaves, stems and roots: meta-analyses of interspecific variation and environmental control. New Phytologist 193, 30-50.

Pretty J, Toulmin C \& Williams S (2011) Sustainable intensification in African agriculture. International Journal of Agricultural Sustainability 9, 5-24.

Prost L, CERF M \& JeUfFroy M-H (2012) Lack of consideration for end-users during the design of agronomic models. A review. Agronomy for Sustainable Development 32, 581-594.

Rocha JM (2011) As Raízes da Crise da Metade Sul. Estudo da formação econômica do Rio Grande do Sul, (ed. Unipampa), 1 edn. Fundação Universidade Federal do Pampa, Jaguarão, RS, Brazil.

SÁ JM, URQUiaga S, JANTALIA CP et al. (2013) Energy balance for the production of grain, meat, and biofuel in specialized and mixed agrosystems. Pesquisa Agropecuária Brasileira 48, 1323-1331.

SAS InstitUTE (2016) The SAS system for Windows. Version 9.4. Cary, NC.

Silva JJC, Theisen G, Andres A, Silva JLS \& IDEhara SJ (2012) Avaliação do uso do rolofaca no preparo do solo pós-colheita do arroz irrigado em áreas da planície costeira do RS. In: Documentos, 349, Vol. 1, 28 p. Embrapa Clima Temperado, Pelotas, RS, Brazil.

Silva LSD, PocoJeski E \& RHODEN AC (2011) Mineral nitrogen dynamics after flooding in lowland soils of Rio Grande do Sul. Semina: Ciências Agrárias 32, 583-590.

SÓRIO JR. H (2001) A ciência do atraso: índices de lotação pecuária no Rio Grande do Sul. UPF (Universidade de Passo Fundo), Passo Fundo, Brazil.

SOSBAI (2014) Arroz irrigado: recomendações técnicas da pesquisa para o sul do Brasil, (ed. Sosbai), 1 edn. Sociedade Sul Brasileira de Arroz Irrigado, Santa Maria, RS, Brazil.

Tominaga LK (2009) Análise e Mapeamento de Risco. In: Desastres naturais: conhecer para prevenir, Vol. 1. (eds LK Tominaga, J Santoro \& R Amaral), 147-160. Instituto Geológico, Governo do Estado de São Paulo, São Paulo, Brazil.

US Environmental Protection Agency - EPA (2017) Models for Pesticide Risk Assessment - SCIGROW (Screening Concentration In GROund Water). Available at: https://www.epa.gov/pesticide-science-and-assessing-pesticide-risks/models-pesticiderisk-assessment\#scigrow (accessed 12 Jan 2017).

VERNETTI FdJ \& VERNETTI JR. FdJ (2013) Histórico da pesquisa de soja na região sudeste do Rio Grande do Sul: várzeas e coxilhas (do IAS à ETB), (ed. FDJ Vernetti Jr.). Embrapa Clima Temperado, Pelotas, RS, Brazil.

WitzKe HV \& NOLEPPA S (2016) The high value to society of modern agriculture: Global food security, climate protection, and preservation of the environment - evidence from the European Union. In: Frontiers of Economics and Globalization, Vol. 16. (eds Andrew Schmitz, P. Lynn Kennedy \& TG Schmitz), 55-65. Emerald Group Publishing Limited. 
Zentner R, Lafond G, Derksen D, Nagy C, Wall D \& May W (2004) Effects of tillage method and crop rotation on non-renewable energy use efficiency for a thin Black Chernozem in the Canadian Prairies. Soil and Tillage Research 77, 125-136. 



\section{Chapter 4}

\section{A knife-roller effectively substitutes soil preparation by plough-and-harrow in lowland production systems}

Article accepted to be published in Experimental Agriculture

Giovani Theisen*†; Júlio José Centeno da Silva*; Lammert Bastiaans† $\dagger$

* Embrapa Temperate Climate, BR 392, km 78, 96010-970, Pelotas, RS, Brazil

$\dagger$ Centre for Crop System Analysis, Wageningen University, Wageningen, Netherlands 


\title{
A knife-roller effectively substitutes soil preparation by plough-and-harrow in lowland production systems
}

\author{
Giovani Theisen*†; Júlio José Centeno da Silva*; Lammert Bastiaans † \\ * Embrapa Temperate Climate, BR 392, km 78, 96010-970, Pelotas, RS, Brazil \\ $\dagger$ Centre for Crop System Analysis, Wageningen University, Wageningen, Netherlands
}

\begin{abstract}
Cropping systems in lowlands of temperate South America have historically been based on irrigated rice and beef-cattle production. In the two last decades, technological improvements and the insertion of crop rotation markedly increased production levels in these areas, especially in the wetlands of south Brazil. Despite several technical advances, plough-and-harrow still is the most used method to prepare the soil after a season of irrigated rice. This technique, however, promotes high soil disturbance and is time and energy-demanding. Besides that, its application is restricted to a narrow set of weather and soil conditions, often resulting in an undesirable time gap between rice harvest and soil preparation. To improve the sustainability of a rice-soybean rotation system, we studied an alternative method for soil preparation following irrigated rice, based on a heavy knife-roller $(3.6 \mathrm{~m}$ length, diameter $1.0 \mathrm{~m}$, with 15 blades $0.13 \mathrm{~m}$ high and mass $2,860 \mathrm{~kg}$ ). The performance of this method was evaluated during three cropping seasons and compared to the traditional plough-and-harrow, by determining the establishment and productivity of soybean, as well as indicators associated to energy consumption. The experiment was conducted in Pelotas, south Brazil, in a flat hydromorphic soil. Both methods were allocated sideby-side and soil preparation was conducted after the harvest of irrigated rice, as soon as favourable conditions for the specific method were met. In the subsequent summer, soybean was seeded using a no-tillage seeder. Observations on soybean establishment and grain yield demonstrated that the alternative method based on a knife-roller performed as well as the conventional plough-based system. Benefits of the roller-based method were a 50\% reduction in energy consumption for soil preparation, corresponding to a $22 \%$ increase in overall energy use-efficiency of soybean production. Labour time and greenhouse gas emissions for soil preparation were reduced with $29 \%$ and $55 \%$, respectively. Next to these savings, the method can also be performed shortly after rice harvest, creating better opportunities for the introduction of cover crops or pastures in between rice and soybean. In conclusion, the knife-roller method showed to be a suitable alternative for seedbed preparation after irrigated rice in lowland production systems.
\end{abstract}

Keywords: crop management, irrigated rice, machinery, seedbed preparation, wetlands. 


\subsection{Introduction}

Rice is the main staple food for nearly half of the world's population and is predominantly cultivated in lowlands, where it is one of the most important crops. In Brazil, the largest rice producer outside Asia, eighty percent of the rice is produced in lowlands in the southern states of the country. In these fields, irrigated rice is cultivated in 1.2 million ha by approximately 17,000 farms, which attained an average grain yield of $7.6 \mathrm{Mg} \mathrm{ha}^{-1}$ in the 2015/16 cropping season (IBGE, 2016). Cropping systems from the southern Brazilian lowlands have historically relied on a combination of irrigated rice, cultivated in summer, and beef-cattle, which can occupy the field at any time the field is left fallow (Rocha, 2011). In the last decades, important technological changes occurred in the southern Brazilian lowlands, as the increase in area of minimum tillage over conventional tillage, the introduction of herbicide-tolerant rice cultivars, and the increase of soybean area, rotated with irrigated rice. Minimum-tillage and herbicidetolerant rice are currently present in $70 \%$ of the lowland paddies, and approximately one-third of irrigated rice is rotated with soybean, where these crops usually compose a two-year rotation scheme (IRGA, 2017).

Despite the technical benefits provided by these aforementioned advances, the sustainability of southern Brazilian paddies is still fragile, and faced with major challenges. Lowering the energy use in rice production, which requires 1.5 times more energy than upland wheat and 2.25 times more energy than soybean (Ferreira et al., 2014), is one of these tasks. Next to irrigation and fertilizers, the relatively high energy demand is connected to the requirement for soil preparation, which is originated by rice harvesting taking place under wet soil conditions. Soil preparation following a rice season is required to make a proper seedbed for the next crop seeding. These operations, which are required independently if in conventional- or minimum-tillage fields, are commonly based on plough, harrow and levelling, and are energy-demanding, intensively soil-disturbing and time-consuming (SOSBAI, 2014).

The typical plough-harrow-levelling method seldom delivers the seedbed in the proper time for winter crops, as these operations require dry soil, and in subtropical South America the period between autumn and winter is commonly rainy (Britto et al., 2006). This hurdle either affects cattle gains, since the growing of winter pastures is delayed, and also reduces the chances of establishing a winter cover crop meant for soil amelioration. In this way, typical conservation agriculture (CA)-associated techniques, such as the quick establishment of a living mulch layer by cover crops or pastures and the absence of soil disturbance, are hardly successful in the lowlands. In some years, soil preparation is delayed to such an extent that farmers cannot 
even seed the next summer crop at the proper time, despite the long interval since the previous rice harvest. Clearly, a more robust soil preparation method, less reliant on weather conditions, would favor the lowland's cropping systems.

Roller-based equipment, like knife-rollers (Figure 1), crimper rollers and rotovators, has been used for soil preparation in several regions across the world. A number of distinct functions and attributes have been reported for rollers, like seedbed preparation (Jia et al., 2016); increase seed-soil contact (Sadeghpour et al., 2015); breaking of soil clods (Wolf \& Luth, 1979); soil levelling in rice paddies (Zhang et al., 2016); management of insect-pests (Jiang et al., 2011), weeds and their seedbank (Chaudhari et al., 2012; Massoni et al., 2013), cover crops (Kornecki, 2015); and stubble management, to accelerate decomposition (Botta et al., 2015) and to facilitate the seeding of the next crop (Singh et al., 2006). The potential benefits from using roller-based tillage after irrigated rice advance beyond its inherent logistic advantages. A knife-roller operation commonly requires less fuel and draught power if compared to rotovators or plough-and-harrow operations (Pimentel, 1992). Knife-rollers can incorporate rice stubbles near to the soil surface, which, compared to deep incorporation, reduces the amount of methane from residue decomposition (Alberto et al., 2015). The shallow soil preparation inherent to rollers also protects the soil hardpan from disruption, thereby preventing water losses through percolation in the rice paddies (Janssen \& Lennartz, 2007). Finally, as the method requires standing water in the field, it is possible to apply a knife-roller passage shortly after rice harvest. Standing water is required, since it allows the soil to be shaped by the weight of the equipment and to reduce the adherence of the soil to the machinery. The advantage of early soil preparation, which is not possible with the conventional method simply because the soil is still too wet for this practice, is the creation of a good opportunity for the establishment of winter pastures or cover crops (Silva et al., 2012) This in turn supports crop diversification and a higher production of biomass in the cropping system. A passage of a kniferoller levels the soil and will not completely eliminate compaction resulting from harvesting operations and the tractor pulling the roller. However, this is not a major problem, as the kniferoller method minimizes the frequency of soil disturbance and the instalment of cover crops, particularly grasses, helps to improve the soil structure in the long run.

Roller-based methods are rarely described as the unique tool used for soil preparation in rice paddies (an exception is found in Valsesia et al. (2009)). In the current research we evaluated the performance of a knife-roller preparing the soil after the harvest of irrigated rice. The roller-based technique was compared to the plough-and-harrow method, in a cropping 
system in which irrigated rice is rotated with soybean. Besides evaluating time- and energyrequirement, the quality of the seedbed was evaluated based on soybean seedling establishment, uniformity and productivity. Our hypothesis is that if the roller produces similar agronomic results as the plough-based tillage, the efficiency of the overall cropping system is increased, since the knife-roller demands less energy to prepare the soil than the traditional method. The novelty of this research is that the knife-roller was used as the only form of soil preparation in a typical flat lowland field after irrigated rice.

\subsection{Material and methods}

\section{Initial field preparation}

This study was conducted during the cropping seasons 2011, 2012 and 2013 in the Lowlands Experimental Station (LES) of Embrapa, Pelotas, south Brazil (31.8134 S; 52.4736 W). The terrain is flat ( $0 \%$ slope), at $13 \mathrm{~m}$ above sea level, and the soil is classified as Solodic haplic eutrophic Planosol (Streck et al., 2008), with a hard pan $40-50 \mathrm{~cm}$ below soil surface. Soil bulk density was $1.33 \mathrm{~kg} \mathrm{dm}^{-3}$, with $15.9 \mathrm{~g} \mathrm{dm}^{-3}$ organic matter, $266 \mathrm{~g} \mathrm{dm}^{-3}$ clay, $493 \mathrm{~g} \mathrm{dm}^{-3}$ silt and $552 \mathrm{~g} \mathrm{dm}^{-3}$ sand. The climate is characterized as humid temperate (Cfa, according to Köppen's classification), with an average temperature of $17.8^{\circ} \mathrm{C}$ and yearly precipitation of $1370 \mathrm{~mm}$.

A uniform paddy field of 2.7 ha was cultivated with irrigated rice in mid-November 2010, dry-seeded with a no-tillage seeder, in rows $17.5 \mathrm{~cm}$ apart. A short-cycle, long-grain variety was used (BRS Querência, with 110 days to maturation). Management for pest control and plant nutrition followed the regional recommendations for irrigated rice (SOSBAI, 2014). Irrigation started three weeks after rice emergence and an $8 \mathrm{~cm}$ water layer was maintained until physiological maturity. Rice was harvested with a commercial combine harvester equipped with rubber tyres, approximately 120 days after emergence. At harvest, the water still formed a narrow layer of 0.5 to $2 \mathrm{~cm}$ on the soil surface. The harvest operations resulted in extensive soil disturbance, with machinery tracks measuring an average depth of $30 \mathrm{~cm}$. Following this initial rice cultivation, the field was divided in two parts: one received the experiment and was cultivated with soybean in the next summer, starting a yearly soybean-rice rotation. The other half was for the second year cultivated with rice, and the rotation with soybean started only in the next season. In this way, the experimental field always had a plot available to receive the treatments after rice harvest. 


\section{Description of treatments}

Two treatments for soil tillage after rice harvest were compared, consisting of the traditional plough and harrow system, and the alternative knife-roller tillage system. Each treatment was applied in three plots of $6 \mathrm{~m} \times 30 \mathrm{~m}$, with breaks of $5 \mathrm{~m}$ in between to facilitate machinery operations. Residues remaining on the soil surface were $6.3,5.9$ and $6.7 \mathrm{Mg}$ dry matter ha ${ }^{-1}$ for the cropping seasons 2011, 2012 and 2013, respectively. Tillage with the knife-roller was always performed in the first week after rice harvest. As the plough and harrow requires dry soil this operation was conducted later, up to 45 days after rice harvest. The essential characteristics of both soil preparation systems are:

Plough and Harrow: the primary tillage after rice harvest used a common five-piece mouldboard plough, inverting the soil and incorporating the rice straw at an average depth of $0.4 \mathrm{~m}$. The secondary tillage was performed between one to two weeks after the mouldboard plough, using a heavy 26"-disk harrow (diameter $66 \mathrm{~cm}$ ) with 26 disks operating at a depth of $0.3 \mathrm{~m}$, followed by a double-pass of a light 20"-disk harrow (diameter $51 \mathrm{~cm}$ ) with 28 disks operating at a depth of $0.1 \mathrm{~m}$. In the third cropping season, a large 28 "-disk plough (diameter $71 \mathrm{~cm}$ ) with 3 disks operating at $0.3 \mathrm{~m}$ depth substituted the mouldboard plough and only one pass of the light harrow was applied.

Knife-roller system: the knife-roller consisted of a hollow steel drum of $3.6 \mathrm{~m}$ length, a diameter of 1.0 m equipped with 15 sharp blades of $0.13 \mathrm{~m}$ high. The steel drum was partially filled with water and the operational weight was $2,860 \mathrm{~kg}$. A tractor pulled the roller, which, through its weight, levelled the soil and partially incorporated rice straw up to $0.13 \mathrm{~m}$ deep. Since free water on the soil surface is required for this equipment - to improve soil levelling, avoid the adherence of soil to the roller and reduce the depth of tractor tracks - the levees in the perimeter of the plots were re-constructed after rice harvest, using a levee-plow. At moment of rolling, a layer of $2 \mathrm{~cm}$ of water remained in the field. Two passes with the knife-roller were applied in each plot to create a uniform soil levelling. Figure 1 illustrates the soil adjustment created by the knife-roller.

After finishing a tillage treatment, a series of drainage channels were created with a narrow rotary trencher. The channels were spaced at $20 \mathrm{~m}$, were $0.15 \mathrm{~m}$ wide and around 0.30 $\mathrm{m}$ deep. The soil was maintained dry during the cold season (April to October). In the succeeding summer, a medium-cycle soybean (cv. BRS 246-RR) was seeded and the drainage channels were re-made. Commercial S2-class soybean seeds with a germination rate of $80 \%$ 
were used. For all cropping seasons, the soybean was seeded in the second week of November with a no-tillage seeder in rows $44 \mathrm{~cm}$ apart, at a seeding rate of $70 \mathrm{~kg} \mathrm{ha}^{-1}$ (2011) and $60 \mathrm{~kg}$ $\mathrm{ha}^{-1}$ (2012 and 2013). All soybean management followed the official regional recommendations.

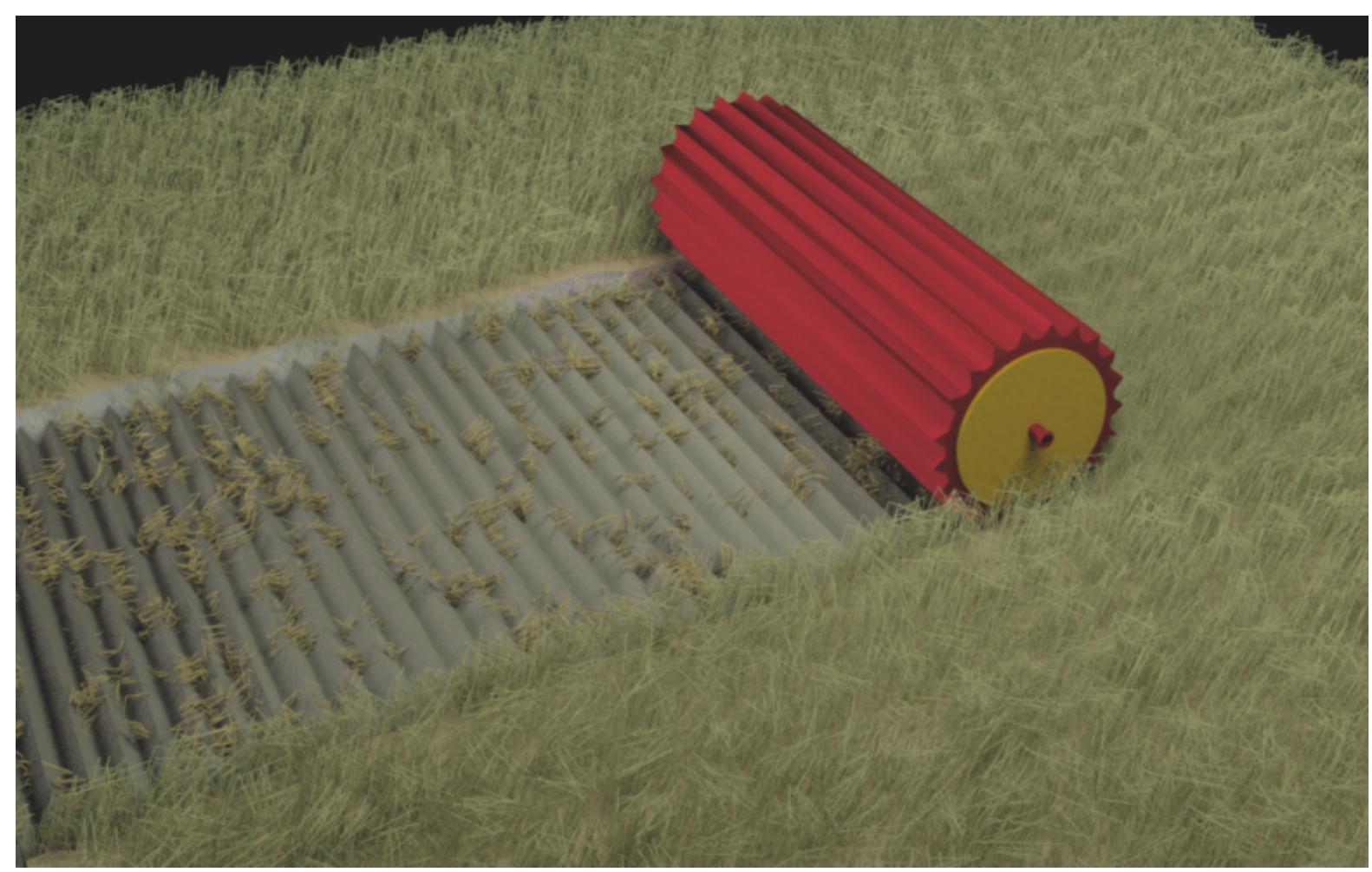

Figure 1. Representation of a knife roller operating in a post-harvest, watered rice field. Additional parts of equipment are not included in the image. Roller promotes shallow rice straw incorporation, levels the soil and creates uniform depressions in the soil. Drawing made by the author using the software Blender 3D v2.78.

\section{Energy cost, energy balance and greenhouse gas (GHG) emissions}

The description of the machinery, their weight, operational yield, average fuel consumption, embodied energy and total energy consumption is presented in Table 1. Operational yield (h $\mathrm{ha}^{-1}$ ) and fuel consumption ( $\mathrm{L}$ diesel oil ha $\mathrm{ha}^{-1}$ ) were both recorded during the execution of the experiment. Embodied energy represents the energy consumed to build the machinery, distributed over the machines normal life span. Embodied energy of machinery and the depreciation over time was calculated using procedures described by Pimentel (1992). In the table, embodied energy is expressed on a per unit area basis $\left(\mathrm{MJ} \mathrm{ha}^{-1}\right)$, based on the empirically determined operational yield for the machinery. Next to the regular energy consumed for field operation in Table 1, an extra energy of $216 \mathrm{MJ}$ and an extra GHG emission of $13.1 \mathrm{~kg} \mathrm{CO}_{2}$-e 
were attributed to the knife-roller treatment and included in the further analysis. These values are equivalent to a five-day extension of the irrigation period in order to guarantee a proper amount of standing water on the soil surface. For this addition, the energy consumed by the electro-mechanical irrigation system was calculated from the regional values reported by IRGA (2014).

The energy equivalent from the inputs and from soybean grains, as well as the reference from which this information was retrieved, are described in Table 1. To estimate the total energy costs and GHG emissions, the amount and type of nutrients and pesticides used in soybean were recorded for each cropping season. Greenhouse gas emissions were reported in $\mathrm{CO}_{2}$-e units. Values used were $3.368 \mathrm{~kg} \mathrm{CO}_{2}$-e L $\mathrm{L}^{-1}$ for diesel $\left(2.966 \mathrm{~kg} \mathrm{CO}_{2}\right.$-e from combustion (IPCC, $2006)+0.320 \mathrm{~kg} \mathrm{CO}_{2}$-e from production (Carvalho, 2012) + $0.082 \mathrm{~kg} \mathrm{CO}_{2}$-e from transports (Eriksson \& Ahlgren, 2013), $5.15 \mathrm{~kg} \mathrm{CO}_{2}-\mathrm{e} \mathrm{kg}^{-1}$ for urea, $2.03 \mathrm{~kg} \mathrm{CO}_{2}-\mathrm{e} \mathrm{kg}^{-1}$ for di-ammoniumphosphate, $0.27 \mathrm{~kg} \mathrm{CO}_{2}-\mathrm{e} \mathrm{kg}^{-1}$ for super triple phosphate, $0.25 \mathrm{~kg} \mathrm{CO}_{2}$-e kg-1 for chloride of potassium (Fertilizers Europe, 2014). For pesticides, an emission of $0.069 \mathrm{~kg} \mathrm{CO}_{2}$-e per MJ required to process $1 \mathrm{~kg}$ a.i. was assumed, using values of 374,344 and $278 \mathrm{MJ} \mathrm{kg}^{-1}$ a.i. for herbicides, fungicides and insecticides, respectively (Saunders et al., 2006). The GHG emissions related to soybean seeding material (seed production, processing, packaging and transport) were estimated according to Heichel (1980), and assumed as $0.98 \mathrm{~kg} \mathrm{CO}$-e per $\mathrm{kg}$ of seed.

\section{Data collection}

Soybean was sampled to evaluate plant density (at V4 and R8 growth stages) and grain yield (at R8). Each sample consisted of two rows of soybean, located side-by-side with a length of 5 m. Four (2011 and 2012 cropping seasons) and five (2013 cropping season) two-row samples were taken in each plot. At V4, the soybean plants were counted in the field. At R8, the plants were pulled out, counted and then threshed in an electrical threshing machine to evaluate grain yield. Grain moisture was evaluated in an automatic analyser and the yield was standardized to $13 \%$ moisture. 
Table 1. List and characteristics of machinery and inputs used in the field operations.

\begin{tabular}{lccccc}
\hline \multicolumn{1}{c}{ Machinery } & $\begin{array}{c}\text { Weight } \\
(\mathrm{kg})\end{array}$ & $\begin{array}{c}\text { Operational } \\
\text { yield } \\
\left(\mathrm{h} \mathrm{ha}^{-1}\right)\end{array}$ & $\begin{array}{c}\text { Fuel } \\
\text { consumption } \\
\left(\mathrm{L} \mathrm{ha}^{-1}\right)^{\mathrm{a}}\end{array}$ & $\begin{array}{c}\text { Embodied } \\
\text { energy } \\
\left(\mathrm{MJ} \mathrm{ha}^{-1}\right)\end{array}$ & $\begin{array}{c}\text { Energy } \\
\text { consumption } \\
\left(\mathrm{MJ} \mathrm{ha}^{-1}\right)^{\mathrm{b}}\end{array}$ \\
\hline Tractor 89 kW & 4650 & - & - & 35.6 & - \\
Tractor 55.2 kW & 2564 & - & - & 20.0 & - \\
Moldboard plough (0.4 m depth) & 1369 & 1.43 & 25.7 & 50.0 & 1245 \\
Disc plough (0.3 m depth) & 410 & 1.41 & 23.2 & 14.8 & 1099 \\
Heavy disc harrow (0.3 m depth) & 2247 & 1.33 & 21.2 & 98.3 & 1095 \\
Light disc harrow (0.1 m depth) & 760 & 1.00 & 12.0 & 24.2 & 594 \\
Levee plow & 500 & 0.81 & 11.2 & 25.5 & 552 \\
Rotary trencher (0.15 m width) & 385 & 1.00 & 11.0 & 9.8 & 535 \\
Knife-roller (empty) & 1520 & 0.57 & 5.7 & 24.3 & 299 \\
No-tillage seeder & 2540 & 1.05 & 13.3 & 83.0 & 711 \\
Pesticide sprayer 600 L & 450 & 1.00 & 8.0 & 8.9 & 385 \\
Grain harvester & 9100 & 0.91 & 25.5 & 109.4 & 1242 \\
\hline
\end{tabular}

\begin{tabular}{|c|c|c|}
\hline Inputs & Energy equivalent & Reference \\
\hline Diesel fuel & $44.5 \mathrm{MJ} \mathrm{L}^{-1 \mathrm{c}}$ & Eriksson and Ahlgren (2013) \\
\hline Soybean grain & 16.7 $\mathrm{MJ} \mathrm{kg}^{-1}$ & García et al. (2014) \\
\hline Soybean seeds ${ }^{\mathrm{d}}$ & $32.4 \mathrm{MJ} \mathrm{kg}^{-1}$ & García et al. (2014) \\
\hline Human average farming work & $2.16 \mathrm{MJ} \mathrm{h}^{-1}$ & Medeiros (2011) \\
\hline $\mathrm{N}_{2}$ & $63.4 \mathrm{MJ} \mathrm{kg}^{-1}$ & Patzek (2004) \\
\hline $\mathrm{P}_{2} \mathrm{O}_{5}$ & 17.4 $\mathrm{MJ} \mathrm{kg}^{-1}$ & Pimentel (2003) \\
\hline $\mathrm{K}_{2} \mathrm{O}$ & $13.8 \mathrm{MJ} \mathrm{kg}^{-1}$ & Pimentel (2003) \\
\hline Herbicides & $374 \mathrm{MJ}(\mathrm{kg} \text { a.i. })^{-1}$ & Saunders et al. (2006) \\
\hline Fungicides & $344 \mathrm{MJ}$ (kg a.i. $)^{-1}$ & Saunders et al. (2006) \\
\hline Insecticides & $278 \mathrm{MJ}(\mathrm{kg} \text { a.i. })^{-1}$ & Saunders et al. (2006) \\
\hline Mineral oil as adjuvant & $44.5 \mathrm{MJ} \mathrm{L}^{-1} \mathrm{a}$ & Eriksson and Ahlgren (2013) \\
\hline
\end{tabular}

a. Diesel oil.

b. Included energetic content of fuel consumed in each operation and energy embodied in the equipment. Extra $4.5 \%$ added in account of lubricants and greases. Energy related to human labour is not included.

c. Value from Lower Heat Value (LHV) of fuels, plus extra $24 \%$, added for distribution costs (averaged from Eriksson and Ahlgren (2013)).

d. The energy content of certified soybean seeds used was 2 times the energy contained in the whole grains.

The variables used to compare both soil preparation methods were: a) soybean plant density (plants ha ${ }^{-1}$ ) at V4 and R8; b) soybean grain yield $\left(\mathrm{kg} \mathrm{ha}^{-1}\right)$; c) total energy consumption $\left(\mathrm{MJ} \mathrm{ha}^{-1}\right)$ from soil preparation to soybean harvest; d) energy used for soil preparation (MJ ha${ }^{1}$ ); e) GHG emitted ( $\left.\mathrm{kg} \mathrm{CO}_{2}-\mathrm{e} \mathrm{ha}^{-1}\right)$ from soil preparation to soybean harvest; f) GHG emitted by the machinery in soil preparation $\left(\mathrm{kg} \mathrm{CO}_{2}-\mathrm{e} \mathrm{ha}^{-1}\right)$; e) energy balance ( $\left.\mathrm{GJ}^{\mathrm{h}} \mathrm{ha}^{-1}\right)$; f) Energy Return on Energy Invested $\left(\mathrm{MJ}_{\text {in }} \mathrm{MJ}_{\text {out }}{ }^{-1}\right)$, representing how efficiently the energy from the inputs was converted into soybean grain energy; g) yield-scaled energy demand $\left(\mathrm{MJ}_{\text {in }} \mathrm{Mg}\right.$ soybean $^{-1}$ ), representing the energetic cost to produce $1000 \mathrm{~kg}$ of soybean; h) time required for soil preparation $\left(\mathrm{h} \mathrm{ha}^{-1}\right)$; i) amount of soybean produced per $\mathrm{kg} \mathrm{CO}_{2}$-e emitted. 


\section{Statistical Analysis}

The experiment was carried out as a randomized complete block design, with three replications per treatment in each cropping season. Data were tested for normality assumption using the Shapiro-Wilk test provided by the Proc Univariate in SAS software version 9.4 (SAS Institute, 2016). No data transformation was needed. Analysis of variance was applied to data and tillage treatments compared by F test. Variability of soybean density and grain yield was evaluated by the Levene's test, with an additional aid of the graphical diagnostics provided by the option "plot=diagnostics" in the GLM procedure in SAS software. Data is presented as means and their respective standard errors (SEM).

\subsection{Results and discussion}

The conventional method of soil preparation after rice harvest is based on plough, harrow and levelling operations. This technology promotes intense soil disturbance and requires, preferably, a dry soil to be performed. As the lowland soils are easy to wet but present a slow drying, farmers dependent on conventional soil preparation often have no other option than to leave the field fallow after rice harvest. This is particularly true for rainy winters, which are frequent in south Brazil. In some cases, soil preparation to make the field ready for seeding the next crop might have to be postponed till next spring. From this perspective, the versatility of the knife-roller based method is striking. The equipment is operated with water on the soil surface, and the paddy can be prepared immediately after rice harvest, or during rainy periods. As the method is less dependent on specific conditions of soil and weather, it takes less time than the conventional methods (plough \& harrow- based) before the field is ready for the next cultivation. The fast readiness for field preparation after irrigated rice is an important factor for the efficiency of farms practicing crop rotation or crop-livestock integration in lowlands (Silva et al., 2012).

\section{Technical results on soybean}

Rice-soybean rotation is used in several lowland cropping systems in the world. Constraints associated to residue management and seedbed formation are a well-known difficulty of these hydromorphic soils (Garrity et al., 1990). Soybean requires an efficient soil drainage system and an adequate seedbed formation to attaining high rates of seed germination, adequate seedling survival, a uniform plant stand and high growth rates during the early stages of development (Wuebker et al., 2001). The current experiment showed that both methods for soil 
preparation were effective in preparing an appropriate seedbed for soybean seeding and germination. In none of the three cropping seasons we found significant differences in soybean population ( $p>0.43$ ) between Plough and Harrow and the alternative Knife Roller system, either at the initial stage (V4) or at soybean maturity (R8) (Figure 2-A). On average, final soybean density was according to the recommended population for the crop in south Brazil $(240,000-$ 360,000 plants $\mathrm{ha}^{-1}$ ). In the first cropping season, the population was approximately 30,000 plants ha ${ }^{-1}$ higher than in the last two seasons (Figure 2-A), following the difference in seeding rates between $2011\left(70 \mathrm{~kg} \mathrm{ha}^{-1}\right)$ and 2012 and $2013\left(60 \mathrm{~kg} \mathrm{ha}^{-1}\right)$.

For both treatments soybean density at R8 was slightly inferior to the density observed at V4 (Figure 2-A). This result is not a surprise, since a minor adjustment due to self-thinning is normally observed as the crop develops towards maturity. In the experiment, some plants also got lost because of temporary flooding, which occurred in parts of the field after the rains. These flooded spots, which are common for lowland paddies, were observed in both soil preparation methods and coincided with small depressions dispersed over the terrain surface, with an individual area no larger than $0.3 \mathrm{~m}^{2}$.

Similar to soybean density, the methods used to prepare the soil after irrigated rice did also not influence soybean grain yield. In the first cropping season, an apparent gain in favour of Plough and Harrow was perceived, whereas in the last season, a difference in favour of the alternative Knife Roller system was observed (Figure 2-B). These differences, however, were not significant $(p>0.05)$. Additional to the comparison between yield averages, we examined the data on plant density and grain yield from the variability perspective, since establishing a uniform plant population is one of the key factors for enabling a high yield potential for soybean (Tourino et al., 2002). Variability of plant density and grain yield was similar for both treatments $(p>0.05$; according to Levene's test). This result reinforces the evidence that the roller-based method, from an agronomic perspective, has a potential to produce similar results as the traditional plough-and-harrow system on seedbed preparation following irrigated rice.

\section{Energy consumption and greenhouse gas emissions}

The energy consumed to cultivate soybean ranged from 11.7 to $14.3 \mathrm{GJ} \mathrm{ha}^{-1}$ per cropping season (data from Figure 3-A). These values are higher than the energetic cost reported by Ferreira et al. (2014) in Brazil (around 7.5 GJ ha' ${ }^{-1}$ ), but lower than the costs described by Hamzei and Seyyedi (2016) in Iran (27.8 to $31.8 \mathrm{GJ} \mathrm{ha}^{-1}$ ). Regardless of such differences, our data visibly revealed the distinction between both soil preparation methods from the energy perspective. 
Energy costs were reduced with $18 \%$ when the soil was prepared with the knife-roller. This difference could be largely attributed to soil preparation, which made up 32\% and 19\% of all energy required, for the Plough and Harrow and the Knife-Roller methods, respectively. The conventional system, based on plough and harrow, required two times more energy to prepare the soil than the alternative method based on the knife-roller (Figure 3-A).
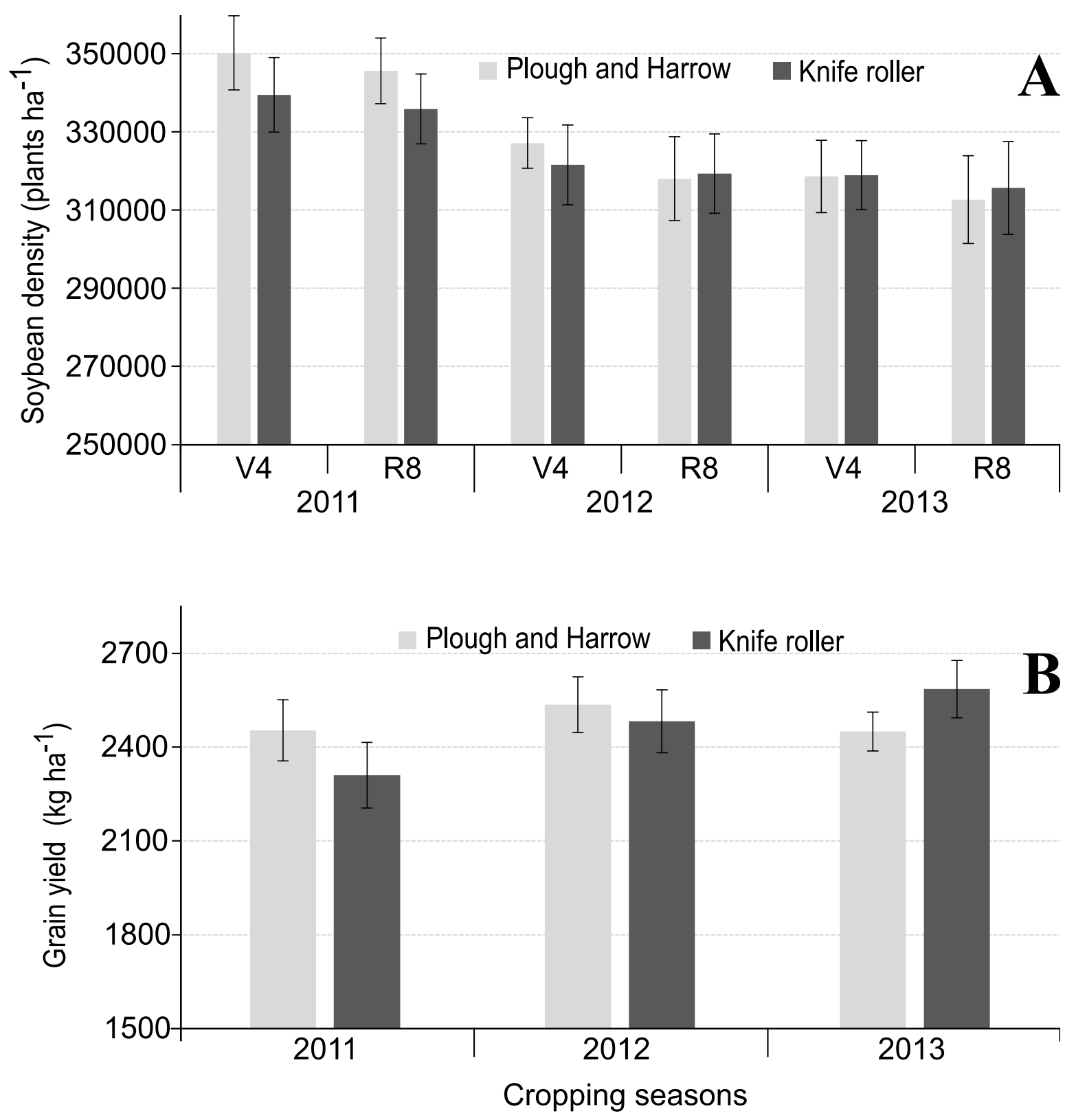

Figure 2. Influence of two soil preparation methods (plough-and-harrow, grey columns; kniferoller, dark columns) on soybean plant density (A) at two growing stages (V4 and R8) and grain yield (B), in three cropping seasons. Bars represent the standard error of means. Within a cropping season, the differences between soil preparation methods were not significant for any of the measured characteristics $(p>0.05)$. 

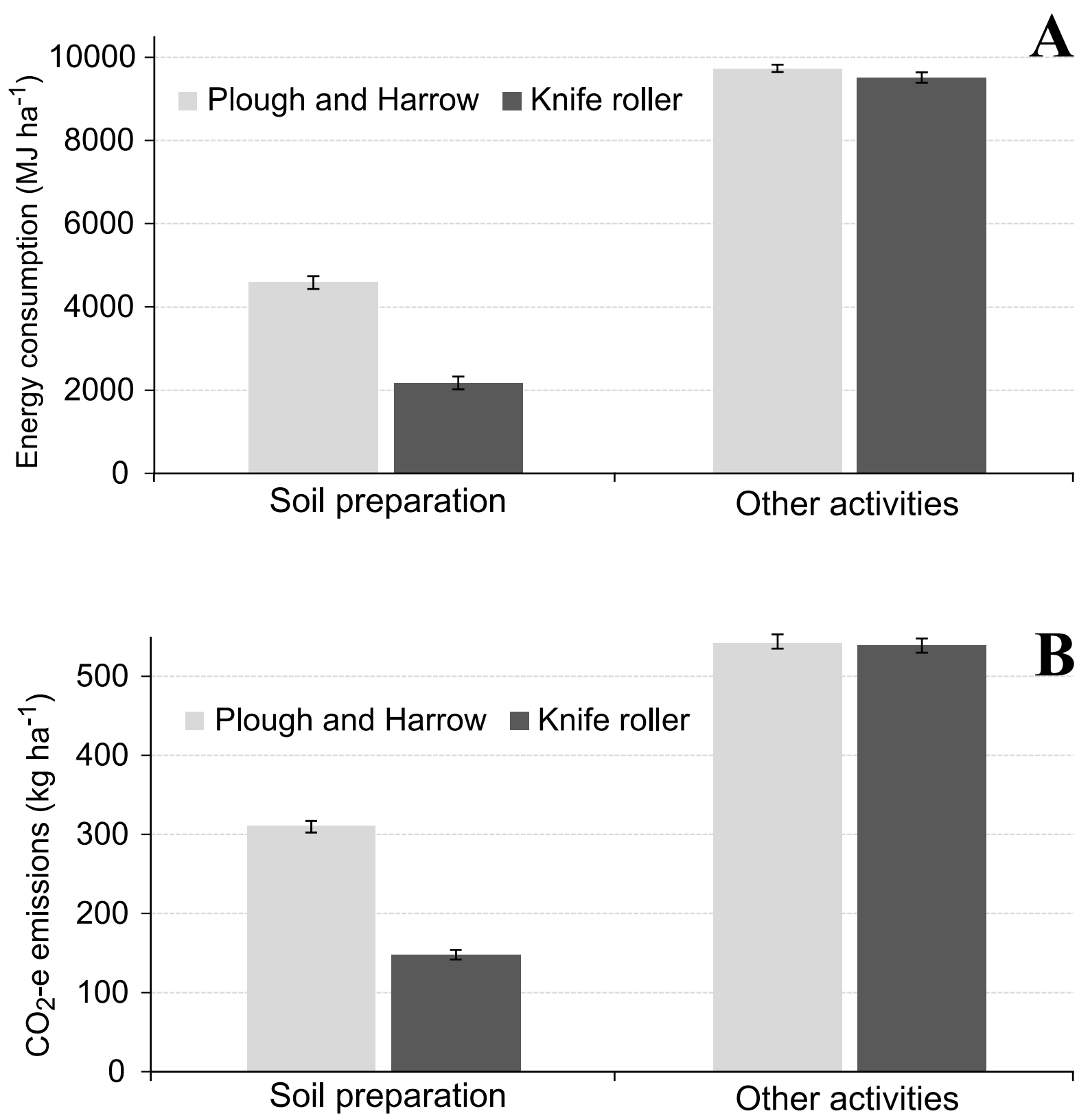

Figure 3. Energy consumed (A) and greenhouse gas emitted (B) related to soil preparation and other activities in soybean production using either plough-and-harrow (grey columns) or kniferoller (dark columns) as soil preparation method. Data averaged over three cropping seasons. Bars represent the standard error of mean.

Greenhouse gas emission (Figure 3-B) followed a similar trend as observed for energy consumption. Cropping soybean under the traditional plough and harrow method emitted 140 $\mathrm{kg} \mathrm{CO}_{2}$-e ha ${ }^{-1}$ more than under the alternative knife-roller based method. A high correlation between energy consumption and GHG emissions is expected, since most of the energy used in soybean production originates from fossil fuels, which are an important source of greenhouse gas emissions. Similar to what was mentioned above, these differences between both tillage 
methods largely originated from the distinct amounts of fuel used for soil preparation. While the quantity of diesel fuel used in the alternative system in soil preparation was about $45 \mathrm{~L} \mathrm{ha}^{-}$ ${ }^{1}$ (from a total of $132.9 \mathrm{~L} \mathrm{ha}^{-1}$ ) per cropping season, the conventional system consumed on average $94 \mathrm{~L} \mathrm{ha}^{-1}$ (of $182.6 \mathrm{~L} \mathrm{ha}^{-1}$ ).

Different from the agronomic characteristics (plant density and grain yield), the indicators related to energy, labour time and greenhouse gas emissions pointed at important differences between the soil preparation systems (Table 2). The energy balance, which indicates the energy represented in soybean grains after discounting for all energy used in production, was 9\% larger in the Knife Roller method. Energy Return on Energy Invested, which represents the net energy produced by each unit of energy put in the system, improved with $22 \%$ when the alternative method was used. In the same way, the yield-scaled energy demand, which represents how much energy was required to produce $1 \mathrm{Mg}$ of soybean, was more favourable with the Knife Roller method. Energy savings of $20 \%$ per ton of soybean grains produced were obtained by using the alternative method of soil preparation.

Since the soybean grain yield was similar between the two soil preparation methods, but the energy consumed and the GHG emissions were distinct, the results found for the integrated indicators combining these aspects were not a surprise. For instance, the indicators Energy Return on Energy Invested, Yield-scaled energy demand, and soybean produced per $\mathrm{kg} \mathrm{CO}_{2}$-e emitted, all revealed the superiority of the alternative method. These indicators consistently showed an average advantage of around $22 \%$ of the new system over the conventional ploughand-harrow method. Such differences are highly relevant. Agricultural improvements on energy use and GHG emissions, as reported here, are required to meet international targets regarding agriculture and global warming (Blandford \& Josling, 2009), and also provide incentives for local farmers toward a more sustainable agriculture, congruent with the "Low-CarbonAgriculture" program in Brazil (Brasil, 2012).

Using the knife roller system instead of the traditional method for soil preparation saved $29 \%$ in labour time. The relatively high speed that can be used with the alternative method and the reduced number of passes (just two, whilst the conventional system requires three to four passes) are responsible for this difference. The last indicator, which related greenhouse gas emissions to soybean production, was also in favour of the alternative, roller-based soil preparation. In this case, the knife-roller system produced $0.66 \mathrm{~kg}$ more soybean per unit of $\mathrm{CO}_{2}$-e emitted than the traditional method of soil preparation, which corresponds to a $23 \%$ increase. 
Table 2. Indicators related to energy, labour time and greenhouse gas emissions in soybean cultivated in lowland fields, which were submitted to two distinct forms of soil preparation following irrigated rice in the previous cropping season.

\begin{tabular}{|c|c|c|}
\hline \multirow{2}{*}{ Indicators } & \multicolumn{2}{|c|}{ Soil preparation method } \\
\hline & Plough and Harrow & Knife-roller \\
\hline Energy balance (GJ ha $\left.{ }^{-1}\right)$ & $27.021(0.71) *$ & $29.544(1.10)$ \\
\hline Energy Return on Energy Invested (en. out en. in ${ }^{-1}$ ) & $2.89(0.05) * *$ & $3.53(0.10)$ \\
\hline Yield-scaled energy demand $\left(\mathrm{MJ}_{\text {in }} \mathrm{Mg}\right.$ soybean $\left.{ }^{-1}\right)$ & $5.85(0.11) * *$ & $4.87(0.13)$ \\
\hline Hours of work for soil preparation $\left(\mathrm{h} \mathrm{ha}^{-1}\right)$ & $10.1(0.13) * *$ & $7.2(0.1)$ \\
\hline $\mathrm{Kg}$ soybean produced per $\mathrm{kg} \mathrm{CO}_{2}$-e emitted & $2.85(0.06) * *$ & $3.51(0.08)$ \\
\hline
\end{tabular}

The differences between tillage systems are significant at levels of $p<0.05\left(^{*}\right)$ and $p<0.001(* *)$.

Values between parentheses are the standard error of mean.

\section{Evidence for further benefits from the roller-based system}

Frequency and intensity of soil preparation are the most important factors influencing soil quality in lowlands, and these factors affect especially soil bulk density (Lima et al., 2009). The roller-based method, in this perspective, is a step towards the improvement of soil quality, since the system disturbs the soil less frequently if compared to the conventional method. We speculate that the roller system can provide additional benefits in another way: as the field is prepared earlier than with the conventional method, the establishment of pastures is anticipated and the system produces a larger amount of biomass during winter time. In this situation, livestock will have access to more food, in a period which is normally restrictive for cattle in the lowlands of south Brazil, due the shortage of pastures (De Moraes et al., 2014). Additionally, the deposition of manure and the biomass remaining from pastures can increase soil quality in these integrated crop-livestock systems (Assmann et al., 2015).

Economic indicators were not the main focus of the present work; however, some considerations are relevant in this context. Our records pointed out that the roller-based method reduced the total amount of fuel used to produce soybean by almost $50 \mathrm{~L} \mathrm{ha}^{-1}$. Such savings represent an economic gain of $27 \%$ on fuels, which were derived through a reduced number of soil operations combined with the less energy demanding nature of these operations. In parallel, consistent reductions in the expenses related to labour are inferred from the roller-based method, since the system reduced the time required for soil preparation with almost three hours per hectare, if compared to the conventional method. A lower number of hours on labour can also reduce the economic depreciation of machinery, since all fieldwork is conducted using machines. In this specific case, benefits in the order of $28 \%$ are expected for machinery 
depreciation. These aspects are important and reflect some additional advantages evidenced by the roller system. In the long run, these benefits can represent stable savings to the benefit of the farm profitability.

\section{Final remarks}

In the southern Brazilian lowlands, large programs to increase rice yield were successfully implemented in the last years. Increase the grain yield per unit of land was, and still is, a priority for most farmers, suppliers and scientists. In most fields, however, such increases are largely based on a higher energy use (e.g. more fertilizers, more pesticides, and intensive soil preparation). In our view, and in line with Bennetzen et al. (2016), a sustainable, modern cropping system should neither be myopic regarding energy-efficiency issues, nor depend on solutions which are far too complex for the farmers to accomplish. The current research demonstrates that increasing the efficiency of lowland cropping systems can be obtained through relatively simple measures, as the knife-roller based method. From a practical point of view, that is what matters: a fast and easy way to prepare the soil was identified, and the method is suitable for one of the most important rotation schemes used in lowlands at a regional level. The use of this technique can obviously present different results under other conditions, but we are convinced that the roller-based method, by its inherent simplicity and easiness, can be tested and successfully used in other lowland farming systems.

\subsection{Conclusions}

In this research, the performance of a heavy knife-roller to prepare the soil in a typical hydromorphic lowland soil was evaluated. The equipment was operated in a watered field soon after mechanical rice harvest, and the method was compared to a conventional plough-andharrow soil preparation system. Both methods for soil preparation adequately level the soil and prepare an acceptable seedbed for soybean cultivation in the next summer season. Population uniformity and plant density at V4 and R8 soybean growth stages, as well as soybean grain yield, were similar between both methods. The roller-based method, however, requires less energy and is faster than the conventional system. Indicators integrating energy, grain production and greenhouse gas emissions confirm that the alternative technique, besides its inherent logistic advantages, offers a smart and sustainable option for soil preparation in lowland cropping systems. 


\subsection{Acknowledgments}

The authors express their gratitude to the staff from the Embrapa Clima Temperado and to the Eng. Agronomists Marcus Fipke and Joice Fernanda Lübke Bonow for their field assistance. This work was funded by the Brazilian Agricultural Research Corporation (Embrapa). The authors declare there is no conflict of interests regarding this research.

\subsection{References}

Alberto MCR, WASSMANN R, GUMMERT M et al. (2015) Straw incorporated after mechanized harvesting of irrigated rice affects net emissions of $\mathrm{CH}_{4}$ and $\mathrm{CO}_{2}$ based on eddy covariance measurements. Field Crops Research 184, 162-175.

ASSMANN JM, ANGHINONI I, MARTINS AP et al. (2015) Carbon and nitrogen cycling in an integrated soybean-beef cattle production system under different grazing intensities. Pesquisa Agropecuária Brasileira 50, 967-978.

Bennetzen EH, SMith P \& PorTER JR (2016) Decoupling of greenhouse gas emissions from global agricultural production: 1970-2050. Global Change Biology 22, 763-781.

Blandford D \& Josling T (2009) Greenhouse Gas Reduction Policies and Agriculture: Implications for Production Incentives and International Trade Disciplines. In: ICTSD IPC Platform on Climate Change, Agriculture and Trade. International Centre for Trade and Sustainable Development (Geneva) and International Food \& Agricultural Trade Policy Council (Washington DC), Geneva.

Botta GF, Tolón-Becerra A, Lastra-Bravo X, Hidalgo R, Rivero D \& Agnes D (2015) Alternatives for handling rice (Oryza sativa L.) straw to favor its decomposition in direct sowing systems and their incidence on soil compaction. Geoderma 239-240, 213-222.

BRASIL (2012) Plano setorial de mitigação e de adaptação às mudanças climáticas para a consolidação de uma economia de baixa emissão de carbono na agricultura: plano ABC (Agricultura de Baixa Emissão de Carbono). Vol. 1. (ed Ministério Da Agricultura Pecuária E Abastecimento), 173p. MAPA/ACS, Brasília, Brasil.

BRITTO FP, BARLETTA R \& MENDONÇA M (2006) Regionalização sazonal e mensal da precipitação pluvial máxima no estado do Rio Grande do Sul. Revista Brasileira de Climatologia 02, 35-51.

CARVAlHo PTD (2012) Balanço de emissões de gases de efeito estufa de biodiesel produzido a partir de soja e dendê no Brasil. Master, Universidade Federal do Rio de Janeiro, Rio de Janeiro, Brazil.

Chaudhari S, Sellers BA, Rockwood SV, Ferrell JA, MacDonald GE \& Kenworthy KE (2012) Nonchemical methods for paragrass (Urochloa mutica) control. Invasive Plant Science and Management 5, 20-26.

De Moraes A, Carvalho PCDF, Anghinoni I, Lustosa SBC, Costa SEVGDA \& KunRath TR (2014) Integrated crop-livestock systems in the Brazilian subtropics. European Journal of Agronomy 57, 4-9.

ERIKSSON M \& AHLGREN S (2013) LCAs for petrol and diesel - a literature review. 36. Swedish University of Agricultural Sciences, Uppsala. 
FERREIRA FDF, NEUMANN PS \& HOFFMANN R (2014) Análise da matriz energética e econômica das culturas de arroz, soja e trigo em sistemas de produção tecnificados no Rio Grande do Sul. Ciencia Rural 44, 380-385.

FERTILIZERS EUROPE (2014) Carbon footprint reference values: energy efficiency and greenhouse gas emissions in european mineral fertilizer production and use. 5. Fertilizers Europe, Brussels.

García R, Pizarro C, Lavín AG \& Bueno JL (2014) Spanish biofuels heating value estimation. Part I: Ultimate analysis data. Fuel 117, Part B, 1130-1138.

GARRITY DP, GINES HC \& No (1990) The development of rice-corn rotations in tropical lowland environments: a systems research approach. In: Extension Bulletin - ASPAC, Food \& Fertilizer Technology Center, Vol. 316, 24p. IRRI, Manila, Philippines.

HAMZEI J \& SEYYEDI M (2016) Energy use and input-output costs for sunflower production in sole and intercropping with soybean under different tillage systems. Soil \& Tillage Research 157, 73-82.

HeICHEL GH (1980) Assessing the fossil energy costs of propagating agricultural crops. In: Handbook of energy utilization in agriculture, Vol. 1. (ed D Pimentel), 27-33. CRC Press, Boca Raton, FL, USA.

IBGE (2016) Banco de Dados Agregados (Aggregated Database). Available at: http://www.sidra.ibge.gov.br/ (accessed 05 Jan 2017).

IPCC (2006) 2006 IPCC Guidelines for National Greenhouse Gas Inventories. Agriculture, Forestry and Other Land Use., (eds. K Paustian, NH Ravindranath \& AV Amstel). Institute for Global Environmental Strategies, Hayama, Japan.

IRGA (2014) Custo de produção de arroz irrigado médio ponderado no Rio Grande do Sul. Sistema de cultivo mínimo (semi direto). Estimativa da safra 2013/14. In: Custo de Produção de Arroz. (ed SDP Setorial), 55. Instituto Rio Grandense do Arroz, Porto Alegre, Brazil.

IRGA (2017) Services and Informations - Cropping Seasons. Available at: http://www.irga.rs.gov.br/conteudo/4215/safras (accessed 05 Jan 2017).

JANSSEN M \& LENNARTZ B (2007) Horizontal and vertical water and solute fluxes in paddy rice fields. Soil and Tillage Research 94, 133-141.

JiA H, WANG W, LUO X, ZHENG J, GUO M \& ZHUANG J (2016) Effects of profiling elastic press roller on seedbed properties and soybean emergence under double row ridge cultivation. Soil and Tillage Research 162, 34-40.

Jiang W, Jiang X, Ye J, Fu Q, Feng Y, Luo J \& Han Z (2011) Rice striped stem borer, Chilo suppressalis (Lepidoptera: Pyralidae), overwintering in super rice and its control using cultivation techniques. Crop Protection 30, 130-133.

KORNECKI TS (2015) Rye termination by different rollers/crimpers developed for No-Till Small-Scale Farms. Applied Engineering in Agriculture 31, 849-856.

Lima ACR, Hoogmoed WB, Pauletto EA \& Pinto LFS (2009) Management systems in irrigated rice affect physical and chemical soil properties. Soil \& Tillage Research 103, 92-97.

MASSONi PFS, MARChESAn E, GROHS M et al. (2013) Influência de manejos pós-colheita do arroz irrigado sobre o banco de sementes de arroz-vermelho. Planta Daninha 31, 89-98. 
MedeIRos LFS (2011) Avaliação da energia contida nos principais sistemas agrícolas e industriais da região médio norte do Estado de Mato Grosso - 2010. Master Thesis, Universidade Federal de Mato Grosso, Cuiabá, MT, Brazil.

PATZEK TW (2004) Thermodynamics of the corn-ethanol biofuel cycle. Critical Reviews in Plant Sciences 23, 519-567.

PIMENTEL D (1992) Energy inputs in production agriculture. In: Energy in farm production, Vol. 6. (ed RC Fluck), 1 edn, 13-29. Elsevier, Amsterdam.

PIMENTEL D (2003) Ethanol fuels: energy balance, economics, and environmental impacts are negative. Natural Resources Research 12, 127-134.

Rocha JM (2011) As Raízes da Crise da Metade Sul. Estudo da formação econômica do Rio Grande do Sul, (ed. Unipampa), 1 edn. Fundação Universidade Federal do Pampa, Jaguarão, RS, Brazil.

SAdeghpour A, Hashemi M, Jahanzad E \& Herbert SJ (2015) Switchgrass stand density and yield as influenced by seedbed preparation methods in a sandy loam soil. Bioenergy Research 8, 1840-1846.

SAS InstituTE (2016) The SAS system for Windows. Version 9.4. Cary, NC.

Saunders C, Barber A \& TAYlor G (2006) Food Miles - Comparative energy/emissions performance of New Zealand's agriculture industry, (ed. AL University). Lincoln University. Agribusiness and Economics Research Unit., Lincoln, New Zealand.

Silva JJC, Theisen G, ANDres A, Silva JLS \& IDEhARA SJ (2012) Avaliação do uso do rolofaca no preparo do solo pós-colheita do arroz irrigado em áreas da planície costeira do RS. In: Documentos, 349, Vol. 1, 28 p. Embrapa Clima Temperado, Pelotas, RS, Brazil.

SINGH TP, SINGH J \& KUMAR R (2006) Study on different tillage treatments for rice - Residue incorporation and its effect on wheat yield in tarai region of Uttaranchal. $A M A$, Agricultural Mechanization in Asia, Africa and Latin America 37, 18-24.

SOSBAI (2014) Arroz irrigado: recomendações técnicas da pesquisa para o sul do Brasil, (ed. Sosbai), 1 edn. Sociedade Sul Brasileira de Arroz Irrigado, Santa Maria, RS, Brazil.

Streck EV, KÄMPf N, DAlmolin RSD et al. (2008) Solos do Rio Grande do Sul. $2 a$ Ed. UFRGS, Departamento de Solos, Faculdade de Agronomia and EMATER/RS, Porto Alegre, RS, Brazil.

Tourino MCC, De Rezende PM \& SALVAdor N (2002) Row spacing, plant density and intrarow plant spacing uniformity effect on soybean yield and agronomic characteristics. Pesquisa Agropecuária Brasileira 37, 1071-1077.

VAlsesia M, Bisaglia C, BOCCHI S \& BordignOn L (2009) Tecniche di coltivazione del riso a basso impatto ambientale: riso secondo natura, (ed. A Editore). Aerre Editore, Gaglianico (Italy).

WOLF D \& LUTH HJ (1979) Tillage equipment for clod-forming soils. Transactions of the Asae 22, 1029-1032.

WuEBKER EF, MULLEN RE \& KOEHLER K (2001) Flooding and temperature effects on soybean germination. Crop Science 41, 1857-1861.

ZHANG X, XIA J, ZHANG J et al. (2016) Working performance experiment of combination blade roller for straw returning in paddy field and dry land. Nongye Gongcheng Xuebao/Transactions of the Chinese Society of Agricultural Engineering 32, 9-15. 



\section{Chapter 5}

\section{Low disturbance and low speed seeding supress weeds in no-tillage soybean}

Article published in Weed Research, Volume 55, Issue 6, December 2015, pp.598-608. doi: 10.1111/wre. 12176

Giovani Theisen *†; Lammert Bastiaans $\dagger$

* Embrapa Temperate Climate, BR 392, km 78, 96010-970, Pelotas, RS, Brazil,

$\dagger$ Centre for Crop System Analysis, Wageningen University, Wageningen, Netherlands 


\title{
Low disturbance and low speed seeding suppress weeds in no-tillage soybean
}

\author{
Giovani Theisen *†; Lammert Bastiaans $\uparrow$ \\ * Embrapa Temperate Climate, BR 392, km 78, 96010-970, Pelotas, RS, Brazil, \\ $\uparrow$ Centre for Crop System Analysis, Wageningen University, Wageningen, Netherlands
}

\begin{abstract}
Germination is a key process in the dynamics of weed populations. In no-tillage systems, crop seeding is often found to induce seed germination in the seeding strip, particularly at higher planting speeds. In this research, experiments were conducted in no till soybean fields in Tres Passos and Cruz Alta, south Brazil. A first experiment revealed that a lower planting speed was effective in reducing the emergence of important weed species. Further experiments were set up to evaluate the ability of a modified seeder to contribute to a further reduction in weed emergence and to study its interaction with planting speed. Coulter disks on the seeder were equipped with lateral blades, to diminish soil disturbance and to properly cut the mulch layer. In a field with a high level of residues, the modified seeder, in contrast to the standard seeder, prevented soil exposure to increase when planting at high speed. Averaged over all seeding rates, the new equipment led to a $56 \%$ reduction in in-row weed density. An increase in overall weed density with planting speed was consistently observed, but with the modified seeder this increase was only half of that with the standard seeder. On average, the modified seeder reduced weed biomass with $33 \%$ and increased soybean grain yield with $42 \%$. The research demonstrated that elements of an integrated weed management strategy, that are increasingly needed to make weed management more sustainable, can be found in relatively simple changes, like a minor modification to a seeder and a lowered planting speed.
\end{abstract}

Keywords: germination, no-tillage, planter, seed dormancy, seeder, soil disturbance, straw. 


\subsection{Introduction}

Conservation agriculture has been one of the pillars of grain production in tropical and subtropical areas of South America. This system is based on three main principles: permanent maintenance of crop residues on the soil surface, crop rotation and absence of soil-disturbing operations like ploughing and harrowing (Machado, 2001). The practice, often simply referred to as no-tillage (NT), has presented advantages over plough-based conventional tillage in terms of ecosystem services (Schipanski et al., 2014), soil resilience (Moraes Sá et al., 2014), soil carbon budget (Liu et al., 2014) and cost effectiveness (Karlen et al., 2013). NT may also contribute to weed suppression as it entails leaving a layer of residues on the soil surface, which diminishes weed seed germination (Bernstein et al., 2014), acts as a physical barrier to weed seedling establishment (Teasdale \& Mohler, 2000) and provides shelter to seed and seedling predators (VanBeek et al., 2014).

Despite the positive attributes, weeds continue to be an important problem in most NT systems, as not all weed species are sufficiently suppressed by the layer of crop residues. In countries such as Argentina, Brazil and USA, a large fraction of the arable land under NT and chemical control is the most utilized method for controlling weeds (Reenberg \& Fenger, 2011). The strong reliance on herbicides is risky and not sustainable, due to increases in herbicide resistance and the environmental impact of chemical control (Bastiaans et al., 2008). Alleviating the dependence on chemical control can be attained by using a more integrated weed management (IWM) strategy (Norsworthy et al., 2012).

In this context, it is noteworthy that in NT systems, crop seeding triggers weed seed germination and creates favourable conditions for weed seedling establishment. The seeding machines create soil disturbance, and this promotes weed seedling recruitment by exposing seeds to light and by changing the micro-environment surrounding the seeds. Soil mobilization is reduced if seeding is conducted at low speed (Modolo et al., 2012), but most farmers cannot always afford to sow slowly, as they need to sow large areas in a short period of time. In addition, seeders sometimes fail to cut the straw layer, particularly if large amounts of residues are present (Seidi et al., 2010). In this case, the seeder pushes the straw inside the furrows, resulting in a less uniform crop establishment, or it drags the mulch over the soil surface, thereby creating a band of uncovered soil, favourable for weed seed establishment.

Weeds that grow in the crop rows rather than between them probably have the largest detrimental effect on grain yield, as they grow closest to the crop plants (Radosevich et al., 
2007). Therefore, preventing seed germination in crop rows should targeted. Seeders have sometimes been modified to minimize soil disturbance (Brandelero et al., 2014) and different models for seeders promoting minimal soil disturbance, like the punch planting system, have been evaluated (Frabetti et al., 2011; Rasmussen et al., 2011). In the current research, a standard no-tillage seeder was adjusted such that soil disturbance in the rows was reduced and large amounts of straw on the soil surface could be successfully handled. To attain this, the coulter disks of the seeder were equipped with sidebars that pressed the straw against the soil when seeding and cleaned the disks of the adhered soil. Preliminary testing showed that the modified seeder adequately cut the cover residues and diminished the soil exposure in crop rows (Theisen $\&$ Bianchi, 2010). The objectives of the current research were to evaluate whether seeding speed and the use of a modified seeder were able to reduce the establishment of weed seedlings in a NT soybean system.

\subsection{Materials and Methods}

\section{Description of experimental fields}

From 2002 to 2004, three field experiments were set up in Cruz Alta (CA, at 28 36.21S; $53^{\circ} 40.5 \mathrm{~W}$ ), Brazil, while in 2003 and 2004 similar experiments were installed in Tres Passos (TP, at $\left.27^{\circ} 60.68 \mathrm{~S} ; 53^{\circ} 53.1 \mathrm{~W}\right)$. In both areas, a no-tillage system (NT) with crop rotation was maintained. The soils in both locations are categorized as dusky-red latosol (Oxisol), with 43\% clay and $4.3 \%$ organic matter in CA and $48 \%$ clay and $3.5 \%$ of organic matter in TP. For both sites, the long-term average annual rainfall is around $1800 \mathrm{~mm}$. Both locations are categorized under the Cfa-2a climate, according to the Köppen's classification (Alvares et al., 2013).

In $\mathrm{CA}$, the crop residues on the soil surface remained from residual mulching of black oat (Avena strigosa Schreb.) cultivated in the previous winter, with 3.2, 2.9 and $4.5 \mathrm{Mg} \mathrm{ha}^{-1}$ dry mass (DM) in 2002, 2003 and 2004, respectively. At TP, the soil in both years was covered by 1.1 $\mathrm{Mg} \mathrm{ha}^{-1} \mathrm{DM}$ of residues of harvested wheat (Triticum aestivum L.). In CA, the cover crop was desiccated with glyphosate at $1.4 \mathrm{~kg}$ a.e. $\mathrm{ha}^{-1} 8$ days before crop seeding, whereas in TP chemical desiccation was not needed.

In all experiments, a non-GMO, medium-cycle soybean (Glycine max (L.) Merrill) was used. The crop was seeded in the first week of November, at 36 seeds $\mathrm{m}^{-2}$, in rows spaced 45 cm apart. All cultural practices, except for weed control, followed official recommendations for soybean in south Brazil (Embrapa, 2012). 


\section{Experiments conducted}

In 2002, a first study with a standard no-tillage seeder was conducted in CA. In this study, the effect of seeder speed (1.7, 5.8 and $9.1 \mathrm{~km} \mathrm{~h}^{-1}$ referred to as low, medium and high, respectively) on weed density in and between crop rows was investigated. One of the purposes of this work was to establish whether differences between weed species occurred in their sensitivity to soil disturbance. In 2003 and 2004, experiments were conducted in CA and TP to evaluate the effects of seeder system (standard and modified) and interaction with seeder speed (low, medium and high) on soil exposure, weed density in and between the crop rows, above-ground weed biomass and soybean yield. Due to characteristics of the tractors used, the velocities in the TP field were slightly lower than in CA $\left(0.9,3.6\right.$ and $7.5 \mathrm{~km} \mathrm{~h}^{-1}$, for low, medium and high, respectively). In 2004, a severe drought in south Brazil stopped all TP experiments shortly after seeding, whereas in CA the experiment was terminated before crop ripening and only data on soil exposure, weed density and weed biomass were collected.

\section{The seeder systems}

The no-tillage seeder contained seven seeding lines $45 \mathrm{~cm}$ apart, each one composed of a frontal 17" sharp flat disk (diameter $43.2 \mathrm{~cm}$ ) to cut the straw, and a staggered, double-disk system (14" and 15"; diameter 35.6 and $38.1 \mathrm{~cm}$ respectively) with rear rubber rollers, to open and close the furrows to seed and fertilizer placement. This seeder was used in its standard configuration, but also in a modified version on which each coulter disk was equipped with metallic blades ( $80 \mathrm{~cm}$ length $\times 8 \mathrm{~cm}$ width) bolted in the disk frame, positioned at $10 \mathrm{~cm}$ above the disk bottom and located on both sides, $1.5 \mathrm{~cm}$ near the disk (Figure 1). The main functions of this tool, named by the field team as the 'ski', were to help the disks cut the straw adequately, to reduce the formation of soil clods, to decrease soil disturbance and to remove the adhered soil on the disks.

\section{Parameters evaluated}

For weed density (WD) plots were subdivided into equally sized strips representing the in-row area $(22.5 \mathrm{~cm}$ wide, centered around the crop row $)$ and the between-row area $(22.5 \mathrm{~cm}$ wide, exactly in between two crop rows). Counts were made in strips with a length of $50 \mathrm{~cm}$ in the three central rows and in the two respective between rows of each plot. Weed seedlings were counted and identified at the species level at the V3-V4 soybean stage (Fehr et al., 1971). 

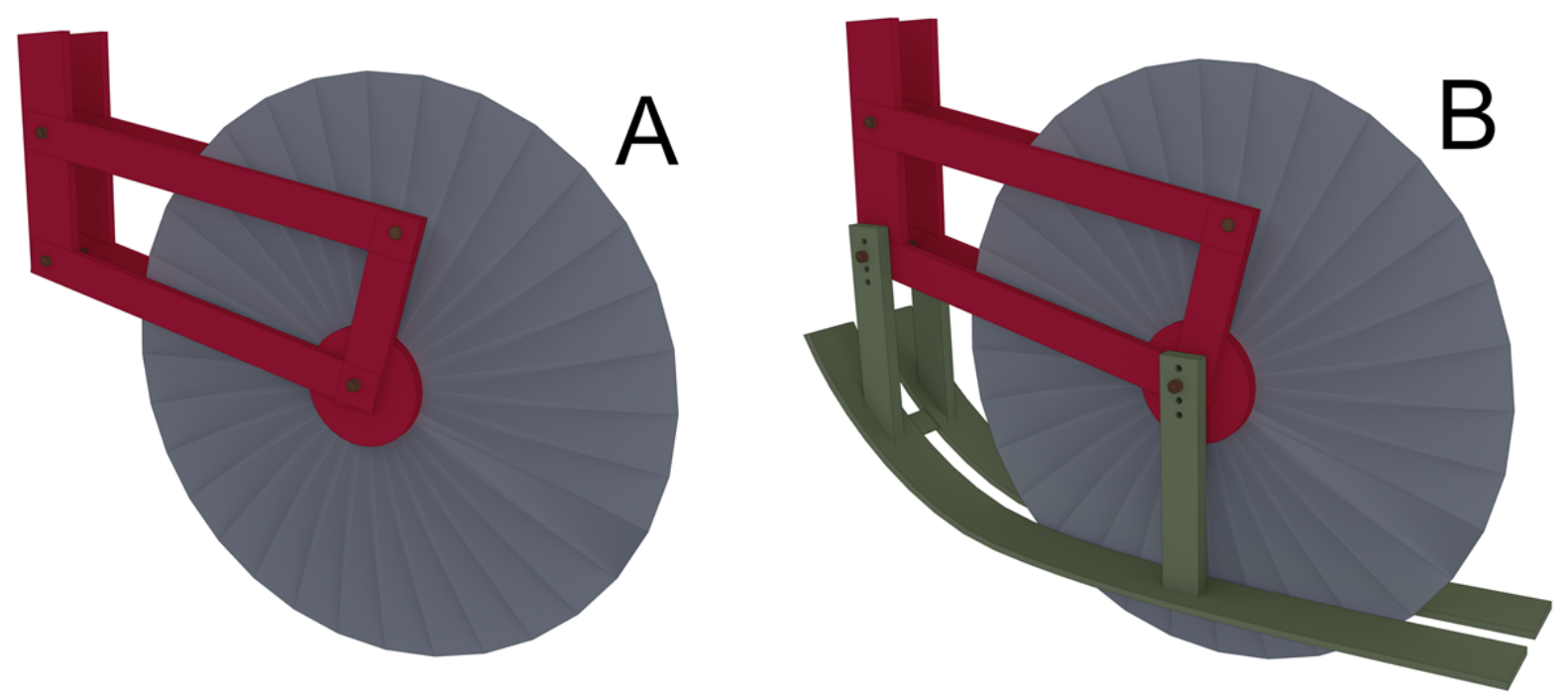

Figure 1. Schematic drawings of a standard (A) and a modified (B) coulter disk of the no-tillage seeder used in the experiments.

Soil exposure was evaluated by means of digital image analysis. Pictures were taken in the middle points of each plot when the crop was between V3 to V5 development stage, with a digital camera fixed at $1.85 \mathrm{~m}$ height. The original images had a resolution of $1600 \mathrm{x} 1200$ dots per inch (dpi) at TP and CA in 2003, and 1280 x 980 dpi at CA in 2004. Each picture covered an area of $1.86 \mathrm{~m} \mathrm{x} 1.40 \mathrm{~m}$. The software ImageJ version 1.48 (Schneider et al., 2012) was used to identify three classes of pixels in the pictures: greenish (soybean and weeds), yellow to greyed (straw) and reddish (soil), using colour separation from the Wu-Quant algorithm, in Color Inspector 3D v2.3, a plugin of ImageJ (Barthel, 2004). To calculate soil exposure, the pixels with reddish colour were expressed as percentage of the total area of each picture.

Above-ground weed biomass was collected in two samples of $1 \mathrm{~m}^{2}$ in each plot, at R4 soybean stage. The material was dried at $60^{\circ} \mathrm{C}$ for 2 days before weighing. Soybean yield was evaluated by hand-harvesting the three central rows of each plot at $\mathrm{R} 8$ stage, in lines $5.0 \mathrm{~m}$ long. Grain yield was adjusted to $13 \%$ moisture.

\section{Statistical analysis}

In the first study, the experimental scheme was a single-factor, one-way design. ANOVA was used to test the effect of seeder speed on the density of the four most abundant weed species in rows, in between rows and $\sum$ (rows + between rows) of soybean. Additionally, a set of t-tests were performed to compare weed density in crop rows and between rows for each species and seeder speed. In all other experiments, the experimental scheme was a split-plot design, with seeder system as main plot and seeder speed as subplot. In these experiments, all weed data 
were pooled. The experimental plots were $7.0 \mathrm{~m}$ long by $3.6 \mathrm{~m}$ wide, and each treatment was replicated either four times (2002 and 2003) or three times (2004). Data were subjected to normality tests, and soil exposure and weed density data were square root transformed before ANOVA. Linear equations for weed density and above-ground weed biomass against seeder speed were derived in SAS Software version 9.3 (SAS Institute, 2016). The equations were considered valid if the slope was different from zero, at level of $p \leq 0.05$.

ANOVA was performed using mixed models in the bi-factorial, split-plot experiments, using the Mixed procedure in SAS Software. Seeder type and seeder speed were assigned as fixed factors, and blocks were assigned as a random factor. The means of treatments were compared using Tukey-Kramer adjusted LSD, with a pre-determined level of significance for differences defined up to $p \leq 0.1$ as cut-off. All data are presented in original scales with respective standard errors (SE). Means and SE of weed density and soil exposure were backtransformed from square root, using Delta method for SE (Onofri et al., 2010).

\subsection{Results}

\section{Effect of speed of a standard seeder on species-specific weed density}

In this first experiment, conducted in Cruz Alta (CA), the average weed density in the soybean rows was $38 \pm 4.9$ plants $\mathrm{m}^{-2}$, contrasting with $12 \pm 2.3$ plants $\mathrm{m}^{-2}$ in between crop rows. The number of weeds in the crop rows was affected $(p \leq 0.002)$ by seeder speed, with $26 \pm 4.2,29$ \pm 7.4 and $65 \pm 12.3$ plants $\mathrm{m}^{-2}$, for low, medium and high speed, respectively. Weed density in between crop rows was not affected $(p=0.56)$ by seeder speed. The most abundant weed species presented species-specific responses to seeder speed (Figure 2). The overall density of Brachiaria plantaginea (Link) Hitchc. (synonym: Urochloa plantaginea (Link) R.D. Webster) (alexandergrass) and Bidens pilosa L. (hairy beggar-ticks) was increased when soybean was seeded at high speed. Clearly, these species were sensitive to the effects of highest seeder velocity. In contrast, the overall density of Ipomoea grandifolia (Dammer) O'Donnel (morning glories) and Euphorbia heterophylla L. (milkweed) was not affected by seeder speed (Figure 2). Seeding soybean at highest speed resulted in a strong difference in weed density in the rows, compared with between rows, especially for B. plantaginea, B. pilosa and I. grandifolia. This preliminary study indicated the existence of the potential to reduce the density of some of the most common weed species in no-tillage soybean fields, by simply reducing the speed of operation of seeders. 
Results obtained with both seeders, operated at three seeding speeds

Soil exposure. In the TP field, the small amount of residues on the soil surface resulted in a high level of soil exposure (around 45\%). Soil exposure was neither affected by seeder system ( $p=$ 0.95 ) nor by seeder speed ( $p=0.82$ ) (Figures 3 and 4). In CA, soil exposure averaged only $9 \pm$ $0.5 \%$ and $3 \pm 0.4 \%$ for the 2003 and 2004 seasons, respectively. In both experiments conducted in CA, there was an interactive effect between seeder system and seeder speed ( $p \leq 0.09$ (in 2003 ) and $p \leq 0.05$ (in 2004)). In both seasons, the modified seeder, regardless of seeding speed, resulted in lower levels of soil exposure if compared to the standard seeder seeding at medium or high speed (Figure 3). For the standard seeder, seeding at the lowest speed resulted in smaller soil exposure than seeding at high speed. With the modified seeder, no significant differences in soil exposure between driving speeds were observed.

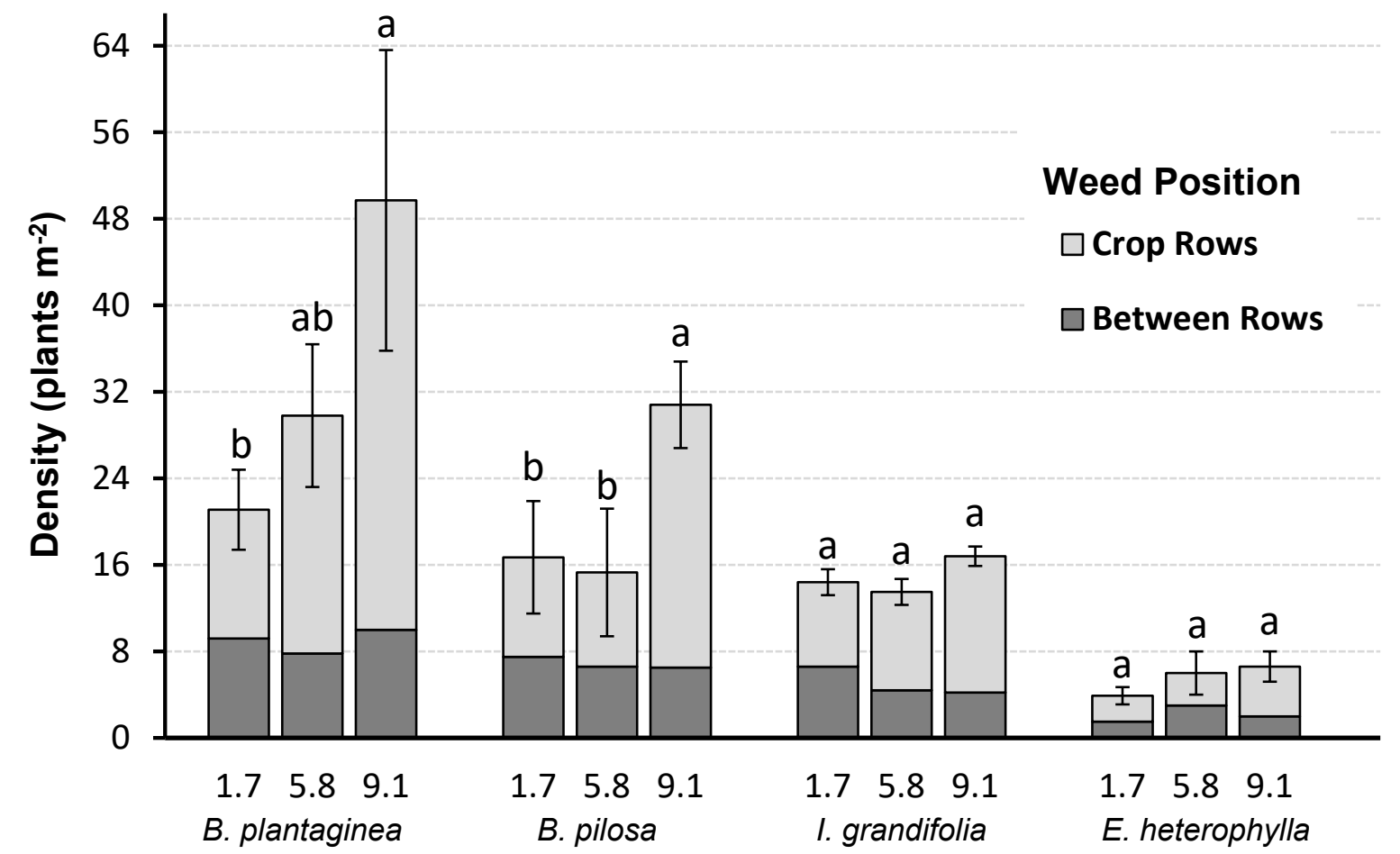

Seeder speed $\left(\mathrm{km} \mathrm{h}^{-1}\right)$ and Weed Species

Figure 2. Density of weeds at V4-stage of soybean seeded at three speeds with a standard seeder in no-tillage system. Vertical bars indicate SE of pooled (rows + between rows) weed density. Within the same species, means of columns with same letter are not significantly different, according to Tukey-Kramer test $(p \leq 0.05)$. 

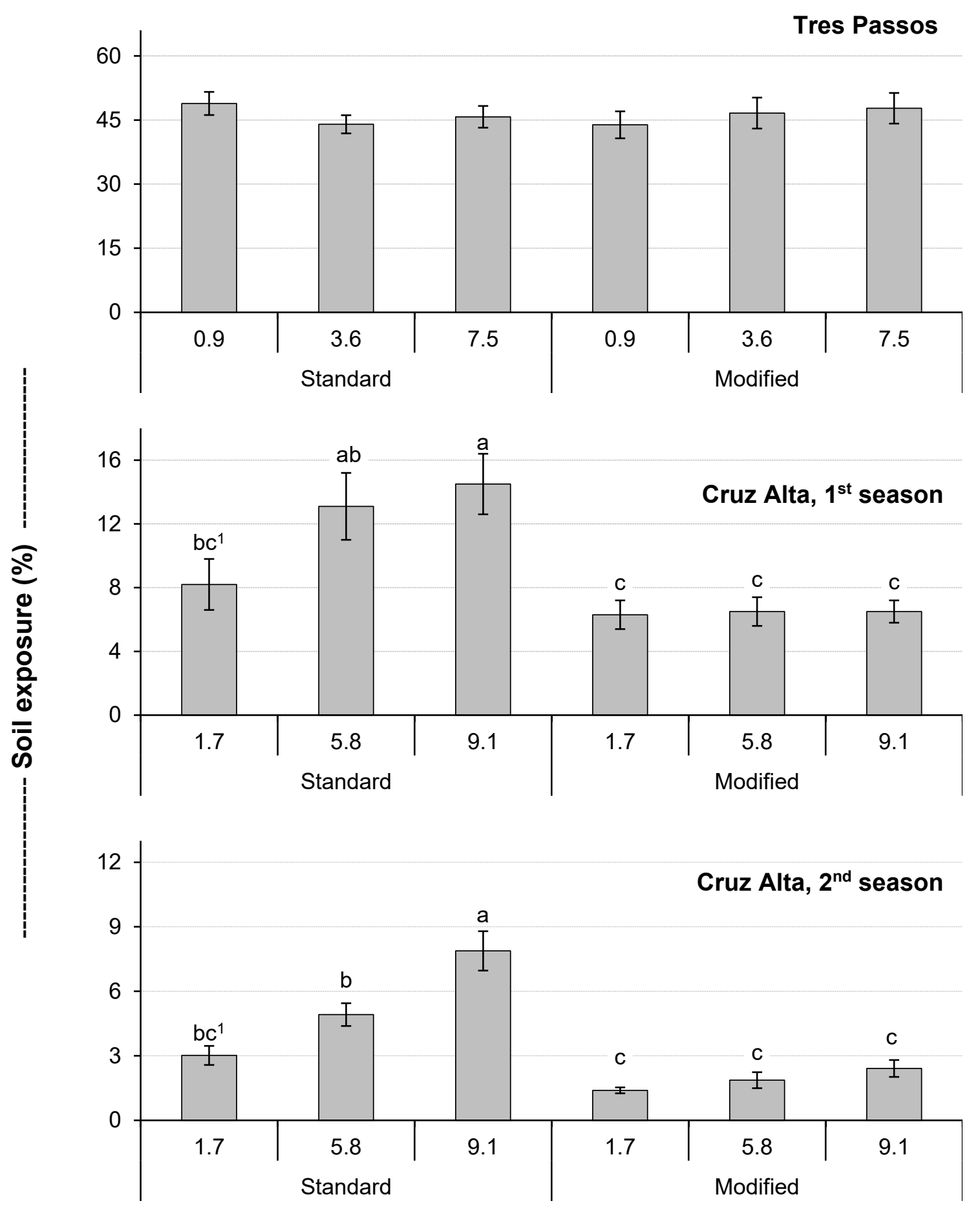

Seeder speed $\left(\mathrm{km} \mathrm{h}^{-1}\right)$ and Seeder system

Figure 3. Soil exposure in soybean fields as affected by seeder speed and seeder system. Vertical bars indicate SE. ${ }^{1}$. Within same location and season, means of columns with distinct letters are significantly different, according to Tukey-Kramer test $(p \leq 0.1)$. No significant differences were found in Tres Passos. 


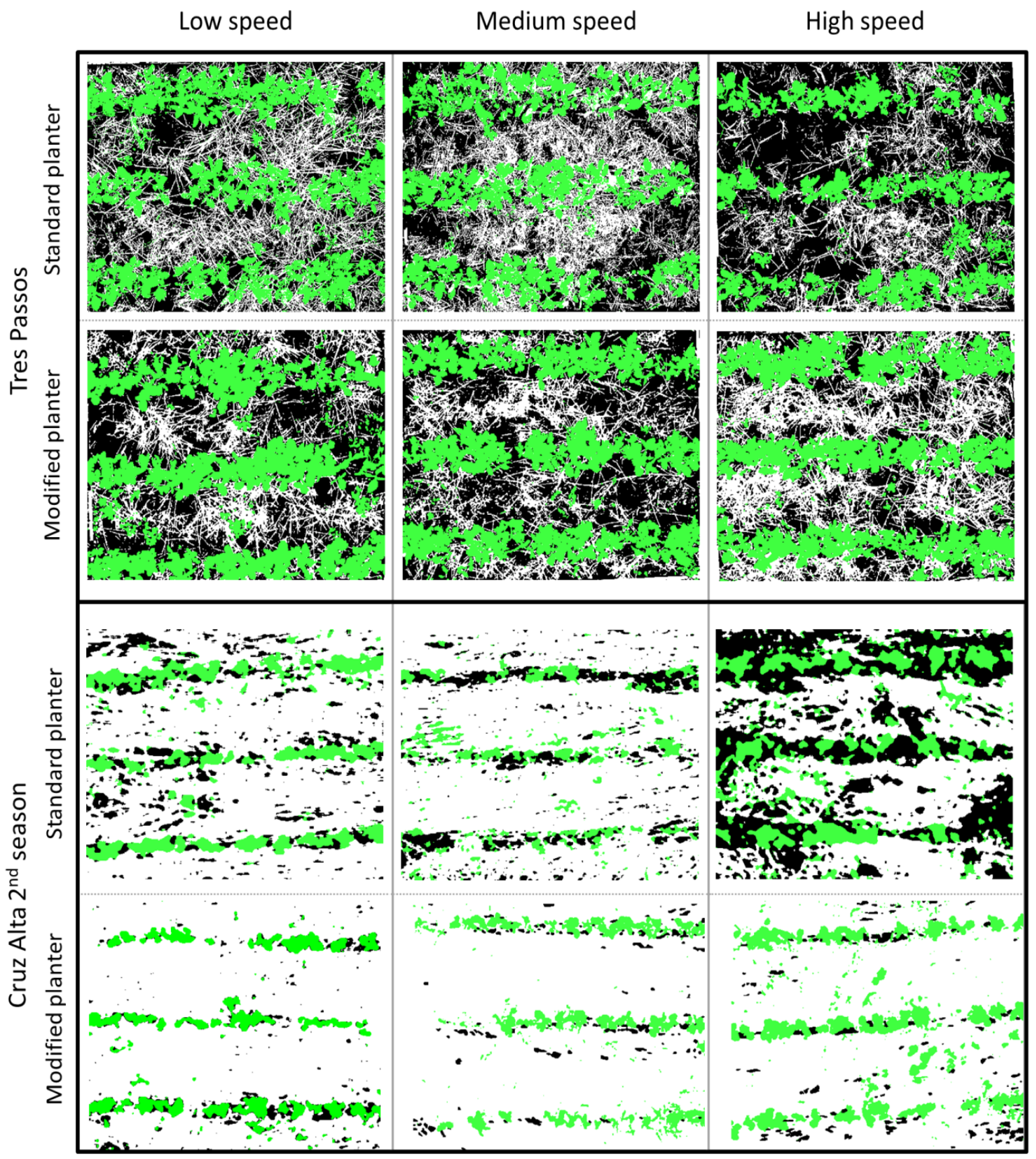

Figure 4. Post-processed pictures from plots with soybean seeded at three speeds using two distinct seeder systems. Black, white and green represent exposed soil, mulching layer and green plants (soybean+weeds), respectively.

Weed density. Despite a smaller amount of residues on the soil, the field at the TP site showed a lower weed infestation than at the CA site. The averaged pooled weed density in TP was 20 \pm 1.8 plants $\mathrm{m}^{-2}$, contrasting with $127 \pm 11.3$ and $101 \pm 11.8$ plants $\mathrm{m}^{-2}$ in CA for the 2003 and 2004 seasons respectively (Figure 5). In Tres Passos, the weed community consisted of E. 
heterophylla (37\%), Digitaria ciliaris (Retz.) Koeler (21\%), Sonchrus oleraceus L. (17\%), Richardia brasiliensis Gomes (15\%), and Soliva pterosperma (Juss.) Less. (10\%). There was an interactive effect between seeder system and seeder speed on weed density in the crop rows $(p \leq 0.09)$. Weed density within crop rows was greater for the standard seeder operating at high speed compared with low speed. For the modified seeder, no increase in weed density with seeding speed was observed (Figure 5-A). At this location, weed densities in between crop rows were neither significantly affected by seeder speed $(p=0.97)$, nor by seeder system $(p=0.12)$ (Figure 5-B).

In CA, the weed community in 2003 was mainly composed of B. plantaginea (62\%), E. heterophylla (11\%), B. pilosa (8\%), Amaranthus viridis (6\%), Sida rhombifolia L. (6\%) and Ipomoea spp. (5\%). In 2004, the community was dominated by B. plantaginea (52\%) and Ipomoea spp. (41\%). Unlike in TP, there was no interaction between seeder speed and seeder system for weed density in the crop rows. In both years, a significant effect of seeder speed ( $p$ $\leq 0.001$ ) was found and a higher weed density in the rows was obtained at the highest seeding speed. The modified seeder resulted in a lower weed density ( $p \leq 0.001$ in both seasons) than the standard seeder (Figure 5C and E). For weeds in between rows, a significant effect of seeder speed ( $p \leq 0.03$ and $p \leq 0.05$ in 2003 and 2004 respectively) was observed (Figure 5D and F). Higher weed numbers were obtained at the highest seeding speed, compared with seeding at the lowest speed. Differences between low and medium speed were not significant, and only in the second season, a significant difference between medium and high speed was observed. In 2003, weed density in between the crop rows was significantly affected $(p \leq 0.001)$ by seeder system, with reduced weed numbers for the modified system (Figure 5D). In 2004, such a difference was not observed ( $p=0.16$; Figure 5F).

The two seeders presented distinct outcomes in relation to how an increased seeding speed affected the weed density averaged over in-row and between-row data (referred to as overall weed density; Figure 6A, C and E). 

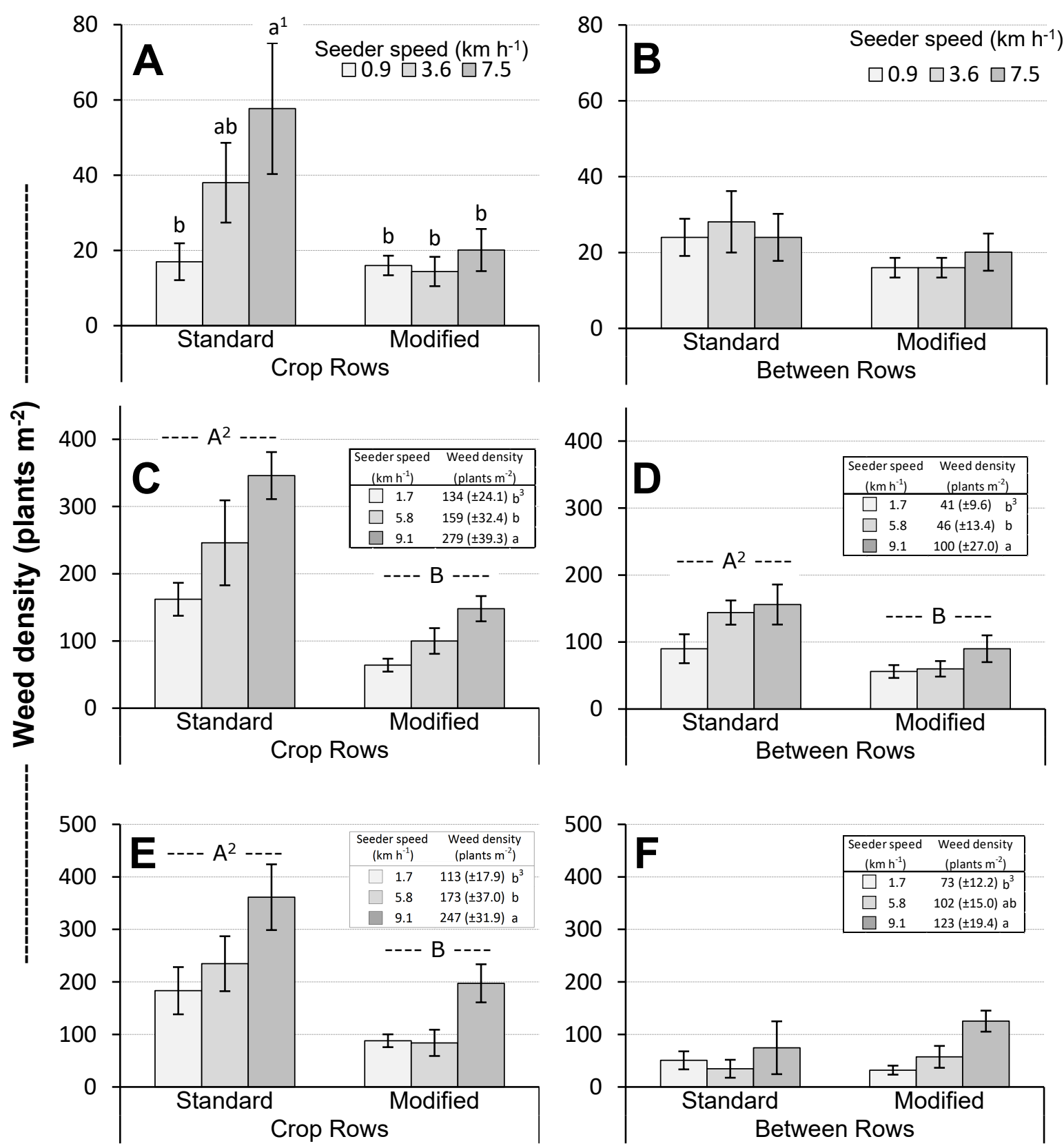

Seeder System and Weed position

Figure 5. Weed density in rows and between rows of soybean as affected by seeder system and seeder speed. Vertical bars indicate SE. ${ }^{1 \cdot}$ Means of columns with same lowercase letters are not significantly different $(p \leq 0.1) .{ }^{2}$ Capital letters compare speed-averaged seeder systems within each weed position $(p \leq 0.1) .{ }^{3}$. Within each weed position, seeder speed followed by same letter are no significantly different $(p \leq 0.05)$. All comparisons were performed with Tukey-Kramer test. $\mathrm{A}$ and $\mathrm{B}=$ Tres Passos, 2003; C and D = Cruz Alta, 2003; E and F = Cruz Alta, 2004. 
When using the standard equipment, the increase in velocity was accompanied by a linear increase in weed density, in both TP and CA. In TP, the increase in weed plant density was just above 3 plants $\mathrm{m}^{-2}$ for each $\mathrm{km} \mathrm{h}^{-1}$. In the highly weed-infested CA field, each $\mathrm{km} \mathrm{h}^{-1}$ increase in seeding speed increased weed density with around 17 plants $\mathrm{m}^{-2}$, for both seasons. When seeding with the modified seeder, a significant linear trend occurred only in CA, and the modified seeder presented smaller slopes than for the standard seeder (around 8 and 10 plants $\mathrm{m}^{-2} / \mathrm{km} \mathrm{h}^{-1}$ for the $1^{\text {st }}$ and $2^{\text {nd }}$ season respectively). This indicates that even minor changes in the speed of a standard seeder can result in a large impact on weed density, especially in soils with a large weed seedbank. The use of the modified seeder permitted to sow at a higher velocity, while keeping the weed density at a level comparable with that of a standard seeder operating at low speed.

Above-ground weed biomass. The averaged biomass of adult weeds was $81 \pm 10.8,84 \pm 6.7$ and $32 \pm 2.5 \mathrm{~g} \mathrm{~m}^{-2}$ for TP, CA (2003) and CA (2004) respectively. The smaller amount of weed biomass in CA (2004), resulted from the severe drought affecting the experiments. In TP, the effects of seeder speed on above-ground weed biomass were similar for both seeders. In this site, weed biomass increased with $6.5 \mathrm{~g} \mathrm{~m}^{-2}$ per unit increase in seeding speed $\left(\mathrm{km} \mathrm{h}^{-1}\right.$; Figure 6B). In the more weed-populated CA site, the modified seeder limited the impact of seeding speed on weed biomass. In the first season, the increase in weed biomass for each $\mathrm{km} \mathrm{h}^{-1}$ increase in seeding rate lowered from $7.47 \mathrm{~g} \mathrm{~m}^{-2}$ for the standard seeder to $3.94 \mathrm{~g} \mathrm{~m}^{-2}$ for the modified seeder (Figure 6D), whereas in the second season a reduction from $2.35 \mathrm{~g} \mathrm{~m}^{-2}$ to 1.58 $\mathrm{g} \mathrm{m}^{-2}$ was observed (Figure $6 \mathrm{~F}$ ).

Soybean yield. In TP, no significant effect of seeder speed $(p=0.35)$ on soybean grain yield was observed (Table 1). However, in the highly weed-infested CA field, seeding soybean at low speed resulted in a higher grain yield than seeding at high speed $(p \leq 0.003)$. A similar result was observed in the preliminary experiment conducted in CA (data not shown). In both sites, the modified seeder promoted larger grain yield than the standard seeder $(p \leq 0.001$ and $p \leq 0.006$ for TP and CA respectively). The extra yield obtained using the modified seeder varied from $29 \%$ in TP to $55 \%$ in CA. In both sites, no interaction between seeder speed and seeder system was observed. Due to the occurrence of a severe drought, the experiment in CA in 2004 was terminated before crop maturity. 

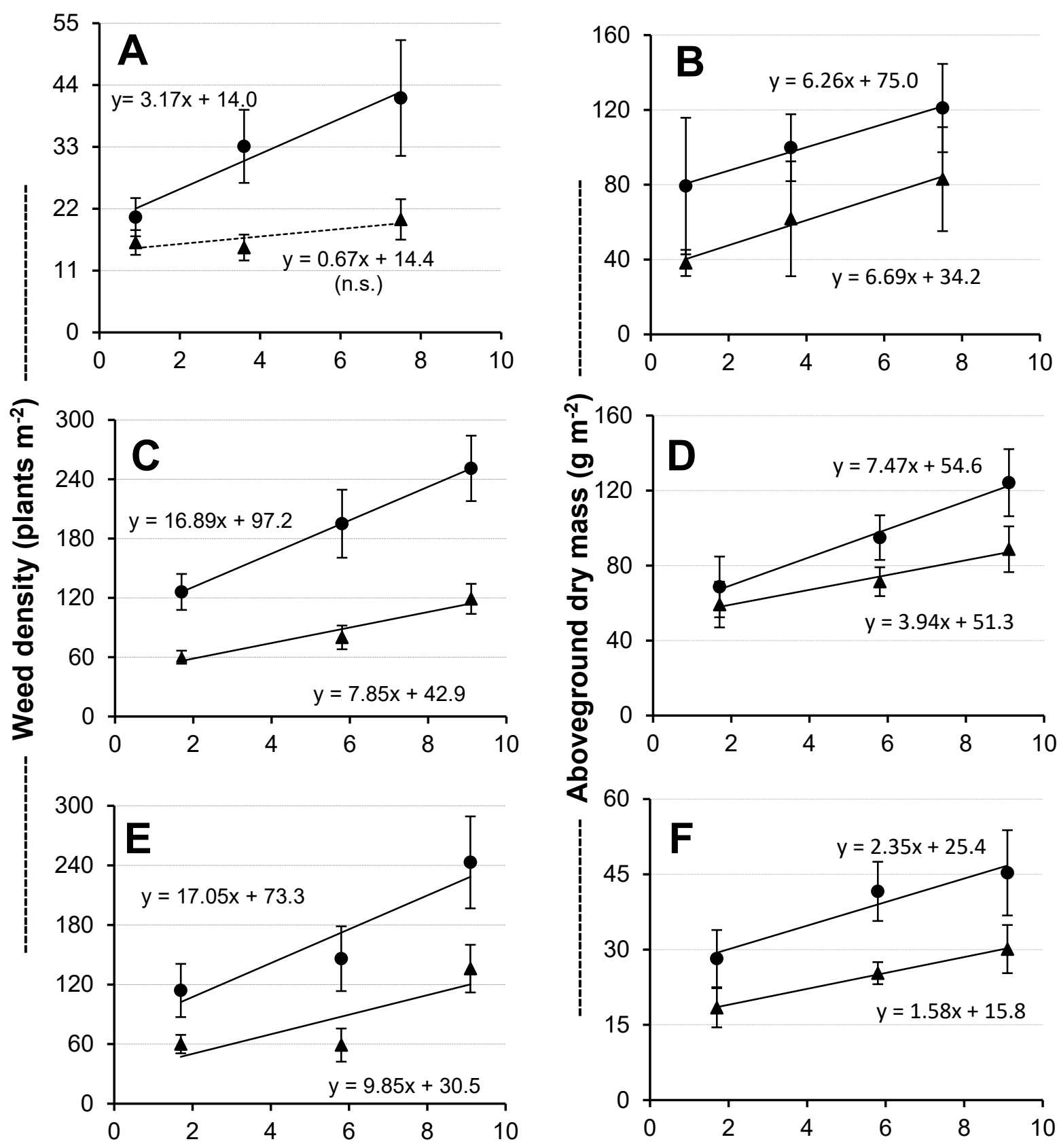

Seeder Speed $\left(\mathrm{km} \mathrm{h}^{-1}\right)$

Figure 6. Weed density (averaged over in-row and between-row of soybean) and weed aboveground biomass as affected by seeder system and seeder speed. Vertical bars indicate SE. Except for equation followed by "n.s.", all slopes in equations are significantly different from zero at 0.05 level. $\bullet=$ Standard Seeder; $\boldsymbol{\Delta}=$ Modified Seeder. A and B = Tres Passos, 2003; $\mathrm{C}$ and $\mathrm{D}=$ Cruz Alta, 2003; E and F = Cruz Alta, 2004. 
Table 1 . Soybean grain yield $\left(\mathrm{kg} \mathrm{ha}^{-1}\right)$ as affected by seeder system and seeder speed in Tres Passos and Cruz Alta ( $1^{\text {st }}$ season).

\begin{tabular}{ccccc}
\hline & \multicolumn{3}{c}{ Seeder Speed $^{1}$} \\
Seeder \\
\cline { 2 - 4 } System & Low & Medium & \multirow{2}{*}{ High } \\
\cline { 2 - 4 } & \multicolumn{3}{c}{ Tres Passos } \\
\hline Standard & $1642(148.3)$ & $1454(144.2)$ & $1567(86.0)$ & $1554(71.4) \mathrm{A}^{2}$ \\
Modified & $2068(217.0)$ & $2074(138.6)$ & $1851(52.7)$ & \multirow{2}{*}{$1998(85.2) \mathrm{B}$} \\
\cline { 2 - 4 } $\bar{x}$ & $1855(145.9)$ & $1764(149.3)$ & $1709(71.1)$ & \\
\hline & & Cruz Alta & $577(74.6) \mathrm{A}$ \\
Standard & $799(157.4)$ & $540(85.3)$ & $393(31.3)$ & \\
Modified & $1236(156.3)$ & $857(142.0)$ & $584(116.9)$ & \\
\cline { 2 - 4 } & $1017(131.8) \mathrm{a}^{3}$ & $698(97.3) \mathrm{b}$ & $489(66.7) \mathrm{b}$ & \\
\hline
\end{tabular}

Values between parentheses indicate SE. ${ }^{1}$ Low $=0.9$ to $1.7 \mathrm{~km} \mathrm{~h}^{-1} ;$ Medium $=3.6$ to $5.8 \mathrm{~km} \mathrm{~h}^{-1}$; High $=7.5$ to $9.1 \mathrm{~km} \mathrm{~h}^{-1}$, with smaller velocities used at Tres Passos field. ${ }^{2}$ Within each site, the means of seeder system following distinct letters are significantly different, according to Tukey-Kramer test $(p \leq$ $0.05) .{ }^{3 .}$ Means of seeder speed followed by distinct letters are significantly different, according to Tukey-Kramer test $(p \leq 0.05)$.

\subsection{Discussion}

The maintenance of weed seeds near to the soil surface in no-tillage systems implies that the seedbank is frequently subjected to severe environmental and agronomic interferences. While this can account for a faster depletion in seed viability, it also easily results in high weed densities, evoked by the easy breakage of seed dormancy near the soil surface (Benvenuti et al., 2001). The presence of a large germinable seedbank near the soil surface suggests that even a shallow stimulus by seeders represents a significant influence on the weed infestation level in no-tillage areas. The current research confirmed this point, as the weed density within the soybean rows was greater than the density observed between the rows, resulting from the localized effect of the seeder. This result differs from studies conducted in conventional fields, where seedbed preparation creates a uniformly applied soil disturbance over the entire field and weed infestation level in and between rows is quite similar (e.g. Longchamps et al., 2012).

Weeds remain a problem in conservation agriculture and to make their management less reliant on herbicides, new strategies that contribute to a more integrated weed management approach are welcomed. In the present work, we found that a reduction in seeder speed and a relatively simple adaptation in the coulter disks system of a no-tillage seeder were both able to 
reduce soil exposure and the accompanying weed infestation levels in NT fields. With the modified device, soil exposure became independent of seeder speed. Due to the structural conformation of the blades alongside the coulter disks, the improved seeder left the straw mostly undisturbed while the seeder performed its action in the field and avoided soil clods to be thrown to inter-row space. Its application resulted in relatively low levels of soil exposure even at high seeding speeds. This, the environmental factors affecting weed seed dormancy and germination in soil were probably barely affected. The reduced weed infestation was an important consequence resulting from the use of the modified seeder. In addition, apart from weed suppression, preserving a uniform mulch layer in the NT fields was also reported to provide additional benefits in terms of biodiversity (Sapkota et al., 2012), prevention of erosion (Machado \& Silva, 2001) and reduced water losses from the soil (Palm et al., 2014).

Differences between the germination response of weed species probably originate from interspecific differences in seed dormancy pattern. The dormancy of B. plantaginea seeds is temperature-regulated and thus strongly affected by the crop residue layer on the soil surface and by the seed position in the soil profile (Salvador et al., 2007). Bidens pilosa has heteromorphic seeds, with different responses to light (Amaral-Baroli \& Takaki, 2001). Typically, the density of these two species increased at higher seeder speed. In contrast, germination of E. heterophylla is mostly light-independent (Salvador et al., 2007) and the seeds can germinate even under high levels of residue material on the soil surface (Marques et al., 2012). For I. grandifolia the seed dormancy is attributed to physical sealing of the seed coat (Jayasuriya et al., 2009). The interruption of dormancy is light-independent, and seeds of $I$. grandifolia, like those of E. heterophylla, can germinate deeper in the soil profile (Orzari et al., 2013). It is likely, that the same characteristic also makes the germination of the last two species less sensitive to soil disturbance.

In our experiments, in the field with a dense layer of residues on the ground surface (CA site), the increase in seeder speed increased the fraction of soil exposure substantially. However, this effect was only seen in plots seeded with a standard seeder and not in those seeded with the modified seeder. If the previous crop did not provide adequate soil coverage, like in the TP site where $54 \%$ of the soil was covered, seeder speed and seeder system did not affect soil exposure (Figures 3 and 4). Interestingly, the standard seeder still promoted seed germination at medium and high seeding speed. This finding suggests that apart from its effect on soil exposure in the rows, the standard seeder also affected weed seed germination through its effect on physical soil disturbance. In CA fields, which contained a high amount of crop residues, as well as a 
high weed density, the reduced soil disturbance of the modified seeder was insufficient to fully prevent an effect of seeder speed. In these circumstances, the modified seeder was effective in maintaining low levels of soil exposure even at higher seeding speed (Figures 3 and 4), but the weed density still increased with seeder speed (Figure 5). The modified seeder, however, attenuated the effect of seeding speed on weed density (Figure 6). Using this equipment, the increase in weed density due to speed was always less compared with the increase observed with the standard seeder. The superiority of the modified seeder was also revealed by the reduction in weed biomass (Figure 6) and the increase on grain yield (Table 1), relative to that of the standard seeder.

Farmers normally seed crops at high speed, to cover large areas in a short period of time. Probably due this fact and due the scarcity of tests about the effects of seeders on weeds, reducing the speed of seeders is an approach rarely evoked in Integrated Weed Management tactics. Our results, however, consistently show that this strategy can be useful and feasible, especially on small farms where the time required for seeding the crop does not form a restriction, and to fields where the options for integrated management are limited. Results in the highly weed-infested field in CA confirmed that, regardless of seeder system, the lowest driving speed translated in grain yields that were significantly higher than at higher seeding speeds. The results further demonstrated that the conversion to a modified seeder greatly contributed to better weed management. However, this transformation was not sufficient to completely resolve the weed problem in all situations. If farmers encounter high weed infestation levels and cannot afford to sow at low speed, the use of the modified seeder only presents a partial solution to the weed problem. This is not surprising, as it has been frequently observed that cultural control measures need to be applied in combination to e sufficient5ly powerful for tackling a weed problem. Liebman and Gallandt (1997) referred to this concept as the strategy of the 'many little hammers'.

The need to combine different measures to guarantee adequate weed management efficacy obviously increases the complexity of the system, and this was considered an important barrier for the adoption of ecological weed management systems (Bastiaans et al., 2008). At the same time, such composite strategies are believed to be more sustainable, as resistance to any single component is far less likely to occur. In current times, where weed control frequently relies exclusively on one single herbicidal compound, resistance development is strongly promoted, thereby creating hard-to-control weed problems. The lack of sustainability of this chemically oriented system, also amplified by the environmental problems it creates, is likely 
to stimulate the interest in alternative strategies for weed management. In this point of view, and because the technology of no-tillage seeders for cutting straw on the soil surface is almost unchanged in the last decade, the proposed technology, by simplicity and efficacy, can be considered a valuable option for renovation of the current system.

This work contributes towards a more ecologically based weed management, and can be summarized by the following findings: (i) reducing the speed of a standard seeder reduces weed densities in no-tillage fields; (ii) use of the modified seeder minimises soil exposure and soil disturbance at seeding and makes it possible to seed soybean at high or medium seeding speed, thereby obtaining the same benefits in terms of weed suppression as obtained through the use of a lower speed when seeding the crop with a standard seeder; and (iii) the strongest seeder-related effects occur in the rows of soybean, the position where normally the higher weed densities are observed.

\subsection{Acknowledgements}

The authors wish to thank the teams of CCGL-TEC (Cruz Alta, RS, Brazil) and Unitec (Três de Maio, RS, Brazil) for providing infrastructure and personal assistance in the experiments. The author declares there is no conflict of interest involved in producing this manuscript.

\subsection{References}

Alvares CA, Stape JL, Sentelhas PC, de Moraes Goncalves JL \& Sparovek G (2013) Koppen's climate classification map for Brazil. Meteorologische Zeitschrift 22, 711728.

AMARAL-BAROLI A \& TAKAKI M (2001) Phytochrome controls achene germination in Bidens pilosa L. (Asteraceae) by very low fluence response. Brazilian Archives of Biology and Technology 44, 121-124.

BARTHEL KU (2004) Color Inspector 3D. Available at: http://rsb.info.nih.gov/ij/plugins/colorinspector.html (accessed 02 June 2015).

BASTIAANS L, PAOLINI R \& BAUMANN DT (2008) Focus on ecological weed management: what is hindering adoption? Weed Research 48, 481-491.

BENVENUTI S, MACCHIA M \& MiELE S (2001) Quantitative analysis of emergence of seedlings from buried weed seeds with increasing soil depth. Weed Science 49, 528-535.

Bernstein ER, Stoltenberg DE, Posner JL \& Hedtcke JL (2014) Weed community dynamics and suppression in tilled and no-tillage transitional organic winter ryesoybean systems. Weed Science 62, 125-137.

BRANDELERo EM, DE ARAuJo AG \& RALISCH R (2014) Soil mobilization and seeding depth by no-till seeder mechanisms for residue management. Engenharia Agricola 34, 263-272. 
EMBRAPA (2012) Indicações técnicas para a cultura da soja no Rio Grande do Sul e em Santa Catarina, safras 2012/2013 e 2013/2014. In: XXXIX Reunião de Pesquisa de Soja da Região Sul, Vol. Documentos, 7. (ed Leila Maria Costamilan [Et Al.]), 1 edn, 142. Embrapa Trigo, Passo Fundo.

Fehr WR, Caviness CE, Burmood DT \& Pennington JS (1971) Stage of development descriptions for soybeans, Glycine max (L.) Merrill. Crop Science 11, 929-931.

FrabetTI DR, RESENDE RC, QUEIROZ DM, FERnANDES HC \& Solza CM (2011) Development and evaluation performance of a punch planter for direct sowing of corn. Revista Brasileira de Engenharia Agricola e Ambiental 15, 199-204.

JAYASURIYA KMGG, BASKIN JM, GENEVE RL \& BASKIN CC (2009) Sensitivity cycling and mechanism of physical dormancy break in seeds of Ipomoea hederacea (Convolvulaceae). International Journal of Plant Sciences 170, 429-443.

Karlen DL, Kovar JL, CAMBARdella CA \& COLvin TS (2013) Thirty-year tillage effects on crop yield and soil fertility indicators. Soil and Tillage Research 130, 24-41.

LiEBMAN M \& GALlANDT ER (1997) Many Little Hammers: Ecological Management of CropWeed Interactions. In: Ecology in Agriculture, Vol. 1. (ed LE Jackson), 1st edn, 291343. Academic Press, San Diego, CA.

LIU C, LU M, CUI J, Li B \& FANG C (2014) Effects of straw carbon input on carbon dynamics in agricultural soils: a meta-analysis. Global Change Biology 20, 1366-1381.

LongChamps L, PAnneton B, Simard M-J \& Leroux GD (2012) Could weed sensing in corn interrows result in efficient weed control? Weed Technology 26, 649-656.

MACHADO PLOD \& Silva CA (2001) Soil management under no-tillage systems in the tropics with special reference to Brazil. Nutrient Cycling in Agroecosystems 61, 119-130.

MARQues RP, MARTins D, DE Almeida Costa SI \& Vitorino HdS (2012) Densities straw and luminosity conditions on seed germination on seed germination of Euhphorbia heterophylla. Semina-Ciencias Agrarias 33, 867-872.

Modolo AJ, Trogello E, Pagliosa ES, Dallacort R, Kolling EM \& Sgarbossa M (2012) Seeding quality and soybean yields from using different furrowers and operation speeds. Semina-Ciencias Agrarias 33, 3009-3015.

Moraes Sá JC, Tivet F, Lal R, Briedis C, Hartman DC, dos Santos JZ \& dos Santos JB (2014) Long-term tillage systems impacts on soil $\mathrm{C}$ dynamics, soil resilience and agronomic productivity of a Brazilian Oxisol. Soil and Tillage Research 136, 38-50.

NORSWORTHY JK, WARD SM, SHAW DR et al. (2012) Reducing the risks of herbicide resistance: best management practices and recommendations. Weed Science 60, 31-62.

Onofri A, Carbonell EA, Piepho HP, Mortimer AM \& Cousens RD (2010) Current statistical issues in Weed Research. Weed Research 50, 5-24.

OrZari I, Monquero PA, Reis FC, SABbag RS \& Hirata ACS (2013) Germination of Convolvulaceae family species under different light and temperature conditions and sowing depth. Planta Daninha 31, 53-61.

Palm C, Blanco-Canqui H, DeClerck F, Gatere L \& Grace P (2014) Conservation agriculture and ecosystem services: an overview. Agriculture Ecosystems and Environment 187, 87-105.

RADOSEVICH SR, Holt JS \& GUERSA CM (2007) Ecology of weeds and invasive plants: 
relationship to agriculture and natural resource management, (ed. T Edition). John Wiley \& Sons, INC., Hoboken, New Jersey.

Rasmussen J, Henriksen CB, Griepentrog HW \& Nielsen J (2011) Punch planting, flame weeding and delayed sowing to reduce intra-row weeds in row crops. Weed Research 51, 489-498.

REENBERG A \& FENGER NA (2011) Globalizing land use transitions: the soybean acceleration. Geografisk Tidsskrift-Danish Journal of Geography 111, 85-92.

Salvador FL, Victoria Filho R, Alves ASR, Simoni F \& SAn Martin HAM (2007) Effect of light and dormancy break on weed species seed germination. Planta Daninha 25, 303-308.

SAPKota TB, MAZzoncini M, BARberi P, ANTICHI D \& Silvestri N (2012) Fifteen years of no till increase soil organic matter, microbial biomass and arthropod diversity in cover crop-based arable cropping systems. Agronomy for Sustainable Development 32, 853863.

SAS InstitUTE (2016) The SAS system for Windows. Version 9.4. Cary, NC.

SCHIPANSKi ME, BARBERCHECK M, Douglas MR et al. (2014) A framework for evaluating ecosystem services provided by cover crops in agroecosystems. Agricultural Systems $125,12-22$.

SCHNEIDER CA, RASBAND WS \& ELICEIRI KW (2012) NIH Image to ImageJ: 25 years of image analysis. Nature Methods 9, 671-675.

Seidi E, Abdollahpour S, Javadi A \& Moghaddam M (2010) Effects of novel disk-type furrow opener used in no-tillage system on micro environment of seed. American Journal of Agricultural and Biological Science 5, 1-6.

TEASDALE JR \& MOHLER CL (2000) The quantitative relationship between weed emergence and the physical properties of mulches. Weed Science 48, 385-392.

THEISEN G \& BIANCHI MA (2010) Low-disturbance sowing: a weed management tool in corn. Planta Daninha 28, 93-102.

VANBEEK KR, BRAWN JD \& WARD MP (2014) Does no-till soybean farming provide any benefits for birds? Agriculture Ecosystems and Environment 185, 59-64. 


\section{Chapter 6}

\section{General Discussion}


Many regions around the globe suffer from the threats represented by the expansion of agriculture over the natural environment. Agricultural expansion historically has been one of the major causes of losses in biodiversity. Until the beginning of the $20^{\text {th }}$ century, global increases in food production were primarily realised through expansion of agriculture at the expense of natural vegetation. Given the concerns about biodiversity loss and associated losses in ecosystem functions, there is major concern about further conversion of natural vegetation and landscapes into agricultural production fields (Coutts \& Hahn, 2015; Bucher, 2017). Still there is the challenge of producing around 60 percent more food for the projected world population of 9 billion persons by 2050. Attaining this production goal without further largescale conversion of lands into agriculture obviously requires intensification and increases in crop productivity per unit area (Sadras et al., 2015). Hence, current day agriculture faces the challenge to concomitantly increase production, optimize resource use and preserve nature.

The general objective of the study summarized in this thesis is to understand how to proceed in achieving a higher sustainability of lowland farming systems in Southern Brazil. As repeatedly mentioned throughout this thesis, these wetlands are strategic for Brazil's food security. Compared to the large area of food crops in Brazil, rice is only produced in a relatively small region, but it is this region that produces around $60 \%$ of the energy intake by Brazilians. Currently, irrigated rice is used as a main crop in the lowlands, but it only occupies about one third of the available fields, the rest being mostly left fallow. Improvements in lowland agriculture would not just enlarge food production and reduce pressure on land (Lapola et al., 2014), it would also promote regional welfare and prosperity. Besides these points, the southern Brazilian wetlands also represent an important reservoir of fresh water and comprise one of the main hubs of migratory birds within the entire American continent (ICMBio, 2014). Protecting natural wetlands, by optimizing the use of the land already in agricultural use, is thus needed. In this chapter, the main results obtained in the field experiments will be synthesized, their implications discussed and some projections based on the outcomes will be presented. Before that, some considerations about the most significant innovations resulting from this study will be discussed.

\subsection{Five important innovations}

This thesis presents five main innovations related to lowland agriculture in Southern Brazil. I briefly review them here, focussing both on their scientific and technological novelty and on the extent to which they are technologically and economically suitable for adoption. The 
question I address is whether these innovations have a real potential to improve the sustainability of lowland cropping systems.

The creation of cropping systems based on large ridges in the wetland paddies deserves being mentioned as the first innovation. The idea of a farming system containing only rainfed crops in lowlands can be intriguing for some people, since irrigated rice has been the traditional crop in this environment: cultivated for over a century in the south Brazilian paddies, and for thousands of years in many Asian countries. Evidently, rice is the physiologically best adapted crop and therefore the logical choice for the lowlands. The creation of a ridge-based system is aesthetically interesting and the concept breaks apart some paradigms about agriculture in wetlands. In my view, however, the big leap from adopting ridge-based systems ensues from the implementation of good management techniques, especially those practises associated with conservation-agriculture (CA). This entails the simultaneous use of no-tillage, winter cover crops, crop rotation and crop-livestock integration, which are considered the technological pillars of Conservation Agriculture (de Freitas \& Landers, 2014). In hydromorphic flat soils, this combination is almost only possible in a system that keeps the soil permanently dry, like the ridge-based system. In this thesis (chapters 2 and 3) these practises were combined and used to compose a whole new cropping system for the lowlands. Importantly, this investigation was not limited to a one-season demonstration plot, but constituted of a robust, large-scale rotation system maintained for more than nine years. The importance of the knowledge generated in this study is not limited to the south-Brazilian lowlands. The ridge-based concept can be useful to a much larger area, like the 13 million ha of irrigated rice fields in Asia, which are predicted to face increasing water scarcity in coming decades, and still lack viable alternatives (Tuong \& Bouman, 2003).

In addition to the major innovation represented by the ridge-based model, it is possible to highlight some important characteristics inherently related to these systems. The three most significant improvements in this sense are: a) the maintenance of a grain-based cropping system for almost one decade in a hydromorphic soil, without any intensive soil preparation; $b$ ) the massive production of pastures, and especially of cover crops, during the winter in a temperate wetland; c) the net accumulation of carbon into the soil while producing more food per unit of land than the regional averages (Item F in the Supplementary Information section). Together, this led me in chapter 2 to refer to the research on the ridge based model as the birth of a new cropping system. The results obtained in our long-term experiment strengthen the idea that the ridge-based model could be a good alternative system in lowlands. 
The second innovation is more at a scientific level and entails the comprehensive longterm evaluation and comparison of widely different cropping systems. Novel systems such as those based on the ridge-based models are not common in the scientific literature, since they represent a relatively new concept in the lowland environment. In chapters 2 and 3 these cropping systems were ranked over five distinct dimensions of sustainability and examined using approximately forty indicators. Hopefully, this work can contribute to future studies. At the same time it might support farmers in their operational and strategic decision making.

The third innovation, which can be considered an extension of the previous one, alludes to the framework designed to analyse the cropping systems. Taking into account the diversity of views on how to compare farming systems (Bockstaller et al., 2009), the distinct approaches which can be used (Clarke et al., 2017; De Luca et al., 2017), the lack of published results for similar systems, and the large volume of available data from our experiments, it was decided to develop a new way to analyse these systems. Inspired by two methods of system analysis used in the field of Systems Engineering and Business Intelligence, the cropping systems were decomposed into logical processes (Process Analysis) and the outcomes summarized into five key-performance indicators (KPI), each associated with a distinct dimension of sustainability. Through this approach an assessment and a fair evaluation of the different cropping systems could be made. Despite the apparent complexity of the method, it is flexible and can be adapted to analyse other cropping systems.

The use of a knife-roller to completely substitute plough and harrow to prepare the lowland soil is considered the fourth novelty presented in this thesis. The method is an easy, fast, and economic way to prepare the paddies for the next growing season after rice harvest. We showed that, compared to the conventional plough-based method, the roller-based technique saved a consistent amount of fuel and time (chapter 4). As a result of using this technique, soybean production, cultivated in rotation with rice, was improved, as for each unit of soybean produced, greenhouse emissions were reduced by one-fifth. At times in which production costs, labour and environmental impact from agriculture have to be optimized, this technique represents a valuable contribution. Knife-rollers are already used in agriculture (e.g. to terminate cover crops). However, the specific form of utilization we worked on, where the knife-roller was not complemented with any other soil operation for preparing the seed bed, is new and showed to be functional in a watered paddy. Since rice is the main staple for a large part of the world population, and the described method, because of its simplicity and low cost, is suited to any class of farmers, it is a technique with a huge potential application area. 
The fifth innovation refers to the invented equipment which is attached to no-tillage seeders. The ski (Figure 1; Chapter 5), was originally projected to allow that no-tillage seeders could be smoothly used in fields with a large amount of straw on the soil surface. The ski improves the cutting system of seeders, preventing operational stops to disentangle plant residues hooked below the seeder. The equipment also improves seed-soil contact and reduces soil erosion within the crop row. In fact, the ski was devised to improve Conservation Agriculture-based systems. What we observed, however, is that the benefits of this equipment were much larger than the effects originally planned. By attaching the skis to a no-till seeder, we reproduce what is known as the theoretical invisible no-tillage or invisible seeding (IAPAR, 2002), in which the mulching layer on the top soil remains intact despite the seeding, thereby protecting the soil and serving as a natural barrier for weeds. In fact, as reported in Chapter 5, weed seed germination was significantly reduced when this equipment was used. In parallel, we also tested one of the simplest ideas to minimize weed germination in no-tillage fields: reducing the speed of crop seeding. It was interesting and meaningful to observe that a lower seeding speed reduced weed density and biomass with almost half, in comparison with seeding at high-speed. Using a non-adapted seeder, soil disturbance and weed seed germination steadily increased with seeding speed. In contrast, the ski-seeder allowed to seed at a high speed, maintaining perfect seeding rows. It is needless to reiterate the operational gains from these findings, but the contribution to weed management is an important issue, especially for notillage fields, which are already criticized for their large reliance on herbicides (Giller et al., 2009; Meena et al., 2016). An advantage of simple concepts like low-speed seeding and the ski is that no-tillage seeders are used in many farming systems, both in lowlands and uplands, and for several crops. The benefits from this invention can thus be taken up by many distinct farmers.

\subsection{Agricultural use of south-Brazilian lowlands: are we wasting land?}

Currently the lowlands in the extreme south of Brazil represent a stable area of around 1.1 million ha of irrigated rice and approximately 0.35 million ha of soybean. The extent of maize and sorghum is low and declining, and almost no other grain crops are regularly cultivated in the hydromorphic soils. Lack of tradition regarding crop diversification, soil-related restrictions and other difficulties are common causes of a reduced number of crops cultivated in lowlands (Figure 12; Chapter 1). In most years, however, the climatic conditions in south Brazil allow the cultivation of more than one crop in the period of one year. Supply of water, temperature 
and solar radiation do not represent a severe limitation for an extended use of paddies through winter (data presented in Item C, in the Supplementary Information section).

In most upland fields in south Brazil, both summer and winter seasons are used to cultivate cash crops, pastures or cover crops. Agricultural production, from a time-related point of view, is really intensive and diversified. By contrast, in the lowlands the use of land is very different: the main crop (irrigated rice) uses only around $1 / 3$ of the available paddies ${ }^{1}$; grain crops are cultivated only during summer; and the predominant rotation (rice-fallow) is normally schemed to cultivate two or three seasons of rice, with a similar (or longer) interval in fallow after this period. Other crops, like soybean, maize and sorghum are present in no more than 1/5 of the remaining areas during summer. If we include the potential to cultivate part of the fallow fields in winter, the underuse of land is even more striking: use of the lowlands with rainfed crops drops to no more than $15 \%$ of the available area.

It is evident however that not all of the estimated 4.4 million ha of flat soils in the extreme south of Brazil (Figure 6; Chapter 1) can be used for grain-based agriculture. Some areas are protected (e.g. along rivers and lagoons), many flat fields are used only for livestock production, a part consists of urbanized areas and several regions contain lowlands which are permanently preserved (the Legal Reserves and the Environmental Reserves). For this reason, it is reasonable to assume that the current area available for cultivation in lowlands corresponds to around 3 million hectares. This estimate is close to what was previously reported in other studies (Baldi \& Paruelo, 2008; Giordano, 2014) and coherent with the observation that irrigated rice, with an area of 1.1 million ha, is cultivated in just one-third of the area already structured for irrigation.

Obviously, the exploration of all this potential is not just a technical matter, but depends on other, mainly social, factors. One question may be, for instance, whether the farmers wish and are able to successfully practise, in the short-medium term, a different form of agriculture in the wetlands. Furthermore, the problem of optimizing land-use in southern Brazilian lowlands is influenced by national and even international factors. Brazil is one of the biggest players in the international food market, the world demand for agricultural products is increasing, and we thus need to use the available agricultural lands in the best possible way. Overall, the evidence provided by: a) official statistics, for the area of land and crop production

\footnotetext{
${ }^{1}$ For several reasons, farmers are not increasing the area cultivated with rice. Water limitation and logistics are important factors. Economics (price of rice) and the need to move to another field after a maximum of three years of rice cultivation (auto-inhibition, soil fertility, diseases and weeds) also contribute to this.
} 
(IBGE, 2017); b) the RS Rice Institute (IRGA), for rice cropping systems (IRGA, 2017), and c) our own measurements on the use of fields within a cropping system (Figure 2; Chapter 2), indeed indicates that we are wasting part of the lowlands, by not practising grain-based agriculture in a larger area of the already cleared fields. Neither all farmers, nor all areas are prone to receive intensive systems in the short term, but a large potential productivity definitely exists. The results obtained with the ridge-based systems confirm this.

\subsection{Starting new cropping systems}

In south Brazil, irrigated rice integrated with extensive livestock production has been the main form of agricultural exploitation of the lowlands for more than one century. The dominance of rice-livestock systems is a product of historical factors, as the arrangements on land possession and use, the natural adaptability of rice to the wetlands, the importance of livestock for the regional economy and the technical complementarity between these two activities.

Interestingly, none of these factors that supported rice-livestock systems in the past have significantly changed until today: land use for rice production still is mostly based on rented fields; rice still is the unique large-scale crop fully adapted to highly water-saturated soils; livestock production still is an important regional activity, and cattle still can benefit from rice cultivation and vice-versa. Seen from this angle, the agricultural systems in lowlands need not be modified. Lowland agriculture, however, has indeed faced several changes in the last decades. The most important change is represented by the large expansion of soybean and the improvements in rice production technology, which have made farmers produce more food per unit of land. Irrigated rice, for example, increased from $3.5 \mathrm{Mg} \mathrm{ha}^{-1}$ in the 70 's to $5.3 \mathrm{Mg} \mathrm{ha}^{-1}$ in the 2000's, attaining around $8 \mathrm{Mg} \mathrm{ha}^{-1}$ in the 2016/17 cropping season. Thirty years (19702000) were needed to increase yields with $50 \%$, but more recently, the same gain was realized in almost half of that time.

Irrigated rice yields have increased to unprecedented levels in south Brazil. This trend is still underway, and does not appear to level off. New technologies are continually offered, farmers can improve production techniques, and use of external inputs keeps on increasing. High grain yield is seen as a universal objective in agriculture (Lin \& Hülsbergen, 2017), and this is not different in the lowland environment: it is naturally pursued by farmers, scientists, and especially instigated by supply companies. Many extension programs issued in the southern Brazilian lowlands have clearly associated yield-goals, like "Project 10" -that aims to achieve $10 \mathrm{Mg} \mathrm{ha}^{-1}$ of rice, "Soybean 6000 " -that aims for $6 \mathrm{Mg} \mathrm{ha}^{-1}$ of soybean, and similar others 
projects, that commonly are based on a heavy package of inputs. Whilst very efficient in enlarging crop grain yield, many of these commercially-based programs fail when critically assessed regarding environmental impact or monetary risks, of which the burden is commonly put on the farmer's back only.

It is important in this regard to take note of the fact that grain yield is only one aspect of sustainability. The current way of practicing intensification has undoubtedly promoted production, but it also has been accompanied by unwanted side-effects in the lowlands. Residues of pesticides found in water is an important concern in this sense (Marchesan et al., 2007; Silva et al., 2009; Refatti et al., 2017). At the same time, the increasing spread of herbicide resistance in weeds constitutes an increasing problem (Porto \& Soares, 2012; Goulart et al., 2014). Despite the recent technical improvements, the high yields in crop production have been obtained at the cost of a high amount of energy, especially for rice (Ferreira et al., 2014). High risks of financial losses and low margins per hectare related to the high costs of inputs also characterize these intensive systems (Barata \& Toledo, 2015; CONAB, 2016).

Yield gaps caused by short-term constrains, like pests, a limited soil fertility and soil compaction, are commonly reduced with short-term solutions, like pesticides, fertilizers and soil preparation (subsoiling). This is nothing new and commonly practiced in intensive agriculture. However, evidently the same kind of problems have been repeatedly solved in the same way, year after year. An additional issue is that as crop yields become higher, the sensitivity to these yield-restrictions become equally higher, making the systems more and more dependent on these external inputs and practises.

The lack of durable and more robust improvements in the lowlands becomes apparent when long-term trends on the quality of the soil are analysed. Most lowlands in the RS state are poor in terms of nutrients and organic matter. The rice-based systems, despite a relatively high annual biomass input into the soil $\left(\sim 7 \mathrm{Mg} \mathrm{ha}^{-1}\right)$, have not managed to increase their level of soil organic matter (Boeni et al., 2010). Organic matter is one of the most important components of soil quality, since it provides better structural (Johannes et al., 2017), biological (Sapkota et al., 2012; Finn et al., 2017) and chemical (Fageria, 2012) characteristics. The seasonal alternation between dry and highly water-saturated soil conditions affect the carbon dynamic in the soilatmosphere interface, resulting in a limited storage of C as organic matter (Kirk \& Olk, 2000). This could explain the low levels of soil organic matter in the rice systems in the RS. To buildup SOM in the paddy fields and to obtain the benefits related to such an increase, other forms of soil management are needed. 
Changes in the lowland agriculture can also lead to large-scale benefits outside of the farms, since wetland areas play a significant role in regulating C-dynamics and greenhouse gases in the atmosphere. Besides carbon accumulation, the emission of waterlogging-associated greenhouse gases, like methane $\left(\mathrm{CH}_{4}\right)$, would be reduced if the lowland fields would be maintained dry for a longer period of time (Ono et al., 2015). In the same way, emissions of nitrous oxide $\left(\mathrm{N}_{2} \mathrm{O}\right)$, an even stronger greenhouse gas than methane, would be reduced, since this gas is produced in high quantities when the soil is submitted to alternating regimes of drying and water-saturation (Silva et al., 2013). Irrigated rice obviously requires water on the soil surface and the rice-paddies are a source of GHGs. But for this case, it is worth to mention that most farmers are constantly managing to optimize water use in rice to reduce costs (do Amaral \& Righes, 2005), improvements which potentially also minimize GHG emissions (Khosa et al., 2011). The point is that the large parts of the fields that remain fallow are usually subjected to waterlogging or to alternating regimes of dry- and water-saturated soil. For these areas, alternative cropping systems, like the ones represented by the ridge-based systems, can contribute to an increased provision of global environmental services. This contribution was indeed attested in our long-term experiment, where we identified that the ridges-based systems were able to convert "carbon-emitting lands" into "carbon-sequestering lands" (Chapter 2).

Up to now, the question whether new farming systems are needed has been discussed in relation to aspects of current intensification and from a point of view related to soil quality and environmental impact, using soil organic matter and carbon-GHG dynamics as examples. The arguments discussed were used to express that new cropping systems are needed and could be useful to improve both short- and long-term sustainability in the southern Brazilian lowlands. Although this discussion has been limited to south Brazil, similar problems have been reported for lowlands all around the world, especially in Asia (Garrity et al., 1990; Durno et al., 1992; George et al., 1992; Bijay et al., 2008).

As repeatedly stated throughout this thesis, just a fraction of all arable land in the wetlands of RS is used for crop production, and of the remaining fallow fields, many could be utilized for agriculture. Important in this context are the differences in development between the northern and southern regions within the RS state. Differences which are, in large part, connected to agriculture. Whilst the north has various crop and animal production systems, generating a continuous flow of jobs and welfare, diversification in the south has been limited, particularly by continuing to base agriculture on almost the same foundations as in the past. Such a diversification of agriculture in the south could help to bridge the gap in development 
between North and South within the RS state.

Looking critically, the recent increase in agricultural production in the South of RS have much relied on the old recipe of realizing a higher production by enlarging the cultivated area (e.g. soybean) and by using more inputs. Undoubtedly, this strategy enlarges grain production but it is not sufficient to increase sustainability in a long-term perspective, as our data indicate (e.g. soil quality). The same issue has also already been discussed by other scientists (Tilman et al., 2002; Foley et al., 2011). Currently, field-specific problems are mainly being solved with short-term solutions, like the use of pesticides to control annual weeds, subsoiling to minimize soil compaction, and the use of fertilizers to overcome the chronic low soil fertility. Short-term problems obviously need to be resolved promptly, but they can be prevented, alleviated and better handled if a more integrated crop management is used.

Speculating the future, it can be envisaged that the current difficulties for farmers will hardly be relieved by using the same methods or solutions currently in use to defeat them. In my view, and based on the outcomes of our experiments, build-up of lowland sustainability requires a certain level of 'thinking outside the box'. In that sense, the introduction of alternative farming systems, like the concept of the large-ridges, enabling grain crop diversification and a larger production of pastures and cover crops, seems a good alternative.

\subsection{A brief discussion on the methods used to address the research questions.}

In the context of this general discussion, it is valuable to consider some issues related to the long-term experiment that was done for this thesis. Three topics were selected, which can help to explain the choices which were made regarding our experimental design.

\section{a) Why were three rice-based systems selected?}

Rice-based systems represent the principal form of agriculture in the south Brazilian lowlands. They are currently found in two main arrangements (Figure 7; Chapter 1). The predominant rice-and-fallow, which accounts for almost $70 \%$ of area cultivated with rice, and the models in which rice is rotated with another crop, predominantly soybean. A long-term experiment conceived to understand the lowland production systems could not, logically, leave these models out. It is interesting to note the multiple ways in which two crops and one livestock class (beef-cattle) can be combined in different production schemes; a situation that is happening in the paddies of RS. 
The way the current cropping systems are temporally arranged and how they are managed depends on several factors, for instance the presence/absence of cattle in the field during the winter, the cattle stock rate, the vegetation during fallow (spontaneous or sown), the type of rice cultivar (e.g. Clearfield ${ }^{\circledR}$ or other), the method of soil preparation (conventional or minimum-tillage), the difficulties encountered to keep the paddy drained, and others issues. It is impossible to evaluate all these arrangements experimentally on farm-size plots with a precise and long-term registration of all field activities. Hence, there was no other option than to restrict ourselves and chose the three most representative production models based on irrigated rice at the time the long-term experiment was initiated: a minimum-tillage rice-fallow, and, evolving from the first, rice rotated with soybean, in conventional tillage and minimum tillage.

b) What is the meaning of a statistical comparison between yields obtained under strict experimental conditions and the average yield of a region composed of a much wider range of environmental and management conditions?

This comparison, presented as Supplementary Information section (item F), has indeed a significant meaning. The soil on which the experiment was conducted belongs to the same class as over 2.5 million hectares of land in the extreme south of Brazil and, consequently, many common characteristics between these areas, like a relatively poor fertility, frequent waterlogging and a challenging physical soil structure for upland crops, exist. The management applied in the experimental rice-based systems - e.g. cultivars, crop nutrition, pest control, field and irrigation practises, and machinery operations- mimicked common farmer practices. Each system was laid out in a large-plot scale, on which effects of machinery operations and water consumption could be measured at a relevant scale. We based the management on technical recommendations provided by the official institutions working with rice, maize, soybean and soil in south Brazil. To summarize, each cropping system was implemented in a realistic way at a scale and in a manner as if it represented an independent farm.

Despite all these efforts to reproduce what is done under actual farm conditions, it is important to check the extent to which our findings are representative for real farm conditions. For this reason, we checked whether the experimental grain yield fell within the range observed on farms. This was indeed and very consistently the case over 9 cropping seasons. The presented results suggest that the measurements of other indicators in the experiment, for which we did not do the same check, were also representative for real farm conditions. 
c) Is it fair to compare very different production models, like the rice-based and the ridge-based systems?

An assessment of cropping systems is needed, even though a fair comparison between systems that differ substantially is not a simple task. Obviously, the ridge-based systems received a very distinct soil management compared to what is commonly practised in flat soils, represented by the three rice-based systems. However, similar to the criteria used to define the rice-based models, the systems conducted on ridges were also designed taking account of regional demands and the technical possibilities for farmers to implement these systems. For example, no other equipment is needed to build and to cultivate the ridges than the machinery already used in rice-soybean rotation. In addition, these novel systems also were planned to represent two coherent alternatives: both producing cash-crops in summer, but one model prioritized winter cover crops intending soil improvement, whilst the second model focused on croplivestock integration, in attention to farms with livestock activities and to explore the known benefits of this integration (Martin et al., 2016). We still sustain our selection of cropping systems, as they cover a wide range of social, economic and technical interests, and range from standard practices till innovative systems that are not commonly practiced yet. The benefits of the ridge-based systems on rainfed soybean and maize was overwhelming when compared to the regional standards, but these large differences in productivity do not undermine the validity of the comparison between the cropping systems.

Production per unit of land is one of the most powerful metrics in agriculture, as it integrates a number of agro-ecological and management factors. However, a fair comparison between systems should not be limited to yield per unit area (Bockstaller et al., 2009), since other factors like nutrients, labour, money and even system resilience can be limited (Leng, 2008). For a reasonable and fair evaluation, a joint assessment of multiple cropping systems requires a multi-criteria approach (de Olde et al., 2016; Hammond et al., 2017; Peral et al., 2017). In accordance with this philosophy, we purposely put each cropping system on a fieldsized scale, to minimize extrapolation errors (Fresco, 1995). Additionally, we based the analysis on nine consecutive years of experimentation, rather than on just two or three years. We also used a large range of indicators distributed over five dimensions of sustainability, and finally, we provided a detailed presentation of each of the investigated systems (in Chapters 2 and 3 and the Supplementary Information section). In this way, the comparison between the different production models was made transparent and as fair as possible. 


\section{What more do these results indicate and allow to discuss?}

As stated before, crop productivity from each cropping system was tested against the regional standards. In the rice-based systems, rice and soybean grain yields did not differ from the regional yields. This is not surprising, since crop management in the experiment was similar to what farmers normally do. In contrast, the systems conducted on ridges yielded more than the regional averages for soybean and maize. In these systems especially maize benefitted, with Ridges and Cattle presenting an apparent advantage over Ridges and Cover crops.

Simply comparing crop production per unit area does however not suffice for an adequate evaluation of land use efficiency (LUE). Some authors, as Lin and Hülsbergen (2017) and Seufert et al. (2012), rightfully argue that LUE should also consider the time the crops are occupying the field. A criticism regularly put forward to the predominant model of rice production in southern Brazil refers to the large part of areas remaining fallow, as depicted in the Figure 2 (Chapter 2). Metrics like crop grain yield commonly ignore the crop cycle and, in case of the south Brazilian lowlands, also ignore the time during which the fields are kept fallow. A different perspective on this last issue can be discussed though. Although time has, essentially, no limits, the demand for agricultural products cannot wait forever to be supplied. From this simple point of view, time is clearly a limiting resource and its use should be optimized. Also important, the utilization of resources like water in irrigated systems, and the exposition to constraints like pests or natural disasters, are all affected by time. If we take the interaction between land use and time into the account in the calculation of agricultural efficiency, the land-time-adjusted grain yield for rice in the RS state will drop from $8 \mathrm{Mg} \mathrm{ha}^{-1}$ per cropping season to around a mere $3 \mathrm{Mg} \mathrm{ha}^{-1}$, or to $3.6 \mathrm{Mg} \mathrm{ha}^{-1}$, as obtained in the experimental Rice-Fallow system, in which rice was only grown in $50 \%$ of the seasons. That is a large and important difference, which often escapes the perception of people. Actually, it is one of the hidden costs of maintaining the things as they always have been.

In addition to harvestable yield, total biomass production is a measure used to define agricultural efficiency in a broader ecological perspective (Boehmel et al., 2008; Jane Dillon et $a l ., 2016)$. Crop residues after harvest, which were considered a problem until the recent past, nowadays are perceived as a valuable contributor to more sustainable systems (Alary et al., 2016) and as a potential source of marketable co-products, like cellulose (Sharma et al., 2017), biofuels (Wang et al., 2014) and feed stock (Stein et al., 2015).

From an agronomic perspective, stubbles from harvested crops and residues from other 
species placed on the top soil can interfere in the cropping system in multiple ways. Most of the times these residues are beneficial for the agricultural fields, particularly those in subtropical and tropical regions (Gill \& Jalota, 1996; Thierfelder et al., 2013). Many of the results obtained in the ridge-based systems, like the increase of soil organic matter, the positive balances for $\mathrm{P}$ and $\mathrm{K}$ in soil, the high water productivity and the excellent performance of the four $\mathrm{CO}_{2}$-e based indicators, can be largely attributed to a high production of biomass in these systems. These findings are in agreement with those of Rosolem et al. (2016) and Siqueira Neto et al. (2009). In this case, the production of cover crops and pastures during the winter made up for these large differences (Figure 3; Chapter 2). Additionally, the stability of the hydraulic status of the soil is an important factor that needs to be taken into account. Repeated wetting and drying of soil, common in flat wetland soils, leads to an increased mineralization (loss) of carbon from the soil (Ghimire et al. (2012) and Kirk and Olk (2000). The format in which ridges are built, with the water temporarily accumulated only in small channels between the $8 \mathrm{~m}$-spaced ridges, prevents waterlogging and the frequent changes in the soil hydraulic status for most part of the field. This condition, as already discussed, contributes to a consistent accumulation of carbon and organic matter in these fields.

\section{Biomass, energy and sustainability of lowland cropping systems}

An interesting way to visualize and compare cropping systems is by converting all the processes and materials (inputs, outputs and labour) to energy units. This approach is commonly used in Life Cycle Analysis (Garrigues et al., 2012) and also provides a convenient way to assess and understand the differences between distinct farming systems (Bockstaller et al., 2009). Figure 1 summarizes the fluxes of energy entering and exiting the cropping systems, in a format of Sankey flow's diagrams (Soundararajan et al., 2014). These diagrams, on which the size of all elements is proportional to the amount of energy they represent, were didactically separated in two parts, with "short term benefits" on top and "long term benefits" at the bottom. Short term benefits represent the energy contained in food, whereas long term benefits refer to the energy contained in all the remaining non-food biomass, providing improvements for the cropping systems in a long-term sustainability perspective.

The cropping systems in Figure 1 were grouped in three main categories: rice-fallow (A), rice-soybean systems (B) and the ridge-based systems (C). A visual inspection of these diagrams reveals that the major differences between the systems are not in food production, but in biomass production. From this energy-based perspective, the flows presented are rather clear: 
large part of the energy aggregated by the ridge-based models is channelled to improve the cropping system, via the production of biomass. Since crop residues and other sources of biomass constitute the most important foundation to increase soil organic matter, a virtuous cycle of sustainability is created in the ridge based systems, as is also evident from the soilquality and carbon-balance perspective (Chapter 2).

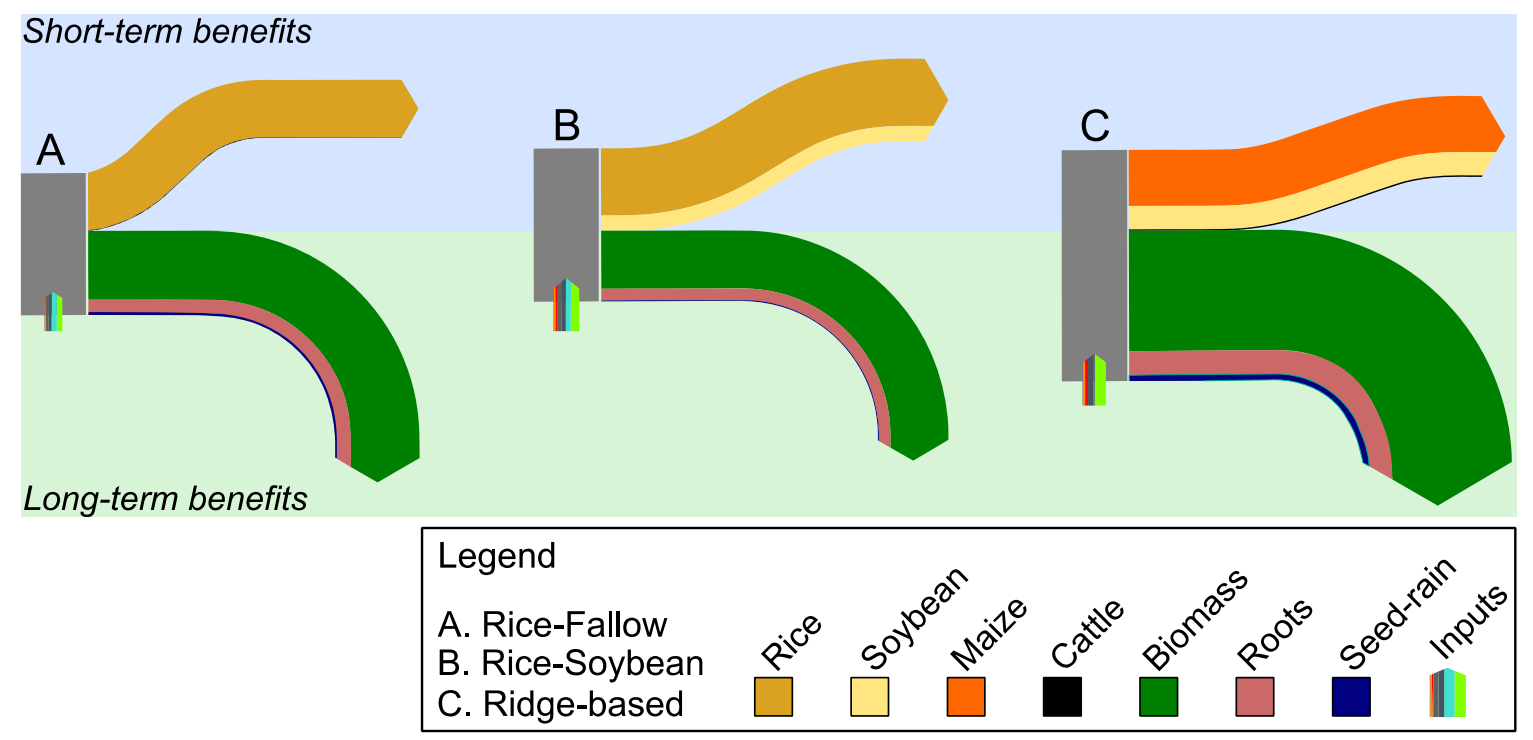

$\underline{\text { Numerical data (values in GJ ha }}{ }^{-1}$ )

\begin{tabular}{lccc} 
& \multicolumn{3}{c}{ Cropping Systems } \\
\cline { 2 - 4 } Inputs & Rice-Fallow (A) & Rice-Soybean $(\mathrm{B})^{1}$ & ${\text { Ridge-based }(\mathrm{C})^{1}}^{1}$ \\
\cline { 2 - 4 } & $15.1(4.0)$ & $21.4(1.8)$ & $19.2(1.1)$ \\
\hline Rice & $117.0(4.2)$ & $118.0(4.0)$ & - \\
Soybean & - & $36.5(1.7)$ & $42.3(1.4)$ \\
Maize & - & - & $106.7(10.5)$ \\
Cattle & $0.52(0.14)$ & - & $2.0(0.2)$ \\
\hline Aerial biomass & $69.9(3.4)$ & $59.4(2.7)$ & $123.3(2.5)$ \\
Roots & $14.0(0.7)$ & $11.9(0.5)$ & $24.7(0.49)$ \\
Seed-rain & $1.5(0.2)$ & $1.0(0.09)$ & $6.7(0.37)$ \\
\hline Total & 144.2 & 154.1 & 230.2 \\
\hline
\end{tabular}

1 'Rice-Soybean' refers to the averaged values of Rice-Soybean CT and Rice-Soybean MT, and 'Ridge-based' refers to the averaged values of Ridges and Cattle and Ridges and Cover crops.

Figure 1. Diagrams for fluxes of energy in cropping systems carried out in lowlands in south Brazil. Values represent yearly averages. Values between parenthesis are the SEM.

However, in contrast to harvestable products, biomass as such is usually not marketable. Hence, due to the absence of a direct economic gain and a weak perception about the longerterm benefits provided by the biomass, many farmers do not include the management of crop 
residues on their priority list when managing systems in lowlands. This will only change, if the farmers would become aware of the opportunities to increase long-term sustainability, as well as by presenting the economic values of these not-yet-valued benefits, like the environmental services. This idea indeed is already endorsed as a pragmatic strategy to communicate the societal value of ecosystems (Daily \& Ellison, 2003; Skroch \& López-Hoffman, 2010; Matulis, 2014).

Representing a technical benefit or an inherent characteristic of a cropping system in monetary values opens a discussion that leads to new insights. For instance, the stock of nutrients in the soil could be considered a valuable asset, since it represents potential savings when acquiring fertilizers. In a similar way, the importance of crop residues on the soil surface would be better appreciated by farmers, if indicators like water use-efficiency, positively affected by crop residues, would be presented in monetary units. Applying such a conversion for these two examples based on the data obtained in the long-term experiment is an interesting exercise. In the case of nutrients, the difference between the ridge-based and the rice-fallow systems for accumulated $\mathrm{P}$ and $\mathrm{K}$ (Table 4; Chapter 2) equals to an average credit equivalent

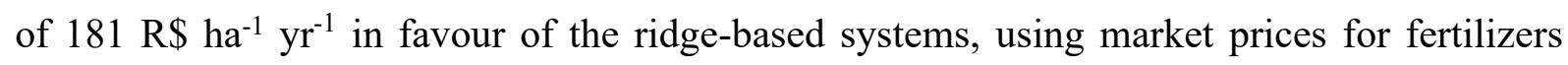
between 2012 and 2016 in the RS state ${ }^{2}$. Using a similar approach for water use-efficiency, each $\mathrm{mm}$ of precipitated rain returned an equivalent of $\mathrm{R} \$ 2.35$ in grains in the ridge-based systems (calculated from Table 7; Chapter 2), compared to $1.63 \mathrm{R} \$ \mathrm{~mm}^{-1}$ for the ricesoybean models and to $0.77 \mathrm{R} \$ \mathrm{~mm}^{-1}$ for rice-fallow.

It is comprehensible that this kind of indicator is not commonly reported in the scientific literature, but surprisingly, this type of data also rarely appears in more farmer-oriented magazines. Disclosing information that resonates with the dominant economic view is one of the most powerful methods of communication (Gómez-Baggethun \& Martín-López, 2015). Although unusual, this kind of indicator might be useful to disseminate sustainable agricultural practises and get farmers interested. At the same time such indicators might help scientists to better comprehend agriculture, and help them to improve the design of new farming systems.

\subsection{Is it possible to identify the best cropping system?}

Many people dream of the existence of a just and perfect farming system, in which top yields are always produced, the highest profit earned at each harvest, the environment not maltreated,

\footnotetext{
${ }^{2}$ This potential savings corresponds to $27 \%$ of the annual expenses for fertilizers in the ridge-based systems.
} 
and the societal demands fully supplied. This utopian ideal, however, is unrealistic. The current state of farming, what it should be, and what people think it should be are three different things. The answer to the question "what is the best farming system" depends on many things not in the least on whom you ask.

For example, for self-supporting farmers the best cropping system probably will be the one that delivers the highest and/or most stable yields. A more commercial farm will likely consider net incomes as the top priority, and such farmers will pursue this primarily by maximizing the use of land, labour or capital, whichever is most limiting. Yet another class of farmers with limited resources or credits certainly looks for smaller production costs, whereas optimization of labour is a priority where workforce is limited. Clearly, other possible demands and perceptions exist, and the concept of "best" varies, accordingly with the specific objectives and ideologies of the person involved.

An important shift is taking place in much of the thinking about production systems across the world. In the past, the main driving force to enlarge food production was to increase the yield potential of crops and their productivity. Today, the concept of productivity is progressively being combined with the desire and demands of sustainability (Singh et al., 2011). In Chapters 2 and 3 an exercise to comprehend and assess the sustainability of a cropping system was performed. This assessment was synthesized in the form of five Key Performance Indicators (KPIs), which in turn were each based upon a set of normalized primary indicators reflecting various aspects of the performance of a cropping system. The KPIs, a concept from the field of Business Intelligence, represent the pillars of an agricultural system, where each pillar is associated with what is known as a dimension of sustainability, following Jane Dillon et al. (2016).

The algorithm behind each KPI was designed in such a way that the most elemental agronomic result, as well as the more complex issues, for instance the capacity of a cropping system to deliver solutions for regional demands, was appropriately considered. For example, the KPI associated to environment purposely contained indicators associated with leaching of pesticides and $\mathrm{N}$-compounds into water, since water represents one of the most sensitive components of the lowlands. Similarly, the KPI associated to land productivity included not just production per area, but also the time that the fields were effectively used for agriculture, an important issue at regional level, explored in the section "...are we wasting land?". It is known that there are different opinions and approaches to evaluate farm systems' performance (de Olde et al., 2016; Himmelstein et al., 2016; Bucher, 2017). Also our framework, consisting 
of Process Analysis and Key Performance Indicators (PA-KPI), is shaped by previous experiences and expertise. We purposely selected a wide range of primary indicators and selected five KPIs to capture the performance of the systems at the best possible authenticity.

The graphs and tables presented in the previous chapters perhaps have already induced the reader to signify one of the studied cropping systems as the best. The radar plot of Key Performance Indicators (Chapter 3; Figure 9) could serve as a first guide to select the cropping system that best fits ones' needs. However, the information provided in this Figure is still not complete. A more comprehensive representation of the system's performance could be achieved, if more elements would be added into the analysis. For instance, the inclusion of topics like greenhouse emissions and carbon balance, which were not included in the analysis of Chapter 3, certainly would make the comparison more realistic. Thus in this General Discussion I used a wider list of indicators to calculate the KPIs (listed in Supplementary Information, item $\mathrm{H}$ ).

Appropriately comparing cropping systems is a challenging task, which commonly requires the use of site-specific, adapted algorithms and frameworks. Some statistical tools, however, can help to enlighten this task. One interesting approach is the Canonical Multiple Discriminant Analysis (Altman, 1968; Tabachnick \& Fidell, 2013), a statistical procedure which returns, from a group of several indicators, a relatively easy to interpret bi-dimensional graph, which presents the boundaries of similarity between the cropping systems.

The representation in Figure 2 does not present any evidence for a high or a low performance of a specific cropping system. However, it shows that two distinct groups exist, one being the three rice-based systems and the other the two ridge-based systems (Figure 2). Although it is not possible yet to point what is the best system, it is clear that there are substantial differences between these models of crop production.

\section{The singularity of a meritocratic approach}

The Key Performance Indicator approach is a straightforward way to summarize the overall performance of an agricultural system. The method created for the current analysis is original, since only the merits, or the benefits from a system are added to build the KPI value. In this meritocratic approach, no penalties are attributed if an indicator or a cropping system presents a weak performance. Instead, 'rewards' are given, with the largest premium (score $=1$ ) 


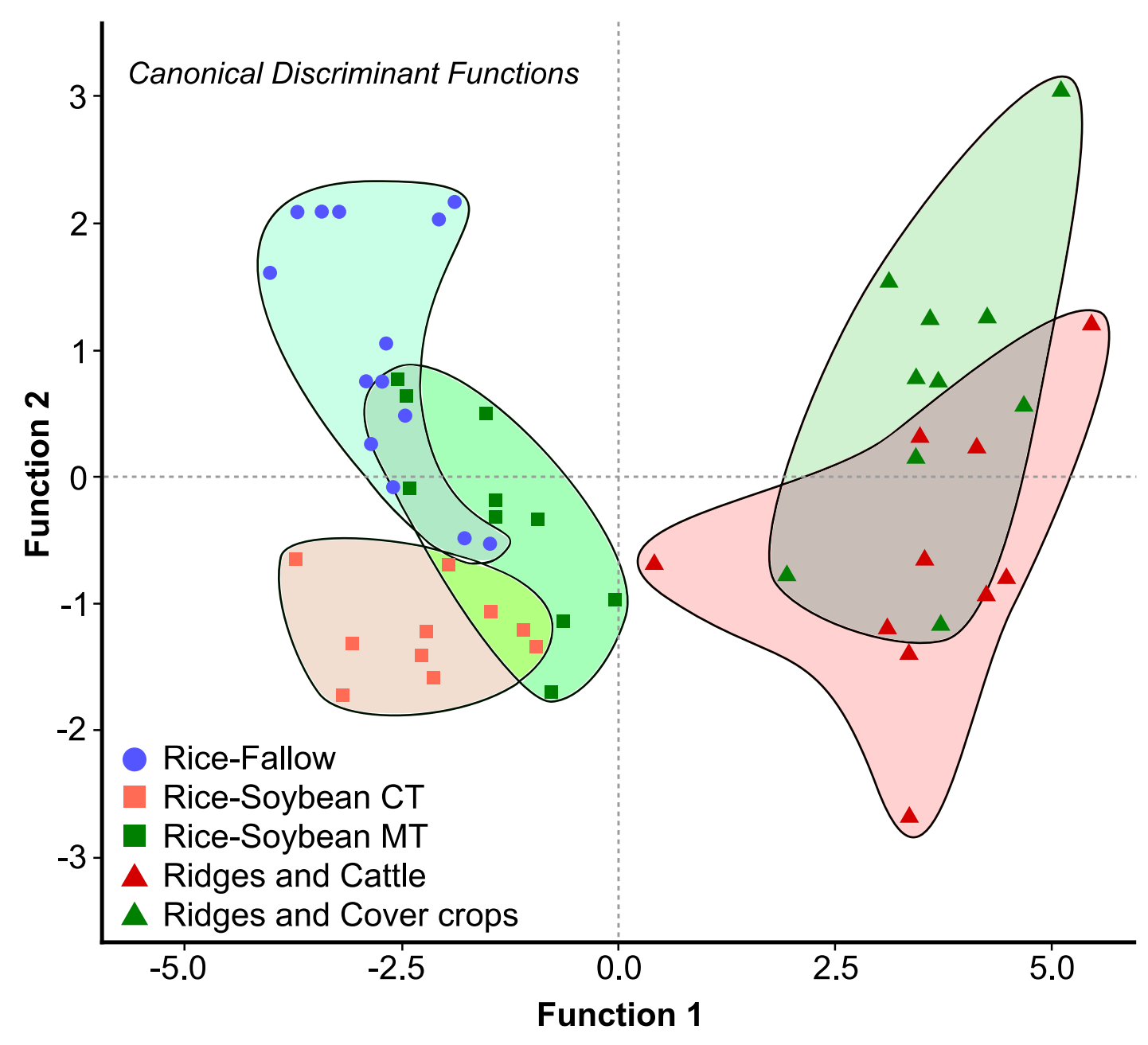

Figure 2. Scatter plot from a Canonical Multivariate Discriminant Function and respective domains of five cropping systems evaluated in lowlands of south Brazil (31 indicators originally included, listed in item H in Supplementary Information section).

attributed to the system which attains the best performance. Subsequent points are proportionally attributed to the other cropping systems. Used in this way, the instantaneous snapshot-KPI is able to identify the cropping systems in terms of their inherent relative capacity to deliver agricultural-related benefits. These benefits is what is mostly pursued. The higher the KPI value, the larger the benefits. The preceding steps, Process Analysis and the analysis of primary indicators, obviously are required to identify the reasons why a cropping system does not perform very well regarding some of these macro-indicators, and to understand the essence of these systems.

It is reasonable to imagine that, from a farmer's perspective, the most important KPIs are Land productivity, Economics and Environment. These issues lead to a straight association with agriculture and with the day-to-day worries of most lowland farmers. Our analysis, 
additionally, also encompassed Energy and Labour as key indicators. Whilst energy is a worldwide trending topic and the associated indicators help to better understand the systems, the inclusion of the Labour-associated indicators softly bends this analysis into a social perspective. Indeed, the indicators and respective KPI associated with labour help to explain some social changes occurring in the rural areas of the RS state. The reduction of workforce in the fields and the shift from simple production models in lowlands (e.g. Rice-Fallow) towards more diversified and potentially profitable systems (e.g. Rice-Soybean) are two clear examples.

Assuming a KPI as a numeric and concrete representation of the benefits delivered by a cropping system, it is possible to establish mathematical relations between these concepts, as well as to create a sort of ranking. It is obvious that the reduction of a relatively abstract concept into a numerical expression can be criticised (Riley, 2001; Dag Hammarskjöld Foundation, 2015). However, this kind of mathematics is explored in the field of functional analysis (Penot, 2016) and has been used in several areas of science (Nachbin, 1981; Van Geert, 2014). One of most simple examples of a functional analysis is represented by the addition of values of the Key Performance Indicators, as presented in Figure 3.

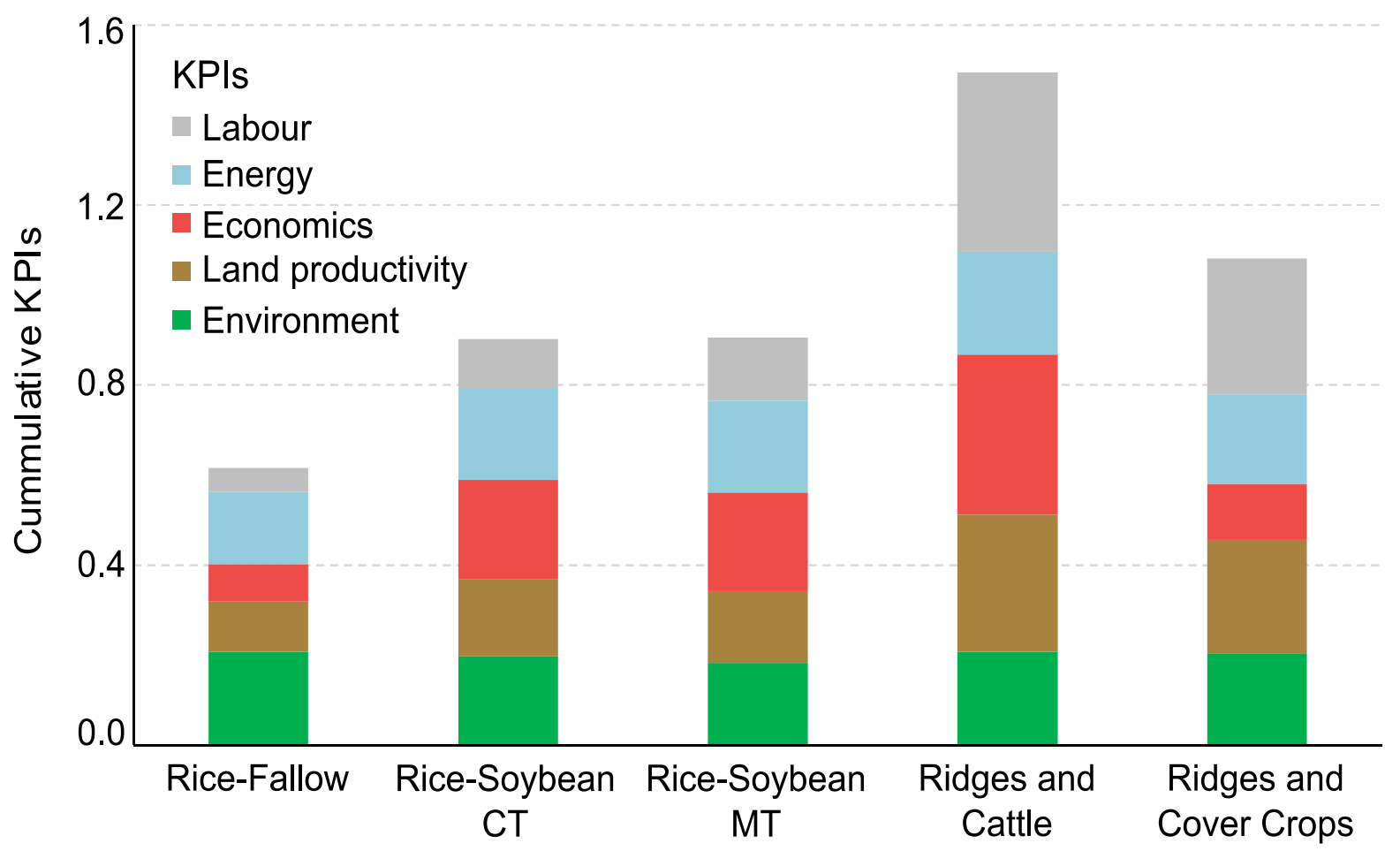

Figure 3. Key performance indicators for five cropping systems in lowlands of south Brazil. 
The representation of the KPI-values in the format of a cumulative stacked-bar diagram (Figure 3) makes a visual inspection across cropping systems relatively easy. In this case, Ridges and Cattle, the system based on crop-livestock integration, stands out positively among the evaluated systems. In contrast, the simplest model of rice production (Rice-Fallow) is the poorest performer of the group. A potential future improvement of this approach is to take the variation of the primary indicators into account. The higher end of the observed variability of a KPI could be used to set feasible targets for improvements within a cropping system.

This section has discussed the logic behind identifying the best cropping system, among the group of five models evaluated, using mostly the outcomes from the Key Performance Indicators. In fact, the KPIs, as well as the canonical discriminant graph presented in Figure 2, are a robust summary of the outcomes of 31 indicators collected along nine years of experimentation. The selection of these indicators and their arrangement within KPIs was aimed to represent the essence of the cropping systems and the relation of a cropping system with the physical, economic and social environment. Up to now, the apparent winner seems to be the system based on crop-livestock integration in the ridges. In fact, the good performance of this cropping system is similar to what was already found in several studies in which integration of crops and livestock was assessed (Martin et al., 2016; Martins et al., 2017). As in other studies (e.g. Balbinot Junior et al., 2009), the presence of cattle in the field seems to act as a catalyst, which brings clear benefits to the soil and, on the long term, to the whole cropping system. The deposition of manure, with a chain of healthy events at soil level, seems to be the key cause of these benefits (De Moraes et al., 2014; Martin et al., 2016).

Figure 3 depicted the KPIs in a very straightforward numerical way. But other more suggestive depictions can also be used and may be more persuasive. The dashboard-plot (Figure 4) is a good example in that sense, as it associates performance, to dynamics and movement. For the dashboard depicted in the next page, the values from each KPI in the respective cropping systems were modified to fit in the range of the gauge's pointers. Additionally, colours were added to the plots to reinforce the association with the benefits delivered by the cropping systems: red meaning a poor benefit, and green representing a good and desired benefit.

The dashboard is not intended to reverse the concrete representation of KPIs back into abstract concepts, neither is it presented just because of its beauty or because ordinary people can easily understand the underlying messages. This layout is a powerful way to illustrate interactions affecting the systems under evaluation, which also helps to explain and interpret events out of the experimental arena. For instance, it was repeatedly argued and discussed that 


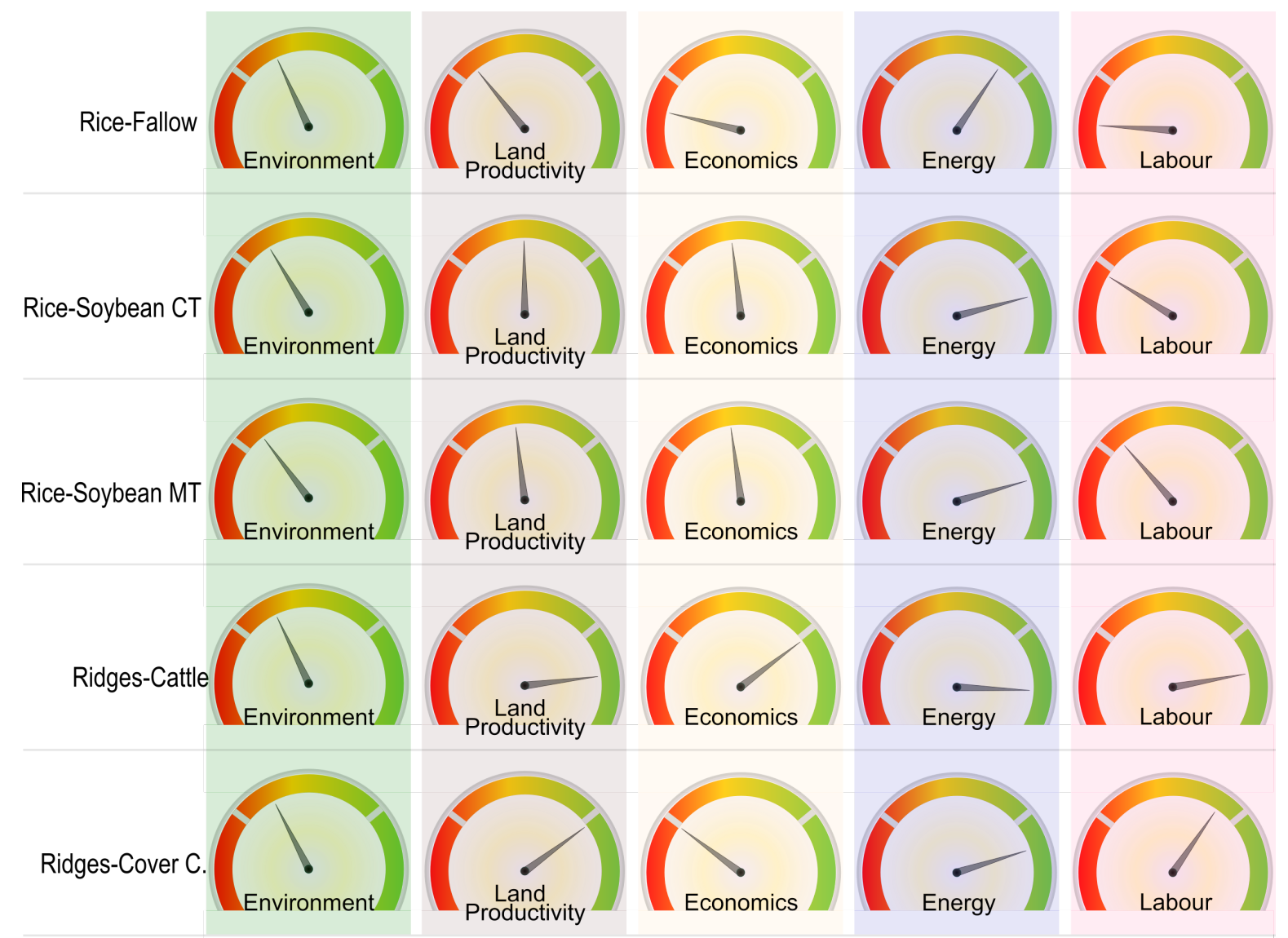

Figure 4. Dashboard-plot graph expressing five Key Performance Indicators for cropping systems in lowlands in south Brazil. The range of pointers was calculated from KPI values, varying from 0 , meaning a poor performance (red) to 1 , meaning a high performance (green).

Rice-Fallow is the predominant grain-based system in lowlands of south Brazil. It also was discussed that this simple model of production is being gradually substituted for some more intensive systems, like Rice-Soybean (Figure 7; Chapter 1). What is perceptible, and supported by official statistics, is that farmers are in fact moving from a system which delivers the lowest indexes on economics, land productivity, energy and labour-associated benefits, toward cropping systems which offer a better perspective for these issues. A mere inspection of the three initial rows of gauges shows these differences: the adoption of rice-soybean rotation represents consistent improvements for issues connected to the immediate interest of farmers, at a slightly higher environmental cost.

From an environmental perspective, the pros- and cons- of both Rice-Soybean cropping systems are very similar. Obviously, Rice-Soybean is not neutral regarding environmental impact. The technology presented in Chapter 4 also shows that soil-preparation can be improved. Similar adjustments in other areas could also help to further improve this system. 
However, for a more ambitious leap towards sustainable intensification, new concepts are needed. In that sense, a cropping system like Ridges and Cattle, as the dashboard reinforces, is a good alternative.

\section{Balances \& counterbalances}

The primary indicators described in Chapters 2 and 3 already revealed some trends and specificities of the cropping systems, independently from the calculated Key Performance Indicators. These outcomes fuel an additional but interesting discussion that sustainability assessments depend heavily on the measures used. For instance, in Chapter 2 it was shown that ridge-based systems performed well in terms of carbon balance and greenhouse gas emissions, if compared to rice-based systems. But they also involved a heavier use of pesticides and in this regard had a more negative environmental impact. Another interesting example in this regard is the comparison between the rice-soybean systems with conventional and minimal tillage. Minimum tillage reduces fuel energy use for soil preparation but it requires a greater use of herbicides than conventional tillage.

The above examples illustrate how trade-offs between different sustainability measures make it difficult if not impossible to design cropping systems that score very high for all measures. A parallel can resemble a physician who cannot cure a patient without producing another disease $e^{3}$. In spite of these challenges it may still be possible to create win-win situations, whereby improvement in one measure of sustainability strengthens another. This is illustrated by the techniques presented in Chapters 4 and 5 of this thesis.

As a last pragmatic essay to support our analysis concerning who is who in the evaluated systems, Table 1 presents and uses the calculated values of what, for farmers, are commonly the three most relevant key indicators: economics, productivity and environment. The primary indicators used to calculate these new KPIs are presented in the Supplementary Information section (item $\mathrm{H}$ ). The mathematical relation between these three macro indicators indicates that Ridges and Cattle is the cropping system that combines most of the accumulated advantages.

The Cumulative Benefit Index (CBI), represents the synthesis of the services which a cropping system is able to provide in terms of immediate social demands: the economic viability of farms (economics), a sufficient and optimized production of food and biomass (land productivity) and environmental preservation (environment). Hence, the CBI can be considered as the most inclusive single sustainability indicator for the cropping systems evaluated.

3 Mark R. Tonelli MD. Annals of Internal Medicine, 1997. http://annals.org/aim/article/710986/utopia 
Evidently, the CBI values only reflect those basic indicators used to generate them and such kind of metric is subjected to criticism (Hayati et al., 2011), can be calculated in many different ways (Reytar et al., 2014) and expanded to a much broader perspective (e.g. in GaitánCremaschi et al., 2017). The proposed CBI index however is the outcome of a robust technical evaluation involving important thematic areas for sustainability, like water and land use, climate change, soil health and pollution, combined with an economic perspective. Overall, apart from the scientific connotation of this approach, I believe that the created index summarizes the kind of information that policymakers, farmers and other stakeholders are interested in, to rapidly appreciate the pro's and con's and help them to take the right decisions.

Table 1. Values for Key Performance Indicators associated with Environment, Land productivity and Economics and the creation of a Cumulative Benefit Index.

\begin{tabular}{|c|c|c|c|c|}
\hline \multirow{3}{*}{ Cropping Systems } & \multicolumn{3}{|c|}{ Key Performance Indicators } & \multirow[b]{2}{*}{$\begin{array}{l}\text { Cumulative Benefit } \\
\text { Index }\end{array}$} \\
\hline & Environment & $\begin{array}{c}\text { Land } \\
\text { productivity }\end{array}$ & Economics & \\
\hline & \multicolumn{4}{|c|}{ - 'benefit-units' ------ } \\
\hline Rice-Fallow & 1.036 & 0.562 & 0.408 & 2.007 \\
\hline Rice-Soybean CT & 0.987 & 0.858 & 1.101 & 2.947 \\
\hline Rice-Soybean MT & 0.916 & 0.796 & 1.095 & 2.807 \\
\hline Ridges and Cattle & 1.040 & 1.522 & 1.782 & 4.343 \\
\hline Ridges and Cover crops & 1.021 & 1.262 & 0.614 & 2.896 \\
\hline
\end{tabular}

* Formula: [Land productivity + Economics + Environment].

The CBI suggests that farmers can achieve substantial gains in sustainability if they develop their cropping systems in a stepwise approach. In traditional rice-based systems, a first step could be the introduction of a model with a higher intensity and crop diversification, like rice-soybean. Indeed, part of the farmers in the lowlands in south Brazil are moving in this direction. As a next step, in the paddies maintained in fallow they could create large ridges, which would allow for cropping systems such as the Ridges and Cattle. Together, this could raise the farm to a substantially higher level of sustainability. Based on my personal experiences obtained during the conductance of the experiments, and with the confirmation of the results expressed in the CBI index, I am not afraid to recommend a lowland farmer to change part of his fallow fields into a ridge-based system with crop-livestock integration. In the next section, the consequences of introducing some of the proposed technologies in the wetlands of south Brazil will be explored, both at farm and regional level. 


\subsection{Extrapolating results}

Facing the farm-oriented results obtained in the experiments conducted in the frame of this thesis research and given the demand for more diversified and sustainable production systems in the lowlands, it is reasonable to establish some projections based on the main outcomes of our studies. Two projections will be described: the first is an exercise simulating the adoption of the ridge-based systems in part of the lowlands. The second consists of an extrapolation of results presented in Chapter 4, where a knife-roller substituted the plough-and-harrow method to prepare the soil after rice harvest. Both simulations include agronomic and environmental results. Since the economics usually is one of the most relevant topics for farmers and stakeholders, the outcomes here presented will also translate the scientific results into the expected economic impact, at farm and regional levels. In this way, a connection is established between science and the real word, as encouraged by Gómez-Baggethun and Martín-López (2015) and Witzke and Noleppa (2016).

\section{Impact of the introduction of ridge-based systems in the lowlands}

In the first projection, it will be simulated that $5 \%$ of the rice fields in RS are turned into a medium-term rotation scheme with the ridge-based systems. In this scheme, three years of rice are rotated with six years of the ridge-based systems (Figure 5). Next to the area withdrawn from the traditional rice, two times this area is withdrawn from fallow, to build the rice-ridge rotation system. In this way, it is assured that the total area covered with rice is not negatively affected due to the introduction of this rotation.

Introducing the ridge-based rotation system in a small part (around 5\%) of the wetland fields might seem a conservative proportion. However, soybean is already used in $18 \%$ of lowland fields not cultivated with rice during the summer, and part of the paddies present a slope high enough ( 2 to $3 \%$ ) to be drained with conventional methods, exempting the construction of a ridge-based system. In this model, 54,600 ha of rice (5\% of the current rice area), and 109,200 ha of the fallow fields will be part of the rice-ridges rotation system.

In this projection, four conditions are fixed: first, the ridges are used during six years, composing a medium-term rotation with three years of irrigated rice (Figure 5). Second, soybean and maize are cultivated in the ridges in four and two seasons, respectively. These proportions correspond to the current interest of farmers for soybean and also meets the need to include maize in rotation, to prevent pest-associated problems in soybean and to increase the 
production of biomass with a high $\mathrm{C}: \mathrm{N}$ ratio. Third, the benefits from the simulated ridge-based systems for soybean and maize yields are set equal to two-thirds of the gains obtained in our long-term experiment. This conservative benefit is proportional to the duration of the ridges in the simulated system (6 years) compared with the duration of the long-term experiment (9 years). And fourth, as the two ridge-based systems evaluated in the long-term experiment (Ridges and Cattle, and Ridges and Cover crops) promoted distinct gains for the crops, the current simulation considers that each of these two cropping systems is used in half of the fields with ridges.

Regional grain yields and total regional grain production for rice, soybean and maize were averaged over a period of five years (2012-2016) and used as a reference. Yield and production for the simulated system is calculated based on these regional averages, applying the four conditions previously described. This simulation assumes that the area of a farm that is part of the rotation is separated in three main fields; one with rice and two with ridges (Figure 5). In the first and second year the farmer will cultivate soybean on the ridges, whereas maize is cultivated in the third year. After these first three years, rice is moved to Field 2, and a ridgesystem is installed on Field 1, following the sequence as presented in Figure 5.
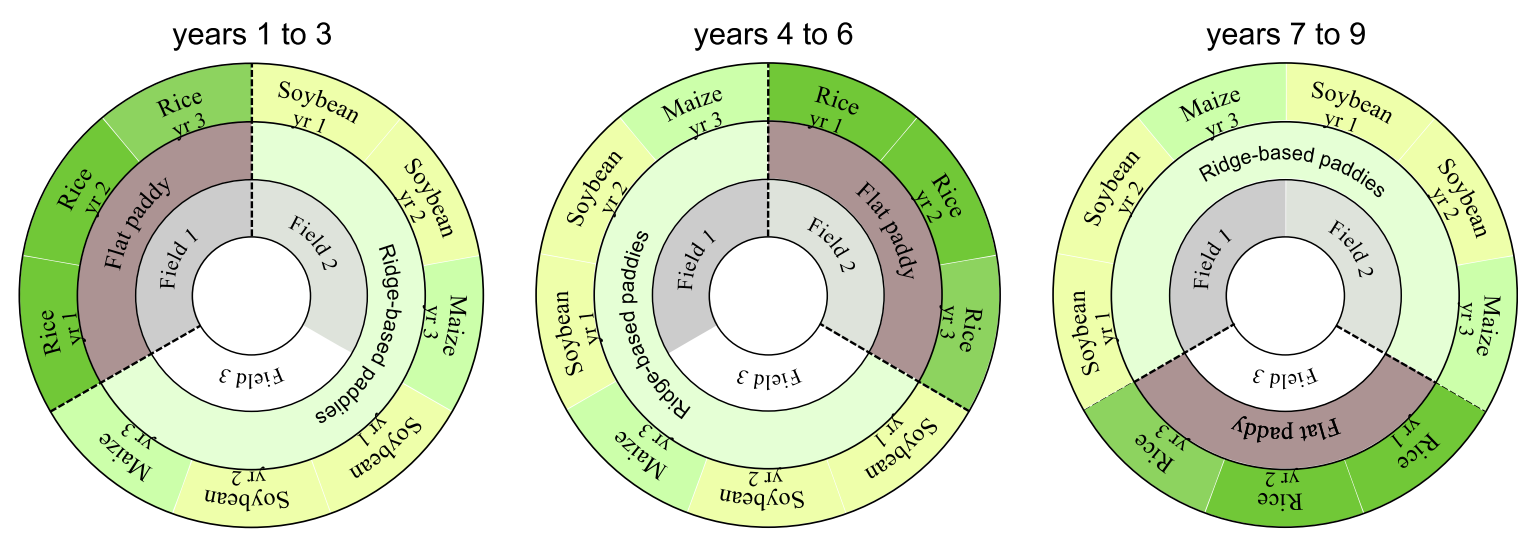

Figure 5. Scheme for a medium-term rotation (irrigated rice-rainfed crops) where a sequence of three-year irrigated rice is followed by 6-year of a ridge-based system, cultivated with soybean (4 seasons) and maize (2 seasons). For each field, a slice represents one year (yr).

In the lowlands of south RS around three million hectares are promptly available for grain-based agriculture. The current utilization rate for grain production corresponds to $49 \%$ of the available land, implying that $51 \%$ remains fallow. With the introduction of the proposed model, land use with grain crops will increase to $53 \%$ (Table 2). This is a relatively small increment, but the proposed value is reasonable: this extension fulfils the demands for new 
fields for grain production, and at the same time it leaves sufficient space for the maintenance of livestock production. This is important, particularly for farmers/ranchers that are currently not prepared to adopt new cropping systems. Also, this apparent short initial insertion of the ridge-based system takes in account that the early-adopter farmers, which are brave enough to immediately install a new system, compound no more than $16 \%$ of the farmer population (Rogers, 2010). This conservative perspective, that distinguishes early adopters, produces an outcome connected with a context of regional changes tangible in the medium term. The results are described in Tables 2 and 3.

The introduction of the ridge-based system increases the use of land for crop production from 1.46 to 1.57 million ha. Grain production is increased with 0.45 million $\mathrm{Mg}$. Compared to the current status, the major impact for an individual crop occurs with maize, with a growth in area slightly larger than $200 \%$, but with gains of around $400 \%$ for grain production and the gross monetary value. The area cultivated with maize is currently declining at regional level, since soybean is preferred by farmers (Figure 4; Chapter 1). Despite the large volume produced, soybean is mostly exported ( $80 \%)$ and rice is characterized by a relatively low aggregated value for the farmer. Maize, on the other hand, is the main component of feedstock, which, converted to animal protein (especially poultry and pig), aggregates around 5 times more value than selling it as unprocessed kernel (IMEA, 2017). This perspective illustrates why maize is so important: it is a crop with large potential to be used on-farm, with the larger capacity to multiply its production value and it also presents one of the best perspectives to contribute to the regional establishment of a robust agribusiness chain. Agribusiness chains associated with animal production have proven to add value to the primary sector, generate jobs and increase prosperity at regional level, as occurs in the north half of RS state (Benetti, 2007; Fochezatto \& Ghinis, 2012).

The inclusion of a ridge-based system would increase the total gross value of grains in the lowlands with 5\%, equivalent to around 340 million $\mathrm{R} \$$ per year. The area on fallow converted to ridges will generate around 3,107 $\mathrm{R} \$ \mathrm{ha}^{-1} \mathrm{yr}^{-1}$, a value equivalent to 4 times the minimum wage in Brazil (averaged 2012-2016). This value does however not represent the net profit obtained by farmers. It is the gross value of production, circulating into the whole regional commerce, which is also positive from a macro-economic perspective (Coronel et al., 2007; Rocha, 2011). At farm-level, for each hectare of fallow modified to receive the ridge-based system, a net profit of $450 \mathrm{R} \$ \mathrm{ha}^{-1} \mathrm{yr}^{-1}$ is expected.

Regarding the use of fields during the winter, the comments will be restricted to the 
ridge-based systems and its potential for livestock production. In this simulation, beef-cattle were used in $50 \%$ of the ridges. Adopting gains in live weight equivalent to 0.66 of the gains obtained in the experiment, an additional production of almost 5.5 million $\mathrm{kg}$ in live weight is expected. This value corresponds to an additional 21.450 million $\mathrm{R} \$$ per year in the whole region. On a hectare-basis, cattle production is equivalent to around $390 \mathrm{R} \$ \mathrm{ha}^{-1}$ per year, and presents a benefit of being produced and sold during winter and spring, off season for the cashcrops, which are primarily sold in autumn.

Table 2. Area, production, gross value and impact for the current status of cultivation and simulating the implantation of a rotation (irrigated rice: rainfed crops, proportion 1:2) on 5\% of rice fields in RS, where a sequence of three-year irrigated rice is followed by 6-year of a ridgebased system, with soybean (in 4 seasons) and maize (in 2 seasons). Values presented are yearly averages.

\begin{tabular}{|c|c|c|c|c|}
\hline & Rice & Soybean & Maize & Totals \\
\hline \multicolumn{5}{|c|}{ Current status (2012-2016) for lowland production in RS } \\
\hline Area (ha) & $1,091,764$ & 350,000 & 17,000 & $1,458,764$ \\
\hline Production $(\mathrm{Mg})$ & $8,041,268$ & 880,950 & 58,871 & $8,981,089$ \\
\hline Gross value $(\mathrm{R} \$)$ & $5,785,266,139$ & $982,811,606$ & $27,407,912$ & $6,795,485,657$ \\
\hline \multicolumn{5}{|c|}{ Simulation: production in the ridge-based systems } \\
\hline Area (ha) & & 72,784 & 36,392 & 109,176 \\
\hline Production $(\mathrm{Mg})$ & & 201,539 & 245,755 & $452,770^{1}$ \\
\hline Gross value $(\mathrm{R} \$)$ & & $224,842,234$ & $114,413,485$ & $339,277,174^{1}$ \\
\hline \multicolumn{5}{|c|}{ Results: current status embedding the new rice-ridge rotation } \\
\hline Area (ha) & $1,091,764$ & 422,784 & 53,392 & $1,567,940$ \\
\hline Production (Mg) & $8,041,268$ & $1,082,489$ & 304,606 & $9,432,950$ \\
\hline Gross value (R\$) & $5,785,266,139$ & $1,207,653,840$ & $141,821,397$ & $7,134,762,830$ \\
\hline \multicolumn{3}{|c|}{ Social impact: food production } & Current status & $\begin{array}{l}\text { Embedding the } \\
\text { simulated data }\end{array}$ \\
\hline \multicolumn{3}{|c|}{ Energy produced (for human consumption, GJ) } & $105,739,551$ & $113,135,635$ \\
\hline \multicolumn{3}{|c|}{ Persons feed per year (base $8.7 \mathrm{MJ}$ day $^{-1}$ ) } & $33,298,552$ & $35,627,660$ \\
\hline \multicolumn{3}{|l|}{ Difference } & - & $2,329,109$ \\
\hline \multicolumn{5}{|c|}{ Environmental impact: pesticides } \\
\hline \multicolumn{3}{|c|}{ Pesticides applied in lowlands $(\mathrm{kg})^{2}$} & $3,878,438$ & $4,208,507$ \\
\hline \multicolumn{3}{|l|}{ Average $\left(\mathrm{kg} \mathrm{ha}^{-1}\right)$} & 2.343 & 2.505 \\
\hline \multicolumn{3}{|l|}{ Difference } & - & 0.161 \\
\hline \multicolumn{3}{|c|}{ Amounts in the area with rice-ridges $\left(\mathrm{kg} \mathrm{ha}^{-1}\right)$} & 0.855 & 2.870 \\
\hline
\end{tabular}


In terms of social and environmental impacts, our calculation points out that the additional annual food produced by inserting a ridge-based system in part of the fallow fields would be sufficient to nourish around 2.33 million persons, on an energy basis. One drawback from intensifying grain production, however, is that the use of pesticides in the lowlands would increase from the current 3.9 million to 4.2 million $\mathrm{kg}$ of active ingredient per year. Considering all the cultivated area, this increase represents an annual addition of $0.161 \mathrm{~kg} \mathrm{ha}^{-1}$ of pesticides. In the fields under rotation the intensification on pesticide use is relatively high: rates would leap from the current $0.855 \mathrm{~kg} \mathrm{ha}^{-1} \mathrm{yr}^{-1}$ (rice-fallow) to $2.87 \mathrm{~kg} \mathrm{ha}^{-1} \mathrm{yr}^{-1}$ (ridge-based systems). To offset or reduce such larger use of pesticides in these areas, some measures could be taken like focussing on the use of products with a low environmental impact (e.g. bio-based pesticides), training farmers to improve their application techniques, and using non-chemical pest management methods, such as: good-quality seeds, finishing cover crops mechanically, crop cultivars tolerant to pests, or a seeder provided with skis to reduce weed seed germination, as presented in Chapter 5.

Beside the outcomes for production and pesticide use, an important point to consider are the effects associated with biomass production and the carbon balance. On average, the ridge-based systems effectively sequestered carbon into the soil as organic matter, at a rate between $16 \%$ and $20 \%$ of the carbon contained in the biomass. In contrast, the rice-based systems sequestered only between 1 to $12 \%$ (Chapter 2). For this simulation, it is assumed that in the current system $6.3 \%$ of carbon in biomass is incorporated as organic matter, in contrast to $16 \%$ for the ridge-based systems, which corresponds to the smallest value found for the ridges in the long-term experiment.

With these data, a projection about carbon balance and the expected monetary returns from selling carbon credits can be calculated. A carbon credit is a financial unit of measurement that represents the removal of one ton $(1 \mathrm{Mg})$ of carbon dioxide equivalent $\left(\mathrm{tCO}_{2} \mathrm{e}\right)$ from the atmosphere (Nicolletti \& Lefèvre, 2016). In this perspective, Conservation Agriculture systems accumulating carbon into the soil would receive extra revenues resulting from their benefits for the environment. Prices for carbon credits are variable worldwide. This simulation used the values used in Europe, one of the more referred markets at international level. Values were quoted at 6.68 Euro per $\mathrm{Mg}$ of $\mathrm{CO}_{2}$-e, corresponding to the average prices between 2012 and 2016. Table 3 summarizes these results.

The rice-based cropping systems incorporated annually around $0.13 \mathrm{Mg} \mathrm{ha}^{-1}$ of carbon into the soil, whilst the ridge-based system incorporated at least $0.42 \mathrm{Mg} \mathrm{C}^{-1}$ per year. A 
detailed analysis of cause-effects on carbon balance is out of the scope of this discussion. It is however worth to mention that the rice-based systems hardly changed SOM in the course of the 9-yr experiment (Figure 4 in Chapter 2). Most of carbon which would be sequestered as organic matter in rice-based systems was probably lost to the atmosphere. In contrast, the ridge-based systems accumulated carbon into the soil. In the area submitted to rice-ridges rotation, a total of $53,221 \mathrm{Mg}$ of carbon would be sequestered into the soil, from which $87 \%$ is provided by the ridge-based systems. The ridges would mitigate a total of 143.7 thousand $\mathrm{Mg} \mathrm{CO}$-e, an equivalent to $1,552 \mathrm{~kg} \mathrm{CO}_{2}$-e ha-1. In this simulation, one hectare of ridges would be enough to compensate greenhouse emissions of approximately 460 liters of diesel consumed by a modern tractor, which cover the operational needs for 1.25 ha of a rice-ridges system. More striking numbers come when these results are presented in an urban perspective: $1,552 \mathrm{~kg} \mathrm{CO}_{2}$-e (mitigated by 1 ha of the ridge-based systems) corresponds to the emissions from a regular diesel vehicle running for $10,500 \mathrm{~km}$, according to the current European specifications (Zachariadis, 2013).

Table 3. Carbon sequestered into soil organic matter (SOM) in the current status of rice cultivation and from the implantation of a med-term rotation (irrigated rice: rainfed crops, proportion 1:2) where a sequence of three-year irrigated rice is followed by 6-year of a ridgebased system, cultivated with soybean (4 seasons) and maize ( 2 seasons). Values presented are yearly averages.

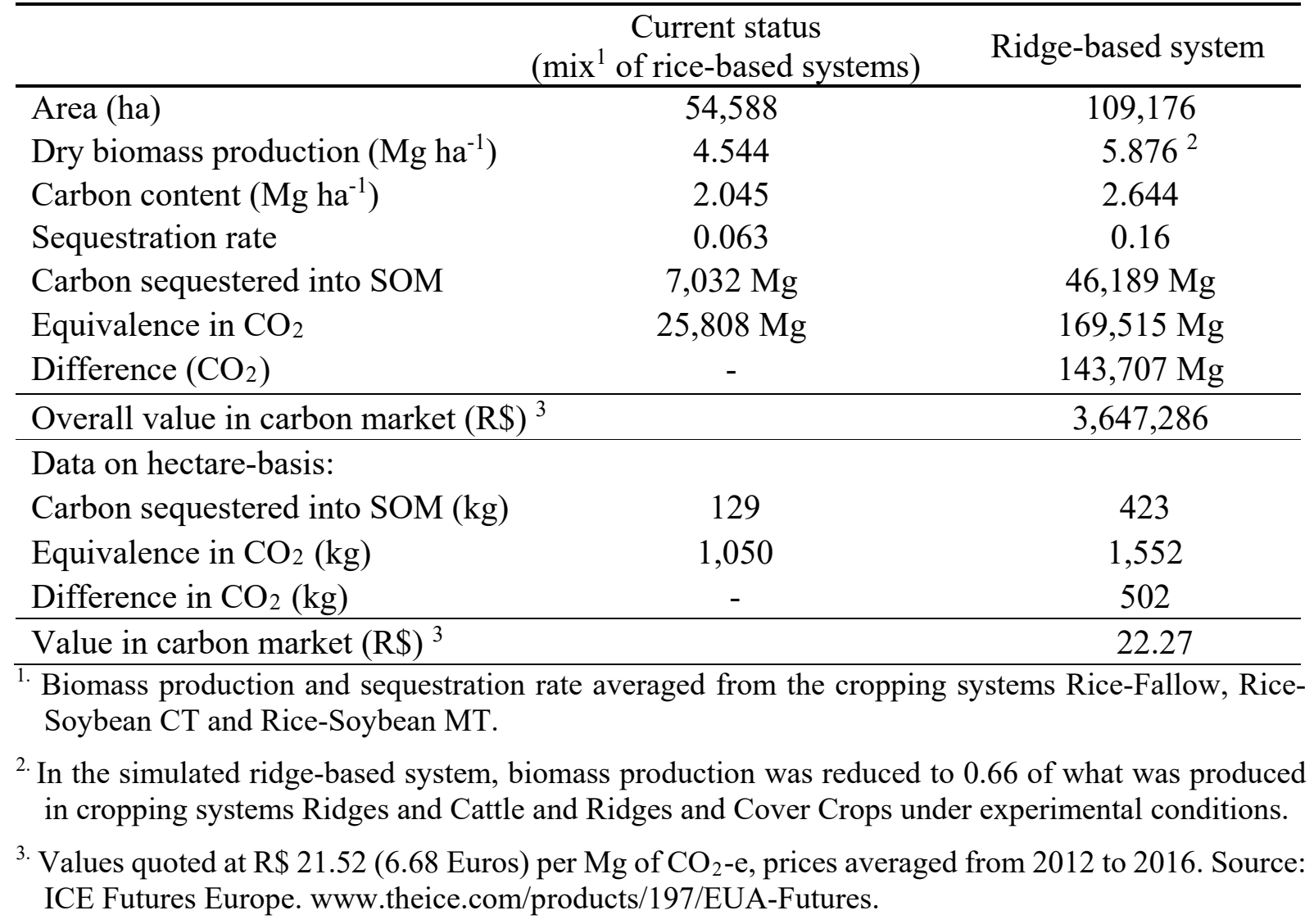


Payment for carbon mitigation resulting from good practices in agriculture is still in an early stage of development in most South American countries. At international level however, the valuation of carbon credits is already a reality, with prices negotiated comparable to other commodities on stock markets. According to the simulated data, a total of 3.6 million R\$ (around 1.1 million Euro) would be potentially earned per year, as a result of adopting the ridge-based system in a part of the fallow fields. On a hectare-basis the added value attains just 22.27 R \$ per year ${ }^{-1}$, which perhaps is not enough to instigate a small farmer to change his cropping system. The utilization of these resources in a collective manner would possibly make it worth the effort (e.g. financing training or similar activities in a cooperative), as previously reported by Nicolletti and Lefèvre (2016) for agro-forestry systems in Brazil.

\section{Using the knife-roller method as a substitute for conventional plough-based soil preparation}

In the rice-based systems of south Brazil, the harvest of rice is a fully mechanized process. As argued in Chapter 4, harvest machinery promotes intense soil disturbance, to which soil adjustments are required to seed the next summer crop or to allow winter pastures to establish and grow. Soil preparation using plough, harrow and levelling are energy-expensive and should preferably be conducted when the soil is dry. In this study, an alternative method for soil preparation based on a heavy knife roller was tested. This unconventional technique was shown to be a convenient solution to substitute plough and harrow in paddy fields.

An extrapolation of the results obtained with the roller-based method requires some precautionary assumptions, since the knife-roller requires a specific soil condition: a flooded field. The problem is that not on all farms the paddies can be maintained with a layer of water after rice harvest, because of logistic issues and costs. Hence, this projection starts by fixing an area which could -at least theoretically- be easily maintained flooded after rice harvest. Data about the soil slope from the ecological zones of rice production were used as a starting point (Table 1, in Chapter 1). From the six zones, three (Internal Coast, External Coast and South Zone; map in Chapter 1) present a relatively large proportion of entirely flat soils (31\%). Hence, the domain for this simulation will be limited to these three regions, in which approximately 473,000 ha of rice is cultivated. Also in this simulation it is assumed that the introduction of this technology will initially only be undertaken by the 16\% Innovators and Early Adopters (Rogers, 2010). For the three selected regions, this percentage corresponds to around 560 adopters, with on average 156 ha of rice each (data calculated from Table 2; Chapter 1). As in some instances water is severely limited, this simulation further considers that only one third 
of the rice fields in each farm can be maintained flooded after harvest. This implies that the knife-roller will substitute plough and harrow operations in approximately 29,000 ha, which corresponds to $6 \%$ of the rice acreage annually cultivated in these three regions considered.

Data presented in Table 4 includes all soil operations conducted with the conventional and with the alternative knife-roller method described in Chapter 4. The only exception is that in both situations the use of a narrow trencher after soybean seeding was not included. The simulation herein is not limited to a rice-soybean rotation, but for any crop or pasture following irrigated rice.

Table 4. Time, diesel and GHG emissions associated with the conventional and the knife-roller methods for soil preparation after rice harvest in lowland paddies.

\begin{tabular}{|c|c|c|c|}
\hline & \multicolumn{2}{|c|}{ Soil preparation method } & \multirow{2}{*}{ Difference } \\
\hline & Plough and harrow & Knife-roller & \\
\hline \multicolumn{4}{|l|}{ Measured data, hectare-basis } \\
\hline Hours of work $\left(\mathrm{h} \mathrm{ha}^{-1}\right)$ & 8.55 & 4.35 & $4.2 \mathrm{~h}$ \\
\hline Diesel consumed $\left(\mathrm{L} \mathrm{ha}^{-1}\right)$ & 81.8 & 28.2 & $53.6 \mathrm{~L}$ \\
\hline GHG emitted $\left(\mathrm{Mg} \mathrm{CO}_{2}-\mathrm{e} \mathrm{ha}^{-1}\right)$ & 0.276 & 0.095 & $0.181 \mathrm{Mg}$ \\
\hline \multicolumn{4}{|c|}{ Simulated data at regional level: 28,883 ha } \\
\hline Hours of work (h) & 246,950 & 125,641 & 121,309 \\
\hline Diesel consumed $(\mathrm{L})$ & $2,362,629$ & 814,501 & $1,548,128$ \\
\hline GHG emitted $\left(\mathrm{Mg} \mathrm{CO}_{2}-\mathrm{e}\right)$ & 7,972 & 2,744 & 5,228 \\
\hline \multicolumn{4}{|c|}{ Impact in a typical regional farm (1/3 or rice area managed with knife-roller) } \\
\hline Hours of work (h) & 445 & 226 & 219 \\
\hline Diesel consumed $(\mathrm{L})$ & 4,254 & 1,466 & 2,788 \\
\hline GHG emitted ( $\left.\mathrm{Mg} \mathrm{CO}_{2}-\mathrm{e}\right)$ & 14.35 & 4.94 & 9.41 \\
\hline Economic value (work, $\mathrm{R} \$)^{1}$ & 3,667 & 1,862 & 1,805 \\
\hline Economic value (diesel, R\$) ${ }^{1}$ & 10,763 & 3,709 & 7,054 \\
\hline \multicolumn{3}{|c|}{ Carbon credits: mitigation of $9.41 \mathrm{Mg} \mathrm{CO} 2-\mathrm{e}^{2}(\mathrm{R} \$)$} & 202 \\
\hline \multicolumn{3}{|c|}{ Total on-farm economic benefit ( $\mathrm{R} \$$ ) } & 9,061 \\
\hline
\end{tabular}

1. Economic value for work assuming a rural worker earns monthly $2 \mathrm{x}$ the regional minimum wage, with 54 hours work per week.

2. Carbon credits quoted at $\mathrm{R} \$ 21.52$ (6.68 Euros) per $\mathrm{Mg}$ of $\mathrm{CO}_{2}$-e. Source: ICE Futures Europe. www.theice.com/products/197/EUA-Futures. All prices averaged from 2012 to 2016.

Under experimental conditions, the knife-roller method reduced the time required to prepare the soil with $49 \%$, diesel consumption with $65 \%$ and GHG emission with $66 \%$. Extrapolating these values to a regional projected scope, the savings on fuels could be as large as 1.54 million litres per year, and a mitigation of 5.2 thousand $\mathrm{Mg}$ of carbon-dioxide equivalent would be attained. 
Based on the last census conducted in the RS, a typical regional farm considered in this simulation cultivates 156 ha of rice (IRGA, 2006). If a farm adopts a similar method for soil management as proposed (roller in one third of the rice area), the time required to prepare the soil after rice harvest would be reduced with more than 200 hours per year, compared to using the conventional method. The benefits arising from the use of this technology are numerous. Besides monetary savings, a lower demand for labour can represent less stress to find temporary rural workers (sometimes scarcely available), and a chance to dedicate more time to other activities. The most striking result however is related to the large reduction in fuel consumption. On an average-sized farm, the knife-roller can potentially save almost 2.8 thousand litres of diesel per year.

Expressed in monetary value, using a knife-roller as substitute for plough and harrow represents considerable savings. The larger gains are associated with the lower consumption of diesel: a typical farm, in this case, would save more than 7 thousand Brazilian Reals (around 2,190 Euros) per year. Additionally, in a hypothetical scenario where carbon credits would be marketable, the mitigation of $\mathrm{CO}_{2}$ represented by savings of diesel would annually attain to $\mathrm{R} \$$ 200 per farm. Such a low amount is perhaps hardly sufficient to stimulate an individual farmer, but, by joining efforts like in a Cooperative, it could be worth it. Considering the mitigation at regional level, these carbon credits correspond to annual earnings of 112.5 thousand Brazilian reals (around $€ 35,000$ ). Such an amount could be invested in collective actions, like the appointment of a consultant.

\subsection{Concluding Remarks}

In an overall perspective, the study presented in this thesis consists of three main parts. The introduction of lowland agriculture in south Brazil, the evaluation of five cropping systems, and the assessment of two specific technologies.

Many people firmly believe that the wetland farming systems should, and can be improved. The challenge however is to know what has to be done. The larger part of the research presented in this thesis consisted of a comprehensive investigation of distinct cropping systems for lowlands. This study identified strengths and weakness of current and of innovative systems, and evaluated technologies which can contribute to improve the sustainability of lowland agriculture. Stepwise improvements for rice-based systems have been constantly offered, either by research institutions or by commercial companies, but hardly ever you will find large-scale, in-depth comparisons between entire systems. 
A comparison like this is helpful and needed to understand the cropping systems in the lowlands and to propose effective improvements in these agricultural systems. In this thesis, five systems were arranged in a way that carried a subliminal message: the evolution of lowland systems in south Brazil could follow the same line as was followed in this study. It naturally starts with a simple rice monocrop, the predominant system in the RS state, then evolves to rice-soybean rotations, and culminates with the adoption of a more complex model represented by the ridge-based systems.

Several farms already progressed from the first step -monocrop rice- into the second step, a rice-soybean rotation. However, it seems that the use of fields with just summer crops, and a low crop diversity restricted to rice and soybean, is a kind of accepted limit, as it would be the top of the evolution for lowland cropping systems ${ }^{4}$. The explanation for this is the technical convenience of this rotational model (rice-soybean) for farmers, as well as the large monetary earnings received by suppliers and grain merchandizers, who feed themselves through this heavily input-based system. The situation, for the largest part of grain-farming in south Brazil, is that these actors have ruled (or, at least, greatly influenced) the agriculture in the lowlands. Apart from this inconvenient truth, what is proposed in this thesis is not incompatible with the current status of rice monocropping or rice-soybean cultivation. However, by identifying the key points to make these systems more sustainable, as well as offering alternative technologies for the lowland cropping systems, it is possible to make a better agriculture in these fields. Obviously, these ideas and hypotheses are not just a dream, but are accompanied by meaningful and robust results in support of such a development.

Thinking about the future, the evolution of cropping systems in the lowlands will perhaps not exactly follow the succession that was projected in the long-term experiment. It might even be that the ridge-based systems will not be part of the near future. However, from an optimistic view, it is reasonable to assume that the knowledge and the technologies raised through this work will be empowered by farmers at some point in time. Particularly for the ridge-based concept, since the ridges are relatively simple to construct and the system does conveniently fit to the large area of fields maintained fallow. The results obtained do show that Ridges and Cattle represents a better option than Ridges and Cover crops.

\footnotetext{
${ }^{4}$ Some examples in this regard are expressed in the calls from the media reports in the most common farmer-oriented magazines in Brazil like: "Soybean, the salvation of rice fields", "The perfect combination"; "Rice and Soybean, the gaucho's marriage" and "(Soybean) on lowland". Respective links are provided in the Supplementary Information section, item G.
} 
It would be very audacious to assume that the systems planned and evaluated would be perfect. They are far from that. However, identifying and knowing some of the limitations of these cropping systems was the basis for the final part of this thesis, where some technologies were tested. The knife-roller, an avant-garde method to prepare lowlands soils, can help to improve sustainability in the rice-based systems. The $s k i$, adapted to no-tillage seeders, brings the improvements at a higher level, particular for innovative models like the ridge-based systems. Although the two solutions presented are technologically simple, both carry an expressive robustness and practicability, adequately adjusted to the complex agriculture of today. I cannot say that I'm not proud of having contributed to the development of these technologies, but still the important and hard work of diffusion to the farming community has yet to come.

\subsection{References}

Alary V, CORBEels M, AfFHOlder F et al. (2016) Economic assessment of conservation agriculture options in mixed crop-livestock systems in Brazil using farm modelling. Agricultural Systems 144, 33-45.

AltMAN EI (1968) Financial ratios, discriminant analysis and the prediction of corporate bankruptcy. The Journal of Finance 23, 589-609.

Balbinot Junior AA, Moraes Ad, Veiga Md, Pelissari A \& Dieckow J (2009) Integração lavoura-pecuária: intensificação de uso de áreas agrícolas. Ciencia Rural 39, 1925-1933.

BALdi G \& PARUelo JM (2008) Land-use and land cover dynamics in South American temperate grasslands. Ecology and Society 13.

BARATA TS \& TOLEDO R (2015) Mensuração do custo de produção de arroz irrigado no Rio Grande do Sul safra 2014/2015. (Assessment of production costs of irrigated rice in RS state, Brazil, in 2014/2015 cropping season). 19p. Ministério da Agricultura, Pecuária e Abastecimento, Brasília, Brazil.

BenetTi MD (2007) Perspectivas de transformações estruturais na economia da Metade Sul do Estado. Indicadores Econômicos FEE 34, 129-142.

BIJAY S, SHAN YH, JoHnSON-BEEBOUt SE, YADVINDER S \& BURESH RJ (2008) Crop residue management for lowland rice-based cropping systems in Asia. In: Advances in Agronomy, Vol. 98, 117-199. Academic Press.

Bockstaller C, Guichard L, Keichinger O, Girardin P, Galan M-B \& Gaillard G (2009) Comparison of methods to assess the sustainability of agricultural systems: a review. In: Sustainable Agriculture. (eds E Lichtfouse, M Navarrete, P Debaeke, S Véronique \& C Alberola), 769-784. Springer Netherlands, Dordrecht.

BoeHMEL C, LEWANDOWSKI I \& ClAUPEIN W (2008) Comparing annual and perennial energy cropping systems with different management intensities. Agricultural Systems 96, 224236.

Boeni M, ANGHinoni I, Junior SAG \& FiLho BDO (2010) Evolução da fertilidade dos solos 
cultivados com arroz irrigado no Rio Grande do Sul. In: Boletim Técnico, 40. IRGA/Estação Experimental, Cachoeirinha, Brazil.

BUCHER S (2017) Environmental performance as one of the indicators of sustainable development in Asia. Journal of Environmental Biology 38, 67-74.

Clarke N, Bizimana JC, Dile Y et al. (2017) Evaluation of new farming technologies in Ethiopia using the Integrated Decision Support System (IDSS). Agricultural Water Management 180, 267-279.

CONAB (2016) Evolução dos custos de produção de arroz no Brasil. In: Compêndio de estudos CONAB., Vol. 4, 29. CONAB - Companhia Nacional de Abastecimento, Brasília, Brazil.

Coronel DA, Alves FD \& Silva MAE (2007) Notas sobre o processo de desenvolvimento da metade sul e norte do estado do Rio Grande do Sul: uma abordagem comparativa. Perspectiva Econômica 3, 27-43.

CoutTs C \& HAHN M (2015) Green infrastructure, ecosystem services, and human health. International Journal of Environmental Research and Public Health 12, 9768-9798.

DAG HAMMARSKJÖLd FoundATION (2015) The Power of Numbers - Beyond economic growth and global statistics. In: Dag Hammarskjöld Foundation/UNDP Seminar Series. After 2015 - The road towards the next global development agenda, 4. Dag Hammarskjöld Foundation, Uppsala.

DAILy G \& ElLISON K (2003) The New Economy of Nature: The Quest to Make Conservation Profitable. Island Press.

DE FREITAS PL \& LANDERS JN (2014) The Transformation of Agriculture in Brazil Through Development and Adoption of Zero Tillage Conservation Agriculture. International Soil and Water Conservation Research 2, 35-46.

De Luca Ai, Iofrida N, Leskinen P, Stillitano T, Falcone G, Strano A \& Gulisano G (2017) Life cycle tools combined with multi-criteria and participatory methods for agricultural sustainability: Insights from a systematic and critical review. Science of The Total Environment 595, 352-370.

De Moraes A, Carvalho PCDF, Anghinoni I, Lustosa SBC, Costa SEVGDA \& KunRath TR (2014) Integrated crop-livestock systems in the Brazilian subtropics. European Journal of Agronomy 57, 4-9.

De Olde EM, Oudshoorn FW, Sørensen CAG, BokKers EAM \& DE Boer IJM (2016) Assessing sustainability at farm-level: Lessons learned from a comparison of tools in practice. Ecological Indicators 66, 391-404.

DO AmARAL LG \& Righes AA (2005) Automatic structures for water control in channels on irrigated rice crops. Engenharia Agricola 25, 272-281.

Durno J, Moeliono I, Prasertcharoensuk R \& Network SASA (1992) Resource Book on Sustainable Agriculture for the Lowlands. Southeast Asia Sustainable Agriculture Network.

FAGERIA NK (2012) Role of Soil Organic Matter in Maintaining Sustainability of Cropping Systems. Communications in Soil Science and Plant Analysis 43, 2063-2113.

FERREIRA FDF, NEUMANN PS \& HOFFMANN R (2014) Análise da matriz energética e econômica das culturas de arroz, soja e trigo em sistemas de produção tecnificados no Rio Grande 
do Sul. Ciencia Rural 44, 380-385.

Finn D, Kopittke PM, DenNis PG \& Dalal RC (2017) Microbial energy and matter transformation in agricultural soils. Soil Biology and Biochemistry 111, 176-192.

FochEZATTO A \& GHINIS CP (2012) Estrutura produtiva agropecuária e desempenho econômico regional: o caso do Rio Grande do Sul, 1996-2008. Revista de Economia e Sociologia Rural 50, 743-762.

Foley JA, RAMANKUTTY N, BRAUMAN KA et al. (2011) Solutions for a cultivated planet. Nature 478, 337-342.

FRESCO LO (1995) Agro-ecological knowledge at different scales. In: Eco-regional approaches for sustainable land use and food production: Proceedings of a symposium on ecoregional approaches in agricultural research, 12-16 December 1994, ISNAR, The Hague. (eds J Bouma, A Kuyvenhoven, BaM Bouman, JC Luyten \& HG Zandstra), 133141. Springer Netherlands, Dordrecht.

GAItÁN-CREMASCHi D, MEuwissen MPM \& OUdE AGJM (2017) Total factor productivity: A framework for measuring agri-food supply chain performance towards sustainability. Applied Economic Perspectives and Policy 39, 259-285.

Garrigues E, Corson MS, Angers DA, van Der Werf HMG \& Walter C (2012) Soil quality in Life Cycle Assessment: Towards development of an indicator. Ecological Indicators 18, 434-442.

GARRITY DP, GINES HC \& No (1990) The development of rice-corn rotations in tropical lowland environments: a systems research approach. In: Extension Bulletin - ASPAC, Food \& Fertilizer Technology Center, Vol. 316, 24p. IRRI, Manila, Philippines.

George T, LAdHA JK, Buresh RJ \& GARrity DP (1992) Managing native and legume-fixed nitrogen in lowland rice-based cropping systems. In: Biological Nitrogen Fixation for Sustainable Agriculture: Extended versions of papers presented in the Symposium, Role of Biological Nitrogen Fixation in Sustainable Agriculture at the 13th Congress of Soil Science, Kyoto, Japan, 1990, 69-91. Springer Netherlands, Dordrecht.

GHIMire R, AdHIKARI KR, CHEN ZS, SHAH SC \& DAHAL KR (2012) Soil organic carbon sequestration as affected by tillage, crop residue, and nitrogen application in rice-wheat rotation system. Paddy and Water Environment 10, 95-102.

GILL BS \& JALOTA SK (1996) Evaporation from soil in relation to residue rate, mixing depth, soil texture and evaporativity. Soil Technology 8, 293-301.

Giller KE, Witter E, Corbeels M \& Tittonell P (2009) Conservation agriculture and smallholder farming in Africa: The heretics' view. Field Crops Research 114, 23-34.

GIORDANO CPDS (2014) Resposta da soja a períodos de inundação em um gleissolo. Master, Universidade Federal do Rio Grande do Sul, Porto Alegre, Brazil.

Gómez-BAgGethun E \& MARTín-LóPez B (2015) Ecological economics perspectives on ecosystem services valuation. In: Handbook of Ecological Economics. (eds J MartínezAlier \& R Muradian), 1 edn, 260-282. Edward Elgar Publishing Limited, Cheltenham (UK) and Northampton (USA).

Goulart ICGR, Borba TCO, Menezes VG \& Merotto A (2014) Distribution of weedy red rice (Oryza sativa) resistant to imidazolinone herbicides and its relationship to rice cultivars and wild Oryza species. Weed Science 62, 280-293. 
Hammond J, Fraval S, van Etten J et al. (2017) The Rural Household Multi-Indicator Survey (RHoMIS) for rapid characterisation of households to inform climate smart agriculture interventions: Description and applications in East Africa and Central America. Agricultural Systems 151, 225-233.

HAYATI D, RANJBAR Z \& KARAMI E (2011) Measuring Agricultural Sustainability. In: Biodiversity, Biofuels, Agroforestry and Conservation Agriculture, Vol. 5. (ed E Lichtfouse), 73-100. Springer Netherlands, Dordrecht.

Himmelstein J, ARES A \& VAN Houweling E (2016) Sustainable intensification: a multifaceted, systemic approach to international development. Journal of the Science of Food and Agriculture 96, 4833-4839.

IAPAR (2002) Máquinas bem adaptadas: plantio direto de qualidade (Machines well adapted: no-tillage with quality). In: Editorial. (ed IaD Paraná), 6. Iapar, Londrina, PR, Brasil.

ICMBio (2014) Relatório anual de rotas e áreas de concentração de aves migratórias no Brasil. (eds ACD Oliveira, AEA Barbosa, AEBaD Souza et al.), 1 edn, 88. CEMAVE/ICMBio, Cabedelo, Brazil.

IMEA (2017) Boletim Semanal do Milho. In: Valor agregado (aggregated value for maize), Vol. 443, 12. Instituto Mato-grossense de Economia Agropecuaria, Cuiabá, Brazil.

IRGA (2006) Censo da lavoura de arroz irrigado do Rio Grande do Sul - safra 2004/05.

IRGA (2017) Services and Informations - Cropping Seasons. Available at: http://www.irga.rs.gov.br/conteudo/4215/safras (accessed 05 Jan 2017).

Jane Dillon E, Hennessy T, Buckley C, Donnellan T, Hanrahan K, Moran B \& Ryan M (2016) Measuring progress in agricultural sustainability to support policy-making. International Journal of Agricultural Sustainability 14, 31-44.

Johannes A, Matter A, Schulin R, Weisskopf P, Baveye PC \& Boivin P (2017) Optimal organic carbon values for soil structure quality of arable soils. Does clay content matter? Geoderma 302, 14-21.

KHOSA MK, SIDHU BS \& BENBI DK (2011) Methane emission from rice fields in relation to management of irrigation water. J Environ Biol 32, 169-172.

KIRK GJD \& OLK DC (2000) Carbon and nitrogen dynamics in flooded soils. Proceedings of the workshop on Carbon and Nitrogen Dynamics in Flooded Soils, 19-22 April 1999. IRRI - International Rice Research Institute, Los Baños, Philippines.

Lapola DM, Martinelli LA, Peres CA et al. (2014) Pervasive transition of the Brazilian land-use system. Nature Clim. Change 4, 27-35.

LENG RA (2008) Decline in available world resources; implications for livestock production systems in Asia. Livestock Research for Rural Development 20, Article \#8.

LIN H-C \& HÜLSBERGEN K-J (2017) A new method for analyzing agricultural land-use efficiency, and its application in organic and conventional farming systems in southern Germany. European Journal of Agronomy 83, 15-27.

Marchesan E, Zanella R, Avila LAd, CAMargo ER, Machado SLdO \& Macedo VRM (2007) Rice herbicide monitoring in two Brazilian rivers during the rice growing season. Scientia Agricola 64, 131-137.

MARTin G, Moraine M, RYschawy J et al. (2016) Crop-livestock integration beyond the farm level: a review. Agronomy for Sustainable Development 36, 53. 
MARTINS AP, DENARDIN LGDO, BORIN JBM et al. (2017) Short-term Impacts on Soil-quality Assessment in Alternative Land Uses of Traditional Paddy Fields in Southern Brazil. Land Degradation and Development 28, 534-542.

MAtUlis BS (2014) The economic valuation of nature: A question of justice? Ecological Economics 104, 155-157.

Meena BP, Shirale AO, Dotaniya ML, Jha P, Meena AL, Biswas AK \& Patra AK (2016) Conservation agriculture: A new paradigm for improving input use efficiency and crop productivity. In: Conservation Agriculture: An Approach to Combat Climate Change in Indian Himalaya, 39-69.

NACHBIN L (1981) Introduction to functional analysis, Banach spaces, and differential calculus. M. Dekker.

Nicolletti MX \& LefĖVRe GB (2016) Precificação de carbono no Brasil: perspectivas e aprendizados a partir de uma simulação de mercado cup-and-trade. Cadernos Adenauer 17, 145-169.

ONO K, MANO M, HAN GH et al. (2015) Environmental controls on fallow carbon dioxide flux in a single-crop rice paddy, Japan. Land Degradation \& Development 26, 331-339.

Penot J-P (2016) Analysis - From concepts to applications, (eds. S Axler, V Capasso, C Casacuberta et al.). Springer Nature, Paris.

Peral J, Maté A \& Marco M (2017) Application of Data Mining techniques to identify relevant Key Performance Indicators. Computer Standards and Interfaces 50, 55-64.

Porto MF \& SOARES WL (2012) Modelo de desenvolvimento, agrotóxicos e saúde: um panorama da realidade agrícola brasileira e propostas para uma agenda de pesquisa inovadora. Revista Brasileira de Saúde Ocupacional 37, 17-31.

Refatti JP, Avila LAd, Noldin JA, PACheCo I \& Pestana RR (2017) Leaching and residual activity of imidazolinone herbicides in lowland soils. Ciencia Rural 47.

Reytar K, Hanson C \& Henninger N (2014) Working Paper: Indicators of sustainable agriculture: a scoping analysis. In: Creating a Sustainable Food Future, 20. World Resources Institute.

RILEY J (2001) Indicator quality for assessment of impact of multidisciplinary systems. Agriculture, Ecosystems \& Environment 87, 121-128.

Rocha JM (2011) As Raízes da Crise da Metade Sul. Estudo da formação econômica do Rio Grande do Sul, (ed. Unipampa), 1 edn. Fundação Universidade Federal do Pampa, Jaguarão, RS, Brazil.

Rogers EM (2010) Diffusion of innovations, Fourth edn. The Free Press, New York.

Rosolem CA, Li Y \& GARCIA RA (2016) Soil carbon as affected by cover crops under no-till under tropical climate. Soil Use and Management 32, 495-503.

SAdRAs VO, CASSMAN KGG, Grassini P et al. (2015) Yield gap analysis of field crops Methods and case studies. In: FAO Water Reports No. 41, Vol. 1, 82. FAO, Rome, Italy.

SAPKota TB, MAZzoncini M, BARberi P, ANTICHI D \& Silvestri N (2012) Fifteen years of no till increase soil organic matter, microbial biomass and arthropod diversity in cover crop-based arable cropping systems. Agronomy for Sustainable Development 32, 853863. 
Seufert V, RAMANKutTy N \& Foley JA (2012) Comparing the yields of organic and conventional agriculture. Nature 485, 229-232.

SHARMA A, GIRI SK, KARTHA KPR \& SANGWAN RS (2017) Value-additive utilization of agrobiomass: preparation of cellulose triacetate directly from rice straw as well as other cellulosic materials. RSC Advances 7, 12745-12752.

Silva DROd, Avila LAd, Agostinetto D, Dal Magro T, Oliveira Ed, Zanella R \& NoldiN JA (2009) Monitoramento de agrotóxicos em águas superficiais de regiões orizícolas no sul do Brasil. Ciencia Rural 39, 2383-2389.

Silva JTd, ScivitTaro WB, Souza ROd, Buss GL, Oliveira AD \& Rosa CMd Emissão de metano e óxido nitroso no período de entressafra do arroz irrigado sob diferentes manejos de solo e da cobertura vegetal. In: Anais 2013 XXXIV Congresso Brasileiro de Ciência do Solo, Florianópilos, Brazil, 4.

SiNGH JS, PANDEY VC \& SiNGH DP (2011) Efficient soil microorganisms: A new dimension for sustainable agriculture and environmental development. Agriculture, Ecosystems \& Environment 140, 339-353.

Siqueira Neto M, Venzke Filho SdP, Piccolo MdC, Cerri CEP \& CERri CC (2009) Rotação de culturas no sistema plantio direto em Tibagi (PR): I - Sequestro de carbono no solo. Revista Brasileira de Ciencia do Solo 33, 1013-1022.

SKROCH M \& LÓPEZ-HOFFMAN L (2010) Saving nature under the big tent of ecosystem services: a response to Adams and Redford. Conservation Biology 24, 325-327.

SOUNDARARAJAN K, Ho HK \& Su B (2014) Sankey diagram framework for energy and exergy flows. Applied Energy 136, 1035-1042.

Stein HH, Casas GA, Abelilla JJ, LiU Y \& Sulabo RC (2015) Nutritional value of high fiber co-products from the copra, palm kernel, and rice industries in diets fed to pigs. Journal of Animal Science and Biotechnology 6.

TABACHNICK BG \& FIDELL LS (2013) Using multivariate statistics - $6^{\text {th }}$ edition. Pearson Education Limited, Essex.

Thierfelder C, Chisui JL, GAMA M et al. (2013) Maize-based conservation agriculture systems in Malawi: Long-term trends in productivity. Field Crops Research 142, 47-57.

Tilman D, Cassman KG, Matson PA, Naylor R \& Polasky S (2002) Agricultural sustainability and intensive production practices. Nature 418, 671-677.

TUONG TP \& BOUMAN BAM (2003) Rice production in water-scarce environments. (eds JW Kijne, R Barker \& D Molden).

VAN GEERT P (2014) Dynamic modeling for development and education: from concepts to numbers. Mind, Brain, and Education 8, 57-73.

WANG L, WANG JG, LiTTLEWOOD J \& CHENG HB (2014) Co-production of biorefinery products from kraft paper sludge and agricultural residues: Opportunities and challenges. Green Chemistry 16, 1527-1533.

ZACHARIADIS T (2013) Gasoline, diesel and climate policy implications-Insights from the recent evolution of new car sales in Germany. Energy Policy 54, 23-32. 


\section{Supplementary Information}

A. Original Portuguese titles and internet links for the calls in the Box on page 12. Links accessed in 15 June 2017.

\section{Chickens die due to lack of feed in RS}

Original title: Frangos morrem por falta de ração no RS

Avicultura Industrial, 26 September 2002

http://www.aviculturaindustrial.com.br/imprensa/frangos-morrem-por-falta-de-racao-no-rs/20020926-0935020701

\section{Lack of corn raises hog price in $R S$}

Original title: Falta de milho eleva preço de suínos no RS

Suinocultura Industrial, 17 December 2007

http://www.suinoculturaindustrial.com.br/imprensa/falta-de-milho-eleva-preco-de-suinos-no-rs/20071217-

081007-3373

\section{Egg production will be affected by lack of maize in Brazil}

Original title: Produção de ovos será afetada pela falta de milho no Brasil

Jornal Gazeta Mercantil, 28 November 2007

http://www.seagri.ba.gov.br/noticias/2007/11/28/produ\%C3\%A7\%C3\%A3o-de-ovos-ser\%C3\%A1-afetada-pelafalta-de-milho-no-brasil

\section{Lack of corn and soybean for animal feed reaches critical level in RS}

Original title: Falta de milho e soja para ração animal atinge nível crítico no RS

Deputado Federal Jeronimo Gorgen, 31 July 2012

$\mathrm{http}: / /$ www.jeronimogoergen.com.br/index.php?option=com_content\&view=article\&id=670:falta-de-milho-esoja-para-racao-animal-atinge-nivel-critico-no-rs\&catid=39:-geral

\section{Planting the lesser corn area in 45 years, Rio Grande do Sul increases dependence on soy and put soil at risk \\ Original title: Ao plantar menor área de milho em 45 anos, Rio Grande do Sul aumenta dependência da soja e riscos para o solo \\ Noticias Agricolas, 15 September 2015 \\ https://www.noticiasagricolas.com.br/noticias/graos/161812-ao-plantar-menor-area-de-milho-em-45-anos-rio- grande-do-sul-aumenta-dependencia-da-soja-e-riscos-para.html}

\section{Industry dispute maize for chicken}

Original title: Indústria disputa milho para o frango

Gazeta do Povo, 14 December 2015

http://www.gazetadopovo.com.br/agronegocio/expedicoes/expedicao-avicultura/2015/industria-disputa-milhopara-o-frango-enqiomxosx $7 \mathrm{hdgs} 7 \mathrm{cs} 6 \times 31 \times \mathrm{xp} 2$

\section{High corn prices can affect poultry and pork sector}

Original title: Alta do milho pode prejudicar setor de aves e suínos

Sociedade Nacional de Agricultura, 21 January 2016

http://sna.agr.br/alta-do-milho-pode-prejudicar-setor-de-aves-e-suinos/

\section{RS farmers want corn financing to enlarge stocks}

Original title: Produtores do RS querem financiamento para milho para reforçar estoques Canal Rural, 01 February 2017

$\mathrm{http} / /$ www.canalrural.com.br/noticias/mais-milho/produtores-querem-financiamento-para-milho-para-reforcarestoques-65874 
B. Crop sequences and main activities in the farm systems monitored. $\mathrm{A}=$ Rice-Fallow; $\mathrm{B}=$ Rice-Soybean CT; C = Rice-Soybean MT; D = Ridges and Cattle; E = Ridges and Cover crops. Symbols: $+=$ nutrient entry (spread by tractors, aircraft or together at seeding crops); $\mathbf{0}=$ soil operations (excluding seeding); $\mathbf{x}=$ pesticide applications. Seeding and harvest processes are not symbolized but indicated by the start and end of coloured bars. Soil operations in D and E before Jan 2007 refer to the construction of the ridges.

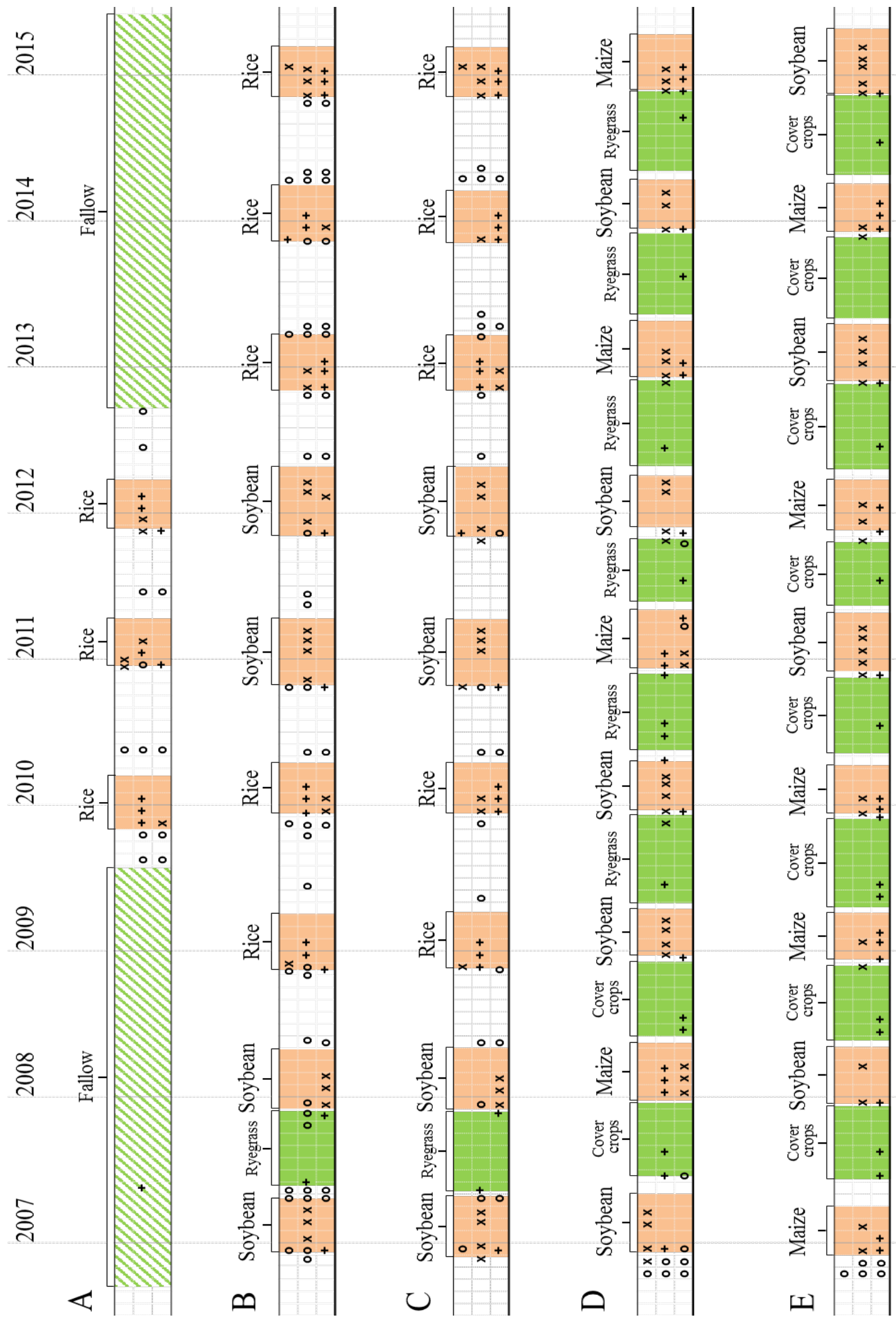


C. Daily-based weather conditions occurred during the experiment. $\mathrm{A}=$ minimum and maximum air temperature; $\mathrm{B}=$ precipitation; $\mathrm{C}=$ solar radiation.

D. List of machinery, their weight, operational yield, fuel consumption, embodied energy and energy consumed in the field operations (long-term experiments).

\begin{tabular}{lccccc}
\hline \multicolumn{1}{c}{ Machinery } & $\begin{array}{c}\text { Weight } \\
(\mathrm{kg})\end{array}$ & $\begin{array}{c}\text { Operational } \\
\text { yield } \\
\left(\mathrm{h} \mathrm{ha}^{-1}\right)\end{array}$ & $\begin{array}{c}\text { Fuel } \\
\text { consumption } \\
\left(\mathrm{L} \mathrm{ha}^{-1}\right)^{\mathrm{a}}\end{array}$ & $\begin{array}{c}\text { Embodied } \\
\text { energy } \\
\left(\mathrm{MJ} \mathrm{ha}^{-1}\right)\end{array}$ & $\begin{array}{c}\text { Energy } \\
\text { consumption } \\
\left(\mathrm{MJ} \mathrm{ha}^{-1}\right)^{\mathrm{b}}\end{array}$ \\
\hline Tractor 89 kW & 4650 & - & - & 35.6 & - \\
Tractor 55.2 kW & 2564 & - & - & 20.0 & - \\
Moldboard plough (0.4 m deep) & 1369 & 1.43 & 25.7 & 50.0 & 1245 \\
Disc plough (0.3 m deep) & 410 & 1.41 & 23.2 & 14.8 & 1099 \\
Hard Disc Harrow (0.3 m deep) & 2247 & 1.33 & 21.3 & 98.3 & 1095 \\
Light Disc harrow (0.1 m deep) & 760 & 1.00 & 12.0 & 24.2 & 594 \\
Levee plow & 500 & 0.80 & 11.2 & 25.5 & 552 \\
Laser-based soil leveler & 1500 & 0.67 & 9.3 & 11.4 & 450 \\
Bridge-type landplane & 1530 & 0.88 & 12.3 & 15.8 & 593 \\
Flex-chain harrow & 361 & 0.44 & 3.6 & 4.1 & 171 \\
Subsoil plow (30 cm deep) & 800 & 1.18 & 19.4 & 25.8 & 931 \\
Straw chopper (2.8 m width) & 735 & 1.11 & 17.8 & 20.9 & 852 \\
Rotary ditcher (0.15 m width) & 385 & 1.00 & 11.0 & 9.8 & 535 \\
Rotary ditcher (0.4 m width) & 310 & 0.40 & 4.4 & 3.2 & 213 \\
Light Roller & 910 & 0.44 & 3.6 & 4.4 & 172 \\
Hard roller (crimper roller) & 1520 & 0.57 & 5.7 & 24.3 & 299 \\
No-tillage seeder (in ridges) & 2540 & 1.28 & 17.7 & 101.1 & 934 \\
No-tillage seeder (in flat areas) & 2540 & 1.05 & 13.3 & 83.0 & 711 \\
Conventional seeder & 2165 & 1.00 & 11.9 & 67.5 & 633 \\
Seed and fertilizer spreader & 422 & 1.00 & 5.5 & 10.5 & 275 \\
Pesticide sprayer 600 L & 450 & 1.00 & 8.0 & 8.9 & 385 \\
Agricultural aircraft & 691 & 0.02 & 1.5 & 0.11 & 62 \\
Grain harvester (in ridges) & 9100 & 1.11 & 32.2 & 133.8 & 1568 \\
Grain harvester (in flat areas) & 9100 & 0.91 & 25.5 & 109.4 & 1242 \\
\hline a Ding
\end{tabular}

a. Diesel for tractors and combines; aviation gasoline for the aircraft operations.

b. Included energetic content of fuel consumed in each operation and energy embodied in the equipment and tractors. Extra 4.5\% added in account of lubricants and greases. Energy for labour is not included. 
F. Grain yields of maize, rice and soybean observed in the five cropping systems from $2007-$ 2015, expressed as a normalized value, using the regional average grain yield of the same year and crop as reference.

\begin{tabular}{|c|c|c|c|c|c|c|}
\hline \multirow{3}{*}{$\begin{array}{l}\text { Cropping } \\
\text { Season }\end{array}$} & \multirow{3}{*}{$\begin{array}{l}\text { Reference } \\
\text { values } \\
\left(\mathrm{kg} \mathrm{ha}^{-1}\right)^{\mathrm{a}}\end{array}$} & \multicolumn{5}{|c|}{ Cropping systems } \\
\hline & & $\begin{array}{l}\text { Rice- } \\
\text { Fallow }\end{array}$ & $\begin{array}{c}\text { Rice-Soybean } \\
\text { CT }\end{array}$ & $\begin{array}{c}\text { Rice- } \\
\text { Soybean MT }\end{array}$ & $\begin{array}{l}\text { Ridges and } \\
\text { Cattle }\end{array}$ & $\begin{array}{l}\text { Ridges and } \\
\text { Cover crops }\end{array}$ \\
\hline & & \multicolumn{5}{|c|}{ Grain yield relative to the respective reference value } \\
\hline \multirow{2}{*}{2007} & m 2039 (276) & - & - & - & - & $1.61(0.08)^{*}$ \\
\hline & s $1706(108)$ & - & $1.18(0.09)^{*}$ & $1.20(0.08)^{*}$ & $1.24(0.03)^{*}$ & - \\
\hline \multirow{2}{*}{2008} & m $2132(166)$ & - & - & - & $2.87(0.10)^{*}$ & - \\
\hline & s $2033(85)$ & - & $1.05(0.04)$ & $1.04(0.06)$ & - & $1.24(0.04)^{*}$ \\
\hline \multirow{3}{*}{2009} & m $2136(229)$ & - & - & - & - & $2.28(0.07)^{*}$ \\
\hline & r $7241(150)$ & - & $0.95(0.15)$ & $0.95(0.21)$ & - & - \\
\hline & s $2143(85)$ & - & - & - & $1.13(0.03)^{*}$ & - \\
\hline \multirow{3}{*}{2010} & $\mathrm{~m} 2553$ (218) & - & - & - & - & $2.47(0.06)^{*}$ \\
\hline & r 6791 (259) & $0.94(0.02)^{*}$ & $1.26(0.05)^{*}$ & $0.95(0.04)$ & & - \\
\hline & s 2195 (89) & - & - & - & $1.25(0.07)^{*}$ & - \\
\hline \multirow{3}{*}{2011} & m 2657 (358) & - & - & - & $2.69(0.06)^{*}$ & - \\
\hline & r 8052 (203) & $0.99(0.03)$ & - & - & - & - \\
\hline & s 2211 (113) & - & $1.01(0.07)$ & $0.93(0.06)^{*}$ & - & $1.08(0.06)$ \\
\hline \multirow{3}{*}{2012} & m $2730(465)$ & - & - & - & - & $2.57(0.18)^{*}$ \\
\hline & r $7498(115)$ & $0.90(0.06)$ & - & - & - & - \\
\hline & s $2399(133)$ & - & $0.84(0.06)$ & $1.20(0.04)^{*}$ & $1.26(0.04)^{*}$ & - \\
\hline \multirow{3}{*}{2013} & m 3665 (341) & - & - & - & $2.13(0.13)^{*}$ & - \\
\hline & r $7841(162)$ & - & $0.93(0.03)$ & $0.84(0.04)^{*}$ & - & - \\
\hline & s $2486(90)$ & - & - & - & - & $0.97(0.02)$ \\
\hline \multirow{3}{*}{2014} & m 3537 (335) & - & - & - & - & $1.70(0.08)^{*}$ \\
\hline & r $7443(185)$ & - & $1.02(0.14)$ & $0.93(0.04)$ & - & - \\
\hline & s 2407 (139) & - & - & - & $1.05(0.04)$ & - \\
\hline \multirow{3}{*}{2015} & m 3095 (328) & - & - & - & $3.28(0.10)^{*}$ & - \\
\hline & r $8103(172)$ & - & $0.99(0.04)$ & $1.06(0.02)$ & - & - \\
\hline & s 2297 (119) & - & - & - & - & $1.16(0.05)^{*}$ \\
\hline \multirow{3}{*}{$\begin{array}{l}\text { Crop } \\
\text { averages }\end{array}$} & $\mathrm{m} 2727(113)$ & & - & & $2.74(0.07)^{*}$ & $2.13(0.07)^{*}$ \\
\hline & r 7364 (78) & $0.94(0.02)$ & $1.03(0$. & $0.95(0$ & 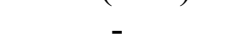 & \\
\hline & s $2215(40)$ & 10 & $1.02(0.03)$ & $1.09(0.04)$ & $1.19(0.02)^{*}$ & $1.11(0.02)^{*}$ \\
\hline \multicolumn{2}{|l|}{$\begin{array}{l}\text { System } \\
\text { Averages }\end{array}$} & $0.94(0.02)$ & $1.03(0.07)$ & $1.01(0.06)$ & $1.88(0.08)^{*}$ & $1.68(0.06)^{*}$ \\
\hline \multirow{2}{*}{\multicolumn{7}{|c|}{$\begin{array}{l}\text { a. Reference values: grain yield of maize }(\mathrm{m}) \text {, rice }(\mathrm{r}) \text { and soybean }(\mathrm{s}) \text { from the } 14 \text { municipalities near } \\
\text { to the experimental area. } \\
\text { b. Rice-Fallow included three additional cropping seasons calculated by Bayesian simulation, } \\
\text { corresponding to rice grain yields of } 7.2,7.7 \text { and } 7.8 \mathrm{Mg} \mathrm{ha}^{-1} \text {. }\end{array}$}} \\
\hline & & & & & & \\
\hline \multicolumn{7}{|c|}{$\begin{array}{l}\text { * Indexes followed by an asterisk indicate that the grain yield in the cropping system and cropping } \\
\text { season is significantly different from the respective reference value, at level of } \mathrm{W}<0.05 \text { (Wilcoxon } \\
\text { rank-sum test). }\end{array}$} \\
\hline
\end{tabular}


G. Internet links for the footnote in page 198 - General Discussion.

Topic: Headlines and titles for reports in some farmer-oriented media and magazines in RS state, Brazil, about the convenience of rice-soybean rotation in lowlands.

"Soybean, the salvation of rice fields"

http://www.jornaldopovo.com.br/anuarios/arquivos/pdf/7/anu28.pdf;

\section{"The perfect combination"}

http://www.revistarural.com.br/edicoes/item/6973-combinacao-perfeita

“Rice and Soybean, the gaucho's marriage"

http://revistagloborural.globo.com/Revista/Common/0,ERT335174-18283,00.html

\section{"(Soybean) on lowland".}

https://issuu.com/grupocultivar/docs/cultivar_162 
H. List of primary indicators constituting the Canonical Multivariate Discriminant Function. The same primary indicators were also used to calculate the Key Performance Indicators (KPI) presented in the General Discussion. The weight factors were used in this last calculation.

\begin{tabular}{|c|c|c|}
\hline KPI & Primary indicators & Weight \\
\hline \multirow[t]{12}{*}{ Environment } & Pesticide leaching potential & 0.165 \\
\hline & Nitrate leaching potential & 0.165 \\
\hline & Total pesticide applied & 0.085 \\
\hline & Active-ingredient per unit of grains & 0.085 \\
\hline & Field-toxicology (BRI) per unit of grains & 0.085 \\
\hline & Pesticide potentialy leached (ppb) per unit of grains & 0.085 \\
\hline & Total greenhouse (GHG) emissions & 0.055 \\
\hline & Overall carbon balance & 0.055 \\
\hline & GHG emitted per unit of food & 0.055 \\
\hline & GHG emitted per person fed per year & 0.055 \\
\hline & C-balance per unit of food & 0.055 \\
\hline & C-balance per person fed per year & 0.055 \\
\hline \multirow{9}{*}{$\begin{array}{l}\text { Land } \\
\text { productivity }\end{array}$} & Food produced per ha & 0.11 \\
\hline & Land-equivalent for biomass production $\left(\mathrm{m}^{2} \mathrm{~kg}\right.$ dry $\left.\operatorname{mass}^{-1}\right)$ & 0.11 \\
\hline & Grain production compared to regional averages $(\%)$ & 0.11 \\
\hline & People fed per year in energy basis & 0.17 \\
\hline & People fed per year in protein basis & 0.17 \\
\hline & Water-use efficiency for grains & 0.0825 \\
\hline & Water-use efficiency for other biomasses & 0.0825 \\
\hline & Radiation use-efficiency for grains & 0.0825 \\
\hline & Radiation use-efficiency for other biomasses & 0.0825 \\
\hline \multirow[t]{3}{*}{ Economics } & Net profits & 0.333 \\
\hline & Monetary risk & 0.333 \\
\hline & Money profitability & 0.333 \\
\hline \multirow{4}{*}{$\begin{array}{l}\text { Energy use- } \\
\text { efficiency }\end{array}$} & Overall energy-efficency & 0.25 \\
\hline & Energy balance & 0.25 \\
\hline & Fuels use-efficiency for grains & 0.25 \\
\hline & Nitrogen use-efficiency for grains & 0.25 \\
\hline \multirow[t]{3}{*}{ Labour } & Labour demand & 0.333 \\
\hline & Labour efficiency & 0.333 \\
\hline & Labour profitability & 0.333 \\
\hline
\end{tabular}

Normalization of indicators and calculation of KPIs follows the same approach as described in Chapter 3. Within a KPI, the normalized values of primary indicators in a same cell were multiplied by the respetctive weight. 


\section{References}

Aita C \& Giacomini S (2003) Decomposição e liberação de nitrogênio de resíduos culturais de plantas de cobertura de solo solteiras e consorciadas. Revista Brasileira de Ciencia do Solo 27, 601-612.

Chakma S, Ranjan A, Choudhury H, Dikshit P \& Moholkar V (2015) Bioenergy from rice crop residues: role in developing economies. Clean Technologies and Environmental Policy, 1-22.

EBELING J \& JENKINS B (1985) Physical and chemical properties of biomass fuels. Transactions of the ASAE (American Society of Agricultural Engineers) 28, 898-902.

ERIKSSON M \& AHLGREN S (2013) LCAs for petrol and diesel - a literature review. 36. Swedish University of Agricultural Sciences, Uppsala.

FUKSA P, HAKL J \& BRANT V (2013) Energy balance of catch crops production. ZemdirbysteAgriculture 100, 355-362.

García R, Pizarro C, Lavín AG \& Bueno JL (2014) Spanish biofuels heating value estimation. Part I: Ultimate analysis data. Fuel 117, Part B, 1130-1138.

Giuntoli J, Agostini A, Edwards R \& MARelli L (2015) Solid and gaseous bioenergy pathways: input values and GHG emissions. In: JRC Science and Policy Reports, Vol. 1a. (ed POOTE Union), 2015 edn, 232. Publications Office of the European Union, Luxembourg.

GuARIEnti EM, DuCA LdJAD, FontAneli RS \& ZANOTTO DL (2001) Chemical composition of main Brazilian winter cereals. Pesquisa Agropecuária Gaúcha 7, 7-14.

HADJIPANAYIOTOU M, ECONOMIDES S \& KOUMAS A Chemical composition, digestibility and energy content of leguminous grains and straws grown in a Mediterranean region. 1985 Annales de zootechnie, 23-30.

HEICHEL GH (1980) Assessing the fossil energy costs of propagating agricultural crops. In: Handbook of energy utilization in agriculture, Vol. 1. (ed D Pimentel), 27-33. CRC Press, Boca Raton, FL, USA.

KIŠ D, Sučić B, GuberaC V, VoćA N, RozMAn V \& UMANOvaC LS (2009) Soybean biomass as a renewable energy resource. Agriculturae Conspectus Scientificus 74, 201-203.

KitAni O, JungBluth T, PEART RM \& RAMDANi A (1999) CIGR handbook of agricultural engineering, Volume 5: Energy and biomass engineering. American Society of Agricultural Engineers (ASAE), St Joseph, MI, USA.

MEDEIROS LFS (2011) Avaliação da energia contida nos principais sistemas agrícolas e industriais da região médio norte do Estado de Mato Grosso - 2010. Master Thesis, Universidade Federal de Mato Grosso, Cuiabá, MT, Brazil.

PAtzeK TW (2004) Thermodynamics of the corn-ethanol biofuel cycle. Critical Reviews in Plant Sciences 23, 519-567.

PIMENTEl D (1974) Workshop on Research Methodologies for Studies of Energy, Food, Man and Environment: Phase I-II, (ed. C University). Cornell University, Center for Environmental Quality Management, Cornell, USA.

PIMENTEL D (2003) Ethanol fuels: energy balance, economics, and environmental impacts are negative. Natural Resources Research 12, 127-134. 
Portugal-Pereira J, Soria R, Rathmann R, Schaeffer R \& Szklo A (2015) Agricultural and agro-industrial residues-to-energy: Techno-economic and environmental assessment in Brazil. Biomass and Bioenergy 81, 521-533.

Restle J, Cerdótes L, VAZ FN \& BRONDANi IL (2001) Características de carcaça e da carne de novilhas Charolês e 3/4 Charolês $1 / 4$ Nelore, terminadas em confinamento. Revista Brasileira de Zootecnia 30, 1065-1075.

SAunders C, BARBer A \& TAYlor G (2006) Food Miles - Comparative energy/emissions performance of New Zealand's agriculture industry, (ed. AL University). Lincoln University. Agribusiness and Economics Research Unit., Lincoln, New Zealand. 


\section{Summary}

Agriculture in the lowlands of south Brazil is of strategic importance at national level, since it supplies around $80 \%$ of all rice, the main staple food consumed in Brazil. The prominence of these wetlands is so high that a mere change of $1 \%$ in rice production would be sufficient to affect the energy intake of 2.4 million Brazilians. In Rio Grande do Sul (RS), the southernmost state of Brazil, three million hectares of wetlands can be used for grain-based agriculture. Irrigated rice is the dominant crop in these wetlands, where the cereal is cultivated annually in 1.1 million ha. The rise in world food demand has led to an intensification in lowland rice production, with a concomitant increase of cultivation of soybean in these areas. Grain yield of irrigated rice increased from $3.5 \mathrm{Mg} \mathrm{ha}^{-1}$ in the 70 's to $5.3 \mathrm{Mg} \mathrm{ha}^{-1}$ in the 2000 's, attaining around $8 \mathrm{Mg} \mathrm{ha}^{-1}$ in the $2016 / 17$ cropping season. Thirty years (1970-2000) were needed to increase yields with $50 \%$, but more recently the same gain was realized in almost half of that time. Intensification has unequivocally increased rice productivity; however, large part of the recent gains is based on a higher use of external inputs. The environmental effects associated with this level of external inputs and issues connected with intensification, like weed resistance and soil-related limitations are exceeding acceptable levels. At same time, such high use of inputs also puts economic strains on farmers. The "commoditization" of crop production, symbolized by the large interest for soybean, has reduced the area of several other rainfed crops, thereby reducing the regional diversity in grain production. In short, farmers in the South Brazilian lowlands have contributed enormously to meeting the growing global demands for food but now there is need for them to be guided towards more diversified and sustainable production systems. Improving the rice-based systems and/or making these areas suitable for crops that do not tolerate flooding, could be a way to meet this challenge. To do this, it is important to better understand the mechanisms that drive sustainability in these systems. Such knowledge should be linked to the development and introduction of novel technologies for the management of these fields.

Overall, the scientific studies reported in this thesis deal with two main topics: (i) the assessment and understanding of current and alternative cropping systems for the southBrazilian lowlands, and (ii) the evaluation of two specific technologies. For the first topic, this thesis compiles the results of a long-term experiment (2006-2015), on which five distinct grainbased cropping systems in lowlands were assessed and compared. The study was conducted within an experimental station in south Brazil, where plots, with sizes ranging from 3 to 11 ha, 
were maintained during nine years. The comparison included the following systems: a) a simple monocrop rice (named 'Rice-Fallow', with 3 seasons rice -3 seasons fallow). This is the predominant model of rice production in the RS. Two more elaborated systems, based on ricesoybean rotation ( 2 seasons rice - 2 seasons soybean), cultivated either in b) conventional system ('Rice-Soybean CT'), or c) minimum-tillage ('Rice-Soybean MT'). Additionally, two novel systems, based on large ridges ( $8 \mathrm{~m}$ wide and $40 \mathrm{~cm}$ high in the center) conducted in notillage, on which maize and soybean were cultivated during the summer seasons, and d) pastures with livestock ('Ridges and Cattle'), or e) cover crops ('Ridges and Cover crops'), were cultivated in the winter seasons. In the ridge-based fields, the soil is shaped in a form that avoids water-saturation, thereby improving the conditions for growing of species which do not tolerate soil flooding. The ridges facilitate the adoption of Conservation Agriculture techniques, like the cultivation of cover crops during the cold season and no-tillage seeding. All five cropping systems were conducted as independent farms, and subjected to similar weather, the same initial soil conditions and a comparable quality of inputs, labour and machinery.

Besides this system assessment, the thesis also presents results from two other studies, proposed to improve relevant elements of specific rotation models. The first study evaluated the impact of changing the method of soil tillage after rice harvest, from the traditional combination of ploughing followed by harrowing to a faster and less energy-demanding method based on a knife-roller. The second study refers to the design and evaluation of an equipment invented and adapted on to the coulter disks of no-tillage seeders. The equipment improved the quality of soybean seeding and reduced weed seed germination, thereby contributing to weed management in fields conducted in no-tillage.

From these long-term and short-term evaluations, several indicators related to productivity, energy, environment, economy and labour were generated and evaluated. These results contribute to a better understanding of the cropping systems at micro (process) and macro (sustainability dimensions) level, and help to propose targeted and effective solutions to improve the sustainability of lowland cropping systems. The main results obtained in these studies are summarized in the various chapters of this thesis.

Chapter 2 - "The birth of a new cropping system: towards sustainability in sub-tropical lowland agriculture" describes and evaluates the performance of the five mentioned cropping systems. Three of these systems were based on rice production in a flat soil, whereas the other two involved rainfed crops, cultivated on large ridges. For grain production in the rice-based systems, no differences were observed in rice and soybean yield in comparison to the regional 
averages. However, soybean and maize cultivated in the ridges yielded on average $15 \%$ and $140 \%$ more than the regional standards. The traditional Rice-Fallow system required the lowest amount of energy, but it had also the lowest energy use-efficiency (i.e., yield per unit energy used) and the highest carbon-based environmental footprints, expressed as greenhouse gasses emitted per $\mathrm{kg}$ of food produced. In comparison to the rice-fallow system, the rice-soybean rotation systems presented an improved performance regarding the carbon-based footprints. Within the rice-soybean rotation, using minimum-tillage instead of conventional tillage increased the carbon incorporated into the soil as organic matter and improved the overall carbon balance. Most strikingly, the new ridge-based systems exhibited the most favorable values for many of the indicators. The more diverse rotation system, and particularly the extension of the growing season to the winter season, resulted in improvements in soil quality, biomass production and carbon sequestration into the soil. Water- and light- use efficiency of crop production were increased, while greenhouse gas emissions were reduced. Within the ridge-based systems, crop-livestock integration offered the best balance between food production and environmental preservation in terms of the carbon-based indicators.

Chapter 3 - "Use of a multi-criteria approach to evaluate five agricultural cropping systems in lowlands" extended on Chapter 2 delving deeper into aspects like energy, labour and economic efficiencies of the five cropping systems. The chapter also describes the creation of a framework consisting of Process Analysis (PA) and Key Performance Indicators (KPIs), used to systematically analyze the various cropping systems. To this purpose, cropping systems were decomposed in a series of technical processes (the PA step), consisting in chronological order of soil preparation, seeding, plant nutrition, irrigation, pest management, cattle management, harvest and transports. Beside these processes, a total of twenty-one indicators were generated. After standardization to a similar scale, the indicators were aggregated into five KPIs, representing five dimensions of sustainability (environmental aspects, land use-efficiency, economics, energy use-efficiency and labour). The Rice-Fallow system required less energy, presented the lowest costs and used less pesticides than the other cropping systems. However, this system appeared to be a non-land-saving system, as it produced the lowest amount of food per ha. A remarkable divergence, following the differences in soil management, was observed between the two rice-soybean rotations. Minimum-tillage saved energy and labour when compared to conventional-tillage, but such savings were substituted, in nearly the same proportion, by a higher consumption of herbicides. Both ridge-based systems stood out because of their high biomass production. However, when priority was given to keep winter cover crops 
intact instead of using it partly as winter feed for cattle, economic benefits nor immediate savings in fertilizer and pesticide use were obtained. The chapter presents robust evidence that the large-ridge system used with crop-livestock integration is a good option for sustainable intensification of the lowlands, especially when issues like soil quality and global warming are taken into account. The combination of Process Analysis and Key Performance Indicators proofed a valuable framework for this type of multiple assessment, and was able to detect and quantify small and large differences between cropping systems.

Chapter 4 - "A knife-roller effectively substitutes soil preparation by plough-and-harrow in lowland production systems" focusses on a technique to prepare soils after the harvest of irrigated rice, using a knife roller. After three cropping seasons of evaluation, the roller-based method showed it was not only faster, but also independent of weather conditions and more beneficial than the plough-based method in terms of energy, labour and monetary costs. Observations on soybean establishment and grain yield demonstrated that the alternative method performed as well as the conventional plough-based system. Benefits of the roller-based method were a $50 \%$ reduction in energy consumption for soil preparation, corresponding to a $22 \%$ increase in overall energy use-efficiency of soybean cultivated in rotation with irrigated rice in a flat lowland soil. Labour time and greenhouse gas emissions for soil preparation were reduced with $29 \%$ and $55 \%$, respectively. Next to these savings, the method can also be performed shortly after rice harvest, creating better opportunities for the introduction of cover crops or pastures in between rice and soybean. The knife-roller method showed to be a suitable alternative for seedbed preparation after irrigated rice in lowland production systems.

Chapter 5 - "Low disturbance and low speed seeding suppress weeds in no-tillage soybean" describes an invention which consists of an apparatus attached to the coulter disk of no-tillage seeders. This tool, named 'ski', reduces soil disturbance and keeps the straw layer in the right place during crop seeding in no-tillage fields. In this study, also one of the simplest ideas to minimize weed germination in no-tillage fields was tested: reducing the speed at crop seeding. Based on results of experiments conducted in two years and in distinct sites, the 'ski-seeder', in contrast to a non-modified seeder, showed to be able to reduce weed seed germination and to potentially reduce herbicide consumption in no-tillage fields. The new equipment led to a $56 \%$ reduction in in-row weed density in soybean and, on average, the modified seeder reduced weed biomass with $33 \%$. A lower planting speed $\left(1.3 \mathrm{~km} \mathrm{~h}^{-1}\right)$ reduced weed density with $50 \%$ and weed biomass with $40 \%$, in comparison with the highest seeding speed $\left(8.4 \mathrm{~km} \mathrm{~h}^{-1}\right)$. The research demonstrated that elements of an integrated weed management strategy, that are 
increasingly needed to make weed management more sustainable, can be found in relatively simple changes, like a modification to a seeder and a lowered seeding speed.

In Chapter 6, the General Discussion brings the results from the individual chapters into perspective and responds to the research questions presented in the introductory chapter. It starts summarizing the innovations offered in this thesis, discusses topics like land use and productivity in the wetlands, recapitulates some of the main findings and discusses some methodological issues. Next, a logical stepwise approach was presented in an effort to indicate the most sustainable system based on the experimental results. In summary, the introduction of the ridge-based system is an interesting and promising alternative to those agricultural fields in the lowlands which are kept fallow for a number of years in between the seasons with rice cultivation. The section finishes with an audacious exercise to establish a sustainability ranking (the 'Cumulative Benefit Index') of the cropping systems, contained in a single number, based on their performance with regard to land productivity, economics and environmental dimensions. The last part of the General Discussion presents and discusses the expected environmental, agronomic and economic impacts of two technologies unveiled in this thesis (the ridge-based concept and the knife-roller method for soil preparation), if adopted by a number of pioneer farmers in the lowlands in south Brazil. 



\section{Resumo}

A agricultura nas terras baixas do sul do Brasil tem uma importância estratégica a nível nacional, pois fornece cerca de $80 \%$ do arroz, principal alimento básico consumido no Brasil. A relevância destas áreas é tão alta que uma mera mudança de $1 \%$ na produção de arroz é suficiente para afetar a ingestão de energia (na alimentação) de 2,4 milhões de brasileiros por um ano. No Rio Grande do Sul, o estado mais ao sul do Brasil, três milhões de hectares em terras baixas estão estruturados para a irrigação por superfície e prontos para a prática da agricultura. Arroz irrigado é a cultura predominante nestas áreas, onde o cereal é cultivado anualmente em 1,1 milhão de ha. O aumento da demanda mundial de alimentos levou a uma intensificação na produção de arroz nas terras baixas, com um concomitante aumento no cultivo de soja nessas áreas. O rendimento de arroz irrigado aumentou de 3,5 $\mathrm{tha}^{-1}$ nos anos 70 para $5,3 \mathrm{t} \mathrm{ha}^{-1}$ na década de 2000, atingindo cerca de $8 \mathrm{t} \mathrm{ha}^{-1}$ na safra 2016/17. Trinta anos (19702000) foram necessários para aumentar a produtividade de arroz em 50\%, mas mais recentemente o mesmo ganho foi realizado em metade desse tempo. Sem dúvidas, a intensificação das lavouras aumentou a produtividade do arroz, no entanto, grande parte dos ganhos mais recentes é baseada no uso bastante elevado de insumos. Esta situação está alcançando um nível incompatível de sustentabilidade face às demandas atuais, além de fazer da agricultura uma atividade de alto risco para os agricultores, principalmente no ponto de vista econômico. Em paralelo, a "comoditização" da produção agrícola, simbolizada pelo grande interesse pela soja, reduziu a área de várias outras culturas, diminuindo assim a diversidade regional na produção de grãos. Os agricultores estão, de fato, atendendo a um mundo cada vez mais exigente em alimentos, mas a agricultura nas terras baixas pode ser orientada para ser mais diversificada e sustentável. Melhorar os sistemas baseados em arroz irrigado e reduzir as adversidades para espécies não tolerantes à inundação do solo parece ser uma escolha lógica para enfrentar esses desafios. Para isso, é necessário entretanto conhecer as bases da sustentabilidade dos sistemas de produção em terras baixas. Ao mesmo tempo, tecnologias específicas de manejo também são necessárias para que os agricultores melhorem seus sistemas de produção.

De modo geral, os estudos relatados nesta tese abordam dois tópicos principais: a avaliação e compreensão dos sistemas de cultivo atuais e alternativos para as terras baixas do sul do Brasil e a avaliação de duas tecnologias específicas para manejo do solo desses locais. Para o primeiro tópico, esta tese compila os resultados de um experimento de longo prazo 
(2006-2015), no qual cinco sistemas de cultivo foram comparados. O estudo foi realizado dentro da Estação Experimental Terras Baixas, da Embrapa, em Pelotas, RS, onde parcelas de grande tamanho, variando de 3 a 11 ha, foram avaliadas durante nove anos. A comparação incluiu os seguintes sistemas: a) arroz em monocultivo (chamado 'Arroz-Pousio', com 3 anos de arroz e 3 anos em pousio), modelo predominante de produção de arroz no RS durante a maior parte do tempo desse estudo. Dois sistemas com base na rotação arroz-soja (2 anos cada cultura), cultivados em b) sistema convencional ("Arroz-Soja PC"), ou c) cultivo mínimo ('Arroz-Soja CM' ). Além disso, dois novos sistemas, baseados em camalhões de base larga (8 $\mathrm{m}$ de largura e $40 \mathrm{~cm}$ de altura no centro) conduzidos em plantio direto, em que milho e soja foram cultivados no verão, e d) pastagens com gado ('Camalhão e Gado'), ou e) culturas de cobertura ('Camalhão e Coberturas'), foram mantidos no inverno. Nos camalhões, a microtopografia do solo é moldada de forma a evitar a saturação de água, o que melhora as condições de crescimento das espécies que não toleram encharcamento. O sistema facilita a adoção de técnicas típicas da agricultura conservacionista, como o cultivo de culturas de cobertura durante a estação fria e a semeadura direta. Os sistemas de cultivo foram gerenciados como minifazendas, submetidos ao mesmo clima, mesmas condições iniciais de solo e uma qualidade comparável de insumos, mão-de-obra e maquinário.

Além da avaliação dos sistemas de produção, a tese também apresenta os resultados de outros dois estudos, que abordam tópicos específicos nos sistemas de produção avaliados. $\mathrm{O}$ primeiro estudo avaliou o impacto da mudança do método de preparo do solo após a colheita de arroz, substituindo o sistema arado+grade+plaina por um método mais rápido e menos exigente em energia, baseado em um rolo-facas. O segundo estudo refere-se à avaliação de um equipamento inventado e adaptado aos discos de corte de semeadoras de plantio direto. Em nossos estudos, o equipamento melhorou a qualidade da semeadura de soja e reduziu a germinação de plantas daninhas, contribuindo assim para o manejo de invasoras em áreas de plantio direto.

A partir dessas avaliações de longo e curto prazo, vários indicadores relacionados à produtividade, energia, meio ambiente, economia e mão-de-obra foram gerados e avaliados. Esses resultados, de modo geral, contribuem para uma melhor compreensão dos sistemas de cultivo tanto a nível de processos quanto no nível das distintas dimensões da sustentabilidade, e ajudam a propor soluções para melhorar a sustentabilidade dos sistemas em terras baixas. Os principais resultados obtidos nestes estudos estão contidos nos vários capítulos, resumidos a seguir: 
Capítulo 2 - "O nascimento de um novo sistema de cultivo: em direção à sustentabilidade na agricultura em terras baixas subtropicais" descreve e avalia o desempenho dos cinco sistemas de cultivo. Três desses sistemas tem como cultura principal o arroz irrigado, em áreas planas, enquanto os outros dois sistemas envolvem o método de camalhões de base larga. Nos sistemas baseados em arroz-pousio e arroz-soja não foram observadas diferenças de produtividade em comparação com as médias regionais. No entanto, soja e milho cultivados nos camalhões de base larga renderam, em média, $15 \%$ e $140 \%$ a mais do que a média regional. O sistema arrozpousio exigiu a menor quantidade de energia, mas também apresentou a menor eficiência energética e as maiores pegadas ambientais para carbono, representadas pela quantidade de gases de efeito estufa emitidas por kg de alimento produzido. Em comparação com o sistema de arroz-pousio, os sistemas de rotação arroz-soja apresentaram um melhor desempenho em relação à pegada de carbono. Dentro da rotação arroz-soja, o uso do cultivo mínimo ao invés do plantio convencional melhorou o balanço de carbono do sistema. Os sistemas de cultivo baseados em camalhões de base larga exibiram os valores mais favoráveis para vários indicadores. Com um sistema de rotação diversificado, e particularmente, com a extensão do cultivo para o período de inverno, a qualidade do solo foi melhorada, houve grande produção de biomassa e sequestro de carbono no solo. A eficiência do uso da água e da radiação solar aumentou, enquanto as emissões de gases de efeito estufa diminuíram. Dentro dos sistemas baseados em camalhão de base larga, o sistema com integração lavoura-pecuária ofereceu o melhor equilíbrio entre a produção de alimentos e preservação ambiental.

Capítulo 3 - "Uso de uma abordagem multi-critérios para avaliar cinco sistemas de cultivo em terras baixas" aprofunda os estudos em aspectos como energia, mão-de-obra e eficiência econômica dos sistemas de cultivo anteriormente apresentados. O capítulo também descreve a criação de uma estrutura composta por Análise de Processo (AP) e Indicadores-Chave (ICs), utilizada para analisar sistematicamente os vários sistemas de cultivo. Para isso, os sistemas foram decompostos em uma série de processos técnicos (o passo AP), consistindo em ordem cronológica de preparo do solo, semeadura, nutrição, irrigação, manejo de pragas, manejo do gado, colheita e transportes. Além da avaliação desses processos, foram gerados um total de vinte e um indicadores. Após a padronização para uma mesma escala, os indicadores foram agregados em cinco indicadores chave, representando cinco dimensões da sustentabilidade (aspectos ambientais, eficiência no uso do solo, economia, energia e mão-de-obra). O sistema arroz-pousio exigiu menos energia, apresentou os menores custos e usou menos pesticidas do que os outros sistemas de cultivo. No entanto, este sistema demonstrou que não ajuda a reduzir 
(prevenir) a expansão da agricultura sobre área nativas, pois produz a menor quantidade de alimento por hectare dentre os sistemas avaliados. Dentre as duas rotações arroz-soja testadas, observou-se uma divergência interessante quanto ao manejo do solo. O cultivo mínimo economizou energia e mão-de-obra em relação ao plantio convencional, mas essas economias foram substituídas, na mesma proporção, por um maior consumo de herbicidas. Ambos os sistemas baseados em camalhões de base larga se destacaram pela alta produção de biomassa. No entanto, quando a prioridade foi dada para manter as culturas de cobertura de inverno intactas em vez de usá-la parcialmente como alimento para o gado, não se obteram retornos econômicos nas culturas, nem economia em fertilizantes ou pesticidas. Os resultados apresentados neste capítulo apresentam uma forte evidência de que o sistema de camalhões com integração lavoura-pecuária é uma boa opção para a intensificação sustentável das terras baixas, especialmente quando são consideradas questões como a qualidade do solo e aquecimento global. A combinação de Análise de Processos com Indicadores-Chave comprovou ser um método adequado para este tipo de avaliação múltipla, e foi capaz de detectar e quantificar tanto as pequenas e quanto as grandes diferenças entre os sistemas de cultivo.

Capítulo 4 - "Rolo-facas arrozeiro substitui o preparo do solo com arado e grade em sistemas de produção de terras baixas" foca em uma técnica para preparar o solo após a colheita de arroz irrigado, usando um rolo-facas. Após três anos em avaliação, o método baseado no rolo-facas mostrou que não foi apenas mais rápido, mas também independente das condições climáticas e melhor do que o método convencional (arado+grade) em termos de energia, mão-de-obra e custos financeiros. As observações tanto sobre o estabelecimento inicial da soja quanto o rendimento de grãos demonstraram que o método alternativo oferece a mesma condição para o desenvolvimento da cultura do que o sistema convencional. O método reduziu em $50 \%$ o consumo de energia para o preparo do solo, correspondendo a um aumento de $22 \%$ na eficiência geral do uso de energia na soja cultivada em rotação com arroz irrigado. O tempo de trabalho e as emissões de gases de efeito estufa relacionadas ao preparo do solo foram reduzidos em $29 \%$ e 55\%, respectivamente. O rolo-facas é usado logo após a colheita do arroz, criando melhores e mais rápidas oportunidades para a introdução de culturas de cobertura ou pastagens, entre o cultivo do arroz e da soja no próximo verão. Em síntese, o preparo do solo baseado no rolofacas arrozeiro demonstrou ser uma alternativa adequada para manejo do solo em pós-colheita de arroz irrigado em áreas de terras baixas.

Capítulo 5 - "Semeadura com baixo revolvimento de solo suprime ervas daninhas em soja em plantio direto" descreve uma invenção que consiste em um aparato em forma de esquis, 
conectado aos discos de corte de uma semeadora de plantio direto. Este equipamento reduz a movimentação de solo na linha de cultivo e mantém a camada de palha no lugar durante a semeadura de culturas em áreas de plantio direto. Neste estudo também foi testada uma das ideias mais simples para minimizar a germinação de ervas daninhas em plantio direto: reduzindo a velocidade de semeadura. Com base nos resultados de experimentos realizados em dois anos e em locais distintos, a semeadora adaptada mostrou ser capaz de reduzir a germinação de ervas daninhas, o que potencialmente pode reduzir o consumo de herbicidas em áreas de plantio direto. O novo equipamento reduziu em $56 \%$ a densidade de ervas na linha de cultivo de soja e a biomassa das ervas daninhas em $33 \%$. Semeando em baixa velocidade $(1,3$ $\mathrm{km} \mathrm{h}^{-1}$ ) reduziu-se a densidade de ervas daninhas em $50 \%$, e sua biomassa em $40 \%$, em comparação com a maior velocidade de semeadura $\left(8,4 \mathrm{~km} \mathrm{~h}^{-1}\right)$. Esta pesquisa demonstrou que estratégias integradas de manejo de ervas daninhas, cada vez mais necessárias para tornar o manejo mais sustentável, podem ser encontradas em mudanças relativamente simples, como uma modificação nas semeadoras ou adotando uma velocidade menor durante a semeadura das culturas.

No Capítulo 6, a Discussão Geral apresenta os resultados em uma nova perspectiva, e responde às questões de pesquisa apresentadas na introdução. A discussão inicia com um resumo das inovações apresentadas na tese, discute tópicos como o uso da terra e a produção agrícola nas terras baixas, recapitula alguns dos principais resultados e discute algumas questões metodológicas. Em seguida, uma abordagem lógica é apresentada, em um esforço para indicar, com base nos resultados experimentais, qual o 'melhor' sistema de produção. Em síntese, a introdução do sistema de camalhões de base larga é uma alternativa interessante e promissora para áreas de terras baixas que são mantidas em pousio. A seção termina com um audacioso exercício para estabelecer um ranking de sustentabilidade dos sistemas de cultivo, baseado em seu desempenho em termos de produtividade, economia e impacto ambiental. A última parte da Discussão Geral apresenta e discute os impactos ambientais, agronômicos e econômicos esperados de duas tecnologias apresentadas na tese (o uso de camalhões de base larga e o método de preparo de solo baseado no rolo-facas), caso esses métodos fossem adotados em parte das terras baixas no sul do Brasil. 



\section{Acknowledgments}

This thesis is not complete before I have expressed my sincere gratitude to all the people who, in one way or another, contributed to it. To avoid the sin of leaving someone out of this honorable list, I will however only personalize the names of my family members and the $\mathrm{PhD}$ supervisory team.

First, it would like to thank my family. My father Romeu (in memorian), my mother Zenide, my brother Sergiomar and his wife Fernanda. Needless to say how important all of you are in my life.

My sincere thanks to the people from Embrapa Clima Temperado, in Pelotas, Brazil, and the team of my former company, Fundacep/CCGL-Tec, in Cruz Alta, Brazil.

I have to say a sincere 'thank you' for the friendship and support from my colleagues in the Centre for Crop System Analysis group and the PE\&RC Graduate School, as well as to all the helpful staff from Wageningen University.

To my colleagues from Embrapa, their families, and other Brazilian compatriots who I met facing the same challenge to conquer a $\mathrm{PhD}$ at Wageningen University, my special affection.

To Lammert Bastiaans, my daily supervisor, and Niels P. R. Anten, my promotor, thank you for helping me to pursue my $\mathrm{PhD}$ track.

Finally, to my beloved wife Jossemar de Matos Theisen, who, patiently and with care, carries with her our first son: my sincere thanks for providing me strength, hope and love. 



\section{PE\&RC Training and Education Statement}

With the training and education activities listed below the $\mathrm{PhD}$ candidate has complied with the requirements set by the C.T. de Wit Graduate School for Production Ecology and Resource Conservation (PE\&RC) which comprises of a minimum total of 32 ECTS (= 22 weeks of activities)

\section{Review of literature (6 ECTS)}

- The potential and restrictions of agriculture in lowlands of Southern Brazil

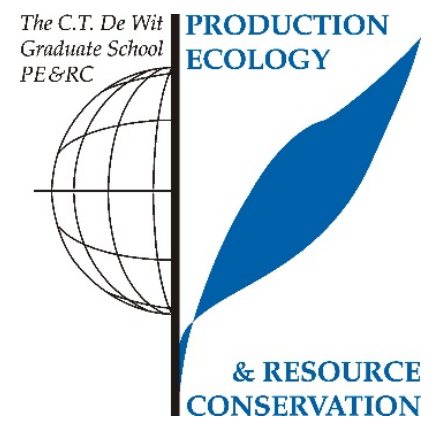

Writing of project proposal (4.5 ECTS)

- Strategies towards the sustainable intensification of agriculture in Lowland areas of Rio Grande do Sul, Brazil

\section{Post-graduate courses (5.9 ECTS)}

- Spatial sampling for mapping; PE\&RC/Sense (2015)

- Linear models; PE\&RC/Sense (2015)

- Generalized linear models; PE\&RC/Sense (2015)

- Multivariate analysis; PE\&RC/Sense (2015)

- Bayesian statistics; PE\&RC/Sense (2015)

- Sustainability analysis in food and biobased production; VLAG/Food Process Engineering (WUR, 2015)

\section{Invited review of (unpublished) journal manuscript (2 ECTS)}

- Planta Daninha: Chemical weed control; Weed ecology $(2014,2015)$

- Bragantia: Weed resistance to herbicides (2015)

- Experimental Agriculture: cropping systems - pest management (2016)

- Ciência Rural: Field crop management (2016)

- Weed research: crop \& weed ecology (2017)

\section{Deficiency, refresh, brush-up courses (1.5 ECTS)}

- Basic statistics; PE\&RC/Sense (2015)

\section{Competence strengthening / skills courses (3.4 ECTS)}

- Information literacy PhD including EndNote introduction; WGS (2014)

- Effective behaviour in your professional surroundings; WGS (2015)

- Techniques for writing and presenting a scientific paper; WGS (2016)

- Scientific publishing; WGS (2016)

PE\&RC Annual meetings, seminars and the PE\&RC weekend (2.4 ECTS)

- PE\&RC First year weekend (2014)

- PE\&RC Day: optimization of science: pressure \& pleasure (2014)

- PE\&RC Day: anthropogenic waste through the lens of an ecosystem (2015)

- PE\&RC Middle year weekend (2015)

- PhD Carousel; WGS (2016)

\section{Discussion groups / local seminars / other scientific meetings (4.5 ECTS)}

- Vegetation-Soil Interactions symposium (2014)

- CosSis seminar: science for impact: focus on enabling conditions (2014)

- Current Themes in Ecology: biodiversity research at the crossroads: understanding the long-term dynamics of ecosystems (2014)

- $\quad 2^{\text {nd }}$ and $3^{\text {rd }}$ Wageningen PhD symposiums; oral presentations $(2015,2016)$

- Participation, presentation and board of Sustainable Intensification (SIAS) discussion group (2015-2016)

\section{International symposia, workshops and conferences (8.8 ECTS)}

- $\quad 29^{\text {th }}$ Brazilian Congress of Weed Science; oral presentation; Gramado, Brazil (2014) $17^{\text {th }}$ European Weed Research Society Symposium; poster presentation; Montpellier, France (2015) $7^{\text {th }}$ International Congress of Weed Science; oral presentation; Prague, Czech Republic (2016) Workshop European Weed Research Society: physical and cultural weed control tools as moderators of crop weed interactions; poster presentation; Nyon, Switzerland (2017) 



\section{List of publications}

\section{Published Articles}

Theisen, G.; Silva, J.J.C; Silva, J.S; Andres, A.; Anten, N.P.R; Bastiaans, L. (2017). The birth of a new cropping system: towards sustainability in the sub-tropical lowland agriculture. Field Crops Research 212C pp. 82-94.

Theisen G.; Bastiaans L. (2015) Low disturbance seeding suppresses weeds in no-tillage soyabean. Weed Research 55, 598-608.

Ziska, L.H.; Gealy, D.R.; Burgos, N.; Caicedo, A.L.; Gressel, J.; Lawton-Rauh, A.L.; Avila, L.A.; Theisen, G.; Norsworthy, J.; Ferrero, A.; Vidotto, F.; Johnson, D.E.; Ferreira, F.G.; Marchesan, E.; Menezes, V.; Cohn, M.A.; Linscombe, S.; Carmona, L.; Tang, R.; Merotto, A. (2015). Weedy (red) rice: an emerging constraint to global rice production. Advances in Agronomy 129, 181-228.

Silva, J.J.C.; Theisen, G.; Idehara, S.J.; Silva, J.L.S.; Andres, A. (2015) Increasing the effectiveness of the land management after irrigated rice harvest. Revista Científica Eletrônica de Agronomia 28, 40-50.

Andres, A.; Theisen, G.; Teló, G.M.; Concenço, G.; Parfitt, J.M.B.; Galon, L.; Martins, M.B. (2015) Weed Management in Sprinkler-Irrigated Rice: Experiences from Southern Brazil. In: Advances in International Rice Research. doi:10.5772/67146 (Book Chapter).

Andres, A.; Concenço, G.; Theisen, G.; Vidotto, F.; Ferrero, A. (2013) Selectivity and weed control efficacy of pre- and post-emergence applications of clomazone in Southern Brazil. Crop Protection 53, 103-108.

Andres, A.; Concenço, G.; Theisen, G.; Galon, L.; Tesio, F. (2012) Management of red rice (Oryza sativa) and barnyardgrass (Echinochloa crus-galli) grown with sorghum with reduced rate of atrazine and mechanical methods. Experimental Agriculture 48, 587-596.

Andres, A.; Theisen, G.; Teló, G.M.; Concenço, G.; Galon, L. (2013) Weed resistance to herbic ides in rice fields in southern Brazil. In: Herbicides - current research and case studies in use. InTech (Book Chapter). doi: 10.5772/55947 (Book chapter).

Theisen G.; Bianchi M.A. (2010) Low-disturbance sowing: a weed management tool in corn. Planta Daninha 28, 93-102.

Andres, A.; Conçenco, G.; Schwanke, A.M.L.; Theisen, G.; Melo, P.T.B.S. (2009) Periods of weed interference in sorghum grown under lowland conditions. Planta Daninha 27, 229-234.

Theisen, G.; Andres, A. (2001) Interference of chlorpyrifos and methamidophos on selectivity and efficiency of acetochlor and nicosulfuron in maize. Agropecuária Clima Temperado 4(1), 19-26.

Theisen, G.; Vidal, R.A.; Fleck, N.G. (2000) Reduction of Brachiaria plantaginea infestation on soybean crop with black oat residues. Pesquisa Agropecuária Brasileira 35 (4), 753-756.

Theisen, G.; Vidal, R. A. (1999) Alexandergrass life-cycle is affected by black oat residues on the soil surface. Planta Daninha 17(2), 189-196.

Vidal, R.A.; Kruse, N.D.; Theisen, G. (1999) Yield components of soybean (Glycine max) influenced by straw level and weed infestation. Revista Brasileira de Agrociência 5(3), 178181. 
Vidal, R.A.; Theisen, G.; Fleck, N.G. (1999) Effect of ALS-inhibitors applied on soybean crop at the flowering stage. Revista Brasileira de Agrociência 5(2), 142-146.

Vidal, R.A.; Theisen, G. (1999) Straw on the soil surface affects the seed mortality of alexandergrass placed at two depths. Planta Daninha 17(3), 339-344.

Theisen, G.; Vidal, R.A. Alexandergrass (Brachiaria plantaginea) seed viability and soil cover with straw. (1999) Ciencia Rural 29(3), 449-452.

Theisen, G.; Vidal, R.A. ; Fleck, N.G. (1998) Interação dos herbicidas trifluralina e flumetsulan com o ph do solo. Pesticidas: Revista de Ecotoxicologia e Meio Ambiente. 8, 67-76.

Vidal, R.A.; Theisen, G.; Fleck, N.G.; Bauman, T.T. (1998) Straw in the non-tillage system reduces grass weed infestation and increases soybean yield. Ciencia Rural 28(3), 373-377.

\section{Submitted manuscripts}

Theisen, G.; Silva, J.J.C.; Bastiaans, L. A knife-roller effectively substitutes soil preparation by plough-and-harrow in lowland production systems. (2017). Experimental Agriculture

\section{Congresses, Symposia and Workshops (2013-2017)}

Theisen, G.; Bastiaans, L. Reducing in-row weed density in no-tillage systems through a modification of a no-till seeder. European Weed Research Society (EWRS) Workshop "Physical and cultural weed control tools as moderators of crop weed interactions". Nyon, Switzerland, April 2 - 5, 2017. p. 20.

Bastiaans, L.; Theisen, G. Does curative control level influence the effectiveness of cultural weed control? European Weed Research Society (EWRS) Workshop "Physical and cultural weed control tools as moderators of crop weed interactions". Nyon, Switzerland, April 2 - 5, 2017. p. 7.

Theisen, G.; Andres, A.; Teló, G.M.; Bastiaans, L. Parfitt, J.M.B.; Martins, M.B. Weed control in sprinkler irrigated dry-seeded rice. $7^{\text {th }}$ International Weed Science Congress. Prague, Czech Republic, June $19-25,2016$.

Andres, A.; Theisen, G.; Teló, G.M.; Martins, M.B.; Vargas, L. Interference of ACCAseinhibitor herbicides used to burndown of glyphosate resistant ryegrass (Lolium multiflorum L.) on irrigated rice cultivated in succession. $7^{\text {th }}$ International Weed Science Congress. Prague, Czech Republic, June 19 - 25, 2016.

Theisen, G.; Bastiaans, L. Weed management in no-till systems greatly benefits from lowdisturbance seeding. 17 $7^{\text {th }}$ European Weed Research Society Symposium "Weed management in changing environments" Montpellier, France, June 23 - 26, 2015.

Theisen, G.; Andres, A.; Bastiaans, L.; Parfitt, J.M.B. Dessecação em ponto de agulha no controle de plantas daninhas em arroz irrigado por aspersão [Chemical weed control in sprinkler irrigated rice]. XXIX Brazilian Congress of Weed Science. Gramado, Brazil, September 01 04, 2014. 


\section{About the author}

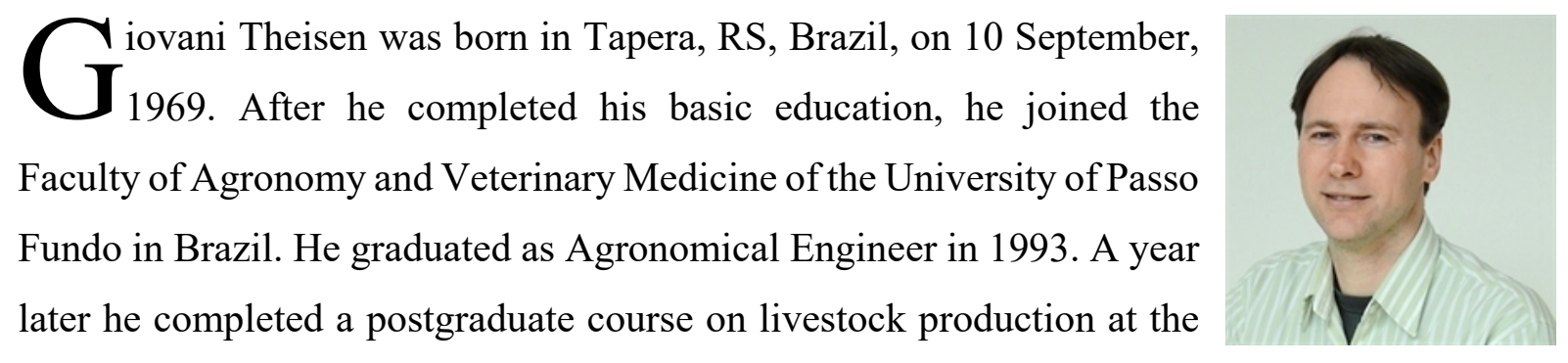

same University. In 1996, he joined the Faculty of Agronomy of the Federal University of Rio Grande do Sul, Porto Alegre, Brazil. In 1998, he obtained his MSc in Crop Production-Weed Science. Throughout his early-career, he worked as technical manager on a farmers' cooperative, as researcher in Monsanto Brazil, as researcher in the Fundacep/Fecotrigo in Cruz Alta, as teacher of crop production and weed management at the University of Passo Fundo, and as federal agricultural inspector in São Borja, Brazil and Santo Tomé, Argentina. He has experience in weed management, pesticide application technology, crop science and farming systems management. As a twelve-year-old up to the age of thirty, he also performed as a professional musician. Since August 2005, he is researcher at Embrapa, the governmental Agricultural Research Corporation of Brazil. For his research on the development of sustainable agriculture in the lowlands he received the 'Rice Scientist'-award in 2013, offered by the Federation of Associations of Rice Farmers of Rio Grande do Sul, Brazil. 


\section{Funding}

The research presented in this thesis was financially supported by the Brazilian Agricultural Research Corporation (EMBRAPA), Brasília, Brazil. 